Szegedi Tudományegyetem

Bölcsészettudományi Kar

DOKTORI DISSZERTÁCIÓ

LAMÁR ERZSÉBET

\title{
A KÜLÖNBSÉG EREJE ÉS A REPREZENTÁCIÓ PARADOXONA
}

NIETZSCHE METAFIZIKA-KRITIKÁJA

Málnási Bartók György Filozófia Doktori Iskola

Metafizika és metafizika-kritika alprogram

Prof. Dr. Csejtei Dezső, egyetemi tanár

A bizottság elnöke: Prof. Dr. Gyenge Zoltán, egyetemi tanár

Felkért bírálók: Dr. Schreiner Dénes PhD, egyetemi docens

Dr. Ullmann Tamás PhD, egyetemi docens

A bizottság tagjai: Dr. Czeglédi András PhD, egyetemi adjunktus

Dr. Fogarasi György PhD, egyetemi docens

Témavezető: Dr. Simon József PhD, egyetemi adjunktus

Szeged

2015 
„Elgondolni a reprezentáció bezáródását a tragikus elgondolását jelenti: nem mint a sors reprezentációját, hanem mint a reprezentáció sorsát. Alaptalan és ok nélküli szükségességét. És ez annak az elgondolását is jelenti, hogy miért végzetes az, hogy bezáródásában a reprezentáció folytatódik.”

/Jacques Derrida/ 


\section{Tartalom}

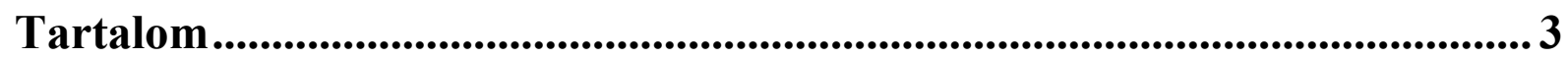

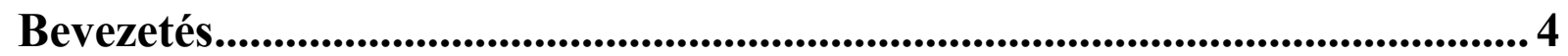

I. rész. Friedrich Nietzsche, a differencia filozófusa ......................................11

I. 1. Az „aktív differencia” mint folyamatos keletkezés: az ifjúkori mủvek .................................. 11

1. Exkurzus: Az örök visszatérés „fizikája”. Nietzsche és Boscovich ............................................ 35

I. 2. Az „aktív differencia” mint perspektíva és átváltozás: a „szabad szellem-trilógia” ................... 39

2. Exkurzus: Sematizmus-kritika és neokantianizmus: Nietzsche és Afrikan Spir ........................ 58

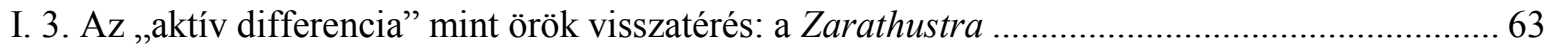

3. Exkurzus: Hatalom és élvezet: Nietzsche és Spinoza .............................................................. 74

I. 4. Az „aktív differencia” mint genealógia: a morálkritikák ……..................................................... 80

I. 5. Az „aktív differencia” mint minden érték átértékelése: A hatalom akarása .............................. 91

I. 6. Az „aktív differencia” mint dionüszoszi elem: az utolsó évek és az összeomlás ..................... 102

II. rész. Metafizika és kritika ..................................................................... 114

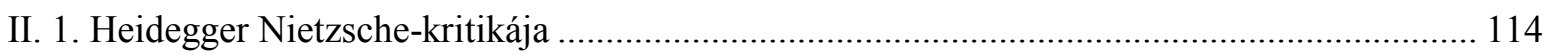

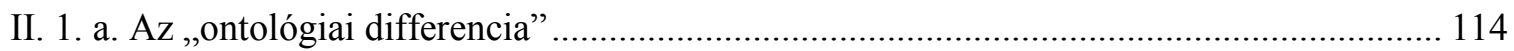

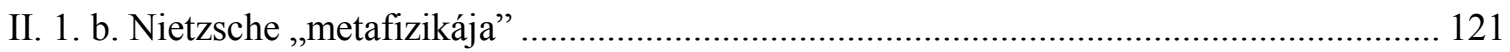

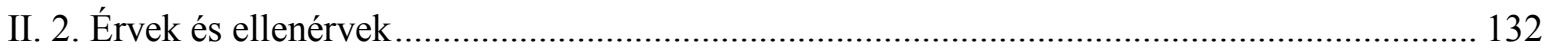

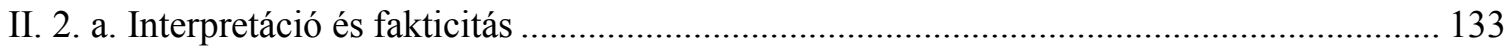

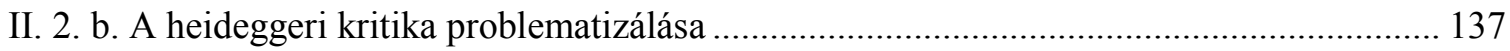

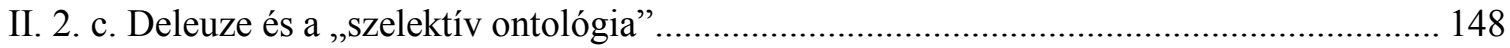

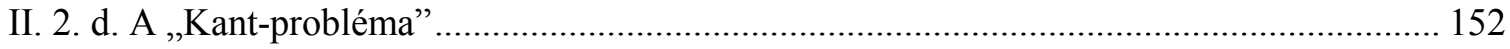

II. 2. e. Neokantianizmus, atom-elmélet és falszifikacionizmus .............................................. 160

II. 2. f. A differencia „radikális” elgondolhatatlansága: Jacques Derrida .................................... 169

Összegzés ............................................................................................................................ 180

Függelék ............................................................................................................................... 184

Irodalomjegyzék ............................................................................................ 188 


\section{Bevezetés}

A feltevés, melyből az itt következő értekezés kiindulni szándékozik, a következő: Nietzsche gondolkodása nem érthető helyesen anélkül, hogy tisztáznánk a kanti metafizikára, közelebbről a kanti ismeretelméletre, egészen konkrétan a „transzcendentális sematizmusra”"1 vonatkozó kritikája lényegét. Továbbmenve, azt is állítjuk, hogy egy átfogó igénnyel fellépő metafizika-kritika csakis reprezentáció-kritikára alapozva, a differencia egy radikális koncepciójaként lehetséges. Ez a több, mint száz évre visszatekintő Nietzsche-kutatásban alapvetésnek tekinthető kijelentés számunkra azonban mégis különös jelentőséggel bír, amennyiben két, hagyományosan egymással összeférhetetlennek tekintett filozófiai hagyomány, tudniillik, a neokantianizmus és a posztmodern (azon belül is a „radikális” differencia-filozófia) kibékítésének lehetőségét reméljük tőle. Utóbbi alatt a differenciának egy olyan, végletekig ,aktivizált” elgondolását értjük, amilyenről például Jacques Derrida beszél az „el-különböződés” kapcsán. Tisztában vagyunk vállalkozásunk merészségével, ezért is hangsúlyozzuk az itt következő vizsgálódások kísérleti jellegét. Ebből adódóan a szakirodalom-használat sok helyütt váratlannak tünhet, azonban az, hogy munkánk során a Nietzsche-értelmezés klasszikusai mellett nagyban támaszkodunk kortárs analitikus filozófusok meglátásaira, korántsem véletlen. Úgy véljük ugyanis, hogy a kontinentális filozófia nem csak, hogy többé már nem sajátíthatja ki a kontinentális filozófia interpretációjára való jogot, de amennyiben továbbra is így tenne, az elemzés fontos, új szempontjaitól fosztaná meg saját magát.

Munkánk során a következő három tézist kívánjuk igazolni: 1. Nietzsche metafizikakritikája, amely lényegét tekintve reprezentáció-kritika, a neokantiánus Kant-kritika talaján áll. 2. Az örök visszatérés és a hatalom akarása gondolatában kulmináló metafizika-kritika differencia-filozófiaként van kifejtve. 3. A fenti két állítás távolról sem mond ellent egymásnak, amennyiben a neokantiánus kriticizmus hatását egyrészt egy sajátosan nietzschei falszifikacionizmusban, ${ }^{2}$ másrészt pedig a hatalom akarása mint a hatóképes, „aktív”

\footnotetext{
${ }^{1} \mathrm{~A}$ transzcendentális sematizmus Kantnál az ítélőerő azon képességét jelenti, melynek segítségével az a szemléleteket tiszta értelmi fogalmak alá rendeli. Vö. TÉK 173-174. o.

${ }^{2}$ Megjegyzendő, hogy a „falszifikacionizmus” kifejezést munkánk során valóban sajátos, tudniillik a popperinél jóval radikálisabb értelemben használjuk majd. Úgy véljük ugyanis, hogy a Nietzsche által elöször, és a leghatározottabban A nem-morálisan fölfogott igazságról és hazugságról c. írásában elhangzott kijelentése, miszerint a szubjektum-objektum megfelelésként értett „helyes percepció” nem létezik, már a korai írások tekintetében felveti egy ilyen értelmezés lehetőségét. Erről, illetve a falszifikacionista értelmezésnek az életmü egészét érintő relevanciájáról a második részben szólunk majd részletesebben.
} 
differencia elvében és az örök visszatérés ezen „aktív” differencia által folyamatosan visszatérő keletkezésben tartott, radikálisan antireprezentacionalista gondolatában tudjuk felmutatni. Annak igazolására törekszünk, hogy a Nietzsche gondolkodásában kulcsfontosságú, ,aktív” differencia az a momentum, amely már eleve szükségtelenné teszi az értékellentétek bevezetését. Ennek a folyamatosan keletkező, és keletkezőként lényegileg „aktív” különbségnek a jelölésére praktikusnak tünik egy munkafogalom felvétele. Az „aktív differencia"” fogalma alatt, melyet a továbbiakban szakterminusként fogunk alkalmazni, az értékek átértékelésének állandó változásban lévő, rögzítetlen és rögzíthetetlen alapelemét értjük. Nézetünk szerint az ilyen értelemben vett „aktív differencia” mint a Nietzsche gondolkodásában a kezdetektől működő operatív és heterogén hajtóerő lehet az általában vett metafizika-kritika voltaképpeni alapja. Bár Nietzsche ebben a formában nem használta a kifejezést, ${ }^{3}$ látni fogjuk: mind a hatalom akarása, mind pedig az örök visszatérés koncepciójának kidolgozásakor kulcsfontosságú szöveghelyeken jelenik meg az „actio in distans" elve; munkafogalmunk ennek egyfajta parafrázisaként értendő. Amennyiben tehát mindezt igazolni tudnánk, úgy módunkban állna a differencia-filozófia létjogosultságával, tágabb értelemben pedig a metafizika-kritika lehetőségével szembeni aggályok közül legalábbis néhánynak az eloszlatása. Ehhez azonban megkerülhetetlennek tünik Heidegger Nietzsche-kritikájának kritikus újraolvasása, hiszen ha Heideggernek lett volna igaza Nietzsche filozófiája kapcsán, akkor az örök visszatérés gondolata egész egyszerüen nem lenne eléggé nyugtalanító, eléggé ,tragikus”. Ez esetben joggal vethetnénk Nietzsche szemére, hogy hatalmas a füst, de sehol a láng.

$\mathrm{Az}$ értekezés első részében Nietzsche filozófiájának „in nuce ${ }^{\text {,4 }}$ összegzésére vállalkozunk, egyrészt a kronológia lehetőség szerinti figyelembe vételével, másrészt az általunk meghatározónak tekintett ,aktív különbség” müködésének nyomán. Ezt követően a

\footnotetext{
3 A ,kanonizált” magyar fordítással rendelkező Nietzsche-idézeteket az említett fordítások szerint közlöm, az idegen nyelvü források esetében azonban a saját fordításomra támaszkodom, természetesen az eredeti szöveg lábjegyzetben történő feltüntetésével. Nietzsche szövegeinek esetében a Colli-Montinari-féle kritikai összkiadást (KSA) tekintem mérvadónak, az ifjúkori írásokat pedig a Historisch-Kritische Gesammtsausgabe (BAW) alapján idézem. Nietzsche leveleire hasonlóan, az elfogadott magyar fordítások egyikének megfelelően, vagy pedig a Colli-Montinari összeállítás digitalizált változata $(\mathrm{BVN})$ szerint hivatkozom. Utóbbi esetben a szövegben előforduló magyar nyelvü fordítások mindenhol tőlem származnak. (L. E.)

${ }^{4}$ dióhéjban; Nietzsche ezt a kifejezést használja $A$ bálványok alkonya című írása kapcsán egy 1888. októberében Georg Brandesnek írott levelében. Ld. Vö. Friedrich Nietzsche: Válogatott levelei. Ford., vál. Romhányi Török Gábor. Holnap Kiadó, Budapest, 2008, 236. o. „Ez az írásom a filozófiám in nuce - radikálisan, szinte a bünözésig...” / BVN-1888,1134. („Brief an Georg Brandes.”) „Diese Schrift ist meine Philosophie in nuce — radikal bis zum Verbrechen..."
} 
második, argumentatív részben már alkalmunk nyílik, úgymond, a dióhéjak „feltörésére”, vagyis Nietzsche filozófiájának a fentiekben kifejtett szempontok mentén történő, a metafizika kereteit szétfeszítő. reprezentáció-kritikán alapuló differencia-filozófiaként történő interpretációjára. Arra teszünk kísérletet, hogy Nietzsche filozófiájának meghatározó, konstitutív elemeként az „aktív differencia” fentiekben bevezetett fogalmát mutassuk fel, de oly módon, hogy mindeközben a határozott kritikai attitüd sem relativizmust, ne adj’ isten fatalizmust, sem pedig egy új alapokra helyezett metafizikát nem implikál. Ebben az esetben azonban a nihilizmus, vagyis a metafizikai gondolkodás mélyén munkáló, annak lényegéhez szervesen hozzátartozó önfelszámoló tendencia, kizárólag a metafizika egyfajta „,vigasz-

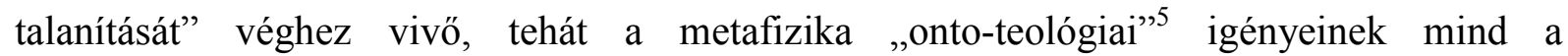
létjogosultságát, mind az általában vett lehetőségét alapvetően megkérdőjelező folyamatként értelmezhető. A hatalom akarása és az örök visszatérés ekkor nem a nihilizmus önfelszámoló jellegével, hanem az onto-teológiaként lelepleződő metafizikus gondolkodásmóddal szembeni ellenmozgásként válik meghatározóvá. Az „aktív differencia” pedig a metafizika-kritikát annak legvégső határáig: tudniillik az emberi gondolkodás és létezés, az úgynevezett „emberi lényeg" minduntalan a végességbe záródó, mégis a végtelen felé törekvő, tragikusan befejezett, de épp ilyen tragikusan befejezhetetlen karakterének igenléséig vivő alapmozgásként nyeri el voltaképpeni értelmét. A folyamatos átértékelés szükségszerüségét bejelentő kritika ismeretelméleti alapjainál pedig semmiképpen nem állhat verifikacionista érvelés, hanem csak olyan, amely az egyes gondolkodásmódok folyamatos gyanúba keverését, próbára tételét tekinti alapvetőnek, mely utóbbi, mint látni fogjuk, még a „tesztelhetőség” popperi kritériumát is további kérdezésnek vetné alá. Egy ilyen megközelítésnek azonban mindenekelőtt az idealizmussal, az oppozicionális gondolkodásmóddal és a metafizikai abszolútumok létének előfeltételezésére épülő erkölcsi világrenddel kell leszámolnia; Nietzsche számára ennek lehetőségét a kanti kritika kiteljesítése, közelebbről a transzcendentális sematizmus, és a magánvaló $\operatorname{dolog}^{6}$ kritikája teremti meg. A nietzschei filozófia itt következő rekonstrukciója során természetesen nem áll módunkban mindazon filozófusok, illetve filozófiák részletes tárgyalása, akik és amelyek,

\footnotetext{
${ }^{5}$ Heidegger szerint a metafizikus alaptendencia az „onto-teo-lógia”, melyben az „onto-lógia” és a „teo-lógia” egymást feltételezik, tehát a Létet és a létezőt egymással már mindig is szubjektum-objektum viszonyban levőként gondoljuk el. Minderről a Heidegger Nietzsche-kritikáját tárgyaló részben szólunk majd részletesebben. ${ }^{6}$ A magánvaló dolog meghatározását lásd itt: TÉK 3. § b) „A térbeli jelenségek transzcendentális fogalma ellenben kritikai figyelmeztetés arra, hogy egyáltalán semmi, ami a térben megjelenik, nem magánvaló dolog, sem pedig a tér nem formája a dolgoknak, mely nekik maguknak volna tulajdonuk, hanem hogy magukban a dolgok nem is ismeretesek elöttünk; amit pedig mi külső dolgoknak nevezünk, csak érzékiségünk képzetei, melyeknek formája a tér, melyeknek korrelátuma azonban, t.i. a magánvaló dolog, általa meg nem ismertetik $\mathrm{s}$ nem is ismerhető meg soha, de amellyel a tapasztalatban nem is törődünk."
} 
eltérő mértékben bár, de hatást gyakoroltak Nietzsche gondolkodására; így ezek közül mindössze azokat a hatástörténeti összefüggéseket jelezzük majd, melyek témánk szempontjából kiemelt jelentőséggel bírnak. Ilyen a preszókratikus filozófia, különös tekintettel Hérakleitoszra; Spinoza affektus-tana; a kanti transzcendentálfilozófia; Hegel dialektikus rendszere; valamint Roger Boscovich horvát természettudós-teológus-filozófus illetve Afrikan Alekszandrovics Spir neokantiánus gondolkodó egy-egy munkája. A második, argumentatív részben kiemelt szerepet kap az utóbbi két, a szakirodalomban ritkábban tárgyalt, ám annál érdekesebb szerző Nietzsche gondolkodására gyakorolt hatása. Előbbi atom-elmélete, utóbbi pedig a véges emberi megismerést jellemző „fundamentális antinómia” felmutatása révén kétségtelenül hozzájárultak az általunk a különbség „aktív” koncepciójaként azonosított tendencia kialakulásához, melyet jelen munka keretei között Nietzsche gondolkodásának meghatározó immanens hajtóerejeként kívánunk bemutatni, és amely nézetünk szerint az örök visszatérés gondolatának mint a nietzschei metafizika-kritika betetőzésének is alapjául szolgált.

Azt vizsgálva, vajon mit is jelent Nietzsche számára a tudás, Heidegger a Förster-Gast kompilációban 515-ös számmal jelölt, 1888 tavaszáról származó töredéket idézi: „Nem »megismerni«, hanem sematizálni, a káoszra annyi szabályszerüséget és formát erőszakolni, amennyire gyakorlati szükségleteink igényt tartanak". A tudás Nietzschénél eszerint sematizált kategóriák alkalmazása a káoszra a célból, hogy kezelhetővé tegyük azt. Heidegger úgy véli, a sematizmus gondolata mint olyan abból a metafizikus alaptörekvésből ered, mely a világ rendezett és strukturált reprezentációjára irányul és a létező és a Lét közti eredeti különbség elmosásához vezet, amennyiben a létezőt már eleve a Létben tételezi. ${ }^{8} \mathrm{~A}$ feltételezés, mondja, miszerint Nietzsche gondolkodása a metafizikus tradíció meghaladása vagy tagadása volna, abból a felületességből ered, amely azt, mellőzve a nyugati metafizika történetének vizsgálatát, „hérakleitoszinak”, „az akarat metafizikájának” vagy épp „,az élet filozófiájának" nevezi. Hiszen a kezdet természeténél fogva már eleve meghalad minden utána következőt, a múlt pedig, mint lényegi kibontakozás, megingat mindent, ami jelenlévőnek és bizonyosnak tünt - ez az a folytonosság, mely az örök visszatérés gondolatának mozgatórugója, és amely egyszersmind az általában vett metafizikai gondolkodás alapvető jövőbe-tartó jellegét, determinizmusát és esszencializmusát is meghatározza. Heidegger gondolatmenete a következő: ugyanannak az örök visszatérése a

\footnotetext{
${ }^{7}$ HA $515 . \S$ / KSA 13.333

${ }^{8}$ Vö. NI I:551-562.
} 
hatalom akarásának a beteljesülés pillanataként történő elgondolásában előlegeződik meg.Mindkét gondolat ugyanazt gondolja el; és kettejük ezen alapvető egységében a beteljesüléséhez közelítő metafizika kimondja a végső szót. A tény, hogy ez a lényegi egység mégis kimondhatatlan, megalapozza a tökéletes értelmetlenség korát, melyben a modernitás eljut önnön lényegéhez, tudniillik a nihilizmushoz. Egy ilyen beteljesülés azon átmenet lényegi sajátossága, amely átfogja mindazt, ami már elmúlt és egyszersmind előkészíti a jövőt. A metafizika valódi meghaladása eszerint csak a fentiekben leírt folyamat ellentettje lehetne, melynek során a létező (mint a létező totalitása) elveszíti a hatalmat a Lét igazsága felett. ${ }^{9}$ A nihilizmus, és vele a metafizikai gondolkodásmód meghaladása, állítja Heidegger, csak az ontológiai differencia, vagyis a Lét és a létező különbsége újra-elgondolása révén lehetséges, melyen belül szerinte a Lét bír ontológiai kitüntetettséggel. Ha azonban a nietzschei filozófiát differencia-filozófiaként értelmezzük, melynek kulcsmomentuma a folyamatos keletkezés „munkafogalmaként” felvett „aktív differencia”, akkor felmerül a kérdés: vajon nem lehetséges-e, hogy Nietzsche még Heidegger elött felismerte az ontológiai differencia jelentőségét? Úgy véljük, pontosan ez történt. Azonban, míg Heidegger az ontológiai differencia elfelejtéséről beszélt, addig Nietzsche számára, aki szerint „ez a világ a hatalom akarása és semmi más”, ${ }^{10}$ aligha lehet kielégítő bármifajta dualizmus vagy nominalizmus. Magától értetődően nem merészkedünk, nem merészkedhetünk olyan messzire, hogy Heidegger Nietzsche-kritikáját en bloctévesnek minősítsük. Mindössze annyit állítunk, hogy Heidegger saját filozófiáját tekinti a metafizika meghaladásának, és Nietzsche gondolkodását ebből a pozícióból bírálja - célunk e helyt nem több, mint a heideggeri kritika kritikus újraolvasása. Nem azt állítjuk tehát, hogy Nietzschének sikerült meghaladnia a metafizikát, hanem azt, hogy a metafizika-kritikát végső határáig vitte, és ezzel a metafizikus gondolkodásmódot, és az arra épülő erkölcsi világrendet jellemző általános élet-tagadást radikális igenléssé kristályosította át.

A posztmodern differencia-gondolkodás kezdetektől fogva a metafizika-kritika igényével lép fel, ez azonban véleményünk szerint csak abban az esetben lehet jogos, ha előbb szembenéz az általában vett „kriticizmus” nyitányaként értett kanti filozófiával, ezen belül pedig annak ismeretelméleti sarokkövével, a transzcendentális sematizmus elméletével. Úgy véljük, Nietzsche mindezt elvégezte; Heidegger azonban, épp azáltal, hogy a sematizmus-tant a fundamentálontológia megalapozásaként értelmezte, maga vitte véghez azt az onto-

\footnotetext{
${ }^{9}$ Vö. NI II:7-9.

${ }^{10}$ HA 1067. §
} 
teológiaként értett metafizikába való visszafordulást, melyet Nietzschén kért számon, mikor az örök visszatérés gondolatát a hatalom akarásának egyfajta ontológiájaként interpretálta. Deleuze a „szelektív ontológia”" ${ }^{11}$ elvében voltaképpen ugyanezt a gondolatmenetet dolgozza ki, azzal az eltéréssel, hogy az örök visszatérést elődlegesen anti-dialektikus, a különbséget kétszeres affirmációban igenlő gondolatként értelmezi. Deleuze filozófiája számunkra azért nem tünik igazán határozott differencia-gondolkodásnak, mert bár az önmagát igenlö különbséget az akaratnak a spinozai affektus-tanban megalapozott abszolút önmagátakarásával magyarázza, mégis mintha berekesztené annak voltaképpeni aktivitását, mikor felállítja az ,akarni=teremteni egyenletét”. ${ }^{12}$ Szempontunkból tehát Deleuze gondolkodása egyfajta „mérsékelt” differencia-filozófiának tünik.

Ezzel szemben Jacques Derrida írásai, a tőlük megszokott provokatív és váratlan módon, a különbség folyamatos mozgásban lévő, „el-különböződő” jellegének ${ }^{13}$ hangsúlyozásával tették szinte tapinthatóvá az általunk „aktív különbségnek” nevezett operatív erő kitüntetettségét Nietzsche gondolkodásában. Derrida A filozófiában újabban meghonosodott apokaliptikus hangnemröl ${ }^{14}$ címet viselő, Kant hasonló címü írására ${ }^{15}$ reflektáló szövegében az ,apokalipszist” valamilyen titok elsajátításában látja megnyilvánulni; az ,apokaliptikus mozdulat” tehát a titok leleplezését kell, hogy célozza. A kanti gondolatmenet szerint a filozófia halálát bejelentő eszmefuttatások maguk siettetik annak bekövetkeztét, méghozzá a néha az ostobaságig misztikus hangnemük révén, mellyel minduntalan valami „titok” lappangását sejtetik. Kant azonban, mint tudjuk, nem nagyon hitt a titkokban. Derrida szerint az ilyen hangnem mindig ,apokaliptikus”, tehát mindig „eszkatologikus”, amennyiben a „végsőről” szól, amely a meglévőből kirekesztett, hiszen azon „túl” van. Nem más ez, mondja, mint „a fogalmak ugrása az elgondolhatatlanba”. ${ }^{16}$ Derrida azonban úgy véli, éppen a kimondott és kimondatlan-kimondhatatlan közti határ illékonysága teszi veszélyessé a beszédet és a gondolkodást; ugyanis a határoltak

\footnotetext{
${ }^{11}$ Vö. Gilles Deleuze: Nietzsche és a filozófia. Gond/Holnap, Bp., 1999, 117. o. „Az örök visszatérésnek tehát kettős arculata van: egyfelől ő a változás univerzális léte, másfelől viszont a változás univerzális léte egyetlen valamivé-válásról állítható. Egyedül az aktívvá-válásnak van léte, mely a változás egészének a léte. [...] Az örök visszatérés fizikai doktrínaként a változás létét állítja. Ám mint szelektiv ontológia, a változásnak ezt a létét mint az aktívvá-válás »ön-állítását «állítja.” (kiemelés tőlem, L. E.)

${ }^{12}$ Deleuze (1999) 64. o.

${ }^{13}$ Vö. Jacques Derrida: „Az el-különbözödés.” Ford. Gyimesi Tímea. In: Szöveg és interpretáció. Szerk: Bacsó Béla. Cserépfalvi, Bp., 1991, 43-63. o.

${ }_{14}$ Jacques Derrida: „A filozófiában újabban meghonosodott apokaliptikus hangnemről.” Ford. Angyalosi Gergely. In: Jacques Derrida - Immanuel Kant: Minden dolgok vége. Ford. Angyalosi Gergely et al. Századvég, Bp., 1993, 34-93. o.

${ }^{15}$ Immanuel Kant: „A filozófiában újabban meghonosodott előkelő hangnemről.” Ford. Nyizsnyánszki Ferenc. In: Derrida-Kant (1993) 9-33. o.

${ }^{16}$ Derrida-Kant (1993) 51. o.
} 
szükségszerüen felcserélhetők. Az „el-különböződés” fogalmában Derrida ezen határ mozgékonyságát, a különbözés folyamatos, „különböződő” jellegét állítja, melynek értelmében a dolgok „lényege” csak a megragadásban: az elgondolásban és a kimondásban jut voltaképpeni létezéshez, ám ekkor már nem magán-, hanem számunkra-valóként. Látni fogjuk: Derrida számára a reprezentáció „kegyetlensége” abban áll, hogy természete szerint nem más, mint korlátozás.

Nietzsche filozófiájának az itt következő, reprezentáció-kritikára épülő, implicit módon ugyan, de annál célzatosabban a differencia egyfajta radikálisan „aktív”, és épp ezért valóban radikális koncepciója köré húzódó metafizika-kritikaként történő értelmezése révén a következő hipotézist kívánjuk tehát igazolni: Nietzsche filozófiája nem ragadt belül a metafizikán, de annak „meghaladását” sem jelenti. Úgy véljük, Nietzsche magát a metafizikakritikát vitte annak végső határáig, majd ott magára hagyta, éppen azért, hogy megmaradhasson totális kritikának.

Az ember természeténél fogva igyekszik megbarátkozni a végtelennel, ennek pedig a számunkra, véges lények számára egyedül elérhető módjának sokáig az tünt, ha pontonként rögzítve próbáljuk megismerhetővé tenni azt. Ez a felfogás vezetett a világ megismerő szubjektumra és megismerendő objektumra történő felosztásához, az értékellentéteken alapuló metafizikai gondolkodásmódhoz. Megpróbáljuk tetten érni, szavakba önteni a végtelent, és mintha egy szappanbuborékot akarnánk megragadni. Abban a pillanatban, ahogy sikerülne, ő maga el is tűnik, és nem marad más, csak szappan, víz és körülöttünk, bennünk, mindenütt maga a végtelen. A véges emberi létezés kegyetlensége épp ebben a momentumban rejlik, titkát épp ez a „mintha”, ez a „,veszedelmes talán”17 hordozza. A létezés egyedüli, rettentő „,igazsága” Nietzsche szerint nem más, mint hogy nincsen kezdet és vég, csak alakulás: ugyanannak az örök visszatérése, magának az örök visszatérésnek az örök visszatérése, keletkezetlen káosz, amely már mindig is kozmosz volt. Emberlétünk paradoxonára, a véges és végtelen határvidékén való létezésre csak radikális szkepszissel van értelme kérdeznünk. A véges ember a kérdezés végtelenségében érheti el maximális szabadságát, a filozófus, vagy inkább a gondolkodó ember csak a válaszok bizonytalanságában nem kételkedik, számára a valódi bizonyosság maga a kérdezés; a filozofálás így a végtelennek feltehető kérdések véget nem érö folyamata.

\footnotetext{
${ }^{17}$ Vö. JR 2. §
} 
Köszönettel tartozom a Málnási Bartók György Filozófia Doktori Iskola vezetőségének és oktatóinak, különösen témavezetőmnek, Simon Józsefnek, aki mindvégig koordinálta jelen disszertáció megírását, és akinek tanácsai, észrevételei nélkülözhetetlennek bizonyultak munkám során; Czeglédi Andrásnak, akinek támogatása, szakmai elhivatottsága és hozzáértése hatalmas inspirációt jelentett; valamint édesanyámnak - mindenért.

\section{I. rész. Friedrich Nietzsche, a differencia filozófusa}

\section{1. Az „aktív differencia” mint folyamatos keletkezés: az ifjúkori müvek}

Nietzsche 10 évesen, Händel Messiásának hatására komponálni kezd. 12 évesen, gyermekkori barátjával, Wilhelm Pinderrel közösen színdarabot ír Az olümposzi istenek címmel; a darabban ő játszaná Marsot, a háború istenét. Tizennégy éves korára saját bevallása szerint 46 költeményt írt; a következő tíz évben pedig kilenc önéletrajzi vázlata született. Kamaszkori olvasmányélményei: Szophoklész, Aiszkhülosz, Cicero, Vergilius, Theognis, Sallustius, Dante, a Genezis, az Edda-énekek és más északi sagák, Goethe, Schiller, Hölderlin, Jean Paul, Novalis, Byron, Shelley, Shakespeare; a klasszikusokat eredeti nyelven olvassa. Wagner zenéjével 1860-ban ismerkedik meg, de rajong Mozart, Haydn, Beethoven, Liszt, Schumann müveiért is. A filozófiával való első találkozást Hérakleitosz, Platón, Machiavelli, Rousseau, Kant és Hegel művei jelentették, még a pfortai évek alatt. ${ }^{18}$ Ennyit a „gyermekévekről”. Rüdiger Safranski szerint Nietzsche filozófiájának tétje a kezdetektől fogva az „irdatlannal” [das Ungeheure] való megbirkózás. ${ }^{19}$ Hogy ennek jelentőségét megértsük, nem árt sorra vennünk a német kifejezés jelentésárnyalatait: szörnyüséges, roppant, hatalmas, iszonyatos, hallatlan, felháborító - talán nem tévedünk nagyot, ha azt állítjuk, ennél aligha találhatnánk alkalmasabb kifejezést a Nietzschét foglalkoztató alapprobléma megnevezésére. Ez a probléma ugyanis nem más, mint maga az élet. Nietzsche számára az élet a kezdetektől fogva valami problematikusként mutatkozott: apját korán elvesztette, emberi kapcsolatait a kezdeti lelkesedés után mindig hatalmas kiábrándulás

\footnotetext{
18 Nietzsche olvasmányainak kapcsán lásd: Nietzsche’s Library. Comp. Rainer J. Hanshe. forrás: http://www.nietzschecircle.com/Pdf/NIETZSCHE_S LIBRARY.pdf

${ }^{19}$ Vö. Rüdiger Safranski: Nietzsche. Szellemi életrajz. Ford. Györffy Miklós. Európa, Bp., 2002, 7-12. (Ld. a fordító jegyzetét az 1. lábjegyzetben), 13. és különösen 45-69. o.
} 
követte; ez utóbbi még édesanyjával és húgával való kapcsolatára is igaz, de említhetjük a Wagner házaspárt, Erwin Rohdét, Paul Rée-t, Lou von Salomét is. Ifjúkora óta betegeskedett, harmincas évei elején már szinte teljesen vak, több napig tartó fejfájás- és hányásrohamokkal; az ezekkel járó, szinte elviselhetetlen fájdalmak kezelésére pedig ópiumot, hasist, klorálhidrátot, sőt, még valamilyen titokzatos jávai csodaszert is szedett. ${ }^{20}$ Miközben tehát szenvedett az élettől, legalább ennyire szenvedélyesen szerette is; az élet volt számára a legnagyobb kérdés és az egyetlen igaz szerelem. A Zarathustrában így vall: „Féllek közelről, megszerettetnek a messzeségek; menekülésed csalogat, közeledésed eltaszít - szenvedek, ámde nincs szenvedés, melyet ne viselnék szívesen teérted!" - majd kicsivel később így folytatja: „Eddig én daloltam neked, te boszorka, immár te légy az, ki - sikoltoz nekem! Táncolj, üvölts ütemre, ahogy korbácsom rád vág! Remélem, nem feledtem el a korbácsot. Nem hát!"21 Nietzsche számára élet, szenvedés és akarás elválaszthatatlanul összekapcsolódnak.

Úgy véljük, a nietzschei filozófia épp azért lehet az általában vett metafizika-kritika elégséges bázisa, mert reprezentáció-kritikán alapul, vagyis az értékek értékének problémáját, az egyáltalában vett metafizikakritika alapkérdését veti fel. ${ }^{22} \mathrm{Az}$ első fejezetben azt a gondolkodói utat igyekszünk rekonstruálni, mely Nietzschét előbb a kanti-schopenhaueri metafizikához, majd annak totális kritikájához vezette. Először a Hegel-kritika ösvényén Kantig, onnan tovább Schopenhauer és Wagner felé, velük vissza a görögökhöz, egészen a preszókratikusokig, ahol a filológiából végérvényesen filozófia, a metafizikából pedig metafizika-kritika lesz. Az 1876-ig terjedő első periódusnak központi jelentősége van az életmüben, ugyanis már a korai írásokban - illetve még hangsúlyosabban a jegyzetekben -, legalábbis implicit módon, benne rejlik Nietzsche gondolkodásának valamennyi meghatározó, részleteiben csak a következő években exponált eleme.

Legkorábbi, filozofikus hangvételü írásai még a pfortai időkből származnak; 1862 húsvétján született „Fátum és történelem”23 című dolgozata írásakor Nietzschében először szólal meg a kétely: mi van akkor, ha eddig igaznak hitt legfőbb értékeink mind a kereszténység előítéleteiből származnak? Ha leromboljuk mindezen előítéleteket, tudunk-e majd újakat teremteni? És ha végső soron minden érték a mi emberi kreációnk, akkor ki tudja,

\footnotetext{
${ }^{20}$ Nietzsche droghasználatáról lásd bővebben: Daniel Breazeale: „Ecce Psycho: Remarks on the Case of Nietzsche.” In: International Studies in Philosophy, XXIII/2, pp. 19-33., valamint David B. Allison: „Recipes for Ruin.” U.ott. pp. 35-54.

${ }^{21}$ Z III:2289-91, illetve 2322-25. „A másik táncdal.”

${ }^{22}$ Vö. Deleuze (1999) 13-23. o.

${ }^{23}$ BAW II. 54-59
} 
hány és hány világot teremtünk még? Isten nélkül elvész a cél is: csak mi maradunk és a végzet, melyben „esemény követ eseményt”, így szabad akaratunkat is csak eme végzet felől értelmezhetjük, annak „legmagasabb potenciáljaként”. ${ }^{24}$ Kereszténység-kritika, az idő és a történelem problémája, rombolás és teremtés szükségszerü összetartozása, végzet és akarat viszonya, sőt, mindezek mögött, alig hallhatóan talán még a nihilizmus gondolata is - későbbi legfontosabb témái kivétel nélkül kihallhatók a tizennyolc éves ifjú lelkesen-óvatos szavaiból. A következő pár évben filozófiatörténetet, archeológiát, grammatikát olvas, és már ekkor is foglalkoztatja a nevelés problémája; majd 1865-ben egy lipcsei antikváriumban ráakad Schopenhauer $A$ világ mint akarat és képzet c. müvére, ez a találkozás pedig kijelöli a Wagnerrel való 1876-os szakításig tartó időszak gondolkodásának irányát. A lipcsei években Bismarck elkötelezett híve; a nemzeti függetlenség eszméje később közös pont lesz a Wagnerrel való barátságban is, aki az 1849-es drezdai eseményekben való részvétele után menekült (többek között Liszt segítségével) Svájcba. Nietzschét ezidőtájt leginkább Kant és Schopenhauer filozófiája foglalkoztatta, különösen a látszat és a magánvaló dolog különbségének kérdése Kantnál, később pedig a kanti Ding an Sich és a schopenhaueri akaratfogalom viszonya. A következőkben az említett két problémára térnék ki röviden.

A már kritikai szellemmel „fertőzött” Nietzsche számára az 1865-ös Schopenhauerélmény jelentette a következő fordulópontot; barátait is az új „hitre” térítette, és 1866-tól kezdve Paul Deussennel, Carl von Gersdorffal, Hermann Mushackéval és Erwin Rohdéval állandó témájuk a schopenhaueri metafizika. A kanti és a schopenhaueri filozófia közti

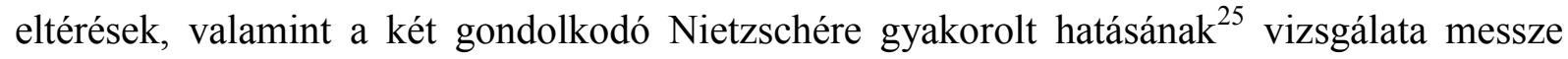
meghaladná jelen dolgozat kereteit, a fontosabbb ütközéspontokat azonban feltétlenül jeleznünk kell. Gersdorffnak 1866. augusztus végén írott levelében Nietzsche egy új, gondolkodására nézve igen jelentős felfedezésről számol be. Friedrich Albert Langét „igen felvilágosult kantiánusnak és természettudósnak" nevezi; a materializmus történetéről és jelenbeli relevanciájának kritikájáról ${ }^{26}$ szóló művét pedig a következőképp összegzi Gersdorffnak: 1. az érzékelhető világ szervezetünk produktuma., 2. saját látható (azaz testi) szerveink is képzetekként jelennek meg előttünk, tehát 3. szervezetünk valójában éppoly ismeretlen számunkra, mint a rajtunk ténylegesen kívül álló dolgok. Mindebböl pedig az

\footnotetext{
${ }^{24}$ Ld. u. ott

${ }^{25}$ Erröl bővebben lásd pl. Nick Land: „Art as insurrection: the question of aesthetics in Kant, Schopenhauer, and Nietzsche." In: Nietzsche and Modern German Thought. Ed. Keith Ansell-Pearson. Routledge, London-New York, 2002. pp. 240-256., illetve Alexander Nehamas: „Nietzsche: Writings from the early notebooks.” In: Introductions to Nietzsche. Ed. Robert B. Pippin. Cambridge UP, Cambridge, 2002, pp. 17-43.

${ }^{26}$ F. A. Lange: Geschichte des Materialismus und Kritik seiner Bedeutung in der Gegenwart. (1866) Neudruck in 2 Bänden: Suhrkamp, Frankfurt am Main, 1974.
} 
következik, hogy a dolgok ún.lényege, a kanti Ding an Sich nem csupán ismeretlen, de abban sem lehetünk biztosak, hogy saját tapasztalatunktól függetlenül rendelkezik-e egyáltalán bármiféle jelentéssel. Ezért kell a filozófusokat úgymond „szabadon engedni”, a művészetet pedig még a fogalmi kötöttségek sem korlátozzák. - Havalaki, hát Schopenhauer megfelel még egy materialista gondolkodó elvárásainak is! $!^{27}$ Nietzsche pedig lassanként filológusból filozófussá alakul: egyre inkább úgy véli, a filológia a maga avíttas, görnyedt háttal kutakodóelemezgető módján csak arra lehet alkalmas, hogy a filozófiát szolgálja, amely viszont elsődlegesen a művészet filozófiája, egészen pontosan a schopenhaueri-wagneri értelemben vett „müvész-metafizika”.

Mégsem mehetünk el szó nélkül egy hagyatékból előkerült, még a Wagnerrel való személyes találkozást megelőzően keletkezett szöveg mellett sem; ez pedig az ifjú schopenhaueriánus 1868. március-áprilisából származó, ${ }^{28}$ szarkasztikus hangvételü Schopenhauer-kritikája. Ebben kifejti, hogy az akarat-metafizika legalábbis négy oldalról mindenképpen támadható (persze hozzátéve, hogy neki magának eszébe sem jutna egy ilyen attak), nevezetesen: 1. az „akarat” formájában visszatérő kanti Ding an Sich Schopenhauernél is csak egy titokzatos kategória marad. 2. Az ,akarat”, amit tehát Schopenhauer a kanti 'x' helyére állít, voltaképpen csak költői intuíció eredménye, az erőltetett logikai levezetések még magát a szerzőt sem elégíthetik ki, nemhogy a kritikust. 3. Az akarat predikátumai is ebböl a bizonyítatlan bizonyosságból erednek; Schopenhauer egyszerủen csak az akarat világa és a reprezentáció világa közti ellentmondásból vezeti le őket, miközben nyilvánvaló, hogy a magánvaló dolog és annak képe között ilyen ellentmondásról nem beszélhetünk. 4. Mindebből következően tehát létezhet magánvaló dolog, de csak abban az értelemben, hogy a

\footnotetext{
${ }^{27}$ Vö. BVN-1866, 517. („Brief An Carl von Gersdorff.”) „Schließlich soll auch Schopenhauer noch erwähnt werden, an dem ich noch mit vollster Sympathie hänge. Was wir an ihm haben, hat mir kürzlich erst eine andere Schrift recht deutlich gemacht, die in ihrer Art vortrefflich und sehr belehrend ist: Geschichte des Materialismus und Kritik seiner Bedeutung für die Gegenwart von Fr. A. Lange. 1866. Wir haben hier einen höchst aufgeklärten Kantianer und Naturforscher vor uns. Sein Resultat ist in folgenden drei Sätzen zusammengefaßt: 1) die Sinnenwelt ist das Produkt unsrer Organisation. 2) unsre sichtbaren (körperlichen) Organe sind gleich allen andern Theilen der Erscheinungswelt nur Bilder eines unbekannten Gegenstandes. 3) Unsre wirkliche Organisation bleibt uns daher ebenso unbekannt, wie die wirklichen Außendinge. Wir haben stets nur das Produkt von beiden vor uns. Also das wahre Wesen der Dinge, das Ding an sich, ist uns nicht nur unbekannt, sondern es ist auch der Begriff desselben nicht mehr und nicht weniger als die letzte Ausgeburt eines von unsrer Organisation bedingten Gegensatzes, von dem wir nicht wissen, ob er außerhalb unsrer Erfahrung irgend eine Bedeutung hat. Folglich, meint Lange, lasse man die Philosophen frei, vorausgesetzt, da $\beta$ sie uns hinfüro erbauen. Die Kunst ist frei, auch auf dem Gebiet der Begriffe. Wer will einen Satz von Beethoven widerlegen, und wer will Raphaels Madonna eines Irrthums zeihen? - Du siehst, selbst bei diesem strengsten kritischen Standpunkte bleibt uns unser Schopenhauer, ja er wird uns fast noch mehr. Wenn die Philosophie Kunst ist, dann mag auch Haym sich vor Schopenhauer verkriechen; wenn die Philosophie erbauen soll, dann kenne ich wenigstens keinen Philosophen, der mehr erbaut als unser Schopenhauer."

${ }^{28}$ A Musarion-kiadásban a töredéket 1867 öszére datálják, lásd: MusA s. 392-401. „Fragment einer Kritik der Schopenhaucrischen Philosophie."
} 
transzcendencia világában bármi lehetséges, ami elgondolható, és ez a valami akár a magánvaló akarat is lehet. Schopenhauer tehát mégsem oldotta meg az individuáció problémáját. A probléma a következő: ami magára a Ding an Sich-re érvényes, az ugyanúgy érvényes három fő predikátumára (az egység, az öröklét értelmében vett időtlenség, az oknélküliség értelmében vett szabadság) is: hogy tudniillik a gondolkodás szféráján kívül értelmezhetetlenek. Nietzsche megjegyzi: nem véletlen, hogy Schopenhauer kifejezetten óvatosan kezeli az intellektus kérdését. Hiszen ha a magánvaló, vak akarat az, ami folytonosan reprezentálni kívánja önmagát, így hozva létre a képzetek világát, akkor a principium individuationis, az individuáció elve korábbi lenne, mint maga az intellektus. Az intellektus így vagy már eleve összetartozik a magánvaló akarattal, vagy pedig nem is létezhetne; mivel azonban kétségtelenül létezik; így nem lehet a reprezentáció eszköze, hanem csak magánvaló dolog, tehát akarat. ${ }^{29}$ Láthatjuk tehát, hogy itt Nietzsche elsősorban a magánvaló dolog és az akarat azonosságát cáfolja, továbbra is egyetért azonban az akaratmegtagadás lehetőségével; ekkor azonban még úgy véli, az alapvetően ösztön-jellegű világot az intellektusként értett akarat hajthatja uralma alá. ${ }^{30}$

Láthatjuk tehát: a metafizika-kritika igénye, bátortalan és vázlatos módon ugyan, de már az 1860-as évek vége felé jelentkezik Nietzschénél. Ennek egy újabb, eklatáns példája 1868-ban, egy tervezett disszertációhoz készített vázlata, melynek címe „Az organikus Kant utáni koncepciójáról”31 lett volna. Ebben „magyarázó teleológiának” nevezi a kanti rendszert, és azt állítja: „optimizmus és teleológia kéz a kézben járnak: mindkettő vitatja, hogy a célnélküliség valóban cél nélküli lenne. Általában véve: a teleológia elleni leghatásosabb fegyver: a cél-nélküliség igazolása."32 Kant gondolkodásának legfőbb hozadéka Nietzsche számára (is) kétségtelenül a filozófia antropológiai fordulata, mely az emberi végességet tekinti gondolkodásunk meghatározó elemének. Kant úgy vélte, az újkori filozófia veszélyesen eltávolodott az emberi tapasztalattól, így a metafizika reformján keresztül voltaképpen az emberi tudás lehetséges határait, és ezzel együtt az emberi lényeget kutatta. Transzcendentális fillozófiájának alapgondolata tehát a következő: maguk a dolgok létezésükben függetlenek tőlünk (magánvaló dolog), számunkra mégis jelenségekként

\footnotetext{
${ }^{29}$ Vö. BAW III.452-453. „Zu Schopenhauer.”

${ }^{30}$ Arról, hogy pontosan milyen természetű ez az uralom, Safranski így ír: ,a lényeget tekintve Nietzsche már ekkor is [e] hatalomakarással kísérletezik, mert számára a schopenhaueri akarattagadás nem tagadás, hanem felfokozott igenlés, amely a szellemi akaratnak a természetszerủ akarat fölötti győzelmeként értendő.” Safranski (2002) 32. o. (kiemelés tölem, L. E.)

${ }^{31}$ Ld. BAW III.459-464. „Die Teleologie seit Kant.”

32 BAW III. 459. („,Optimismus und Teleologie gehn Hand in Hand: beiden liegt daran das Unzweckmäßige zu bestreiten als etwas wirklich Unzweckmäßiges. Gegen Teleologie im Allgemeinen ist die Waffe: Nachweis des Unzweckmäßigen.”)
} 
adódnak, mely jelenségek rendje így nem azonos a dolgok saját rendjével. A metafizika tárgya tehát Kantnál a lehetséges emberi tudás és tapasztalat lehetősége, ahol a megismerés mindig érzékiség és értelem szintézisének eredménye, a következőképp: az érzékelés során az elmefüggetlen (magánvaló) dolgok felől érkező ingerek a tér és idő a priori formáiban válnak számunkra-való jelenségekké, melyeket aztán az öntudat a képzelőerő képessége révén szintézisben egyesít. Kant azonban úgy véli, a metafizika végső kérdéseire (a lélek halhatatlansága, a világegész természete, isten létezése) emberi álláspontról nem adható válasz, mert a „lélek”, a „világegész” és „Isten” nem adódnak számunkra-valóként, azaz jelenségként, tartalom és forma szintetikus egységeként, hanem csak magánvaló létezőkként. A kritikai filozófia központi tézise tehát, hogy a magánvaló dolgok [Ding an Sich] jelölik ki megismerésünk határait, amennyiben ezekről az elméleti ész nem képes kijelentéseket tenni. Nem meglepő tehát, hogy a kanti etika alapja szintén az erkölcsi törvény feltétlensége, a kategorikus imperatívusz tisztán formális parancsa. Az akarat szabadsága Kant állítása szerint az öntörvényadásra irányuló képességünket fejezi ki, amely nem puszta engedelmeskedés, hanem a kategorikus imperatívusz feltétlenségének felismerése révén adódó kötelességtudatból adódik. Az ember tehát minden tekintetben két világ polgára, a kettő közti kapcsolat megértéséhez Kant szerint a „célszerüség” fogalmának újradefiniálása szükséges, természetesen transzcendentális alapon. A teleológiai célszerüség alapvetően a két világnak az emberben történő egyesítésére irányul: az ember, mint kulturális lény, még alárendelt az okok és okozatok rendjének; morális lényként viszont már a természet voltaképpeni végcélja, aki így már nem is tartozik a természethez. Az ember legvégső lehetősége tehát, hogy olyan morális lénnyé váljon, aki képes a feltétlen törvény feltétlenségének felismerésére, azaz a megismerés határainak belátására és a hozzájuk való alkalmazkodásra. ${ }^{33}$ Nietzschének a schopenhaueri, illetve főként a kanti gondolkodással szembeni gyanakvása, mely már a filozófus Wagner-korszakát megelőzően felébredt, egyértelműen jelzi a metafizika-kritika explicit módon csak évekkel később kinyilvánított igényét.

1868. november 8-án végre megtörténik a várva-várt találkozás a Mesterrel (Nietzsche nevezte így a 31 évvel idősebb Wagnert), 1869 májusától 1872-ig Nietzsche húsznál is több alkalommal fordul meg Tribschenben. Eközben egyre kritikusabban kezd viszonyulni a filológus szakmához, pontosabban a szakma barbárjaihoz, akik szerinte nem képesek teremteni, mindössze a nagy szerzők müveinek elemezgetésére alkalmasak. Ö ezzel szemben a filológia kreatív, teremtő megújulásáért szállna síkra, méghozzá a nyelv zenével történő

\footnotetext{
${ }^{33}$ Vö. TÉK „Elöszó a második kiadáshoz.”; „Bevezetés.”
} 
átlelkesítése révén. Nietzsche filológiával, és általában véve a német műveltséggel szembeni kritikájának alapja az, hogy „túl német”, azaz eltávolodott a klasszikus, konkrétabban görög gyökerektöl. De kortársai többségétöl eltérően Nietzsche épp, hogy nem a tökéletes harmóniát, hanem az egymásnak ellentmondó erők konfliktusát látta a görög szellem lényegi elemének. Az egész görög kultúrát müvészinek tartotta, mert képes volt megjeleníteni ezt az alapvető ellentétet. Az antik emberkép az egyéniséget, annak kifejlesztését helyezi a középpontba, de mindez sohasem az egyén, hanem az állam, az egész érdekében történt. Egy 1870-ből származó jegyzetben így ír: „a görög művész sosem az egyénnek, hanem az államnak szánja műveit; és az állami oktatás, a maga részéről, nem volt egyéb, mint a műalkotás élvezete." ${ }^{34} \mathrm{~A}$ görög kultúrán belül, mind egyéni, mind pedig állami szinten hatalmas jelentőséget tulajdonít a versengésnek, a jó értelemben vett viszálykodásnak; szerinte ugyanis a humanitás nem az ember „természetes” adottsága, méghozzá azért, mert maga az élet is alapvetően kegyetlen: aki győz, az marad életben. „Minden tehetségnek küzdve kell kibontakoznia, így parancsolja ezt a hellén népi pedagógia [...] Ezért voltak az ókor emberei szabadabbak, mert céljaik közelebbiek és kézzelfoghatóbbak voltak. A modern embernek ugyanakkor mindig a végtelen állja útját..." 35 Az ifjú Nietzsche szemében azonban a görög szellem legnagyobb érdeme, melynek jelentősége jóval túlmutatott az állam és a nevelés helyes szervezésének kérdésein, a görög tragédia volt. Schopenhauer és Wagner híveként minden vágya volt megtalálni a szó és a zene valamilyen harmóniáját, természetesen a zenei elem túlsúlyával. Úgy vélte, maga a beszéd is elsősorban hangjai zeneisége révén rendelkezik kifejezőerővel, egyetlen haszna pedig az, hogy képes a zene közvetítésére. A modern opera épp azért rohan végromlása felé, mert a szöveg lassan teljesen elnyomja benne a zenét; a wagneri „zenedráma” ezzel szemben a görög tragédia új formába öntése. ${ }^{36}$

A görögség, Schopenhauer és Wagner által meghatározott gondolkodói korszak kétséget kizáróan legjelentősebb mủve $A$ tragédia születése a zene szelleméböl, ${ }^{37}$ melyet az

\footnotetext{
${ }^{34}$ KSA 7.168 „Der griechische Künstler richtet sich mit seinem Kunstwerk nicht an den Einzelnen, sondern an den Staat: und wiederum war die Erziehung des Staates nichts als die Erziehung Aller zum Genuß des Kunstwerks."

${ }^{35}$ Nietzsche, Friedrich: „A homéroszi versengés.” In: Ifjúkori görög tárgyú írások. Európa, Bp., 1988. 45-46. o.

${ }^{36}$ Vö. Friedrich Nietzsche: „A szó és a zene.” Ford. Petra-Szabó Gizella. In: Kultusz és áldozat: a német esszé klasszikusai. Szerk. Salyámosy Miklós, ford. Bart István et al. Európa, Bp., 1981. 303-316. o.(kiemelés tőlem, L. E.)

${ }^{37}$ Nietzsche maga is tisztában van azzal, hogy ez az alig füzetnyi méretü írás minden tekintetben élete és műve egyik fordulópontja: következménye a száműzetés a filológus szakmából, „véglegesítve” ezzel a filozófussá válást; Wagner teljes támogatásának elnyerése; de mindenekelött ez a tragikus, dionüszoszi gondolkodás első nyilvánosságra hozott hitvallása. Épp ezért, a Wagnerrel, Schopenhauerrel és a metafizikával való szakítás után sem fogja nézeteit teljes mértékben revideálni, de új előszót ír, és a mü címében is változást eszközöl (A tragédia születése avagy görögség és pesszimizmus), a lehetőségekhez képest áthelyezve ezzel a tartalmi hangsúlyt saját
} 
eredeti Előszóban a következő szavakkal ajánl Mesterének: „én a müvészetben ennek az életnek a legmagasabb feladatát, a voltaképpeni metafizikai tevékenységet látom, erről vagyok meggyőződve, annak a férfiúnak a szellemében, akinek e helyt mint nagyszerü úttörőmnek e könyvet ajánlani óhajtom.”38 Erre a mondatra még az 1886-os Önkritikakisérletben is hivatkozik, mondván: a mü legfőbb jelentősége nem „metafizikus” jellegében keresendő, hanem abban, mit ért a szerző metafizikán: a művészetet, méghozzá - már ekkor is - a morál ellenében. „Ez az egész művész-metafizika, mondható bár önkényesnek, meddőnek, fantasztának - lényege, hogy máris az a szellem árulkodik benne önmagáról, mely, vállalva minden kockázatát, egykor védekezni fog a létezés minden morális értékelése és értelmezése ellen. Talán először jelentkezik itt a »jón és rosszon túli« pesszimizmus... „39

A Tragédia színpadán elsőként Dionüszosz és Apollón jelennek meg: az őrület, a mámor, a szétszaggatottság istene, mellette pedig álom és valóság ura, maga a principium individuationis. A tragédia a két isten harmóniája: Dionüszosz a dividuum, aki szétszaggatottságában azonosul az „ős-eggyel”, melynek „képét azután zeneként hozza létre”, Apollón pedig megformálja, láthatóvá teszi ezt a zenét. Fontos azonban a dionüszoszi elem túlsúlya, ugyanis Dionüszosz az, aki „mámorában kimondta az igazat [...] Elveszett az individuum, minden határával és mértékével beleolvadt a dionüszoszi önfeledtségbe [...]A mértékfeletti igazságként lepleződött le, az ellentmondás, a fájdalomban fogant gyönyör hangjában a természet szíve nyilatkozott meg. ${ }^{" 40}$ Figyelemreméltó, milyen mélységesen antidialektikus itt Nietzsche: egyrészt Apollón önti szép formába Dionüszosz kegyetlen-mámoros katarzisát; az individuumban a dividuumot, miközben épp az ős-egytől való apollóni individuáció jeleníti meg a szétszaggatottság ősfájdalmát, melyet egyedül a dionüszoszi affirmáció képes fájdalomból örömmé változtatni. ${ }^{41}$ Azonban még ennél is értékesebb számunkra, amit Nietzsche a tragikus karról ír, mely voltaképpen a dionüszoszi lényeget hivatott apollóni módon közvetíteni, s ily módon a tragédia ős-jelensége

A metafizikai vigasz - amivel amint azt már itt kijelentem, bennünket minden igazi tragédia útnak bocsát -, hogy a jelenségek minden változékonysága ellenére a dolgok mélyein az élet hatalma, gyönyöre szétrombolhatatlan, e

teljesítményére. Nietzsche 1886-ban a stilisztikai és következtetésbeli hibáknál sokkal komolyabbnak tartja a kanti és schopenhaueri terminusok túlzott jelenlétét - miközben maguk az itt kifejtett nézetek amazok gondolkodásával „homlokegyenest ellentétesek” -, illetve a német kultúra túlértékelését. („A grandiózus görög problémát, úgy, amiként az kibomlott előttem, a legmodernebb dolgok belekeverésével voltaképpen tönkretettem! Hogy reményeket tápláltam ott, ahol mit sem lehetett remélni...”)

${ }^{38}$ TSZ 23. o.

${ }^{39}$ TSZ 13. o.

${ }^{40}$ TSZ 45. o.

${ }^{41}$ Vö. Deleuze (1999) 26-29. o. 
vigasz teljes világossággal a szatírkarban, természeti lények karaként ölt testet, akik mintegy elpusztíthatatlanul ott élnek minden civilizáció mögött, s a nemzedékek és népek történetének változásai közepette örökké ugyanazok maradnak. ${ }^{42}$

A görög tragédia esszenciális eleme tehát a kar, mely a metafizikai vigasz manifesztációja. A tragédia itt az általában vett müvészet paradigmájaként értendő, s mivel az élet maga is csak esztétikai jelenségként értelmezhető, a tragédia az élet paradigmája is, melynek alepeleme a metafizikai vigasz. De mit is jelent ez? - „hogy a jelenségek minden változékonysága ellenére a dolgok mélyein az élet hatalma, gyönyöre szétrombolhatatlan", vagyis hogy az apollóni látszat mögött mindig is ott van a dionüszoszi valóság: az élet rettentő őrülete, és vele együtt az őrület mámorában lelt gyönyör. Az ellentmondás igenlése ${ }^{43}$ végül átkristályositja magát az ellentmondást: különbséggé lesz, mely örökké visszatér, tehát mindig Ugyanaz. Félelmetes horderejü felismerés, mely azonban teljes mélységében valószínüleg magában a szerzőben is csak Zarathustra színrelépésével tudatosult. ${ }^{44}$ A tragédia dionüszoszi korának az euripidészi „attikai komédia” vetett véget. Euripidész Szókratész követe volt: felvitte a nézőt a színpadra, ezzel racionális, szükségképpen morális elemet csempészve a tragédiába; az „esztétikai szókratizmus” elve ugyanis, hogy a szépség előfeltétele az értelem Szókratésznél pedig már mindennek tudatosnak kell lennie, hogy jó lehessen. Szókratész óta ${ }^{45}$ az embert (a már nem dionüszoszi, hanem teoretikus embert) „csakis a lehulló lepel

\footnotetext{
${ }^{42}$ TSZ 65. o. (kiemelés tőlem, L. E.)

${ }^{43}$ Ld. KSA 7.219 „Honnan ered az ellentmondás élvezete a tragikus lényegben? Az ellentmondás, mint a dolgok lényege a tragikus cselekményben tükröződik vissza. Önmagából hozza létre a metafizikai látszatot, mely a tragédia révén válik elérhetővé. [...]Az individuum harca - az akarat alapja - a természet sóhaja.” / „Der Widerspruch als das Wesen der Dinge spiegelt sich in der tragischen Handlung wieder. Er erzeugt aus sich eine metaphysische Illusion, auf die es bei der Tragödie abgesehen ist. [...] Der Kampf der Individuen — Grund des Willens - Seufzer der Natur." (kiemelés tölem, L. E.)

${ }^{44}$ Brandenstein Béla szerint míg A tragédia születése a metafizikai vigasz művészetéröl, addig a Zarathustra már az evilági vigaszról, a nevetésről szól. Vö. Brandenstein Béla: Nietzsche. Szent István Társulat, Bp., 2002, 12. o.

${ }^{45}$ Nietzsche számára Szókratész valami olyasmit jelentett, mint Wagner, csak a személyes kötődés terhe nélkül: folyamatos és nyugtalanító szellemi kihívást, tagadhatatlan tiszteletet ember és mü iránt, és egy végérvényesen soha le nem zárt gondolatmenetet. Ld. erről Walter Kaufmann: „Nietzsche's Admiration of Socrates.” In: Journal of the History of Ideas. Vol. 9, No. 4. Oct. 1948, pp. 479-481, különösen p. 479. „Quite generally, Nietzsche distinguishes between (1) men whom he admires, (2) the ideas for which they stand, and (3) their followers. Only in terms of some such categories can one understand Nietzsche 's complex attitude toward Christ, Christianity, and Christendom. Similarly, Nietzsche admired Schopenhauer; respected but criticized Schopenhauer 's philosophy; and despised the followers who made his "debauches and vices [...] a matter of faith." (FW 99) Nietzsche admired Wagner and felt drawn to much of his music; but he abominated the ostentatiously Christian nationalists and anti-Semites who congregated in Bayreuth - Wagner's son-in-law (H. S. Chamberlain) and Nietzsche's sister are characteristic representatives-and Nietzsche 's critique of Wagner himself might be epitomized by saying that he accused Wagner of having become a Wagnerian. Nietzsche's fight againist Socrates thus takes two forms: denunciations of his epigoni and respectful criticisms of his doctrines. The critical period begins, characteristically, with a brief note in which "the pre-Socratic and the post-Socratics (Nachsokratiker) " are contrasted and the increasing concern with happiness after Socrates is deplored. (VI, 104) The attack on the epigoni is also foreshadowed by the conception of Alexandrian culture which we find in the closing pages of The Birth of Tragedy, but Nietzsche certainly distinguished between the Lebensphilosoph
} 
gyönyörködteti”, az igazság akarása hajtja, de a megismerés kígyója végül mindig „maga köré tekeredik és a saját farkába harap" ${ }^{\text {46 }}$ - ám mielőtt ez bekövetkezne, és az élet elveszítené a célját, a müvészet (vagy a metafizika) rendszerint időben érkezik, hogy a fájó igazságot újra beborítsa a látszatok fátylával. A kérdés csak az, hogy Nietzsche meddig éri be ezzel a magyarázattal. $^{47}$

Gilles Deleuze a nietzschei gondolkodást differencia-filozófiaként interpretálja, és hangsúlyozza annak radikálisan anti-dialektikus jellegét. ${ }^{48}$ Bár, mint látni fogjuk, nem áll módunkban egyetérteni Deleuze elemzésének minden részletével, az mindenestre kétségbevonhatatlannak tünik, hogy Nietzsche gondolkodásában, különösen annak korai szakaszában, meghatározó szerepet játszik a Hegel filozófiájára való reflexió, majd az azzal való igen határozott polémia. A tragédia születéséről maga Nietzsche is azt vallja, hogy még „botrányosan Hegel-ízü”, 49 és bár Apollón és Dionüszosz szimbiózisa valóban erősen dialektikus jellegü, a hegeli és nietzschei gondolkodás alapstruktúrájának lényegi ellentéte már ekkor megmutatkozik; mégpedig éppen a különbség-problematika kapcsán. Hegel azt állítja, hogy az ész a jelenség közvetítése révén képes a lényeg megismerésére. Míg tehát Kantnál a szubjektum csak a jelenséget képes megismerni, amely puszta látszatként abszolút különbözik a dolog lényegétől, ${ }^{50}$ a hegeli dialektikus ész az önmagához való visszatérésben az érzéki szemlélettől a dolgok lényegének megismeréséhez jut el. Ez pedig egyedül úgy lehetséges, hogy az érzéki tapasztalatban, vagyis a szemléletben már eleve a lényeg, azaz

Socrates and the mediocrity who knows only the palest pleasures and lacks any conception of life or passion. Socrates, while definitely a decisive "turning point" in history is the very embodiment of Nietzsche 's highest ideal: the passionate man who can control his passions." (kiemelések tölem, L. E.)

${ }^{46}$ Vö. TSZ 91-127. o.

${ }^{47}$ A müvész-metafizika és a pesszimista konklúzió között jellegzetesen nietzschei, és nagyon is találó folyamatábrát rajzol fel Raymond Geuss. Nietzschének abból a kijelentéséből indul ki, mely szerint „a létezés és a világ csakis esztétikai jelenségként nyeri el örök igazolását" (TSZ 54. o.). Elöször is azt kell tisztáznunk, mondja Geuss, mit is jelent itt az igazolás [Rechtfertigung]; végül arra jut, hogy ez a nietzschei értelmezésben félúton lehet a puszta dionüszoszi mámor, illetve a szókratészi argumentatív módszer között. Ha viszont a Tragédia-könyv valóban egy kielégítő esztétikai teodícea akar lenni, meg kell mondani, ki hozza a fenti ítéletet, melyen a teodícea alapul. Nietzsche egy helyütt Homéroszra vonatkozik, akinél a világ létezése azáltal jogosult, hogy kellemes látványt nyújt az olümposzi istenek számára. Geuss szerint Nietzsche az Önkritika-kísérlet második szakaszában „,müvész-metafizikáról” beszél, ennek a homéroszi gondolatnak egyfajta „,szekularizált változatát" állítja. Az individuációt megelőző ős-Egy maga is müvész, a hérakleitoszi gyermek-isten, akiben teremtés és rombolás gyönyöre egy és ugyanaz. Geuss a keresztény teodíceák és a nietzschei közti különbséget abban látja, hogy elöbbiek esetében a teodícea (vagyis Isten - és vele együtt a túlvilág - létének igazolása), az optimizmus (megéri élni) és az affirmáció momentuma szorosan összekapcsolódik, míg mi, egész világunkkal egyetemben csak tünékeny illúziók vagyunk, arra kárhoztatva, hogy mindennek tudatában is legyünk. A dionüszoszi világnézet pesszimizmushoz vezet, mely legyőzhető ugyan, de nem az optimizmus, hanem az affirmáció révén. Vö. Raymond Geuss: „Nietzsche: The Birth of Tragedy.” In: Introductions to Nietzsche. Ed. Robert B. Pippin. Cambridge UP, Cambridge, 2002, pp. 44-66.

${ }^{48}$ Ld. Deleuze (1999) 23-26. o.

${ }^{49} \mathrm{EH}$ 66. o.

${ }^{50}$ Vö. TÉK 8. § 
maga a szellem jelenik meg, amely így a megismerési folyamatban előbb elidegenedik önmagától, majd pedig visszatér önmagához; az „abszolút szellem” antropomorf jellegének tételezése révén az igazság egyszerre lehet szubsztanciája és szubjektuma a megismerési folyamatnak. Hegelnél a dialektikus folyamat az elvonttól a konkrét felé tartó kibontakozás folyamata; és nem pusztán gondolkodásunk, hanem létezésünk is ezt a szabályt követi. ${ }^{51}$ „Az igaz az egész. Az egész azonban csak a saját fejlődésében beteljesült lény. Azt kell mondanunk az abszolútumról, hogy lényegében véve eredmény, hogy csak a végén igazi". 52 Hegel dialektikája a metafizikus gondolkodás meghaladásának kísérleteként értelmezhető, amennyiben az utóbbi a változatlan, statikus valóságot írja le, míg a dialektika a lét és az értelem mozgását ábrázolja; a dialektika a valóság és a megismerés alaptörvénye. A tézisantitézis-szintézis elve szerint tehát az ellentétek végül abszolút egységgé oldódnak, így ellentmondásról csak a részek, nem pedig az egész tekintetében beszélhetünk; az ellentmondás maga sem konkrét létező, hanem pusztán elvont fogalom. Hatalmas jelentőséggel bír annak belátása, hogy a negatív voltaképpen nem önmagában negatív, csak funkcionálisan, negációként; a tagadás mindig a lényeg tagadása, mely a pozitívumhoz való visszatérésben „megszüntetve megőrződik”. (Hegel az „Aufhebung” kifejezéssel jelöli azt a jelentés-hármasságot, mely egyszerre fejezi ki ezt a két mozzanatot, valamint a tudatnak az „abszolút tudás”, illetve a szellemnek az „abszolút szellem” egységformájára történő felemelkedését a szintézisben. ${ }^{53}$ ) A hegeli rendszerben tehát az elvont lét [Sein] a „keletkezésben” [Werden] alakul konkrét létezéssé [Dasein], azaz elvont, magasabb szintü létté; a dialektikus folyamatban tehát a lét és a semmi azonos. Nietzsche tehát mind Kanttal, mind Hegellel szembefordul, mikor azt állítja, a konkrét-reális emberi létezésnek primátusa van a morális-ideális, „kívánatos” létezés eszméjével szemben. A történelem, és vele az emberiség nem egy ideális állapot felé kell, hogy haladjon, minthogy ilyen állapot nem létezik. Az abszolútum nietzschei tagadása azonban eltérő árnyalatot kap a Kant-, illetve a Hegel-kritika esetében, amennyiben előbbinél a metafizika, utóbbinál pedig inkább az absztrakt logika kritikáját jelenti. ${ }^{54}$ Kant az érzéki és érzékfeletti ellentétét a transzcendentalitásban próbálta feloldani, Hegel pedig a transzcendentalitást igyekezett

\footnotetext{
${ }^{51}$ Vö. G. W. F. Hegel: A szellem fenomenológiája. Ford. Szemere Samu. Akadémiai Kiadó, Bp., 1973. 9-46., illetve 403-415. o.

${ }^{52}$ U. ott 18 . o.

${ }^{53}$ Vö. u. ott 64-74., illetve 403-415. o.

${ }^{54}$ Vö. Viriato Soromenho-Marques:,Ontological Nihilism. How Hegel was read by Nietzsche.” In: Abstrakt und Konkret-Zwei Schlüsselkategorien des zeitgenössischen Denkens. Hg. Eduardo Chitas und Domenico Losurdo. Peter Lang, Frankfurt am Main/Wien, 2000, s. 141-148.
} 
megszüntetni a létezés és gondolkodás radikálisan időbeli elméletével, melyet azonban az abszolút cél tételezése és a negativitás teljes felszámolása végül mégis önmagába zárt.

Deleuze értelmezésében a differencia Nietzschénél a tagadás eredendően spekulatív fogalmát váltja fel, amennyiben a spekulativitás az oppozicionalitás, utóbbi pedig a metafizikai gondolkodás első értelme. ${ }^{55}$ Hegel gondolkodása Nietzsche szemében éppen dialektikus jellegénél fogva lesz a metafizika, mint olyan legáltalánosabb és legteljesebb elmélete, s mint ilyen, inspiráció és kihívás egyszerre. Hegel mind az egyes ember, mind a világegész totalizációját az ellentétek dialektikus egységben történő végső kibéküléseként képzeli el. A kulcsszó a totalizáció: egyén és világ már eleve rész-egész viszonyban állnak egymással, és mind az öntudat, mind az abszolút szellem a totalizációs folyamat végcéljaként definiált, az ellentéteket megszüntetve-megörző szintézisként. Hegelnél az emberi történelem a létezés partikuláris, illetve általános szintjén is a szellem önmagától való fokozatos elidegenedésének, tárgyiasulásának története, a cél tehát ezen folyamat visszafordítása. $\mathrm{Az}$ öntudat, illetőleg az abszolút szellem dialektikus egységformája tehát mindkét esetben a tárgyiasságot (elidegenedést) megszüntető szubjektum-objektum azonosság. Látni fogjuk: Nietzsche gondolkodása a kezdetektől fogva ellentétes irányú mozgást fejt ki. Azonban már most szükségesnek tartjuk jelezni, hogy Deleuze-t kizárólag a hegeli és a nietzschei differencia-fogalmak különbségének értelmezéséig tudjuk követni; Nietzsche filozófiájának a különbség hangsúlyozottan immanens fogalmára alapozott, számunkra talán még mindig túlzottan heideggeriánus értelmezésével azonban már nem értünk egyet. Minderről az értekezés második részének második fejezetében lesz alkalmunk bővebben szólni.

Térjünk vissza egy rövid időre a biográfiához. Wagnerék 1872-ben átteszik székhelyüket Bayreuth-ba, hogy személyesen felügyeljék a Festspielhaus építkezését, illetve az első Ünnepi Játékok egyéb előkészületeit, ez pedig kétségtelenül hasznára válik Nietzsche gondolkodói fejlődésének: Kant és Schopenhauer hatása, de mindenekelőtt a wagneri befolyás érezhetően gyengül. A tragédiakönyv kedvezőtlen szakmai fogadtatásának hatására Nietzsche bázeli hallgatói a tanév végére szinte elfogynak; ezt egyrészt roppantul fájlalja, de szíve mélyén jó értelemben vett „korszerütlensége” bizonyságának tartja. Ahogy Alexander Nehamas fogalmaz, Nietzschét az ezt követő négy évben is ugyanaz a három fő téma foglalkoztatja, mint eddig, csak más perspektívából; ez a három téma pedig a görög filozófia relevanciája a korabeli német kultúra szempontjából, valamint Schopenhauer, és végül, de

\footnotetext{
${ }^{55}$ Vö. Deleuze (1999) 23-26. o.
} 
nem utolsó sorban Wagner. ${ }^{56}$ Minél jobban elmerült a Szókratész előtti gondolkodók tanulmányozásában, annál több kérdés merül fel benne a létezés és a megismerés problémái kapcsán. A hagyatékból előkerült ifjúkori művek közül az egyik legfontosabb a torzóban maradt Filozófia a görögök tragikus korszakában. Ebben Nietzsche azt állítja, a filozófia csak az „egészséges” népekre nem ártalmas, mert a tudásvágy elszabadulása végül ugyanúgy barbársághoz vezet, mint a hiánya. A görög filozófia fénykora a Szókratész előtti időszak volt, mert akkoriban az emberek még nem a puszta megismerés, hanem az élet érdekében, tehát termékenyen tanultak. (Ahogyan A tragédia születésében írja, Szókratésszel jött el a teoretikus ember kora.)

Nietzsche a hét legjelentősebb preszókratikus gondolkodó portréját rajzolja meg, mindegyikük gondolkodásában három-három sarkalatos pontra koncentrálva. ${ }^{57}$ Thalész filozófiája az intuitív gondolkodás melletti legfőbb érv: Nietzsche szerint a „minden Egy” tétele, minthogy értelemszerüen nem alapulhat empirikus megfigyelésen, sokkal inkább misztikus-metafizikai sugallat. Voltaképpen Thalész ismerte fel az átváltozás és átváltoztatás jelentőségét, mely már megelőlegezi az igazság metaforikus jellegének gondolatát, de a létezés csak Anaximandrosznál vált etikai problémává, a sokféleség pedig morális fenoménné: a meghatározatlan ős-Egytől való emancipálódás meghatározott, tehát múlandó sokaságot eredményez: a keletkezés és a létezés tehát eredendően bünös. Nietzsche szemében Anaximandrosz „tragikus hős”, akin keresztül már Kantot és Schopenhauert hallja szólani. Az ő valódi hérosza azonban Hérakleitosz, aki elődjétől eltérően kizárólag a keletkezést [Werden] ismeri el állandónak: a mindenkori „világ” az ellentétek harcának pillanatnyi állását tükrözi; az örök igazságosságot éppen az garantálja, hogy ebben a harcban sosem volt, és sosem lesz végső győztes. A világ a tüz, a gyermek Zeusz önmagával való játéka, a folyamatos keletkezés tökéletes ártatlansága. „Mostantól örök szemlélői vagyunk annak, amit ő észrevett, a keletkezésben megnyilvánuló törvény és a szükségszerüségben rejlő játék tanának: ő húzta fel a legnagyobb színjáték függönyét”58 - ez Nietzsche „végső hálája” Hérakleitosz iránt. ${ }^{59} \mathrm{~S}$ hogy miért állítja Nietzsche, hogy a hübrisz gondolatának megértése a

\footnotetext{
${ }^{56}$ Vö. Nehamas (2002) p. 30.

${ }^{57}$ Ahogyan írja is: „,egy gondolkodó portréját három anekdotából meg lehet adni.” FGTK 55. o.

${ }^{58}$ FGTK 97. 0 .

${ }^{59}$ Utalás a Vidám tudomány 107. aforizmájának címére: „Végső hálánk a művészet iránt” („Időnként ki kell pihennünk magunkat, úgy, hogy kitekintünk és lepillantunk önmagunkra a müvész távlatából, nevetünk magunkon, vagy sírunk magunkon: a hőst éppen úgy kell felfedeznünk, mint a bolondot, aki megismerő szenvedélyünkben rejtőzik, időnként derülnünk kell ostobaságunkon, hogy bölcsességünkhöz hüek maradjunk...")
} 
Hérakleitosz-tanítványok végső próbatétele ${ }^{60}$ Magyarázatul szolgál az általa idézett görög közmondás: ,az elégedettség szüli a hübriszt (vétket) ${ }^{\text {"61 }}$ - minden keletkezés individuációt, az ős-Egytől való elszakadást jelent, tehát eredendően bünös, ahogyan azt már Anaximandrosznál láttuk. Hérakleitosz azonban rájött: a beteljesülés szüli az újabb vágyat, ezért van, hogy csak a folyamatos keletkezés ártatlan. Ezen a ponton nem tudunk egyetérteni Biczó Gáborral, aki így ír a nietzschei időfelfogásról:

Nietzsche két összefüggésben is szigorú logikai kapcsolatot tételez keletkezés és létezés között. Egyrészt ahogy ezt $A$ tragédia születésében már láthattuk - a keletkezés mindig individuáció, vagyis a primordiális homogenitással szemben elkövetett hübrisz, amennyiben minden keletkezés, lényegében a szó szoros értelmében vett genezis: létrejövetel. Minden keletkezés-esemény következménye individuális létezés, ugyanakkor minden létező elsődleges nembeli tulajdonsága időisége. Minden, ami „van” az időben létezik, és maga az idő a keletkezéssel keletkezik. Másrészt, a keletkezés struktúrájának ezen korai elemzése a létrejövetelt, a primordiális homogenitásból való kiszakadás folyamataként mutatja be, ahol maga a folyamat időben lejátszódó esemény. Az idő minden keletkező individuális létezőre azonos mértékben kirótt büntetés. A „van”, a „volt” és a „lesz” közé beékelt örök ellentmondása az időnek, vagyis csak az „van”, ami keletkezik, a létezés valami, ami önmagában oszthatatlan és csak önmagával azonosítható totalitás. ${ }^{62}$

Biczó végül arra a konzekvenciára jut, hogy a korai müvek Nietzschéje számára a keletkezés és létezés közti viszony tehát etikai és ontológiai értelemben is problematikus, és ezt az ellentmondást majd csak a második Korszerütlen oldja fel a „történelemfeletti” koncepciójával:

A történelemfeletti ember a világot a totális jelenlét örökkévalóságának egységeként szemléli, a pillanatok együtt-játékának látja. Ez a perspektíva megkíméli a folytonos keletkezés minden pillanatot átható drámájától, a keletkezés és megsemmisülés az időpillanatokban egymásra következő „szomorújátékától”. Nietzsche szerint tehát a történelemfeletti szemlélet meghatározó körülménye a jelenbeliség. ${ }^{63}$

\footnotetext{
${ }^{60}$ Ld. FGTK 90. o.

${ }^{61}$ Ld. FGTK 89. o.

${ }^{62}$ Biczó Gábor: „A »történeti lét« időstruktúrája Nietzsche korai bölcseletében.” In: Európa Nietzsche után. [Konferenciakötet, 2005] Online: http://filozofia.ektf.hu/koteteink/2005.html

${ }^{63} \mathrm{U}$. ott
} 
Azzal egyetértünk, hogy Nietzsche korai időfelfogásának két legfontosabb aspektusa az általa kiemelt hübrisz-problematika, illetve az idő-konstitúció kérdése (mely közvetlenül mutat az öntudat problémájára is). Vitába szállnánk azonban Biczóval a következő pontokon: 1. Nietzsche már $A$ tragédia születésében kijelenti: a létezés csakis esztétikai jelenségként igazolható. A keletkezés morális problémája a Filozófia a görögök tragikus korszakában címü írásban kerül kifejtésre, ahol is Nietzsche megállapítja: míg Anaximandrosznál a keletkezés még valóban etikai probléma, maga az ős-bün, addig Hérakleitosznál a keletkezés, és vele együtt a létezés is elveszíti bünös jellegét. Nietzsche ezzel kapcsolatban nagyon is egyértelmüen fogalmaz:

Van-e bün, jogtalanság, ellentmondás, szenvedés ezen a világon? Igen, kiáltja Hérakleitosz, de csak a korlátolt ember számára, aki a dolgokat külön-külön és nem együtt szemléli, ám nincs a contuitív istennek; számára minden ellentét harmóniába egyesül [...] Egyedül a művész és a gyermek játéka jön létre és múlik el, épül és pusztul örökké azonos ártatlansággal, mindenfajta morális járulék nélkül ezen a földön. És ahogyan a gyermek és a müvész játszik, úgy játszik az örökké eleven tüz is, épít és rombol ártatlanul - és ezt a játékot játssza az Aión önmagával. [...] Egy pillanatig elégedett, aztán ismét egyfajta vágy fogja el, ahogyan a müvészt is ez kényszeríti alkotásra. Nem gonoszság, hanem újraéledő játékösztön hoz létre más világokat. ${ }^{64}$

2. Figyelembe véve, hogy a preszókratikusokkal foglalkozó, azonban sajnálatos módon töredékben maradt írás nagyjából a második Korszerütlennel egy időben íródott, célszerübb lehet azt feltételezni, hogy a keletkezés eredendő bünösségének a tragédiakönyvben még markánsan jelenlévő gondolatát Nietzsche a Hérakleitosz-interpretációval kvázi revideálta. Ennek fényében azonban a történelemfeletti koncepciójában kifejtett idö-szemlélet a keletkezés-probléma etikai rehabilitációját követő, immár tisztán esztétikai temporalitáskonstrukció kiforrott, és, ami még ennél is jóval fontosabb: immáron valóban és vállaltan nietzschei kifejtése.

Folytassuk tehát a Nietzschével és a preszókratikus filozófusokkal. Parmenidész a létezők eredeti Egységéből indul ki, mikor a keletkezést és a gondolkodást a nem-létezőből a létezőbe történő átmenetként érti, méghozzá az ellentétek (ti. a pozitív és negatív minőségek) egymáshoz való vonzódása révén, melyet a vágy hajt, mely kielégülése után gyülöletté válik, ami pedig ismét nem-létezést eredményez. A nem-létező tehát nem valóságos, csupán

\footnotetext{
${ }^{64}$ FGTK 90-91. o.
} 
gondolati absztrakció. Zénón, továbbmenve, azt állítja, hogy ha minden érzéki puszta látszat, tehát nem-létező, akkor csak a fogalmak igazak és általános érvényüek. Nietzsche válasza: a fogalomról fogalomra haladó gondolkodás a sokféleség mozgása, tehát egyedül a változás örök! Anaxagorasz ott követte el módszertani hibát, mondja Nietzsche, hogy a kezdeti sokféleséget a létezők keletkezetlen pluralitásaként értette, melyben a változást nem a formák különbözősége, hanem az anyag azonossága indukálta - így tehát nem a különbség, hanem az azonosság örök, a végtelen pedig befejezett. Ugyanakkor az azonosból azonosba történő keletkezés mozgás, mely a nusz (értelem) lökése révén koncentrikus körökben terjed. Nietzsche úgy véli, egy ilyen, alapvetően lassuló mozgás csak annyiban tartható fenn, amennyiben céltalan, pontosabban célja önmagában van, akár a játéknak vagy a müvészetnek. „Úgy tünik, ez volt az a végső megoldás vagy kibúvó, ami a görögöknek mindig a nyelvük hegyén volt. [...] a keletkezés nem morális, hanem csak esztétikai jelenség." ${ }^{\circ 65}$

A preszókratikus gondolkodókról szóló munka már egyértelműen kijelöli a sajátosan nietzschei gondolkodás irányát. Bár a szakirodalomban létezik bizonyos konszenzus a tekintetben, hogy az 1876-os év fordulópontnak, tudniillik a baseli korszak lezárásának tekinthető Nietzschénél, véleményem szerint helyesebb már A tragédia születésének megjelenése utántól nyomon követni a változás folyamatát. Ne felejtsük el, hogy ebben az időszakban Nietzschének még nem titkolt célja volt egy valódi, „német” kultúra megteremtése, mely a filozófusok és a művészek együttmüködésével zajlott volna. ${ }^{66}$ Miután a dionüszoszi tragédiában meglelte a metafizikai vigasz eredetét, a létezést pedig esztétikai jelenségként mutatta fel, a preszókratikus filozófusok „anekdotáiból” két alapvető következtetést vont le; az első a metafizika, közelebbről az ontológia, a második pedig az episztemológia számára lesz meghatározó: 1. egyedül a keletkezés állandó, minden folyamatos alakulásban, létrejövésben van, az azonosság csak absztrakció. (A keletkezés állandóságának tézise kapcsán már most utalnunk kell Greg Whitlock remek tanulmányára, melyben Nietzsche egy kevésbé ismert, Slechta és Anders által „az idő atom-elméleteként” ${ }^{67}$ emlegetett töredékét elemzi. Nietzsche itt Roger Joseph Boscovich 18. századi fizikus,

\footnotetext{
${ }^{65}$ FGTK 143. o.

${ }^{66}$ KSA 7.423 „Gegen die ikonische Geschichtsschreibung und gegen die Naturwissenschaften sind ungeheure künstlerische Kräfte nöthig. Was soll der Philosoph? Inmitten der ameisenhaften Wimmelei das Problem des Daseins, überhaupt die ewigen Probleme zu betonen. Der Philosoph soll erkennen, was noth thut, und der Künstler soll es schaffen. Der Philosoph soll am stärksten das allgemeine Leid nachempfinden: wie die alten griechischen Philosophen jeder eine Noth ausdrückt: dort, in die Lücke hinein stellt er sein System. Er baut seine Welt in diese Lücke hinein Es sind alle Mittel zu sammeln, durch die es möglich ist den Menschen zur Ruhe zu retten: bei absterbenden Religionen! Den Unterschied in der Wirkung der Philosophie und der Wissenschaft klar zu machen: und ebenso den Unterschied in der Entstehung."

${ }^{67}$ KSA 7.575, ld. a függelékben. (A töredék a KGWharmadik kötetében 26[12] számmal szerepel.)
} 
asztronómus, matematikus, filozófus atom-elméletét alkalmazza saját, a későbbiekben „dinamikus világszemléletként” [dynamische Welt-Auslegung] aposztrofált elképzelésének alátámasztására. ${ }^{68} \mathrm{~A}$ problémával a fejezet végén található exkurzus foglalkozik bővebben.) 2 . Ebből következően az ,,igazság” maga is pillanatnyi, metaforikus. Ez utóbbi gondolatot kezdi kibontani A nem-morálisan felfogott igazságról és hazugságról c. írás, mely azonban sajnálatos módon szintén befejezetlen maradt,és valóban sajnálhatjuk, hogy így esett, ugyanis ezen a pár oldalon dönti le Nietzsche a nyugati gondolkodás első, és talán legnagyobb bálványát: tudniillik az igazságét - és innentől kezdve többé már nem is néz vissza. ${ }^{69}$ Ezzel nagyjából egy időben, 1872-73 telén két megmaradt hallgatója számára (egy jogász és egy germanista) tartja Retorikai előadásait, melyek jegyzetei szintén előkerültek a hagyatékból. A metaforikus, plurális igazság koncepcióját a két, említett szöveg párhuzamos olvasatán keresztül ismertetjük.

Nietzsche A nem-morálisan felfogott igazságról és hazugságról szóló szövegben azt állítja, hogy az ,igazság” fogalma már eleve egy csalás eredménye, melyet a többség követett el az uralom megszerzése céljából; itt használja először a „nyáj” [Herde] kifejezést a társadalom vonatkozásában. ${ }^{70} \mathrm{Az}$ igazságösztön az emberi létezés minden szintjén, az egyén és a társadalom esetében egyaránt az életösztönböl származik, és mint ilyen, nem válogat az eszközök közül. Egy szubjektív ingerről mindenki azt mond, amit akar, azonban ha elég sokan mondják ugyanazt, a szubjektívből objektív, az ingerből pedig igazság lesz. Az „,igazság”, melyet ily módon próbálunk már évezredek óta eltitkolni önmagunk elől (szintén egyéni és társadalmi méretekben egyaránt), ezzel szemben éppen az, hogy nincsen Igazság. Metaforák léteznek csupán, a dolgokra alkalmazott hasonlatok, melyek azonban sem a dolog

\footnotetext{
${ }^{68}$ Vö. Greg Whitlock: „Examining Nietzsche’s »time atom theory« fragment from 1873.” In: Nietzsche Studien 26. De Gruyter, 1997. pp. 350-360.

${ }^{69}$ Ezt alátámasztandó, Paul de Man Retorika-értelmezésére hivatkozunk, aki szerint azzal, hogy Nietzsche felismerte a nyelv retorikai struktúráját, megtalálta a kulcsot az általában vett metafizika-kritikához, hiszen, mint mondja, „bármely metafizikus konstrukció (a tudat fenomenalizmusa) nyelvi és retorikai szerkezetének ismeretében dekonstruálható”, illetve hogy Nietzsche ennek érdekében tudatosan használja az „ironikus allegória” retorikai formáját. (Vö. Paul de Man: „A trópusok retorikája.[Nietzsche.]” Ford. Vástyán Rita. In: Helikon, 1994/1-2. 36-47. o., különösen 40., ill. 46. o.) De Man tehát „nietzschei dekonstrukcióról” beszél, melynek alapja az a belátás, hogy a nyelv mint olyan figuratív jellegü, aminek egyenes következménye a metafizika alapfogalmainak kétségbe vonása. A dekonstrukció munkájának elvégzése után azonban mi magunk is szembesülünk az Igazság helyén támadt ürrel, mely ugyanakkor ,a referenciális igazság kényszere alóli felszabadulást" is jelent. Látni fogjuk, lényegében erről beszél Derrida is, mikor a reprezentáció lezárhatatlanságában rejlö kegyetlenségröl beszél. (Ld. Jacques Derrida: A kegyetlenség színháza. Paule Thévenin-nek. Ford. Farkas Anikó, Ivacs Anikó, et al. Online: http://www.literatura.hu/szinhaz/derrida.htm

${ }^{70} \mathrm{Vö}$. NMIH 4-5. o.. „Az intellektust rendesen csak önálcázásra használja; mivel azonban az ember szükségből és unalomból társadalmilag, másként: nyájban is létezni kíván [gesellschaftlich und heerdenweise existiren will], nem nélkülözheti a másokkal való békekötést [...] a dolgokat általánosan és kötelezően érvényes jelölésekkel (nevekkel) látják el; a törvényhozás a nyelvben az igazság első törvényeit is kijelöli: itt $\mathrm{s}$ ekkor jelenik meg elöször a kontraszt igazság és hazugság között.”
} 
magánvaló lényegét nem tükrözik, sem pedig puszta látszatnak, csökkentett létezésnek nem tekinthetők. A metaforaalkotás legalapvetőbb ösztönünk, érzékelésünk müködési elve: egy idegi ingert előbb képpé, majd hanggá alakítunk, így hozva létre a metaforákat, melyekről azonban az idők során elfelejtettük, hogy azok. Azonosítjuk a különbözőt, fogalmakat hozunk létre, azokból építjük fel tudatunk katakomba-szerü építményeit, melyben a kővé dermesztett metaforákat tároljuk. ${ }^{71}$ Mostanra már csak az álomban és a művészetben szabadulhatunk fel, mikor az intellektus helyére az ösztön lép. Kétféle ember van tehát: az értelemé, aki nem ismeri sem a kínt, sem a mámort, $\mathrm{s}$ ha mégis megtörténne bármelyik, az arcává forrott maszktól úgysem látszana; és az intuícióé, aki az életet mint egy derüs álmot éli meg, álmában örökké felhőtlenül boldog és könnyed, de ha szenved, nem ismer vigaszt.

Egyáltalán: »a helyes percepció« - ez az objektumnak a szubjektumban való adekvát kifejeződését jelentené számomra ellentmondásos és képtelen elmeszüleménynek tetszik, hiszen két olyan, mindenestül különböző szféra között, amilyen a szubjektum és az objektum, nincs kauzalitás, helyesség vagy kifejezödés, hanem mindössze esztétikai viszony lehet, értve ezen egy utalásszerú áttételt, egy dadogva-utánzó átfordítást egy egészen idegen nyelvre; amihez mindenesetre a külső találékonyság és szabadság közbülső szférájára és közvetítő tehetségre van szükség. ${ }^{72}$

\footnotetext{
${ }^{71}$ Nehamas szerint Nietzsche argumentációja minimum két ponton támadható, és végül épp ezek miatt nem közölte a müvet: 1. a felejtés kérdésében. Ha a hazugság képessége legalább annyira szükséges (ld. álom, müvészet), mint az igazmondásé, akkor hogyan történhetett meg valaha is, hogy megfeledkeztünk a hazugság hasznosságáról, és minden értéket az igazságnak tulajdonítottunk? 2. Ha szavaink valóban csak metaforák, és nem tükrözik az adott dolog természetét, honnan tudhatjuk, hogy nincs két egyforma dolog? Ez csak akkor lehetséges, ha az azonosság mégis korábbi, mint a különbség. Az első felvetés bizonyos fokig szinte zavarbaejtő, hiszen Nietzsche nagyon is érthetően kifejti, hogy paradox módon mind egy nagy, közös hazugságban élünk, amiről egyszerüen hasznosabbnak bizonyult elfeledkezni. Nehamas második ellenvetése arra vonatkozik, hogyha Nietzschének igaza van, és a dolgokról való tudásunk (szavaink, igazságaink) metaforikus jellegüek, tehát nem rendelkezünk az azonosság semmilyen fogalmával, akkor milyen alapon jelenthetjük ki, hogy nincs két egyforma dolog? Vö. Nehamas (2002) pp. 34-35. Nehamas kétségtelenül jól látja, Nietzsche itt lehetet volna alaposabb, de ne feledkezzünk meg két dologról: arról, hogy a tanulmány nem befejezett, valamint, hogy Nietzsche célja a Kanttal, illetve Schopenhauerrel való polémia. Ennek megfelelően a nietzschei plurálismetaforikus igazság elmélete a megismerés szigorúan a posteriori koncepciójának része, melyben az érzéki tapasztalat megelőzi az absztrakciót.

${ }_{72}$ NMIH 10. o. A müvészet szükségszerủ hazugságáról lásd többek között KSA 7.435 („Wir leben allerdings durch die Oberflächlichkeit unseres Intellekts in einer fortwährenden Illusion: d. h. wir brauchen, um zu leben, in jedem Augenblicke die Kunst”) és 7.488 („Wahrheitspathos in einer Lügenwelt. Lügenwelt wieder in den höchsten Spitzen der Philosophie. Zweck dieser höchsten Lügen Bändigung des unumschränkten Erkenntnißtriebes. Entstehung des Erkenntnißtriebes aus der Moral. [...] Woher das Wahrheitspathos in der Lügenwelt? Aus der Moral. Das Wahrheitspathos und die Logik. Die Kultur und die Wahrheit"); a metaforaalkotás ösztönös jellegéröl KSA 7.474 („Ich frage nicht nach dem Zwecke des Erkennens: es ist zufällig, d. h. nicht mit einer vernünftigen Zweckabsicht entstanden. Als eine Erweiterung oder als ein Hart- und Festwerden einer in gewissen Fällen nöthigen Denk- und Handelnsweise. Von Natur ist der Mensch nicht zum Erkennen da. Zwei zu verschiedenen Zwecken nöthige Eigenschaften-die Wahrhaftigkeit—und die Metapher-haben den Hang zur Wahrheit erzeugt. Also ein moralisches Phänomen, aesthetisch verallgemeinert, erzeugt den intellektuellen Trieb. Instinkt ist hier eben Gewohnheit, oft so zu schließen und daraus kata analogon eine Pflicht überhaupt immer so schließen zu müssen. [...] Die Natur hat den Menschen in lauter
} 
A Retorikai elöadások kissé eltérő megfogalmazásában mindez így hangzik: az első lépés „a tér átvitele az időre”, a második pedig ,az időről a kauzalitásra való áttétel”. ${ }^{73}$ Nietzsche itt leszögezi: a nyelv a hagyományos, sztoikus értelemben véve retorika, amennyiben nem ismeretet, csak vélekedést közvetít. A metafora, hasonlattal élve, pusztán a dolgok nemét jelöli meg, nyitva hagyva az újabb és újabb átértelmezések lehetőségét. Retorikai értelemben a jelentéshez való viszonyában minden szó trópus: a müvészi díszítés eszköze. „A szónok művészete az, hogy szónoklatában soha ne lehessen észrevenni a műviséget [...] karakterisztikus stílus [...] az ego kicserélődése [...] Játék ez az esztétikai és a morális határán. ${ }^{74}$ Mi pedig, egyszerre lévén jó szónok és hálás közönség, igazságoknak nevezzük a metaforákat, és alárendeljük nekik gondolkodásunkat; intellektusunk nem más, mint az individuum szolgája, melyet eszközként használ a dolgok feletti uralma, más szóval önfenntartása érdekében. Moralitásunk eredeténél egy hazugságot találunk, méghozzá a legnagyobbat: azt, amely az Igazság létezését hazudja. Abban a pillanatban azonban, mikor ráébredt, hogy ismereteink eredete az érzékelés, az Igazság pedig módszertani értelemben

Illusionen gebettet. - Das ist sein eigentliches Element. Formen sieht er, Reize empfindet er statt der Wahrheiten. Er träumt, er imaginirt sich Göttermenschen als Natur. Der Mensch ist zufällig ein erkennendes Wesen geworden, durch die unabsichtliche Paarung zweier Qualitäten. Irgendwann wird er aufhören und es. wird nichts geschehen sein. Sie waren es lange nicht und wenn sie selbst aufgehört haben zu existiren, wird sich nichts begeben haben. Sie sind ohne weitere Mission und ohne Zweck. Der Mensch ist ein höchst pathetisches Thier und nimmt alle seine Eigenschaften so wichtig als ob die Angeln der Welt sich in ihnen drehten. Das Ähnliche erinnert an das Ähnliche und vergleicht sich damit: das ist das Erkennen, das schnelle Subsumiren des Gleichartigen. Nur das Ähnliche percipirt das Ähnliche: ein physiologischer Prozeß. Dasselbe, was Gedächtniß ist, ist auch Perception des Neuen. Nicht Gedanke auf Gedanke - ”) és 7.489 („Das Nachahmen ist das Mittel aller Kultur, dadurch wird allmählich der Instinkt erzeugt. Alles Vergleichen [Urdenken] ist ein Nachahmen. So bilden sich Arten, daß die ersten nur ähnliche Exemplare stark nachahmen, d. h. dem größten und kräftigsten Exemplare es nachmachen. Die Anerziehung einer zweiten Natur durch Nachahmung. In der Zeugung ist das unbewußte Nachbilden am merkwürdigsten, dabei das Erziehen einer zweiten Natur. Unsre Sinne ahmen die Natur nach, indem sie immer mehr dieselbe abkonterfeien. Das Nachahmen setzt voraus ein Aufnehmen und dann ein fortgesetztes Übertragen des aufgenommenen Bildes in tausend Metaphern, alle wirkend. Das Analoge ,- ,) stb.

Különösen érdekesek számunkra azok a töredékek, melyek visszautalnak a korábban már említett disszertációtervezetre, még 1868-ból. Nietzsche ebben az „organikus” Kant utáni fogalmát és koncepcióját vizsgálja, és azt állítja, hogy a kanti ítélőerő egyszerűen tagadja a célszerütlenség tényleges cél-nélküliségét. Az egyetlen megoldás a teleológia és az optimizmus ellen, mondja már akkor is, a célszerütlenség igazolása. Ehhez lásd: KSA 7.435 („Der Kampf gegen die “Sinnlichkeit” durch die Tugend ist wesentlich ästhetischer Art. Wenn wir die großen Individuen als unsere Leitsterne gebrauchen, so verschleiern wir viel an ihnen, ja wir verhüllen alle die Umstände und Zufälle, die ihr Entstehen möglich machen, wir isoliren sie uns, um sie zu verehren") és 7.574 sk. („Ich habe nichts als Empfindung und Vorstellung. Also kann ich diese nicht aus den Vorstellungs-Inhalten entstanden denken. Alle jene Kosmogonien usw. sind erschlossen aus den Empfindungsdaten. Wir können uns nichts denken, das nicht Empfindung und Vorstellung wäre. Somit auch nicht rein Zeit, Raum Welt existirend, aber ohne das Empfindende und Vorstellende. Ich kann mir das Nichtsein nicht vorstellen. Das Seiende ist Empfindung und Vorstellung. Das Nichtseiende wäre etwas, was nicht Empfindung und Vorstellung wäre. Das Vorstellende kann sich nicht »nicht vorstellen«, wegvorstellen. Das Vorstellende kann sich nicht als geworden denken, noch als vergehend. Unmöglich auch die Entwicklung der Materie, bis zum Vorstellenden. Denn es giebt gar nicht diesen Gegensatz von Materie und Vorstellung. Die Materie selbst ist nur als Empfindung gegeben. Jeder Schluß hinter sie ist unerlaubt. Die Empfindung und die Vorstellung ist die Ursache, daß wir an Gründe Stöße Körper glauben. Wir können sie auf Bewegung und Zahlen zurückführen”).

${ }^{73}$ Vö. R 22-23. o.

${ }^{74}$ R 32-33. o. 
absztrakció, morális értelemben pedig hazugság, szöget üt a fejében a gondolat: nem létezik a magánvaló, sem a megismerésben, sem a létezésben; csak a változás van, a keletkezés és elmúlás egymásba alakulásának folytonossága: ez maga az élet. 1872-73 telén a következő mondatot jegyzi le: ,aKeletkezés és a Lét - ez eredményezi az egész különbséget.”75

Mindezek után nem sok kétségünk lehet afelöl, hogy Nietzsche voltaképpeni célja már ekkor is a teljes metafizikai hagyomány lerombolása - hacsak nem feltételezzük, hogy fel sem merült benne, milyen következményekkel fog járni, ha kijelenti, hogy az Igazság nem létezik. Persze nyilván az sem véletlen, hogy - bár a retorikai előadások elhangzottak, és Nietzsche nem sejthette, hogy csak két hallgatója lesz - az igazán botrányos, és cseppet sem félreérthető gondolatokat tartalmazó, egységes szövegnek szánt, címmel ellátott írás végül csak a hagyatékból került elö. De Nietzsche ekkor még Wagnerék udvartartásához tartozott, és örömmel volt a Mester szószólója, ha az így látta szükségesnek; ez történt az első Korszerütlen elmélkedés esetében is. A Korszerütlenek értelmezése kapcsán nem érthetünk teljesen egyet Rüdiger Safranskival, aki úgy véli, míg az első és a harmadik Elmélkedés Nietzschének a materializmussal, a második és a negyedik pedig a historizmussal szembeni polémiáját tükrözik, lévén e két jelenség az ifjú Nietzsche modernitás-kritikájának központi fogalma. Ehhez azonban hozzátartozik, hogy Nietzsche szándéka szerint a „Mi, filológusok” c. írás lett volna az ötödik Korszerütlen tanulmány, melyet azonban végül nem fejezett be. Ebben az esetben a Safranski-féle felosztásban inkább ez utóbbi lehetne a második historizmus-kritika, ugyanis a „Mi, filológusok” mondandóját tekintve sokkal jobban illeszkedik A történelem hasznáról és káráról szóló második Elmélkedéséhez, mint az 1876os Richard Wagner Bayreuthban. Utóbbi - bár a wagneri zenedrámában a mítosz újjászületésének lehetőségét, a természettel való közvetlenség rekonstrukciójának lehetőségét ünnepli, szemben a historizmus gyökértelen szemléletmódjával - jelentősége a Korszerütlensorozat zárásaként, és magában az életmüben is, ennél sokkal mélyebb és személyesebb. ${ }^{76}$

Ennyit elöljáróban, most pedig térjünk vissza az első Korszerütlenhez, melyet Nietzsche 1873-ban, Wagner kifejezett óhajára ír, a darwinista-materialista David Strauss, a hitvalló és író ellen. A mü első szintje a populizmus-kritika: a német kultúra a háborús győzelem dacára válságban van, e legtöbben azonban még sincsenek tisztában a helyzettel,

\footnotetext{
${ }^{75}$ KSA 7.546 „Naturwissenschaftlicher Rückblick. Theorie der Aggregatzustände.Theorie der Materie. Also Vermischung physikalischer und metaphysischer Probleme. Das Werden und das Sein-es ergiebt sich die volle Differenz." (kiemelés tölem, L. E.)

${ }^{76}$ A teljes Korszerütlen-sorozat kitüntetettségéröl az életmüvön belül lásd Daniel Breazeale: „Nietzsche: The Untimely Meditations.” In: Introductions to Nietzsche. Ed. Robert B. Pippin. Cambridge UP, Cambridge, 2002. pp. 67-90.
} 
mert elrejti előle a „Bildungsphilister”; a nyárspolgár, aki világfinak, kultúrlénynek képzeli magát. Sajnálatos módon az intézmények is ezt az embertípust nevelik ki; ${ }^{77}$ a középszer pedig elnyomja az igazi stílust, ami minden valódi kultúra első ismérve. Senki nem hisz többé heroldokban, csak epigonokban: a klasszikus már nem követendő példa, pusztán történelmi múlt. Ami a továbbiakban következik, az David Strauss kíméletlen és módszeres ellehetetlenítése, ${ }^{78}$ mely azonban gondolatmenetünk szempontjából nem releváns, ezért tovább is lépünk a második Korszerütlen elmélkedésre. Ebben a történeti gondolkodás és a modernitásban uralkodó epigon-létmód ellen intéz kíméletlen támadást Nietzsche, mondván: az egy bizonyos határon túl már kifejezetten életellenes; a történelemre csak annyiban van szükség, amennyiben az életet segíti.(Erre utal a teljes cím is: A történelem hasznáról és káráról az élet számára. ${ }^{79}$ ) A felejtés képessége elengedhetetlen, hiszen az emlékezésben csak korlátainkat látjuk, jelenünket és a jövőben rejlö lehetőségeket viszont nem. Egy ember, nép, vagy akár kultúra „plasztikus erejének” nevezi a magából és magától történő növekvés erejét, ${ }^{80}$ melyben a történeti és történetietlen, az emlékező és a felejtő tendencia hasonlóképp van együtt, mint az apollóni és a dionüszoszi elem a tragédiában: a történetietlen, felejtésre képes elemnek túlsúlyban kell lennie, mert ő jelenti a cselekvő potenciált. Aki pedig a nietzschei értelemben „,cselekvő”, az mindig történetietlen, lelkiismeretlen, igazságtalan, „S

\footnotetext{
${ }^{77}$ Vö. Friedrich Nietzsche: Müvelödési intézményeink jövőjéröl: hat nyilvános elöadás. Ford. Óvári Csaba. Attraktor, Máriabesnyő, 2011. 8, illetve 11-25. o. Nietzsche szerint az eredendően jó szellemben müködő német intézményeket a modernizáló szándék tette tönkre. A hanyatlás jelei: a műveltség maximális „szélesítése”, ezzel együtt pedig „kevesbítése és gyengítése”. Éppen ezek ellentétére van tehát szükség, ti. a műveltség körének szúkítésére-koncentrálására, melynek következménye annak erösödése és „önmagával beérö volta”.

${ }^{78}$ A teljesség kedvéért: Nietzsche szemében David Strauss a tipikus „Bildungsphilister”, A régi és új hit [,Der alte und neue Glaube"] címü müvét hitvallásnak, egyszersmind irodalmi alkotásnak szánta, de mindkettőnek igen gyenge, mégpedig a következő okokból: 1. Strauss idealizálja a korabeli német mindennapokat, szerinte az maga a földi paradicsom, mely tobzódik diadalban, tudományos forradalmakban, és magas szintü műveltségben. Ez nyilvánvaló hazugság: a német kultúra nem diadalmaskodott a francián, mert utóbbi kétségtelenül van, elöbbi viszont jelenleg nem létezik, továbbra is csak mímeli a francia szellemet. A tudósok csak gyüjtögetnek és elemeznek, az újdonságok elől riadtan zárkóznak el, a müveltség pedig egyre szélesebb körü és ezzel párhuzamosan egyre silányabb színvonalú. Strauss realista optimizmusa teljesen indokolatlan, és nyilvánvalóan saját, alacsony szintủ és elhibázott irányú műveltségében gyökerezik: Kant és Schopenhauer helyett Hegel és Schleiermacher nyomdokain halad. 2. Ennek ellenére, vagy éppen ezért a gyávák és hazugok módszerét alkalmazza: maga sem biztos a dolgában, ezért hangosan kiabál, majd a zürzavart kihasználva eltünik. Nagyot akar mondani, de nem várja meg, mi lesz a következménye. Bár elhatárolja magát a kereszténységtöl, és Darwint élteti, mégsem meri vállalni annak erkölcsi következményeit, ehhez ő túlontúl gyáva. Ehelyett, teljesen irracionális módon Darwin tanaiból egyfajta „humanizmust” vezet le, amelyben mindannyian együvé tartozunk az emberiség hatalmas testvériségében. 3. Strauss hitvallóként és íróként is filiszter: tézisei ostobák, de legalább bátortalanok és következetlenek, stílusa középszerű zsurnalizmus. (Vö. DS 7-92. o.)

79 Egyetértőleg hivatkozunk a Heidegger-tanítvány, Joan Stambaugh értelmezésére, mely az időtudat problémáját tartja a második Korszerütlen központi kérdésének. A múltról való tudásunk az, aminek köszönhetően van jelenünk, mely nem más, mint múlt-pillanatok egymásba folyása, mely ugyanakkor már elörevetíti a jövő lehetőségét. Maga a jelen így sosem jelenlévő, hanem mindig csak keletkezö. (Ld. Joan Stambaugh: The Problem of Time in Nietzsche. Trans. John F. Humphrey. Bucknell UP, Lewisburg, 1987, pp. 40-60.) Nietzschénél tehát múlt, jelen, jövő nem potenciáljai, hanem egyszerre jelen lévő, konstitutív elemei az időnek, nála keletkezés és pusztulás elválaszthatatlanok.

${ }^{80}$ Ennek megnyilvánulása lenne az „önmagával beérő” műveltség is, lásd fentebb, lábjegyzetben.
} 
csupán egyetlen jogot ismer, annak a jogát, aminek most kell keletkeznie"81 - ő a „történelemfeletti” ember. Igen, ez már Nietzsche hangja! Majdnem pontosan ugyanazt a kérdést teszi fel, amit majd a Vidám tudomány legfontosabb pontján fogunk tőle hallani: „,akarod-e újraélni, ami elmúlt?” A történeti ember felelete egyértelmü „nem”, hiszen ő eleve nem élni, pusztán emlékezni akar, mondja Nietzsche, míg a történelemfeletti ember azért mond nemet, mert számára minden pillanat befejezett. A történelemhez való háromféle viszonyulás (monumentális, antikvárius, kritikai) közül a kritikai hozzáállás lehet a leggyümölcsözőbb, mondja Nietzsche, de ugyanakkor ez a legveszélyesebb is: ítéletet mondani a múlt felett, melyből mi magunk is származunk, méghozzá a „teremtő felettelebegés” perspektívájából. „Kísérlet ez, mintegy a posteriori adni magunknak olyan múltat, amelyből származni szeretnénk" - önmagunk teremtő felülmúlása tehát a cél már itt is, abban a tudatban, hogy „,minden győzelmes második természet elsővé válik”" ${ }^{82}$ Nietzsche itt ismét veszélyesen közel merészkedik a hegeli dialektikához - legalábbis remek támadási felületet biztosít az ilyen irányú támadások számára. Ezekre nehezen találhatnánk összeszedettebb választ annál, mint amit Schreiner Dénes ad második Korszerütlen körültekintő értelmezésekor. ${ }^{83}$ Emlékeztet rá, hogy Nietzsche számára a világ esztétikai jelenség, melyben nincsen kauzalitás vagy célszerüség, ez pedig pontosan ellentétes a hegeli abszolút szellem elméletével, melynek önmagához való visszatérése a történelem végcélja. Hegelnél a történeti vizsgálódás objektív tárgyakra irányul, Nietzsche kritikus történelem-szemlélete ezzel szemben a múlt és jelen közti feszültségből származó tapasztalatokra támaszkodik. Mikor a történelemfeletti ember minden pillanat befejezettségéről beszél, nem az abszolutizálódás dialektikus folyamatának végeredményére gondol, hanem a horizont pillanatnyi, azaz az adott perspektíva által meghatározott zártságára, amely a történelemfeletti történeti mozzanata - a perspektivikus jelleg viszont a történetietlen. ${ }^{84}$

Az 1874-es keltezésű harmadik szöveg Schopenhauer mint nevelö példáján keresztül mutatja be a materializmus és a dionüszoszi világnézet közti ellentétet. Nietzsche itt magyarázza meg, mit is ért „korszerütlenségen”: „,egyszerünek és becsületesnek lenni, mind a

\footnotetext{
${ }^{81}$ THK 102. o.

82 THK 117. o.

${ }^{83}$ Schreiner Dénes: „A művészet szerepe Nietzsche kultúrkritikájában.” In: Ész, természet, történelem. Filozófiai tanulmányok. Szerk. Czeglédi András et al. Bp., Áron Kiadó, 2004, 77-108. o.

${ }^{84}$ Hasonló következtetésre jut Lacoue-Labarthe, aki szerint Nietzschénél a kultúra organizmushoz hasonlít, mely elevenségében saját magát hozza létre, horizontja folyamatosan keletkezik és alakul. Azonban éppen ennyire fontos, hogy horizontunk e végtelen nyíltságából vissza tudjon záródni a határoltba, ugyanis ez biztosítja az egyediség értelmében vett egy-ségét. Ez egyfajta „onto-mimetológia” Nietzschénél, aki tudniillik ,az életet fogta fel a müvészet mintájára, és nem fordítva”. (Vö. Philippe Lacoue-Labarthe: „Történelem és mimézis.” Ford. Betegh Gábor. In: Athenaeum, 1992 I/3. A francia Nietzsche-recepció. 242-264. o.)
} 
gondolkodásban, mind az életben" ${ }^{„ 85}$ - ezek az értékek, valljuk be, manapság is „korszerütlenek”. Schopenhauerben azonban Nietzsche mindezeket együtt látja, és úgy véli, épp ezért lehet az eljövendő nemzedékek legjobb nevelöje. Persze veszélyes is lehet, ha őt követjük, ekkor ugyanis elkerülhetetlenül szkeptikusak leszünk az igazsággal kapcsolatban; de vállalnunk kell ezt a kockázatot, hiszen csak ekkor élünk igazán. Különösen így van ez egy olyan korban, mikor a mítosz eltünt a világból, az egyes embert a többi emberhez és a természethez füző kötelékek eloldódtak - jellegzetesen wagneri gondolat -, a helyére lépő vallás, erkölcs és tudomány pedig teljes mértékben szekularizálódott. Választhatunk: jöhet a rousseau-i ember és a szociális forradalom; a goethei nyugodt szemlélődés; vagy csatlakozhatunk Schopenhauerhez, és vállalhatjuk az igazsággal való szembenézés fájdalmát: aki ugyanis átérzi a létezés rettenetét, arra nem vár más, mint szenvedés. Schopenhauer mutatott rá, hogy a számunkra egyedül elérhető beteljesülés, hogy ezt képesek vagyunk tudatosítani magunkban - ez a metafizikai vigasz igazi jelentése. Ennél azonban jóval fontosabb az, amire Nietzsche utal, mikor a schopenhaueri hősiességet magyarázza: „minden létezés, amely tagadható, meg is érdemli a tagadást; igazlelkűnek lenni pedig annyit jelent: hinni az olyan létezésben, amely egyáltalán nem is lenne tagadható, mivel igaz és mentes minden hazugságtól." ${ }^{86}$ Nietzsche ugyanis itt jóval tovább megy, mint Schopenhauer valaha is tette - ő megállt volna a mondat első felénél; ez a schopenhaueri pesszimizmus és akarattagadás értelme. Nietzsche Schopenhauert dicsőíti, de közben saját meggyőződésének ad hangot - hiszen „az intellektus, mint az individuum önfenntartásának eszköze, leginkább az önálcázásban mutatja meg, mire képes". ${ }^{87}$ A heroikus ember képes a teljes önfeledtségre, de önmaga folyamatos meghaladására is - így lesz majd később „emberfeletti”... Korábban utaltunk a sorozat tervezett, ám soha meg nem jelent ötödik részére, és abbéli véleményünknek adtunk hangot, hogy tematikájában talán szorosabban kapcsolódik az előző három részhez, mint a Richard Wagner Bayreuthban, így vegyük ezt előre. A filológiával kapcsolatban nem sokat változott Nietzsche véleménye az 1869-es székfoglaló óta; meggyőződése, hogy csak akkor van létjogosultsága, ha képes alkalmazkodni megváltozott helyzetéhez. A Mi, filológusokban, ebben a nagyon is szangvinikus írásban Nietzsche azt várja a filológiától, hogy szünjön meg annak lenni, ami mindezidáig volt: tudniillik az ókor iránti nosztalgiának, mely a jelen iránti tehetetlenségünkből táplálkozik. Az új filológiának a

\footnotetext{
${ }^{85}$ Vö. SN 189. o.

${ }^{86}$ SN 214. o.

${ }^{87}$ NMIH 4. o.
} 
szó legnemesebb értelmében vett nevelésnek kell lennie, az alkotás müvészetének, de ezzel együtt kíméletlen kritikának. ${ }^{88}$ Az új filológus: az új Nietzsche? ${ }^{89}$

Elérkeztünk hát ahhoz az íráshoz, mely végül ténylegesen lezárta a Korszerütleneket, és Nietzsche életének egyik kiemelkedő jelentőségü szakaszát. A hátrahagyott jegyzetek tanúsága szerint Nietzschében már jó ideje kettős érzelmek dúltak a Mesterrel kapcsolatban: egyrészt, a Wagner család költözése óta módja nyílt egy sokkal távolságtartóbb, kritikusabb pozícióból pillantani eszmére és emberre egyaránt; ennek pedig, bár sokáig maga elől is titkolni próbálta, mindkét tekintetben kiábrándulás lett az eredménye. A másik oldalon viszont ott volt Nietzsche feltétlen lojalitása, mely barátként és tanítványként nem kockáztatott semmit, amivel bármilyen módon is árthatott volna a bayreuthi vállalkozás sikerének. A Richard Wagner Bayreuthban Nietzsche életének legfájdalmasabb, de ugyanakkor a leginkább sorsdöntő eseményéről: a Wagnerrel és a wagnerizmussal való végső szakításról szól. Megtudjuk belőle, hogy Wagner varázsereje személyiségének kettős természetében rejlik: egyszerre hataloméhes zsarnok és isteni ártatlansággal alkotó művész; ${ }^{90}$ ennek révén válik alkalmassá egy ilyen hatalmas vállalkozás véghezvitelére. De Bayreuth, eredeti értelmében, nem egy fényes külsőségek között zajló udvari ünnepség, hanem csatakiáltás, mely csak az igazán bátrakat, a harcosokat és újítókat szólítja; a legteljesebb értelemben „korszerütlen”. Wagner a zene erejével visszavezeti az embert a természethez és embertársaihoz, de nem azokat, akik szolgamód követik: ő azokhoz szól, akik elég bátrak a szabaddá váláshoz. Nietzschét azonban, aki már a főpróbák idején megérkezett Bayreuthba, még a vártnál is nagyobb csalódás fogadta: pompa, csillogás, talpnyalás és középszerü, ostoba szalon-zsivaj - pár nap múlva elkeseredetten menekült a klingenbrunni erdőkbe, ahol papírra

\footnotetext{
${ }^{88}$ Vö. Friedrich Nietzsche: „Gondolatok és vázlatok a Mi, filológusok című korszerütlen elmélkedéshez.” In: Nietzsche (1988) 151-164, illetve 223-246. o.

${ }^{89} 1874$ áprilisában írja Gersdorffnak: „Kétely kétely hátán. A cél túl messze van, és mire az ember szinte eléri, addigra az erejét legtöbbször felemészti a hosszas kutatás és a küzdelmek: szabad lesz, és olyan bágyadt, mint egy alkonyi tiszavirág. Ettől nagyon félek. Balszerencse ennyire tudatában lenni saját harcunknak, és ilyen korán!” / BVN-1874,356. („Brief an Carl von Gersdorff.”) „Zweifel über Zweifel. Das Ziel ist zu weit, und hat man's leidlich erreicht, so hat man meistens auch seine Kräfte im langen Suchen und Kämpfen verzehrt: man kommt zur Freiheit und ist matt wie eine Eintagsfliege am Abend."

${ }^{90} \mathrm{RWB}$ 303. o. „Ha Wagner fejlődését ugyanígy valamilyen belső akadállyal akarjuk összefüggésbe hozni, akkor azt kell feltételeznünk, hogy színészi őstehetség rejtezik benne, amely színészhajlam a megszokott, triviális módon nem tudott kielégülni, amely valamennyi művészetnek egyetlen nagy színészi produkcióba való bekapcsolásával kereste a megoldást. De ugyanilyen jogon mondhatnánk azt is, hogy egy hatalmas zenésztermészet - kétségbeesésében, hogy félművelt zenészekhez és nem zenészekhez kell szólnia - erőszakosan feltépte a többi müvészethez vezető átjáró ajtaját, hogy végre százszoros világossággal nyilatkozzék meg, és megértést, a lehető legszélesebb körü megértést verekedjen ki magának. Bárhogyan képzeljük is el az öseredeti drámaköltő fejlődését, érett és kifejlett alkotóként túl van bármiféle gátoltságon és elégtelenségen: valóban szabad művész ö, aki nem tehet mást, mint hogy valamennyi művészetben egyszerre gondolkodjék; közvetítő és kibékítő, egymástól látszólag teljesen különválasztott szférák között, visszaállítója a müvészi képességek egykor volt egységének és egyetemességének, amelyet nem lehet kitalálni és kikövetkeztetni, csak tettel bizonyítani."
} 
vetette az Emberi - túlságosan is emberi első jegyzeteit. Mégsem tudott nyugodni, és visszatért a bemutatóra, ahol be kellett látnia: számára lezárult a Wagner-korszak. A Mester által elfoglalt hely végérvényesen megüresedik, Nietzsche pedig Paul Rée-vel, akivel ekkor már hónapok óta levelezik annak Psychologische Beobachtungen címü müve kapcsán, a „bölcsek telepét” tervezi megalapítani. A filozófus 1876 októberétől egyéves betegszabadságot kér, mert fizikai és lelki-szellemi értelemben is: rosszullétei, melyek napokig tartó fejfájás- és hányás-rohamokkal járnak, lehetetlenné tették számára oktatói teendőinek ellátását. Rée Nietzschével utazik Sorrentóba; ekkor, 1876. november 1-jén történik meg Wagner és a filozófus utolsó beszélgetése. Ezután kezdetét veszi a „kijózanító kúra”, Nietzsche pedig „nem akar többet, mint hogy nap mint nap elveszítsen valamely megnyugtató gondolatot". 91

\section{Exkurzus: Az örök visszatérés „fizikája”. Nietzsche és Boscovich}

Mint fentebb utaltunk rá, egyetértünk Greg Whitlockkal a tekintetben, hogy Roger Boscovich atom-elméletének hatása a nietzschei gondolkodás, különösen az örök visszatérés koncepciója tekintetében hatalmas jelentőségü. Nietzsche, levelezése és jegyzetei tanúsága szerint, még 1873-ban megismerkedett a jezsuita természettudós-filozófus atomelméletével. ${ }^{92}$ Boscovich teóriája két axiómára épül: az első a kontinuitás elve: semmi sem

\footnotetext{
${ }^{91}$ BVN-1876,552. („Brief an Louise Ott.”) „An einen Menschen, der nichts mehr wünscht als täglich irgend einen beruhigenden Glauben zu verlieren, der in dieser täglich grösseren Befreiung des Geistes sein Glück sucht und findet. Vielleicht dass ich sogar noch mehr Freigeist sein will als ich es sein kann!”

${ }^{92}$ Többször említette Boscovich-ot Peter Gastnak, polgári nevén Heinrich Köselitznek (Nietzsche nevezte így a zeneszerzőt Mozart Don Giovannijának „,kővendége” után; a Petrus latin eredetủ név, jelentése 'kő', míg Gast németül 'vendég'). Ld. pl. BVN-1882,213. („Brief an Heinrich Köselitz.”) „Wenn irgend Etwas gut widerlegt ist so ist es das Vorurtheil vom »Stoffe«: und zwar nicht durch einen Idealisten sondern durch einen Mathematiker - durch Boscovich. Er und Copernikus sind die beiden grössten Gegner des Augenscheins: Seit ihm giebt es keinen Stoff mehr, es sei denn als populäre Erleichterung. Er hat die atomistische Theorie zu Ende gedacht. Schwere ist ganz gewiß keine »Eigenschaft der Materie«, einfach weil es keine Materie giebt. Schwerkraft ist, ebenso wie die vis inertiae, gewiß eine Erscheinungsform der Kraft (einfach weil es nichts anderes giebt als Kraft!): nur ist das logische Verhältniß dieser Erscheinungsform zu anderen, zb. zur Wärme, noch ganz undurchsichtig. - Gesetzt aber, man glaubt mit M(ayer) noch an die Materie und an erfüllte Atome, so darf man dann nicht dekretiren: »es giebt nur Eine Kraft«. Die kinetische Theorie muß den Atomen mindestens außer der Bewegungsenergie noch die beiden Kräfte der Cohaesion und der Schwere zuerkennen. Dies thun auch alle materialistischen Physiker und Chemiker! und die besten Anhänger M(ayer)s selber. Niemand hat die Schwerkraft aufgegeben! - Zuletzt hat auch M(ayer) noch eine zweite Kraft im Hintergrunde, das primum mobile, den lieben Gott, - neben der Bewegung selber. Er hat ihn auch ganz nöthig!" Illetve lásd még BVN1883,460. („Brief an Heinrich Köselitz.) „Ein Stück aus einer solchen ist zB. von Gomperz (in den Berichten der Wiener Academie) entziffert worden: es handelt von »der Freiheit des Willens « und ergiebt als (wahrscheinliches) Resultat, daß Epicur ein heftiger Gegner des Fatalismus war, aber dabei - Determinist: - was Ihnen Vergnügen machen wird! (Damals trieb ich die Atomenlehre bis hin zum Quartanten des Jesuiten Boscovich, der zuerst mathematisch demonstrirt hat, daß die Annahme erfüllter Atompunkte eine für die
} 
történik ugrásszerüen, hanem csak átmeneteken keresztül; a második pedig az áthatolhatatlanság elve: két materiális pont nem foglalhatja el egyszerre ugyanazt a helyet a térben. Az ún. „materiális pontoknak” ugyanis nincs kiterjedése, nincsenek részeik, éppen ezért nem is tudnák megakadályozni, hogy egy másik materiális pont elfoglalja az adott helyet a térben. Másodszor, fontos a „materiális” és a térbeli pontok fogalmának megkülönböztetése: míg előbbiek száma véges, utóbbiak konstituálják a háromdimenziós végtelent; így aztán lehetetlen, hogy két anyagi pont, egy irányító aktivitása nélkül egyáltalán összeütközzön, nemhogy egy helyen legyen egy időben. A második axióma következménye: két anyagi pont között nem létezhet kapcsolat, nem képezhetnek folyamatosságot, sőt, még matematikai kapcsolatban sem lehetnek egymással. Minden két pont között kölcsönhatás áll fenn, melynek ereje a köztük lévő távolság függvénye. Egy egyedi anyagi pont tehát önmagában nem érzékelhető; csak más anyagi pontokkal való kapcsolatában válik azzá. A Boscovich-féle materiális pont nem azonos a leibnizi kiterjedés nélküli monásszal, hiszen a dinamikus elmélet eliminálja azt a szubsztanciális jelleget, amivel utóbbi még rendelkezett. Mivel azonban az anyagi pontnak nincs kiterjedése, így tömege sincs, tehát a legkisebb erő, amiről szó lehet, az a kettejük egymáshoz való közeledésének vagy egymástól való távolodásának ereje; a két pont közti vonzás vagy taszítás mértéke pedig véges kell, hogy legyen. A végtelenség ekkor a következőképp értendő: adott az egész számok skálája, melyben tehát nincsen végtelen szám, de a számsor maga végtelen, nincsen utolsó tagja. Ezért e tér bármilyen kis területén elfér végtelenül sok anyagi pont, és akármeddig növeljük is ezek számát, az mindig véges marad - „az univerzum nem az anyagban szétszóródott vákuum, hanem az anyag van a vákuumban szétszóródva, és abban úszik”. 93 Az „erő törvénye” a következő: az egészen kis távolságok esetében az erők taszító hatást fejtenek ki, és taszítóerejük a távolságok csökkenésével párhuzamosan nő, oly módon, hogy képesek lesznek bármilyen ellentétes irányú erő semlegesítésére, mellyel egy adott pont egy másikhoz közeledhet, még azelőtt, hogy a köztük lévő távolság eltünne. Ha viszont a távolság növekszik, az erők vonzóerőkké változnak; melyek először nőnek, azután eltűnnek és taszító erőkké válnak; és így tovább, felváltva, távolságok végtelen hosszú során keresztül. ${ }^{94}$

\footnotetext{
strengste Wissenschaft der Mechanik unbrauchbare Hypothese sei: ein Satz, der jetzt unter mathematisch geschulten Naturforschern als kanonisch gilt. Für die Praxis der Forschung ist er gleichgültig.)" (kiemelések tőlem, L. E.)

${ }^{93}$ Roger Joseph Boscovich: A Theory of Natural Philosophy. Trans. J. M. Child. Open Court Publishing Company, Chicago-London, 1922. Art. 7.

${ }^{94}$ Ld. Boscovich (1922) Art. 7., 32., 48., 383., 391.
} 
Nietzschét Boscovich elméletéből elsősorban nem az atomok karakterisztikája, hanem inkább az erö törvénye foglalkoztatja. Az „,atomista szükségletet” egyébiránt az általánosabb „metafizikai szükséglet” egyik csökevényének, és a „lélekatomisztika”, vagyis a lélek oszthatatlanságába és halhatatlanságába vetet hit eredőjének tartja, tehát azokkal együtt megsemmisítésre ítéli. ${ }^{95}$ Azzal, hogy cáfolta a végtelen feloszthatóság lehetőségét, Nietzsche szerint Boscovich végképp lehetetlenné tette a materialista atomisztikában való hitet. Mindezen az sem változtat, hogy éppen a materiális pontok oszthatatlanságából és áthatolhatatlanságából következően a végtelen kombinálhatóság lehetőségét fenntartotta. Boscovich dinamikus teóriája a materialista atomizmus alternatívája: a nem-anyagi ,anyag” elmélete. A materialista atomizmus ugyanis Boscovich szerint az atomokat, mint a létezés legkisebb egységeit, oszthatatlan, átjárhatatlan molekulákká, hordozókká degradálja, ily módon pedig általában véve teszi lehetetlenné a hatás mint olyan tapasztalatát, hiszen ez esetben csak két atom összeütközéséröl, illetve az annak következtében kialakuló pillanatnyi gyorsulásról beszélhetnénk. Ez azonban Boscovich számára nem kielégítő magyarázat, mivel ellentmond a kontinuitás törvényének. Az ő „materiális pontjai” tehetetlen anyagi pontok, melyeket taszító erők vesznek körül; így a sebességváltozás nem két atom pillanatnyi összeütközésének következménye, hanem a kis távolságokon belül müködő taszítóerő folyamatos munkájából adódik. A távolság csökkenésével párhuzamosan a taszítóerő növekszik, és a végtelenül kis távolság esetén a taszítóerő mértéke megközelíti a végtelent.

Nietzsche a Schlechta és Anders által felfedezett, ${ }^{96}$,Zeitatomenlehre” néven ismertté vált töredékben, ,,az idő atom-elméletében”97 a következőképp adaptálta Boscovich teóriáját: 1. A és B pont közötti idő-intervallumnak tényleges távolságnak kell lennie, mert csak így képesek hatni egymásra, és megfordítva, az egymástól való távolság áthidalására az erőnek időre van szüksége. Müködés közben az erő veszít nagyságából, nyugalmi állapotában pedig visszanyeri azt; hasonlóan minősége sem állandó, így maga az erő sem állandó. Így tehát az erő az idő révén hat, de ez az erő pillanatnyi; folyamatosan változik, nem létezik az időn kívül, és a saját idő-pontjának határain túl megszűnik müködni. Tehát az erő keletkezése és pusztulása az idő függvénye. 2. Ebből az következik, hogy tér és idő az erő egymással felcserélhető, egymást kizáró, inverz perspektívái. 3. Az idő-pontok Nietzschénél nem matematikai-térbeli pontok, hanem erőközéppontok, melyek csak annyiban léteznek,

\footnotetext{
${ }^{95}$ Ld. JR 12. §

96 Vö. Karl Schlechta - Anni Anders: Friedrich Nietzsche: Von den verborgenen Anfängen seines Philosophierens. F. Frommann, Stuttgart-Bad Cannstatt, 1962, s. 60-72.

${ }^{97}$ Vö. KSA 7.575, lásd a függelékben.
} 
amennyiben erőt fejtenek ki. Eközben minden pillanatban változáson mennek keresztül, tehát többé már nem „ugyanazok” az erőközéppontok: ezaz erő „,abszolút változékonysága”, melyet Nietzsche Hérakleitosz és Schopenhauer nyomán fedezett fel. Az erő természeténél fogva folyamatban van, és soha nem ugyanaz; lényege a változás, és a változás egyet jelent az időbeliséggel; ez az ún. „dinamikus világnézet” lényege. 4. Két egymással egybeeső pont között nem lehetséges hatás; minden lehetséges hatás actio in distans. 4. A taszítóerö növekedése egyenes arányban van a két pont közti távolság csökkenésével, tehát az erő nagysága „gyorsulásának” függvénye. Két pont egybeesésekor az erő „ereje” végtelen. 5. Az idő nem folyamatos, mert nincs két egymással egybeeső időpillanat, az idő működési elve tehát szintén az „actio in distans”; a tér és az idő egyaránt „diszkontinuum”. 6. Nietzsche végkövetkeztetése: a) a fennálló világot vissza lehet vezetni a tér atom-elméletére, b) ez utóbbit szintén lehetséges visszavezetni az idő atom-elméletére, tehát c) a dinamikus idő-pont és a dinamikus érzet-pont egy és ugyanaz, az idő atom-elmélete így egyúttal az érzékelés elmélete is. ${ }^{98}$ Nietzsche az általában vett materializmussal szembeni legfóbb ellenérvet látja a dinamikus szemléletben; ő ugyanis a dolgok mögött rejlő magánvaló lényeg tételezése ellen harcolt, ebben az értelemben állítja, hogy „nincs anyag, nincs akarat, nincs magánvaló dolog, nincs cél”. ${ }^{99}$ A „,materiális pontok” végtelen kombinálhatóságának lehetősége az „idő atomelméletének" dinamikus erő-törvényével kiegészülve alátámasztja a hatalom akarása és az örök visszatérés gondolatpárjának „organikus”, vagyis, mint láttuk, a teleológia-kritika értelmében „célszerütlen” koncepcióját.

Claudia Crawford érdekes adalékkal szolgál a hatástörténeti összefüggés elemzéséhez. Egyetért Whitlockkal abban, hogy a materiális pontok közti távolságok nem térbeliek, hanem viszonyszerüek, ,erővonalak”; valamint, hogy nem az idő-pontok konstituálják az időt, hanem épp ellenkezőleg, az idő az, ami csak az idő-pontokban „van”; az idő pusztán emberi találmány. E tekintetben Crawford és Whitlock erősen polemizál Keith Ansell-Pearson értelmezésével, aki szerint az idő-pontok közti távolságot matematikai pontok távolságaként, tehát folytonosságként kell érteni, így az idő nietzschei atom-elmélete a tartam egy objektív elméletének tekinthető. ${ }^{100}$ Crawford felhívja a figyelmet egy lényegi eltérésre Boscovich elmélete és a nietzschei adaptáció között, mely már Whitlock fentiekben ismertetett elemzéséből is kiviláglik: Nietzschénél, mondja Crawford, maga az erő is pontszerü, ugyanis

\footnotetext{
${ }^{98}$ Vö. Whitlock (1997) pp. 350-360.

${ }^{99}$ Vö. KSA 11.231 (,kein Stoff [Boscovich] / kein Wille / kein Ding an sich / kein Zweck.”)

${ }^{100}$ Vö. Keith Ansell-Pearson: „Nietzsche's Brave New World of Force Thoughts on Nietzsche's 1873 »Time Atom Theory« Fragment \& on the Influence of Boscovich on Nietzsche." In: Pli. The Warwick Journal of Philosophy. Vol. 9. 2000, pp. 6-35.
} 
a szilárd pontok közti hatás egy diszkontinuus ugrás következménye, nem pedig a kontinuitásé. Az erő maga az, amit az abszolút diszkontinuitásként értett távolság konstituál. Az idő atom-elmélete tehát a következőképpen elölegezi meg az örök visszatérés gondolatát: egyrészt az idöt mint a diszkontinuus idö-pontok vég nélkül gyürüzö láncolatát írja le, másrészt a tér mint egész konstitúcióját egyetlen tér-pontba visszagyürüzö mozgásként és ennek a gyürüzésnek az idő folyamatos ismétlödéseként interpretálja. ${ }^{101}$ Az idő-pontok diszkontinuumát ugyanazek a pontok tér-pontokként tagolják; így az idő maga „telik”, ellenben a tér, a konstelláció tényének értelmében, mindig Ugyanakként tér vissza. Az örök visszatérés a tér/idö örök visszatérése, amely idöként örök, és térként örökké-ugyanakkéntvisszatérő. Greg Whitlock valószínűleg jól látja a helyzetet, mikor azt állítja, a szakirodalom mostanáig messze alulértékelte Boscovich hatástörténeti jelentőségét a Nietzscheértelmezésben. Ezt a tényt próbáljuk majd a saját hasznunkra fordítani az értekezés második részében.

\section{2. Az ,aktív differencia" mint perspektíva és átváltozás: a ,szabad szellem- trilógia"}

Nietzsche tehát beteg; mind fizikai, mind szellemi értelemben. Egészségi állapota katasztrofális, lelkileg összeomlott, szellemének azonban még soha nem volt ekkora szüksége a tisztánlátásra; úgy dönt, leszámol múltja kísérteteivel, és végre azzá válik, aki valójában mindig is volt. A bázeli professzúrát és a tribscheni éveket méltatlannak érzi voltaképpeni hivatásához, az ember felszabadításához mérten. Ahogyan az Ecce homóban írja, ,az Emberi - túlságosan is emberi egy válság emlékmüve". ${ }^{102}$ A mü első részén 1878-ig dolgozott, alapját azok a feljegyzések adták, melyeket „Ekevas” címmel 1876 szeptemberétől kezdve gyüjtögetett. 1888-ban azzal magyarázza hosszú ideig tartó eltévelyedését, hogy amennyiben az ember elnyomja ösztöneit, óhatatlanul sivárságra ítéli saját magát, kiszolgáltatván a narkotikus müvészetek vonzásának. Levelezéséből nyilvánvaló, hogy nem gondolta ezt másként a mü születésének idején sem; meggyőződése volt, hogy az alapvetően „egészséges” ifjú „tudóst” a schopenhaueri metafizika és a wagneri muzsika „betegítette meg”. ${ }^{103}$ A majd’

\footnotetext{
${ }^{101}$ Vö. Claudia Crawford: „Nietzsche's Overhuman: Creating on the Crest of the Timepoint.” In: Journal of Nietzsche Studies 30. 2005, pp. 22-48.

${ }^{102} \mathrm{EH} 77 . \mathrm{o.}$

${ }^{103}$ Vö. BVN-1876, 630. („Brief an Malwida von Meysenbug.”); BVN-1876, 640. („Brief an Carl Fuchs.”); BVN-1876, 661. („Brief an Marie Baumgartner.”)
} 
egy éves sorrentói pihenő során Nietzsche kegyetlen szigorral irtott ki magából mindent, ami nem hozzá tartozott, majd szabadsága leteltével Bázelben fejezte be a könyvet 1877-78 telén. Ismert történet, hogy Nietzsche, aki mủvét Voltaire emlékének ajánlotta, küldött egy példányt Wagnernek, aki szinte ugyanekkor postázta számára a Parsifal szövegkönyvét - ez volt az utolsó „levélváltásuk”, bár Nietzsche maga inkább pengék csörrenését vélte hallani... ${ }^{104}$

Mivel elemzésünk a legszorosabb értelemben folyamatként szándékozik végigkövetni Nietzsche gondolkodásának formálódását, a „szabad szellemeknek” szóló könyvet először a két - az első, illetve a második részhez külön-külön csatolt - 1886-os Előszó nélkül olvassuk. Az első rész tehát, mely eredetileg maga volt a mü, először is a metafizika alapvető kérdéseinek abszurditását igyekszik bizonyítani; ez pedig már önmagában véve is radikális polémia Kanttal, akinél a metafizika végső kérdései jelölik ki az emberi tudás határát. Kant transzcendentális filozófiája, mint ismeretes, nem magukra a tárgyakra, hanem a tárgyakra vonatkozó ismereteinkre irányul, amennyiben ezen ismeretek tapasztalattól függetlenül, $a$ priori módon adódnak. Az érzéki megismerés kritikája során Kant meghatározza a tér és az idő fogalmait, melyek az érzéki szemlélet két tiszta formáját, a priori elvét jelentik. A tér Kant számára a jelenségek tekintetében empirikus realitással, míg a fogalmak tekintetében transzcendentális idealitással rendelkezik; tehát a külső tapasztalat vonatkozásában valós, míg attól függetlenítve, a magánvaló létezőkre vonatkoztatva (tehát transzcendentális értelemben) ideális. Az idő ezzel szemben a tapasztalás mint olyan a priori feltétele, hiszen csak az idő tételezése révén lehet fogalmunk az egyidejüségről és az egymás után következésről. ${ }^{105} \mathrm{Az}$ idő tehát minden jelenségnek, míg a tér pusztán a külső jelenségeknek a priori feltétele: „Ha a priori leszögezhetem: minden külső jelenség a térben és a tér viszonyai által a priori meghatározottan létezik, úgy a belső érzék elve alapján egész általánosan leszögezhetem: minden jelenség egyáltalán mint jelenség, azaz érzékeink minden tárgya az időben létezik, és szükségszerüen időbeli viszonyok közé kerül."106 Mind a térnek, mind az időnek pusztán egy kiterjedése lehetséges, hiszen egyiket sem tudjuk egymásutániságban elgondolni; ez a kiterjedés pedig a határtalanság, amelyből azután meghatározott tér- illetve időnagyságok határolhatók el. Az érzetadatokat a tiszta értelem kategóriái révén formáljuk meg; minden ismeretünk képzet, mely a szemlélet fogalmak alá rendeléséből származik. A tudat az appercepció szintézise révén teremti meg a képzet és a rá való reflexió egységét. A tapasztalat azonban előfeltételezi az értelem a priori kategóriáinak előzetes meglétét, melyek az ítéletek

\footnotetext{
${ }^{104}$ Ld. EH 82. o.

${ }^{105}$ Vö. TÉK 1-8. §

106 TÉK 6. $\S \mathrm{c}$ )
} 
elemi formáinak megfelelően rendeződnek el egymáshoz képest. Természetesen felmerül a két szféra, az érzékiség és az értelem közti közvetítés problémája, melyet Kant a transzcendentális sematizmushatókörébe utal. A sémák adják a hozzárendelés szabályait, méghozzá oly módon, hogy egyrészt egynemüek magával a szemlélettel, másrészt pedig $a$ prioriak és általános érvényüek. Az az a priori elv pedig, amely minden tapasztalás feltétele, mint láttuk, maga az idő; a sémák tehát időmeghatározások. ${ }^{107}$ Kant konklúziója: ha sikerül felállítanunk a par excellence tapasztalás lehetőség-feltételeinek rendszerét, azzal a tapasztalatban adódó tárgyak lehetőségét is igazoljuk. ${ }^{108}$ A valódi megismerés érzékiség és értelem együttmüködéséből ered; a metafizika végső kérdéseire, melyek a lélekre, a világegészre és Istenre vonatkoznak, vagyis nem adódhatnak a szemléletben, épp ezért nem lehetünk képesek választ adni. ${ }^{109}$ A filozófia „kopernikuszi fordulatával” Kant megkísérelte ugyan kijelölni az emberi megismerés új, szükebb határait, de Nietzsche szerint még ő sem ment eléggé messze. Kant ugyanis nem semmisítette meg magát az abszolút Igazságot, mely így tovább élt a „Ding an Sich” fogalmában, Schopenhauernél pedig „,akaratként”.

Nietzsche azt állítja, a „metafizikai világ” valóban megismerhetetlen számunkra, ez azonban semmilyen negatívumot nem jelent, mert a metafizikai pusztán negatív terminusokkal meghatározható, alapvetően „más” típusú létezés, és mint ilyen, gyakorlatilag semleges az élet szempontjából. Az, hogy egyáltalán tudomásunk van egy ennyire más világról, egyedül az álomnak „köszönhető”, de nem árt emlékeztetnünk magunkat arra, hogy az álom nem valóság - az embernek nincs két világa, csak egy: érzéseink és észleleteink eleven, empirikus birodalma. A problémát, ismétli Nietzsche A nem-morális igazságról és hazugságról szóló esszé alapgondolatát, az okozza, hogy elfelejtettük, hogy igazságaink csak metaforák, melyeket a társadalmi rend (másképpen fogalmazva: a legerősebbek uralma) fenntartása érdekében igazságként fogadtunk el; vagyis ,,igazzá hazudtuk” őket. A metafizika mint tudomány eszerint kétszeresen is téved: először önkényesen kettéválasztja a világot, majd pedig, szintén megalapozatlanul, azt állítja, hogy szubjektív képzeteink tökéletesen

\footnotetext{
${ }^{107}$ Vö. TÉK 172-178.. o. „A tiszta értelmi fogalmak sematizmusáról.”

${ }^{108}$ Vö. TÉK 264-265. o. „Ha tehát azt mondjuk, hogy az érzékek úgy állítják elénk a tárgyakat, ahogyan ezek megjelennek, míg az értelem úgy állítja elénk őket, ahogyan vannak, az utóbbi állítást nem transzcendentális, hanem pusztán empirikus értelemben kell felfognunk, mint ami a tapasztalat tárgyairól a jelenségek átfogó összefüggésében ad képzetet, s nem úgy tárja elénk a tárgyakat, ahogyan a lehetséges tapasztalattal $\mathrm{s}$ következésképpen az érzékekkel való bármiféle viszonytól függetlenül, vagyis a tiszta értelem tárgyaiként létezhetnek. Mert az utóbbi módon soha nem ismerhetünk meg tárgyakat, mi több, azt sem tudhatjuk, lehetségese egyáltalán efféle transzcendentális (rendkívüli) megismerés, legalábbis olyan, amely szokásos kategóriáinknak rendelődik alá. Az értelem és az érzékek a mis esetünkben csak egymással összekapcsoltan határozhatnak meg tárgyakat."

${ }^{109}$ Az ún. „transzcendentális ideákról” és a velük kapcsolatos tévedésekről lásd: TÉK 306-319. o.
} 
képesek reprezentálni a rajtunk kívül, tőlünk függetlenül létező dolgok úgynevezett „lényegét”. Bár alapösztönünk az igazság utáni kutatás, ${ }^{110}$ be kell látnunk, hogy a metafizika természeténél fogva irreleváns az élet szempontjából; ítéleteinkben nyoma sincs a megalapozottságnak vagy logikának: ezek mind nagyon is, túlságosan is emberi dolgok. A legelemibb ítélet alapja ugyanis az élvezet, vagy éppen a fájdalom tisztán fizikai érzete, ettől kezdve az adott dolog mindig ugyanazt a hitet kelti életre bennünk - mintha bizony a világ rajtunk kívül álló része öröktől-örökké változatlan lenne. Szilárdan hiszünk a szabad akaratban, melynek révén az okozatiságnak ezt az alapmodelljét a világ egészére alkalmazhatjuk, mely így számunkra többé már nem káosz, hanem logikusan rendezett, kétpólusú (ti. szubjektív és objektív) univerzum. Nietzsche szerint tehát a metafizika mint olyan csakis a szabad akarat „szubsztanciájának” feltalálása folytán vált lehetővé, amely visszavezethető az önmagával azonos szubsztancia alapgondolatára, mely utóbbi pedig egyszerüen megismerési ösztönünk eredménye - erről azonban már régóta tudjuk, hogy csak az életösztön másik neve. Úgy tủnik tehát, mondja Nietzsche, hogy igazságösztönünk ellenére gondolkodásunk természetéből adódóan logikátlan, ennél fogva pedig szükségszerüen igazságtalan is; ez a tény pedig az ember-lét legnagyobb paradoxona, „a létezés egyik legnagyobb és legföloldhatatlanabb diszharmóniája". ${ }^{111}$

A jó és a rossz, mint egymással szemben álló érték-fogalmak, maguk is egy szembeállásból származnak: a hatalmon lévők és az elnyomottak oppozíciójából. Mindkét fél felveszi a jó és a rossz fogalmát, az eltérő pozíció azonban az értékelésben is eltérő eredményre vezet. Az erősek és nemesek a többi erős és nemes embert tartják jónak, függetlenül attól, hogy az adott esetben akár az ellenfelük is lehet; a többieket pedig alacsonyabb rendünek, hitványnak - ők tehát közösen alkotnak egy értékrendet, és ennek megfelelően mérik a világot. Az igazságosság fogalmát például a méltányosság és a viszonosság fogalmaival definiálják, végső soron tehát a csere terminusaiban gondolják el. A nekik alárendelt ember viszont mindenhonnan támadást vár, számára tehát bármi lehet rossz,

\footnotetext{
${ }^{110}$ Vö. EE I:27. § „Az »intellektuális lelkiismeretnek« nevezett különleges jelenség gyökere abban a tényben rejlik, hogy saját gondolatainktól, fogalmainktól, tanainktól félünk, ugyanakkor azonban tiszteljük is önmagunkat bennük, önkéntelenül eröt tulajdonítunk nekik, tanulunk tölük, megvetjük, dicsőítjük és hibáztatjuk öket, tehát úgy viselkedünk velük, mintha szabad szellemi lényekkel, független hatalmakkal érintkeznénk, vagyis úgy bánunk velük, mint egyenrangú féllel. - Itt is az történt, hogy egy vadhajtásból a legmagasabb rendü morális termés lett."

${ }^{111}$ EE I:32. § „Igazságtalanságra szükség van.” Danto olvasatában Nietzsche 1878-ban még nem feltétlenül látta az összefüggést aközött, amit az általában vett emberi természetről filozófiai értelemben mondott, és amit a túlságosan is emberi dolgokról az aforisztikus pozíciójából írt. A két, kései Előszó idején (1886) azonban már tudta, hogy a filozófiai tévedések a tévedések egy speciális fajtáját képezik: méghozzá annak révén, ami bennük emberi - nem túlságosan is, hanem általában véve; mivel nincs Igazság, nincs „tévedés” sem, csak „emberi”. (Vö. Arthur C. Danto: Nietzsche as Philosopher. Columbia UP, New York, 2005. p. 240.)
} 
még az is, ami jónak látszik, és képtelenek közösséget teremteni; tehát nyilvánvaló, hogy társadalmunk az előbbi mintát követi. Azonban, mondja Nietzsche, előbb-utóbb minden metafora igazsággá szilárdul; éppen ez történt erkölcsi világrendünkkel is. De ha mindezt felismerjük, meginog az egész szerkezet, és onnantól kezdve egyedüli célunk csak az lehet, hogy újraépítsük világunkat, a lehető legstabilabb alapokra - újfajta alapokra, miután az Igazságról kiderült, hogy nem létezik. Az ilyen rideg, céltudatos munkához fontos megőriznünk hidegvérünket, és metafizikusból pszichológussá kell válnunk; abban az értelemben, ahogyan Nietzsche még a pszichológia önálló tudománnyá válása előtt értette, érthette ezt. A hétköznapi, nagyon is emberi dolgok vizsgálatából kell megalkotni az ember tudományát, figyelembe véve önmagunk és legfőbb értékeink történeti, azaz időbeli természetét. ${ }^{112}$ Észre kell vennünk, hogy az általunk „erkölcsösnek” hitt döntéseink mélyén ösztöneink dolgoznak; hogy ugyan alárendeljük valamely vágyunkat, de épp egy másik vágyunknak - voltaképpen feláldozzuk önmagunkat, mint individuumot. ${ }^{113}$ Az ún. „,erkölcs” számunkra csak tanulható, ösztöneink ugyanis egészen mást diktálnak; a morális cselekedet nem az ember természetéből fakad. Felebarátom iránti részvétem nem ösztönös, csak igen sok gyakorlás árán tanulhatom meg beleélni magam az ő fájdalmába, de mi ketten sohasem érezhetjük ugyanazt.

A vallási kultusz alappillére a hamis interpretáció. A tölünk teljesen idegent, az érthetetlent misztifikálja, olyan törvényeket kényszerítve a természetre, melyek tőle a lehető legtávolabb állnak; emberi világunk így lakályos lesz, de csak egy bizonyos határig: ami azon túl van, az a számunkra érthetetlen és megfoghatatlan szentség birodalma. A szent a megfelelö interpretáció segítségével megjeleníti számunkra az igazságot, kijelöli a legfőbb értékeket, és a boldogságot ezen értékek elérésével teszi egyenlővé. A görög világ hatalmas előnye a kereszténységgel szemben, hogy ott a kultikus tevékenység az életöröm növelését szolgálta, a kereszténység ezzel szemben az eredendően bünös létezés tudatának felvállalásától tette függővé magát az emberi közösséghez való tartozást is. (De azt se felejtsük el, mi volt ez a bizonyos eredendő bün...)A görög szellemből még megőriztek

\footnotetext{
112 Morális értékeléseink történeti természetének hangsúlyozása kapcsán szokás kitérni Nietzsche és az evolucionizmus viszonyára. Érdekes, hogy az Emberi - túlságosan emberi a Rée-vel való barátság, és utóbbi Psychologische Beobachtungen című írásának Nietzsche gondolatmenetére bevallottan gyakorolt hatása ellenére sem tartalmazza a moralitás biológiai értelmezését, a „moralitás fiziológiája” csak évekkel később, a Hajnalpírban kerül kifejtésre. Nietzsche egyetért Rée-vel abban, hogy értelemmel felfogható világ nem létezik, de azt már nem fogadja el, hogy moralitás hajlama és képessége az ember altruista természetében gyökerezne. (Vö. Safranski [2002] 155.156. o.) A radikális teleológia- és metafizika-kritika egyértelmüen a klasszikus evolucionizmussal szembeni állásfoglalásnak tekinthető. Erről bővebben ld. Gregory Moore: Nietzsche, Biology and Metaphor. Cambridge UP, Cambridge, 2004, pp. 58-62.

${ }^{113}$ Vö. EE I:57. § „A morálban az ember nem individuumként, hanem dividuumként kezeli önmagát.”
} 
valamit a müvészek, nekik jóval kevesebb érzékük van az igazsághoz, mint a morális-vallásos embereknek; de talán inkább úgy fogalmazhatnánk: ők nem az igazság, hanem a szép látszat felé elkötelezettek, az igazság számukra csak egy eszköz a valóság meghamisítására, számunkra-valóvá tételére. A müvészek játszanak az élettel, szándékosan hazudnak róla, de az alkotásban mégis van valami véletlenszerü. Nietzsche szerint azonban ezt a fajta hamisítást csak a felszínesebb, súlytalan érzelmeken lehet elkövetni; az élet voltaképpeni, tragikus mélységü problémáiból aligha születnek műalkotások. A művészetnek eredeti értelmében szintén az életöröm növelése volt a célja, és ez az eredeti képesség tovább él bennünk, még a müvészet megszünte után is. Most, a metafizikai igazságok, az erkölcsi világrend, és az ezeknek alávetett müvészet lerombolásakor az életerő, mely mindezek hátterében szunnyadt, minden eddiginél tisztább és szabadabb formában törhet elö: ezt jelenti a szellem felszabadítása.

A mü két évvel később megjelenő második részéből számunkra most azok az aforizmák lesznek különösen fontosak, melyek valamilyen módon a perspektivikus világnézetre vonatkoznak. Fontos megjegyezni, hogy Nietzsche nem megszüntetni, hanem újradefiniálni akarja az igazság fogalmát, figyelembe véve gondolkodásunk és értékítéleteink alapvetően logikátlan és igazságtalan voltát. ${ }^{114}$ A perspektivizmus koncepciója egyrészt egyenes következménye a metaforikus igazság gondolatának, illetve az emberi létezés radikális időbelisége belátásának. Van azonban egy ennél jóval konkrétabb, sajnos azonban túl ritkán hangsúlyozott jelentősége is, méghozzá a különbség aktivizálása révén kifejtett konstitutiv mozgás elinditása. ${ }^{115}$ Ezzel kapcsolatban feltétlenül hivatkozhatunk Gilles Deleuze-re, akinek olvasatában a nietzschei gondolkodás a par excellence differenciafilozófia, és mint ilyen, az azonosság diszkreditálásában talál magára. A perpektivizmus egy ilyen gondolkodás egyedül lehetséges látásmódja, mely folyamatosan kifejezi és újratermeli a minden értelem belsejében folyamatos változásban, átrendeződésben lévő hierarchiát, minek következtében tehát az értelem kizárólag temporális komplexumként jelenhet meg. Az értékelés mindig akció, cselekedet, a differencia müködése, melynek következtében a „valóság” összetett és folyamatosan formálódó erőtér. Korábban láttuk, hogy erkölcsi döntéseink hátterében is az ösztönök küzdelme zajlik; az erösebb győz a gyengébb felett, és ezt a győzelmet mi a magunkénak, szabad akaratunk aktusának tekintjük. Az értelem, mint amely természeténél fogva emberi produktum, ugyanezen elv szerint alakul, az erők harcának

\footnotetext{
114 Vö. Biczó Gábor: „A morál és az igazság »halála«.” In: Gond, 1999/18-19. 322-337. o. Online: http://www.c3.hu/ gond/tartalom/18-19/frabiczo.html

${ }^{115}$ Vö. Deleuze (1999) 16-23. o.
} 
pillanatnyi állását tükrözve. Az erők hatásaikban válnak láthatóvá, a hatás maga az akarat, ami pedig lehetővé teszi: a távolság [Distanz]. A „distancia pátosza” tehát az önmagát akaró különbség akarása, az akarat maga. A perspektíva ugyanis mindig horizont, mindig lehatárol és meghatároz, de olyan müködés révén, melynek nincsen arkhimédeszi pontja; a perspektivikus megismerés a „szabad szellem” sajátja, aki először eltávolodik a megismerni kívánt dologtól, elmozdítván a perspektívát, majd visszatér ahhoz, de a nézőpont-eltolódás miatt az a dolog már nem ugyanaz, mint ami addig volt. A „szabad szellem” önmagának teremt igazságot, amely azonban nem szubjektív igazság, mert a vizsgálódó szubjektum perspektívája pedig folyamatosan változik, és vele változik a dolog képe is - ez a filozófia „kopernikuszi fordulatának” végső következménye. Ugyanez érvényes az önmaga után kutató szellemre is, az ő esetében azonban többről van szó, mint önismeretről, hiszen ő maga a vizsgált dolog, mely a perspektívateremtő távolságból más képet mutat, amely megváltozott képhez az immáron szabaddá vált szellem „visszatér”. Richard Schacht szerint a „szabad szellem-trilógia” (vagyis az „szabad szellemeknek” szóló könyv, a Hajnalpír, valamint $A$ vidám tudomány) nem puszta átmenetet jelentenek a Zarathustrához, hanem különös jelentőséggel bírnak az életmüben, éppen az örök visszatérés, valamint a hatalomakarás gondolatának megelölegezése révén. ${ }^{116}$ Jegyezzük meg, hogy Nietzsche ekkor talált rá az újfajta érzékenységéhez illő írásmódra, az aforisztikus stílusra is, mely önmagában, plasztikus erővel szemlélteti a metafizika és a perspektivizmus közti különbséget: az aforisztikus, töredékes beszédben nincs ellentmondás, mivel a töredékek nincsenek egymással kapcsolatban, hanem egymás után, egymás mellett állnak. A töredék nem állít, nem tagad, hanem folyamatosan különbözik, ő maga a mozgásban lévő határ. ${ }^{117}$

Eddig tehát a mü szoros olvasata, most pedig következzen egy-egy részlet a két, 1886os Elöszóból, kommentár nélkül:

\footnotetext{
${ }^{116}$ Vö. Richard Schacht: „Nietzsche: Human, All Too Human.” In: Introductions to Nietzsche. Ed. Robert R. Pippin. Cambridge UP, Cambridge, 2002, pp. 91-111. Ugyanezen a véleményen van Biczó Gábor is, aki szerint a perspektivizmus Nietzsche bölcseletének kulcsmomentuma, mint a keletkezés folyamatának vizsgálatát lehetővé tévő szemléletmód, mely már implicite tartalmazza az örök visszatérés gondolatát. „A keletkezés szubsztanciális alapja az a tény, hogy minden világrajövetel lényege az életből való részesedésként jelenik meg, vagyis a különböző dolgok keletkezése ontológiai értelemben egyféle. [...] Az individuális élet mint perspektíva a keletkezés pillanatában nyer lehetőséget életének megítéléséhez." (Vö. Biczó Gábor: A tragédia délelőttje. Az ifjú Nietzsche filozófiai perspektivizmusa. Osiris, Bp., 2000. 44-45. o.)

${ }^{117}$ Vö. Blanchot, Maurice: „Nietzsche és a töredékes írás.” Ford. Ádám Anikó. In: Athenaeum, 1992. I/3. A francia Nietzsche-recepció. 56-77. o., különösen 60-61. o. „... ezúttal együtt van a filozófia, s ami nem elégszik meg a filozófiával. [...] A pluralizmusnak tehát két fajtája van. Az egyik a kétértelmüség filozófiája, a sokrétű lét tapasztalata, a másik az a különös sokféleség, mely nem plurális és nem egységes. A töredékes beszéd sokfélesége ez, a nyelv provokációja, amely még akkor is beszél, mikor már minden elmondatott. [...] a lét $-a$ lét egysége és azonossága - visszavonul..." (kiemelés tőlem, L. E.)
} 
Rendeltetésünk uralkodik rajtunk, akkor is, ha még nem ismerjük; jövőnk adja meg jelenünk szabályát. Ha mi, szabad szellemek, a rangsor problémájáról mondhatjuk el, hogy ez a mi problémánk, akkor most, életünk delén, értjük meg először, hogy a problémának milyen előkészületekre, kerülőutakra és álöltözetekre volt szüksége, mielött egyáltalán fölmerülhetett, és hogyan kellett tapasztalnunk első ízben a lélek és a test legellentmondásosabb és legsokrétübb ínségét és boldogságát, nekünk, azon belsö világ kalandorainak és világutazóinak, amely belső világ neve »ember«, nekünk, minden ugyancsak emberi »magasság« és »különbség» felméröinek - mindenütt sürgölődve, szinte ijedelem nélkül, nem nézve le semmit, nem tévesztve semmit szem elöl, felbecsülve mindent, megtisztítva mindent a véletlenszerü elemektöl, mintegy megszürve öket, amíg végre mi, szabad szellemek, azt mondhattuk: »Ez itt egy új probléma! Hosszú létra az, amelynek fokaira fölmásztunk, leültünk rá, valamikor mi magunk voltunk ezek a fokok! Van itt magasság, mélység, meghatározott rend, rangsor, amelyet jól látunk: itt van a mi problémánk! « ${ }^{118}$

Végül pedig meg kell fogalmaznom tételemet a romantikus pesszimizmus ellenében; azaz a nélkülözők, szerencsétlenek, legyőzöttek pesszimizmusával szemben: létezik egyfajta akarat, a tragikum, a pesszimizmus akarása, amely legalább annyira a szigorú, mint az intellektuális erő (ízlés, érzelem, lelkiismeret) jele. Ilyen akarattal a lélekben nem félünk a szörnyüségestöl és a kérdésestöl; amely minden létezés sajátja, hanem egyenesen elébük megyünk. Az efféle akarat mögött bátorság van, büszkeség, valamely nagy ellenség utáni vágy. - A kezdet kezdetétöl ez volt az én pesszimista perspektívám és azt hiszem, ez új perspektíva. E pillanatig ehhez tartom magam. És - hiszitek-e vagy sem - nem csupán a saját érdekemben, hanem alkalomadtán - érdekeim ellenére. $^{119}$

A későbbiekben részletesen tárgyalt heideggeri kritika szerint az örök visszatérés-gondolat a hatalom akarása koncepciójában teljesedik ki: a hatalom akarása az ontológiai differencia elfelejtése révén lesz a keletkezés léte, hiszen az örök visszatérés pillanatában döl el, mire mondunk igent. Nietzsche eszerint pontosan azért nem tudta meghaladni a metafizikát, mert ő maga is „létfelejtésben” volt. A felkészült Nietzsche-értelmező számára nem lehet kérdés, hogy a hatalom akarása funkcióját tekintve minden keletkezés operatív ereje, az örök visszatérés affirmációja pedig a változást a létbe hozó igenlés. A nietzschei perspektivizmus figyelmes elemzése azonban azt a meggyőződésünket látszik alátámasztani, hogy az ekkor még csak implicit módon jelenlévő két alapgondolat nem az alárendelés, hanem a szimbiózis viszonyában áll egymással. Kettejük együtthatásának eredménye a „szabad szellem”, aki túl van az igent/nemet mondás kényszerén, mivel pontosan tisztában van igazságainak

\footnotetext{
${ }^{118}$ EE I:Előszó. 7. §

${ }^{119}$ EE II:Előszó. 7. § (kiemelések tőlem, L. E.)
} 
perspektivikus jellegével. Pesszimizmusa mégsem a legyőzötteké, hanem a bátraké, akik vállalják a minden döntést megelőző bizonytalanságot; ${ }^{120}$ magát a választást választják, kimondva ezzel azt az első igent, ami helyet biztosít minden további akarás számára. Azonban az ontológiai differencia nem oldódik fel, hanem éppen, hogy aktivizálódik: a változás igenlése a különbség igenlése, melynek folyamatos elevensége az az állandó, de állandóságában megállás nélkül differenciálódó eleme, mely örökké visszatérve nem a létet, hanem a keletkezést, vagyis a különbséget hozza a létbe újra és újra. A „szabad szellemtrilógia" és az örök visszatérés gondolata közti összefüggéseket lényeglátóan tárgyalja Howard Caygill tanulmánya. Caygill hangsúlyozza: bár az örök visszatérést nehéz egyértelmüen pozicionálni az életmüben, az kétségtelen, hogy a gondolat egyenes következménye a „szabad szellem trilógiának”; az örök visszatérés nem a megoldása a szellem felszabadítása problémájának, hanem annak bejelentése, kinyilatkoztatása. Az értelmezés a szellem felszabadításának probléma-jellegéből indul ki; a második részhez írott Elöszó német szövegben több helyen is elhangzik ezzel kapcsolatban a „feladat” [Aufgabe] kifejezés. A „feladat” (ti. a szellem felszabadítása) visszatérése a legnagyobb ajándék, hiszen a „feladat” maga a folyamat és a folyamat célja egyszerre. A „feladat” a bennünk lévő zsarnoki erő, aminek a jelenlétét állandóan érezzük, mégsem tudunk neki nevet adni - csak a visszatérésben tudjuk megnevezni, akkor pedig már túl késő. A „feladat” hívása kényszerítő erejü; ezzel kezdődik a „rangsor problémája”, és a már mindig is ott lévő a visszatérésben valóban létezővé válik. A szabad szellem azért mond igent a minden későbbi választást megalapozó döntésre, mert belátja, hogy a mértéktelenséghez mértékre, a különbséghez azonosságra van szükség. Az erőszak eme tettéért azonban meg kell fizetnie; büntetése pedig maga a döntés. Hiszen a döntés maga már mindig igazságtalan azzal szemben, akit vagy amit nem választunk, mert a döntésnek ebben az igent/nemet megelőző pillanatában semmilyen szerepet nem játszik a racionalitás; így válik a túlságosan-is-emberi: emberfelettivé. ${ }^{121}$ Úgy tünik, a különbség aktivizálása itt is a legerősebb fegyvernek bizonyul. ${ }^{122}$

\footnotetext{
${ }^{120}$ Vö. Georges Bataille: „Nietzsche és a tilalmak áthágása.” Ford. Somlyó György. In: Athenaeum, 1992. I/3. A francia Nietzsche-recepció. 42-55. o. Bataille szavaival Nietzsche nem pusztán semmibe vette a határokat, hanem tudomásul vette öket, és tudatosan szegte meg azokat: tudta, hogy az öntörvényüség paradoxonában ,,a sértés egybeforr a hódolattal (...), tudta, hogy aki erre vállalkozik (...) annak a lábai előtt csak a semmi tátong.” (U. ott 53. o.)

${ }^{121}$ Vö. Howard Caygill:,Affirmation and eternal return in the Free-Spirit Trilogy.” In: Nietzsche and Modern German Thought. Ed. Keith Ansell-Pearson. Routledge, London-New York, 1991, pp. 216-239. Caygill szerint a „szabad szellem” nem illogikus, hanem alogikus; túl van a logikus/illogikus, jó/rossz, stb. megkülönböztetésén, büntetése maga a „feladat”: hogy felismerve ezeket az ellentéteket, a rajtuk való túllépéssel diszkreditálja őket. „The free spirit must affirm a judgement which warps and displaces, is unjust, one which would normalize originality, measure the immeasurable, compare the incomparable, and identify the different. And it must do so because it recognizes that there can be no originality without norm, no immeasurable without measure, no
} 
Nietzsche szemében a „német tisztesség és jámborság” utolsó maradványai az „,intellektuális becsület” fogalmában sürüsödnek össze; „ez az utolsó morál, amely még nekünk is hallatja szavát, amelyet még meg tudunk élni”. Kérdéses létezés az ilyen, mert a pesszimizmus végső határáig hajtja, élvezi és akarja a tagadást; véghezviszi „a morál önmegszüntetését". ${ }^{123}$ Nietzsche már megírásakor nagy jelentőséget tulajdonított a Hajnalpírnak, melynek alapgondolatai saját bevallása szerint a genovai tengerpart sziklái között bóklászva, a tenger titkait hallgatva fogantak 1880-81 telén. A mű ennek ellenére szinte észrevétlen maradt, alig pár példány fogyott belőle. A megelőző nyáron Nietzsche már megváltásként várta a halált, az ezután következő hónapokban-években bekövetkező váratlan javulást pedig szinte égi jelnek vélte. A Hajnalpír és a Vidám tudomány tartalmilag az Emberi - túlságosan is emberi egyenes következménye, nyelvezetüket tekintve viszont egyre „egészségesebbek”, egyre „vidámabbak”. Arthur C. Danto szerint a Hajnalpír szinte megvalósítja önmagát, a kortárs „filozófiai pszichológia” csak mostanában kezdett felzárkózni Nietzsche gondolkodásához. Nietzsche technikáját Danto „mély interpretációnak” nevezi; melynek segítségével azt vizsgálja, hogy mélyen, az erkölcsi lény álcája alatt milyen folyamatok zajlanak az emberben. A morál voltaképpen annak az erőnek (később: a hatalom akarása) a neve, amely egyfajta formulaként szolgál, ami szerint az egyén a többieket és önmagát is értékeli - az öninterpretációnak ez a mozzanata beékelődött közénk és az önmagunkról való tudásunk közé. Az Előszó 4. aforizmájának utolsó mondata: „Bennünk megy végbe, ha mindenáron képletet akartok hallani, »a morál önmegszüntetése«”. Az „önmegszüntetés” kifejezés az eredeti szövegben „Selbstaufhebung”; ${ }^{124}$ a hegeli dialektika klasszikus terminus technicusa, mely egyszerre jelenti az adott dolog megszüntetését, megőrzését és transzcendálását. Nietzsche tehát ezzel a módszerrel voltaképpen a saját farkába haraptatja a dialektika kígyóját... ${ }^{125}$

incomparability without comparison, no difference without identity. There is a necessary violence and injustice in judgement which manifests itself in law. But it is open to the judgers to recognize this violence and to pay penance for it, and this is what is more than human." (Caygill [1991] pp. 230-31., kiemelés tölem, L. E.)

${ }^{122}$ Vö. EE II:67. „A megszokássá csontosodott ellentét. - Az általában pontatlan megfigyelés a természetben mindenütt ellentéteket lát (mint pl. »meleg és hideg«), ahol nem ellentétek vannak, hanem csupán fokozati különbségek. Ez a rossz szokás vezetett minket félre, ezért igyekszünk a belső világot, a szellemi-erkölcsi világot ezen ellentétek alapján fölfogni és tagolni. Elmondhatatlanul sok érzékenység, követelőzés, keménység, elidegenedés, elhidegülés vert gyökeret az emberi lélekben, amiért tévesen ellentéteket látott ott, ahol átmenetek voltak."

${ }^{123}$ H Elöszó, 4. $\S$

${ }^{124} \mathrm{KSA} 3.16$

${ }^{125}$ Vö. Danto (2005) pp. 245-250., különösen p. 249. „In the great prime of his literary prowess, Nietzsche's prose suggests the performative assurance of a marvelously gifted and intuitive lover. The text of Morgenröte, with its sudden shifts of rhythm and tone, at one moment lyrical and at the next moment earthy, its mock distance and its sudden intimacy, its sweeping playfulness, its jeers, sneers, jokes, and whispers-and its abrupt 
A Hajnalpírban Nietzsche maliciózus hangnemben mér megsemmisítő csapást a „morálba vetett bizalmunkra”. Maudemarie Clark és Brian Leiter felhívja a figyelmet Nietzsche kettős stratégiájára: egyrészt a morális előfeltevésekkel az ember naturalisztikus képét szegezi szembe, akinek cselekedeteit nem elvont, metafizikai ideálok, hanem fiziológiai-pszichológiai tények irányítják. Másrészt, ahogyan azt már a korábbi írásokban is tette, az életet gyengítő tényezőként mutatja fel a morált; az erkölcsi lény híján van mindannak ez emberi kiválóságnak és nagyságnak, melynek révén egy erős civilizáció alappillére lehetne. A kritika nem a moralitásba vetett hit ellen irányul, hanem azokat az előfeltevéseket cáfolja, melyek egyáltalában megalapozhatnak bármiféle moralitást - vagy éppen immoralitást. Az első ilyen preszuppozíció felteszi, hogy morális döntéseink tudatosak, mivel ismerjük cselekedeteink okait és következményeit. Nietzsche ezzel szemben azt állítja, döntéseinket az ösztönök irányítják, egészen pontosan a legerősebb, győztes ösztönök; és maga küzdelem, az ösztönök különbözősége és harca teszi az embert morális lénnyé. A második előfeltevés, hogy morális értékeinket a szokás [Sitte] és a használat során eltelt idő határozza meg, ilyen módon a moralitás [Sittlichkeit] nem más, mint a tradíciónak való engedelmeskedés. A szokás iránti tiszteletnek oka egyfajta irracionális, primitív félelem az egész közösséget érintő, természetfeletti büntetéstől; vagy még inkább, a természetfelettitől magától. Mindez azért lehetséges, mondja Nietzsche, mert alapjában véve irracionális lények vagyunk - itt van hát az ideje, hogy újfajta módon gondolkodjunk és értékeljünk, felszabadulván a metafizikai és morális elöítéletek súlya alól. ${ }^{126}$ Az emberi civilizáció története a dolgok feletti uralmunk kiterjesztésének története, az erkölcsös cselekedetben rejlő élvezet mögött egy jóval alantasabb és eredetibb érzés rejtőzik: a „kitűnés moralitása”, a „kifinomult kegyetlenség kéje”. ${ }^{127}$ Szükséges tehát egy új, őszinte és egészséges önbecsülés, jó lelkiismeretü, „délvidéki” egoizmus kialakítása, mely már nem szorul az erkölcsi emelkedettség vigaszára, ${ }^{128}$ hanem megelégszik önmagával. A lélek testtel szembeni elsőbbségének gondolata nem egyszerűen hiba, hanem hazugság; a test „lelkesítése” a

\footnotetext{
unanticipated kills-is a kind of eroticism of writing, and it requires of its reader a partnership in pleasure and intelligence. Nietzsche's voice has lost the professorial authority of the early writing and has not yet acquired the strident conviction of a prophet unheeded. And in none of his books, I feel, is there a more palpable sense of spiritual well-being. Morgenröte was put together at an especially quiet moment in Nietzsche's life."

${ }^{126}$ Vö. Maudemarie Clark - Brian Leiter: „Nietzsche: Daybreak.” In: Introductions to Nietzsche. Ed. Robert R. Pippin. Cambridge UP, Cambridge, 2002, pp. 117-136. (Vö. H 103, 115., 116., 119. §, illetve EE:I. 57. §)

${ }^{127}$ H $30 . \S$

${ }^{128}$ Vö. H 49. § „Az új alapérzés: végleges mulandóságunk. - ... A keletkező lét maga után vonszolja a volt létet: miért is lenne kivétel valamely csillagocska és rajta egy fajocska ezen örök színjáték alól! Félre az efféle érzelgősséggel!” Emlékezzünk a preszókratikusokról szóló korai szöveg Hérakleitosz-laudációjára: „Mostantól örök szemlélöi vagyunk annak, amit ő észrevett, a keletkezésben megnyilvánuló törvény és a szükségszerüségben rejlö játék tanának. Ö húzta fel a legnagyobb szinjáték függönyét.” (FGTK 97. o, kiemelések tőlem, L. E.)
} 
metafizikai-erkölcsi világrend fenntartásának alappillére: ennek révén lehet ugyanis engedelmességre bírni az immáron „lelkes”, tehát morális lényt. Eközben minden emberi cselekedet oka az ösztön, konkrétabban a kémia, a fiziológia: „egy csepp túl sok vagy túl kevés vér az agyunkban [...] ama csepp okozza szenvedéseinket". ${ }^{129}$ A metafizika feltalálta a túl-világot, melynek talaján aztán felépülhettek a moralitás és a vallás bástyái; mindezt pedig azért tehette meg, mert az ember alapjában véve tudatában van saját végességének, és retteg tőle. Hiába adtunk etikai, vagy vallási jelentőséget az életnek, ezt csak saját fennmaradásunk érdekében tettük, nem pedig azért, mert bármi okunk lenne feltételezni, hogy Isten, a feltétlen erkölcsi törvények, és általában véve maga a túl-világ - valóban léteznek is.

„Új érzékenység” kell, melyre aztán az értékelés új módját alapozhatjuk. Voltaképpen egész emberi világunkat mi teremtettük olyanná, amilyenként tudomásunk van róla, és ahogyan már láttuk, a kauzális gondolkodás is eredendő tévedésen alapul; azon ugyanis, hogy egymás után következő dolgok képeinek látványából okra és okozatra következtetünk, és hiszünk a célszerüségben, mely az egész folyamat motorja. Rég elfelejtettük már, hogy igazságaink csak metaforák, azt hisszük, hogy szavaink pontosan kifejezik az általuk jelölt dolog lényegét, holott nem teszünk mást, mint önmagunk képére formáljuk őket. ${ }^{130}$ Vajon hogy nem vettük észre, hogy a kauzalitásnak és teleológiának alárendelt világban sosem lehet igazán szabad az akarat? Akarni csak és kizárólag a szükségszerüt akarhatjuk, uralkodni tehát csak saját akaratunkon szükséges. Mostanáig csak a másikhoz képest határoztuk meg magunkat: ${ }^{131}$ én az vagyok, aki a többiek szemében te, ő, és így tovább, saját magunk számára mindeddig kimondhatatlanok voltunk; ez azonban azt is jelenti, hogy bár a rajtunk kívül eső világot már szinte teljesen számunkra-valóvá tettük, mégis van valami, ami mindig ott motoszkál a fejünkben, mégsem tudjuk nevén nevezni. ${ }^{132}$ Ahogy korábban említettük, Nietzsche a szellem felszabadítását önteremtésként értette, ezt tekintve az egyetlen igazi

\footnotetext{
${ }^{129} \mathrm{H} 83 . \S$

${ }^{130}$ Ld. H 117. § „Ülünk a hálónkban, mi, pókok, és bármitis fogunk benne, az semmi más nem lehet, mint ami éppen a mi hálónkban megfogható." A pók-hasonlat többször is előkerül majd a Zarathustrában is

${ }^{131}$ A felebarát, vagyis a Másik problémáját Caygill a Hajnalpír 118. aforizmájára hivatkozva a határ kérdésével kapcsolja össze, és Blanchot-hoz hasonlóan úgy véli, hogy a köztem és a Másik (tehát a „világ” tetszőleges mennyisége, L. E.) között húzódó határvonal nem az ellentét terminusait müködteti, nem kívül vagy belül vagyunk rajta. A határ mindig meg-határoz: belénk vésődvén nyomot hagy bennünk, egyszerre van tehát rajtunk kívül és belül, meghatározván perspektívánkat. Caygill konklúziója, hogy Nietzsche filozófiájának „igenlő” része, vagyis a „szabad szellem-trilógia” voltaképpen az ellentétek hálózataként felfogott értékelésmód összeomlására épül; ennek ugyanis két lehetséges következménye adódhat: a nihilista igen/nem, vagy pedig az „érték” mint olyan meghaladása a „szabad szellem” korlátlan ,,igen”-je révén. (Vö. Caygill [1991] pp. 232-234.) ${ }^{132}$ Itt ismét hivatkozhatunk Rüdiger Safranskira, aki az individuumot az „irdatlanhoz” hasonlítja, egészen pontosan - alkalmasabb kifejezés híján - azonosítja a kettőt, lévén mindkettő kimondhatatlan: megnevezhetetlen, befoglalhatatlan, minden kor minden részletében jelenlévő, de mégsem egységes. (Vö Safranski [2002] 190-200. o.)
} 
kihívásnak, ${ }^{133}$ melynek életünk során meg kell felelnünk. Bátornak, vagy még inkább nagylelkünek kell lennünk: le kell mondanunk a birtokunkban lévő bizonyosságokról, végső soron önmagunkról; vállalnunk kell az „előzetes vagy utólagos létet élünk”, ${ }^{134}$ kísérletté kell válnunk, akarnunk kell azzá válni, és önmagunknak ebben a folyamatos kockára tételében és eltékozlásában „második természetünk” „felszíne alatt megérik első természetünk”. ${ }^{135}$

1880-81-ben Nietzsche nagyon sokat utazik, leginkább barátja, Heinrich Köselitz társaságában. Sok időt tölt Genovában, főleg az őszi-téli hónapokban; a hirtelen jött egészség és a tengerpart friss levegőjének hatása a Hajnalpír, és különösen A vidám tudomány hangulatát is markánsan meghatározza. Fontos azonban megjegyeznünk, hogy 1881 augusztusában Nietzsche Sils Mariába utazott, és ott, a svájci Alpok egyik sziklájának magasában Zarathustra végre rátalál a filozófusra, ${ }^{136}$ aki 1881. augusztus 14-én így ír Peter Gastnak:

Láthatáromon gondolatok magasodnak, amilyeneket még sosem láttam - róluk semmit sem akarok elárulni, és én magam is a rendíthetetlen nyugalom állapotában kívánok maradni. [...] Előző nap vándorlásaim közepette minden alkalommal sírtam, de nem ám holmi szentimentális könnyeket, hanem felcsukló zokogással sírtam. Közben énekeltem, ostobaságokat fecsegtem, és olyan új szemléletmódra tettem szert, amellyel megelőztem minden embert. ${ }^{137}$

Nietzsche tehát maga is tisztában van felfedezése súlyával; de igyekszik megőrizni higgadtságát, és tovább dolgozik $A$ vidám tudományon, hogy előkészítse a talajt legnagyobb gondolata számára. A moralitás alapjainak felszámolása után Nietzsche szerint kérdésessé vált, hogy a tudomány képes lehet-e új célt ,adni” az emberi cselekvésnek, ugyanis pontosan a teleologikus gondolkodás az, aminek végérvényesen leáldozott a metafizikai-erkölcsi világrend kritikájával. A vidám tudomány központi gondolata a tudás „bekebelezésének”

\footnotetext{
${ }^{133}$ Vagy „feladatnak”, lásd fentebb.

${ }^{134} \mathrm{H} 453 . \S$

${ }^{135} \mathrm{H} 455 . \S$

136 „Itt ültem, s vártam, vártam - semmire, / túl jón s rosszon, a táj fényeire / s árnyaira, merő játék, merő / tó és dél, merő céltalan idő. / S az Egy Kettővé lett egy perc alatt - / s Zarathustra előttem elhaladt." Friedrich Nietzsche: „Sils Maria.” Ford. Lator László. In: Friedrich Nietzsche: Versei. Ford. Csorba Győző et al., vál.: Hajnal Gábor. Európa, Bp., 1989, 28. o.

${ }^{137}$ Friedrich Nietzsche: Válogatott levelei. 1861. január-1889. január. Ford. Romhányi Török Gábor. Holnap, Bp., 2008. 107. o.
} 
[einverleiben], „ösztönössé tételének” szükségessége. ${ }^{138}$ Fel kell ismernünk, hogy az ösztön minden megismerés alapja, egy ponton azonban a megismerés ellenségévé válik: mikor az ember már kizárólag a megismerésnek él, az lesz legfőbb szenvedélye, alapösztöne. Vajon egészséges egyáltalán az ilyen élet? A megismerés eredetileg birtoklási vágy, a világ magunkévá-tételére irányuló erő, és ez az, ami alapvető ösztönünk. Minden ezzel ellentétes irányú mozgás gyengíti az életet; a morál pedig éppen az ön-megtagadás müvészete. Az erős embernek, a „szabad szellemnek” van ereje és bátorsága nemet mondani a bevett értékekre, mert tudja, hogy csak ezáltal válhat önmagává. ${ }^{139}$ Ismét előtérbe kerül tehát az emlékezésfelejtés probléma. Az „igazság akarása” egyrészt természetes ösztönünk, ez azonban egy szinten túl már az életerő útjában áll. Ha az igazság metaforikus és plurális, akkor én magam, az „önmagam” is az; ezért szenvedünk és emiatt sírunk, holott, mondja Nietzsche, akár örömünket is lelhetnénk benne, $\mathrm{ki}$ is kacaghatnánk végzetünket, szükségszerü esetlegességünket affirmálva. ${ }^{140}$ Bacsó Béla az igazság akarását elsősorban az interpretáció művészeteként értelmezi, melynek révén kvázi hibernáljuk a valóságot, kiiktatva belőle a változásban lévőt mint olyat. A tragikus gondolkodásnak tudomása van az interpretáció megszüntethetetlen akarásáról, és a végletekig hajtva az igazság akarását, a „legszélsőségesebb kívül-állásban” önmaga elé, önmagával szembe állítja a világot: ez a nietzschei perspektivizmus lényege. ${ }^{141}$ Nagyon fontos azonban annak felismerése, hogy az „,igazság akarása” maga is betegséggé válhat; ez jelzi ugyanis a szigorú szellemi diéta végét, a „második átváltozás" ${ }^{142}$ megtörténtét, és a dionüszoszi filozófia kezdetét.

\footnotetext{
${ }^{138}$ Vö. KSA 9. 495 ,Was früher am stärksten reizte, wirkt jetzt ganz anders, es wird nur noch als Spiel angesehn und gelten gelassen (die Leidenschaften und Arbeiten) als ein Leben im Umwahren principiell verworfen, als Form und Reiz aber ästhetisch genossen und gepflegt, wir stellen uns wie die Kinder zu dem, was früher den Ernst des Daseins ausmachte. Unser Streben des Ernstes ist aber alles als werdend zu verstehen, uns als Individuum $\mathrm{zu}$ verleugnen, möglichst aus vielen Augen in die Welt sehen, leben in Trieben und Beschäftigungen, um damit sich Augen zu machen, zeitweilig sich dem Leben überlassen, um hernach zeitweilig über ihm mit dem Auge zu ruhen: die Triebe unterhalten als Fundament alles Erkennens, aber wissen, wo sie Gegner des Erkennens werden: in summa abwarten, wie weit das Wissen und die Wahrheit sich einverleiben können - und in wiefern eine Umwandlung des Menschen eintritt, wenn er endlich nur noch lebt, um zu erkennen.” (Nietzsche ezeket a sorokat 1881. augusztusának első napjaiban, „6000 lábbal a tengerszint, és még sokkal magasabban minden emberi dolog felett” vetette papírra.), illetve VT 11. és 110 . $\S$

139. „Élni - azt jelenti: szakadatlanul eltaszítani magunktól mindazt, ami haldoklik, élni - azt jelenti: kegyetlennek és kérlelhetetlennek lenni minden ellen, ami csak gyönge és régi van bennünk és nem csak bennünk. Élni - tehát ezt jelenti: nem szánni a haldoklót, a nyomorultat, az elaggottat? Szakadatlanul gyilkosnak lenni? - és az öreg Mózes mégis így szólt: »Ne ölj!«.” VT 26. §, lásd továbbá 28. § (kiemelés tőlem, L. E.)

${ }^{140}$ Vö. Pierre Klossowski: „Nietzsche, a sokistenhit és a paródia.” Ford. Szántó F. István. In: Athenaeum, 1992. I/3. A francia Nietzsche-recepció. 84-95. o. Klossowski tehát éppen az ellentétét állítja annak, amit Heidegger mond: az örök visszatérés nem csak, hogy nem alárendelt a hatalom akarásának, hanem ellenkezöleg: az örök visszatérés „az akaratot az akart pillanat akarásáig viszi el (...) a hatalom akarása csupán a létezés attribútuma, amely magát nem akarhatja másként, mint ami." (U. ott 95. o.)

${ }^{141}$ Vö. Bacsó Béla: , Mert nem mi tudunk...” Filozófiai és müvészetelméleti írások. Kijárat, Bp., 1999, 49-62. o.

${ }^{142}$ Vö. Z I:455-522 „A három átváltozásról”
} 
A megismerés mindig kegyetlen, tragikus és veszélyes; az ő ,igazságérzéke”: a kísérletezés „merészségének” elveszítése, cserébe gyermek ártatlan, könnyed vidámságáért. ${ }^{143}$ A megismerés nem más, mint a bizonyosság és az öröklét kockára tétele - az élet szolgálatában. A müvészetre pedig minden eddiginél nagyobb szükség van, mert szükség van a látszatra - a „fényes nappal alvajárói” ${ }^{144}$ valóságként élik meg, és ezáltalvalósággá teszikaz álmot. Nietzsche az igazsághoz való viszonyunkat a nők iránti vágyakozásunkhoz hasonlítja; ezen keresztül ,a távolba és a csöndbe menekítjük a boldogságunkat”; a nő és az igazság ereje tehát egyaránt actio in distans: a távolság ereje. ${ }^{145}$ Mikor Nietzsche a hérakleitoszi hübrisz értelmezésekor az ellentétekben való gondolkodás ellen érvel, azt mondja, a „contuitív” szemlélet motorja az állandóan újraéledő játékösztön, amely voltaképpen a teremtés ösztöne és egyben minden keletkezés legfőbb elve. ${ }^{146}$ Aki tehát a folyamat egységében látja a világot, az határtalan különbözést lát ott, ahol a metafizika embere ellentéteket feltételezett. Most megismétli: „egy intellektus, aki képes volna kontinuumként látni az okot és okozatot [...], elvetné az ok és az okozat fogalmát, valamint tagadna minden feltételhez kötöttséget."147 Mikor tehát kimondja Isten halálát, Nietzsche a feltétlen ember megszületését ünnepli, de tisztában van vele, hogy eltart még egy ideig, amíg „Isten árnyékától is megszabadulunk”148 _ hiszen csak kevesek képesek elviselni annak következményeit, hogy „,e földet elszakítottuk napjától”. ${ }^{149} \mathrm{Az}$, aki lemond a bizonyosságról, mindent alárendel a véletlennek, ${ }^{150}$ erre pedig csak azok képesek, akik megértették Hérakleitoszt, és „látják a szükségszerüségben rejlő játékot". ${ }^{151}$

Az amor fati gyönyörü gondolatával kezdődő negyedik könyv hangulata szinte eksztatikus; telis-teli a fény, a repülés, az éteri metaforáival. Ugyanakkor nagy hangsúlyt kap a madártávlat distancia-teremtő tulajdonsága; nekünk ugyanis magasabbra kell emelkednünk még a művészeknél is: ők csak művészetükben távolodnak el a valóságtól, nekünk viszont egész életünket kell kockára tennünk. Olyan magasságba kell felszállnunk, ahonnan már

\footnotetext{
${ }^{143}$ Vö. VT 46., 51., 53., 54. §

${ }^{144}$ VT 59. §

${ }^{145} \mathrm{Ld}$. VT $60 . \S$

${ }^{146}$ FGTK 90-91. o.

${ }^{147}$ VT 112. § (kiemelés tölem, L. E.)

${ }^{148}$ Ld. VT 108. § Nietzsche Platón barlang-hasonlatának felidézésével szemlélteti az idealizmus folyamatosan fenyegető lehetőségét.

${ }^{149}$ VT 125. § Először szólal meg az őrült; a paprikajancsi, akinek nem kell elhinnünk - az igazat.

${ }^{150}$ Ismét Klossowski: az egy Istenben, az Igazságban és az identitásban való hit az igazság és az öntudat eredendően plurális természetének egyenes következménye. Isten halálával mindez eltünik, de az imádat [erosz] ösztöne megmarad, és az (ön)teremtés ösztönével párosulva a hatalomakarásban fejezi ki magát. A dionüszoszi szétszóródás a „sokistenhit” szimbóluma, a szétszaggatást kísérő kacagás pedig az Isten /Igazság halálából újjászületö isteneké. (Vö. Klossowski [1992] 99-103. o.)

${ }_{151}^{15}$ FGTK 97. o.
} 
semmit nem látunk saját magunkból - csak így lehetünk saját életünk költői. ${ }^{152}$ Ahhoz azonban, hogy önmagunkká váljunk, tudnunk kellene, kik is vagyunk, ehhez pedig akkor juthatunk a legközelebb, ha ún. „morális” cselekedeteink motivációit vizsgáljuk. Ezekkel kapcsolatban három autoriter tényezőre szeretünk hivatkozni: lelkiismeretünkre, a kötelességre, és a morális törvények egyetemességére. Nietzsche ezekkel az „intellektuális lelkiismeretet”, az önzést és a jóízlést szegezi szembe: túl-világi értékek helyett induljunk ki magunkból; abból, ami van - Éljen a fizika! - mondja. Semmilyen tekintetben nem szabad szenvednünk az élettől; ehelyett igent kell mondanunk a szenvedésre, mint az élet természetes velejárójára. Sőt, a szenvedés éppen, hogy a legfontosabb posztulátuma az életnek: minden fájdalom mulandóságunkra emlékeztet. De végességünkben osztozik minden létező, hiszen keletkezés és elmúlás minden pillanatban, minden ,itt és most”-ban keresztezik egymást. Az „,itt és most” egyszerre jelenti a létezés mulandóságát és örökkévalóságát; így lesz örök a keletkezés és ugyanaz a lét - mindörökre. Az emberi létezés egyedüli formulája csak ez lehet: „,amor fati”; eljött az ideje Zarathustra alászállásának, hogy emberré válva az örök visszatérés rettentő gondolatát tanítsa.

$A$ vidám tudomány legfontosabb, 341. aforizmájában Nietzsche először érzi meg a „rettenetes és korlátlan Igen és Ámen” jelentőségét, a démon által feltett kérdés pedig a minden kérdezést megnyitó kérdés; az igent/nemet mondás erre a kérdésre egy minden igent/nemet megelőző igenen és ámenen nyugszik. Az örök visszatérésre mondott igen tehát paradox módon egyszersmind a mulandó létezés egyszeri, megismételhetetlen ismétlődésére mondott igen is; ez az igen az utána jövő összes döntés egyszeriségén és általánosságán túl van. Az örök visszatérés kettős igenje egyrészt az igen mondása, másrészt pedig az igentmondás abszurditásán való nevetés: a visszatérésre mondott igenben az értékelés az egyedihez tér vissza, de az örökkévalóvá válásban a visszatérés az általánosítás bünét ismétli. Ez a büntetés pillanata, amikor a tragédia paródiává, a „legnagyobb teher” pedig a legnagyobb örömmé változik. Howard Caygill a kanti „törvényhozó filozófust” tekinti Nietzsche „szabad szelleme” előképének. Ez a fajta „törvényhozás” ugyanis egyfajta határoltságot, tehát büntetést is von maga után, így nem tekinthető megalapozásnak. Hasonlóan a „szabad szellem” korábban tárgyalt, „első” döntéséhez, a törvényadásnak ez az első ,,adása” megelőzi az összes későbbi törvényadást, mint azok lehetőségfeltétele. A törvényadás egyszersmind feltalálás is: túl van a meglévő határok elfogadásán, a lehetőség-adásban azonban határtalanná válik, magának az adás lehetőségének korlátlanságává, így tehát semmiképp sem

${ }^{152}$ VT. 299. § 
megalapozás. Caygill véleménye szerint Nietzsche valóban betetőzte a kanti munkát azzal, hogy rehabilitálta az ítélet és a feltalálás a modernitás filozófiájában elfeledetté vált, eredeti összetartozását. Az értékek átértékelésének programja voltaképpen az ítélet, az affirmáció felszabadításának programja, mely így, immár az igen/nem súlya alól mentesen, valóban teremtővé válik. ${ }^{153}$

A tézisünkben hangsúlyozott Kant-Nietzsche hatástörténeti összefüggés immár pozitív értelemben is körvonalazható. Nietzsche maga is kifejezetten törekedett a „kanti-kopernikuszi fordulat" radikalizálására; ebben az értelemben tehát szinte magától értetődik, hogy Kantkritikája nem merülhet ki a puszta polémiában. Ennek remek példája a kanti, illetve nietzschei morálfilozófia közti különbségek és hasonlóságok által felvetett probléma, amely, úgy véljük, a nietzschei metafizika-kritika neokantiánus ihletettségét állító tézisünket is alátámaszthatja. Ullmann Tamás az „örök visszatérés imperatívuszát” vizsgálva azt a korántsem érdektelen kérdést teszi fel, hogy vajon a perspektívák nietzschei sokfélesége megenged-e mégis valamilyen általánosságot, mely utóbbi a normativitás, a moralitás általában vett előfeltétele. Ullmann gondolatmenete a következő: Nietzschének a kanti morálfilozófiát illető kritikája alapjában véve a magánvaló dolog koncepciója, a „két világ” kanti elmélete ellen irányul; ezzel szemben az értékek átértékelésének, az új értékek tételezésének követelménye az igazság perspektivikus fogalmát veszi alapul. Ugyanezen okból azonban igenis beszélhetünk, sőt beszélnünk kell morálfilozófiáról Nietzsche esetében, ugyanis az értékek létezésének tagadása szintén az „érték” abszolutisztikus fogalmát előfeltételezné, míg a nietzschei kritika éppen ezt, tehát az értékek értékét szándékozik kétségbe vonni. Az egyedüli általánosság, amely ezen új értékek alapjául szolgálhat, maga az örök visszatérés, ami, mutat rá Ullmann, úgy képes kifejezni az élet eleven, fiziológiai jellegét, hogy eközben mentes a physis fogalmának hagyományos, metafizikus, illetve teleologikus konnotációitól. Az örök visszatérés nem tesz lehetővé semmiféle, önmagán kívüli normativitást. Ullmann tehát a következőkben látja kifejeződni a kanti és a nietzschei morálfilozófia hasonlóságát: az imperatívuszok (a kanti kategorikus imperatívusz, illetve az önálló értékek tételezésének nietzschei parancsa) mindkét esetben formálisak, gyakorlati alkalmazásuk pedig épp ezért problematikus. A „rossz” mindkét filozófusnál immanens, tehát „[túlságosan is] emberi”, kivédésének módja tehát szintén nem alapulhat valamilyen külső ok fennállásán. Míg Kantnál a kategorikus imperatívusz feltétlenségét a szabadság ténye, addig Nietzschénél az „,intellektuális becsület” [Redlichkeit] hivatott garantálni. Kant „feltételes” imperatívuszának

\footnotetext{
${ }^{153}$ Vö. Caygill (1991) pp. 234-236.
} 
elméleti (okosság), illetve gyakorlati (jártasság) aspektusa együtt sem képes felvenni a versenyt az abszolútum erejével; Nietzsche pedig magát az abszolútumot, az általános érvény lehetőségfeltételét tagadja. ${ }^{154}$ „Érdekes módon azonban a formális imperatívusztól a valóságos cselekvéshez átvezető közbülső lépcsőfok egyiküknél sem valamilyen gyakorlati ítélőerö. A legföbb és legfontosabb támasz nem a mérlegelö okosság antik erénye, hanem a hamisság leleplezésének képessége." ${ }^{155}$ Caygill és Ullmann eredményeinek fényében felébred bennünk a gyanú, hogy a kutatás a mai napig adós a nietzschei ismeretelmélet, illetve a kései, morálkritikai művek közti lényegi összefüggés kimerítő vizsgálatával.

Azonban térjünk vissza A vidám tudományhoz. Még a 341. aforizmánál is „súlyosabb” az a töredék, melyet Nietzsche 1881. augusztus elején, „6000 lábbal a tengerszint felett, és még magasabban minden emberi dolog felett” jegyez le. Így ír:

Szándékunk komolysága, hogy mindent keletkezőként értsünk, hogy tagadjuk önmagunkat mint individuumokat, hogy annyi tekinteten keresztül lássuk a világot, amennyin csak lehetséges, hogy ezen perspektívák megteremtése céljából az ösztönöknek és a cselekedeteknek éljünk, hogy átmenetileg lemondjunk az életről, hogy aztán átmenetileg rajta nyugtathassuk pillantásunkat: fenntartani az ösztönöket mint minden tudás alapját, de tudni, mely ponton válnak a tudás ellenségeivé, összességében: kivárni, és megfigyelni, milyen mértékben kebelezhető be a tudás és az igazság - és hogy milyen mértékben alakulát az ember, mikor már csak a megismerés kedvéért él. Ez a következménye a megismerés szenvedélyének: nincs mód ennek fenntartására, kivéve, ha a megismerés forrásait és hajtóerőit, a tévedéseket és a szenvedélyeket is megőrizzük; a kettő konfliktusából ered a megismerést fenntartó erő. [...] De most következik a legsúlyosabb tudás, mely az élet legkegyetlenebb újragondolására szólít fel: az élvezet abszolút többletének láthatóvá kell válnia, másképpen meg kell semmisítenünk magunkat az emberiségre való tekintettel, a pusztító emberiség értelmében. Éppen így: mérlegre kell tennünk a múltat - a sajátunkat és az egész emberiségét - és meg kell haladnunk - nem! az emberi történelemnek ez a darabja az örökkévalóságig kell, és fog is ismétlődni; mindezt figyelmen kívül hagyhatjuk, nincs rá semmilyen befolyásunk: még akkor sem, ha felkelti felebaráti érzéseinket és elfogulttá tesz minket az élettel szemben általában véve. Ha nem akarjuk, hogy eluralkodjék rajtunk, részvétünk nem lehet túl erős. Az azonosságot mélyen el kell temetnünk önmagunkban, akárcsak a szemlélődésben lelt élvezetet. Még az eljövendő emberiség szenvedése sem érinthet meg minket. A kérdés az: vajon még mindig akarunk-e élni: és hogyan! ${ }^{156}$

\footnotetext{
${ }^{154}$ Vö. Ullmann Tamás: „Az örök visszatérés imperatívusza.” In: Holmi, 2004/10. 1275-1286. o.

${ }^{155}$ U. ott 1285. o. (kiemelés tölem, L. E.)

${ }^{156}$ KSA 9.494 sk. „Unser Streben des Ernstes ist aber alles als werdend zu verstehen, uns als Individuum zu verleugnen, möglichst aus vielen Augen in die Welt sehen, leben in Trieben und Beschäftigungen, um damit sich Augen zu machen, zeitweilig sich dem Leben überlassen, um hernach zeitweilig über ihm mit dem Auge zu ruhen: die Triebe unterhalten als Fundament alles Erkennens, aber wissen, wo sie Gegner des Erkennens werden: in summa abwarten, wie weit das Wissen und die Wahrheit sich einverleiben können - und in wiefern eine
} 
Nietzsche hozzáteszi: a legnehezebb gondolat annak felismerése, hogy vélekedéseink határozzák meg cselekedeteinket; hatásuk még erősebb, mint a körülményeké, hiszen azok már eleve kondicionáltak ezen előzetes vélemények által. A legnehezebb, minden más gondolatot megelőző gondolat tehát magáról a tudás természetéről szól: „akarod-e mindezt még egyszer és számtalanszor újra?” A másik fontos kérdés, melyet az ugyanannak örök visszatérése kapcsán fel kell tennünk, hogy mit is jelent pontosan a visszatérés. Nietzsche már ekkor leszögezi: a visszatérés semmiképp sem az azonosság ismétlődését, hanem az élet elevenségének megőrzését jelenti. ${ }^{157}$

Az örök visszatérés gondolatának bejelentése kétségtelenül a „szabad szellemtrilógia”, és egyszersmind a gondolkodói pálya csúcsát jelenti Nietzsche számára; euforikus hangulatát a negyedik könyv aforizmáinak költőisége jelzi. Az ötödik könyv csak 1886-ban születik meg, művei újrakiadása idején, a „trilógia” két előző kötetéhez írott kései Előszókkal együtt. Nietzsche az eljövendő emberhez, az Übermenschhez szól, az ő eljövetelét várja társaival, a többi „szabad szellemmel” együtt. A ,posztumusz lét” tehát azt jelenti: előkészületként, átmenetként szolgálni a jövő számára, amelyet, bár tudomásunk van róla, sohasem élhetünk meg, ugyanis csak a mi halálunk után köszönthet be. A „,szabad szellem” átmeneti lény, a szellem utolsó átváltozásának előkészítője, aki ugyanakkor már magában foglalja ezt az átváltozást az önmagától való folyamatos el-különböződésben rejlő lehetőségként. A jövő pesszimizmusa az önmagát önfeledt táncban és nevetésben eltékozló Dionüszosz pesszimizmusa.

\footnotetext{
Umwandlung des Menschen eintritt, wenn er endlich nur noch lebt, um zu erkennen. — Dies ist Consequenz von der Leidenschaft der Erkenntniß: es giebt für ihre Existenz kein Mittel, als die Quellen und Mächte der Erkenntniß, die Irrthümer und Leidenschaften auch zu erhalten, aus deren Kampfe nimmt sie ihre erhaltende Kraft. (...) Nun kommt aber die schwerste Erkenntniß und macht alle Arten Lebens furchtbar bedenkenreich: ein absoluter Überschuß von Lust muß nachzuweisen sein, sonst ist die Vernichtung der Menschheit zu wählen. Schon dies: wir haben die Vergangenheit, unsere und die aller Menschheit, auf die Wage zu setzen und auch zu überwiegen - nein! dieses Stück Menschheitsgeschichte wird und muß sich ewig wiederholen, das dürfen wir aus der Rechnung lassen, darauf haben wir keinen Einfluß: ob es gleich unser Mitgefühl beschwert und gegen das Leben überhaupt einnimmt. Um davon nicht umgeworfen zu werden, darf unser Mitleid nicht groß sein. Die Gleichgültigkeit muß tief in uns gewirkt haben und der Genuß im Anschauen auch. Auch das Elend der zukünftigen Menschheit soll uns nichts angehn. Aber ob wir noch leben wollen, ist die Frage: und wie!"

157 Vö. pl. KSA 9.499 „Wir können uns das Werden nicht anders denken als den Übergang aus einem beharrenden »todten « Zustand in einen anderen beharrenden »todten « Zustand. Ach, wir nennen das »Todte« das Bewegungslose! Als ob es etwas Bewegungsloses gäbe! Das Lebende ist kein Gegensatz des Todten, sondern in Spezialfall."
} 


\section{Exkurzus: Sematizmus-kritika és neokantianizmus: Nietzsche és Afrikan Spir}

Afrikan Aleksandrovic Spir orosz-német értelmiségi családban született a mai Ukrajna területén; majd, miután a családi vagyon egyetlen megmaradt örököseként felszabadította szolgáit és pénzzé tette birtokait, Lipcsébe utazott, ahol Nietzschével egy időben volt hallgató, ám feltételezhetően nem ismerték egymást. ${ }^{158}$ Nietzsche 1873 áprilisában, Boscovich atomelméletével egy időben olvasta Spir Denken und Wirklichkeit. Versuch einer Erneuerung der kritischen Philosophie c. művét, ${ }^{159}$ és a ,szabad szellemeknek szóló könyvben már, ugyan név nélkül, de Spirt idézi:

Ha egyszer megírják a gondolkodás keletkezéstörténetét, akkor majd új fényben áll elöttünk egy kiváló logikus következő mondata is: »A megismerő szubjektum eredendő, általános törvénye abban a belső szükségszerüségben áll, hogy megismerjen minden tárgyat önmagában, a saját lényegiségében, önmagával azonos, önmagában létező állandó és megváltoztathatatlan szubsztanciaként.« Még ez a törvény is, amelyet itt »eredendőnek « neveznek, az időben jött létre. Egyszer még azt is kimutatják, hogy ez a hajlam az alacsonyabb rendủ organizmusokban keletkezett és roppant lassan alakult ki, ahogy az ilyen organizmusok ostoba vakondszemei is mindig csak ugyanazt látják kezdetben; ahogy aztán később érezhetők lesznek a kellemes és kellemetlen érzetek hullámzó váltakozásai, úgy lassanként különféle szubsztanciákat lehet megkülönböztetni, amelyeket egyetlen attribútum jellemez az említett organizmushoz való viszonyukban. ${ }^{160}$

Spir filozófiájának Nietzsche Kant-kritikájában, és tágabb kontextusban Nietzsche metafizikakritikájában játszott szerepének kitünő értelmezését nyújtja Michael Steven Green Nietzsche and the transcendental tradition címủ munkája. ${ }^{161}$ A ,„posztmodern” (tehát antinaturalista) értelmezések, állítja Green, Heidegger interpretációját is ide sorolva, a nietzschei filozófia metafizikus jellegét emelik ki, azt állítván, hogy a hatalom akarása és az örök visszatérés gondolata a világ intelligibilis karakterét tételező, tehát alapvetően metafizikus világmagyarázat részét képezik. Az ilyen interpretációk azonban nem veszik figyelembe Nietzschének a naturalizmus és az empiricizmus iránti eredeti és töretlen hajlandóságát.

\footnotetext{
${ }^{158}$ Vö. Theodor Lessing: African Spir's Erkenntnislehre. Münchow, Giessen, 1900, s. 9-18; illetve Schlechta Anders (1962) s. 119-120, 159.

${ }_{159}$ Ld. Nietzsche's Library. Comp. Rainer H. Janshe. Online: http://www.nietzschecircle.com/Pdf/NIETZSCHE_S_LIBRARY.pdf

${ }^{160}$ EE 18. $\$$

${ }^{161}$ Michael Steven Green: Nietzsche and the Transcendental Tradition. Illinois UP, Urbana-Chicago, 2002. (Green írásának a nietzschei gondolkodás analitikus filozófiára gyakorolt hatását tárgyaló részeit e helyt nem tartjuk szükségesnek tárgyalni.)
} 
Analitikus filozófusként Greent Nietzsche filozófiájának pozitív aspektusai érdeklik; hiszen, mint mondja, Nietzsche igen konkrét (méghozzá naturalista) kijelentéseket tesz a világról, az emberről, és kettejük viszonyáról. Nietzsche célja az, hogy a naturalizmust úgymond megtisztítsa a benne rejlő nem-naturalista elemektől, nem pedig az, hogy a naturalizmust egyszerűen esztétikával váltsa ki. Ehhez pedig egyrészt olyan ismeretelméletre van szükség, mely nem vezet az én antinaturalista koncepciójához, másrészt pedig egy olyan természetelméletre, mely igazságot szolgáltat az érzet-adatoknak. Sajnos azonban ez a két törekvés ellentmond egymásnak, de épp az ezen ellentmondásból származó feszültség Nietzsche ismeretelméletének meghatározó eleme, mely abból ered, hogy Nietzsche, Kanttal polemizálva, naturalizálja az összes lehetséges ítéletet, sőt, az ítéletet mint olyat, ezzel azonban az általában vett igazság lehetőségét vonja kétségbe - így saját naturalizmusának igazságáét is. Ezt a paradox pozíciót, mellyel a „posztmodern” értelmezések nem tudtak elszámolni, Green egyfajta „elgondolhatatlan formában elgondolt”162 naturalizmusnak nevezi, amennyiben, éppen a folyamatos létrejövés központi gondolatával Nietzsche végső soron erőszakot tesz mindenfajta lehetséges naturalizmuson.

Green úgy véli, Nietzsche igazsággal kapcsolatos megfontolásának eredete az Afrikan Spir neokantiánus sematizmus-kritikája által közvetített kanti transzcendentálfilozófia. ${ }^{163}$ Nietzsche a helyes ítéletről szóló kanti definíciót támadja, mikor megismerésünk megszokott müködését hibásnak, a naturalizmus gondolatával összeférhetetlennek tartja. Kant szerint ugyanis csak a szükségszerű és atemporális elmebeli asszociációk alapján tehetünk kijelentéseket a világról, legyenek azok igazak vagy hamisak; az asszociáció törvényei azonban csak feltételes érvénnyel bírnak, hiszen az asszociáció a posteriori, vagyis tapasztalaton alapuló ítélet. Nietzsche ismeretelméletében az érvek két típusát fedezhetjük fel, mondja Green. Az elsőbe azok a főleg korai írásokat jellemző argumentumokat sorolja, melyek szerint ítéleteink érzéki eredete felelős a tévedésért, a másikba pedig a későbbi írásokban rendre felbukkanó érvmenetekat, melyek a normatív igazságfogalom, a metafizikus igazságelméletek sematizmusának kritikájára fókuszálnak. Az érvek ezen második típusának értelmezésekor azonban megkerülhetetlen Nietzsche transzcendentálfilozófiához való viszonyának figyelmes vizsgálata, melynek kapcsán Afrikan Spir „,közvetítői” szerepe kiemelt jelentőséggel bír. Green szerint Nietzsche logikája a következő: mivel a világ folyamatos változás és létrejövés, igazat mondok, amikor ezt állítom róla; ebből következik Nietzsche

\footnotetext{
${ }^{162}$ Vö. Green (2002) p. 7.

${ }^{163}$ Vö. Green (2002) pp. 3-8.
} 
teljes mértékben „implauzibilis”, „kvázi-tudományos” világértelmezése, mely azonban a fentieket alapul véve le sem tagadhatná a kanti alapokat.Bármilyen gyorsan változzék is a világ, a pillanatnyi állapotok leírása legalább lehetséges kell, hogy legyen. Hiszen mikor Nietzsche azt állítja, a világ nem olyan, amilyennek hisszük, azt is állítja, hogy ő viszont tudja, milyen valójában. ${ }^{164}$

Green első lépésben Nietzsche gondolkodásának neokantiánus inspirációját vizsgálja. 1. Kant a „kategóriának” a fogalom-tárgy viszony általános ítéleti formájaként értett fogalmának, szorosabban a szubsztancia alapkategóriájának felvételével alapozza meg a szubjektum-predikátum viszonyként értett kategoriális ismeret lehetőségét. Felfogásában a naturalizmus irreleváns az ítéletek igazságának vagy hamisságának (azaz objektív érvényességének) tekintetében, mert az objektummal kapcsolatos ítéletet az észlelésre, vagyis a szubjektumban bekövetkező tökéletesen esetleges változásokra alapozza. A naturalista ismeretelmélet maximum az elme egyik észlelettől a másikig tartó mozgásának leírására lehet alkalmas; a megismerés voltaképpeni folyamatának értelmezésére, melynek alapmotívuma az elmének a tárgyra való vonatkozása, azonban semmiképp. 2. Az appercepció, tehát a tudatos észlelés kanti elméletében központi szerepet játszik a gondolat szükségszerüsége és atemporalitása, illetve a tapasztalat sokfélesége és időbelisége közti szakadékot áthidalni hivatott transzcendentális sematizmus, melynek kategóriái révén a gondolat képes lesz egységbe foglalni az érzéki sokféleséget. A kanti „kopernikuszi fordulat” lényege a „transzcendentális anti-realizmus”: azzal, hogy megkülönbözteti a tárgy számunkra megjelenő képét (reprezentációját) a magánvaló dologtól, mely elménktől függetlenül létezik, úgy őrzi meg az ítéletek szubjektív vonatkozását, hogy mindeközben azok objektív érvényessége sem sérül. 3. Az ítéletek objektivitását Kant a gondolkodás abszolút formális karakterére (kategoriális jellegére) alapozza, ez a transzcendentális sematizmus lényege. A sematizmus pedig az a pont, mondja Green, ahol Nietzsche ismeretelmélete egyértelműen kapcsolódik a transzcendentálfilozófiához, méghozzá Afrikan Spir Kant-kritikáján keresztül. Spir szerint az appercepció egysége kanti gondolatának két fő jellegzetessége annak időtlen, illetve egységes jellege, azonban mindez kevés ahhoz, hogy áthidalja a gondolati egység és az empirikus sokaság viszonyának problémáját. Spir Gondolkodás és valóság c. írásában azt állítja, a kanti sematizmus tévedés, mert az empirikus ítélet mindig erőszakot tesz a valóságon. Az empirikus tárgyak és ideáink közti eltérésekböl ekkor ugyanis arra következtetünk, hogy a

\footnotetext{
${ }^{164}$ Vö. Green (2002) pp. 517-35.
} 
világról alkotott képünk téves - ahelyett, hogy összevetnénk ezt a képet a valósággal. ${ }^{165}$ Spir arra következtet, hogy meg kell különböztetnünk egymástól a létezőket és a létrejövést; melyek közül, a parmenidészi Egy nyomán, az abszolút önazonos létezést tekinti elsőrendűnek, mely kisajátítja az elgondolhatóság lehetőségét, de elveszíti a változásét. ${ }^{166}$ Fontos azonban megjegyeznünk, hogy ezt az egységet Spir nem analitikus módon, azaz változatlan önazonosságként [Sichselbstgleichen], hanem valódi-reális, szintetikus egységként állítja. $^{167}$ 5. Spir Kant-kritikájának középpontjában a feloldhatatlan, „fundamentális antinómiának" "168 a Denken und Wirklichkeit első kötetének végén bevezetett gondolata áll,

${ }^{165}$ Vö. Afrikan Spir: Denken und Wirklichkeit: Versuch einer Erneuerung der kritischen Philosophie. J. G. Findel, Leipzig, 1873. I:264. „Nun ist es aber erstens klar, dass ich von einer Succession als solchen nichts wissen kann, wenn ich die aufeinanderfolgenden Glieder derselben nicht zugleich in meinem Bewusstsein habe. Die Vorstellung einer Succession ist also selbst gar nicht successiv, folglich auch von der Succession unserer Vorstellungen durchaus verschieden. Zweitens implicirt die Annahme Kant's so offenbare Absurditäten, dass es Einen Wunder nimmt, wie er sie unbeachtet lassen konnte.” (Ld.. KSA 1.857)

${ }^{166}$ Vö. Spir (1873) I:261-264.

${ }^{167}$ Vö. Spir (1873) 194-195. ,Zuerst will ich nun bemerken, dass die Formel »Ein Jedes ist, was es ist« nicht die nöthige Präcision hat. Denn es geschieht ja oft, dass uns etwas nicht das zu sein scheint, was es an sich, in Wahrheit ist. Man soll folglich den Satz so ausdrücken: An sich, seinem eigenen oder wahren Wesen nach ist jedes Ding, jedes Object, jedes Reale sich selbst gleich oder mit sich identisch. Es fragt sich nun: Ist etwas über die Natur der Gegenstände, also überhaupt der Wirklichkeit, durch diesen Satz ausgesagt oder nicht? Diese Frage ist gar nicht schwer zu beantworten. Denn es kommt bloss darauf an, ob eine Wirklichkeit imaginirt werden kann, welche mit dem Satze der Identität nicht übereinstimmte, in welcher derselbe keine Gültigkeit gehabt hätte, oder nicht. Kann eine solche Wirklichkeit gar nicht einmal hypothetisch gedacht werden, dann ist der Begriff des Wirklichen oder Realen gar nicht unterschieden von dem Begriffe des Mitsichidentischen oder des Sichselbstgleichen, und der Satz der Identität ist also ein bloss tautologischer oder identischer (nach Kant's Ausdrucksweise: analytischer) Satz. Denn Subject und Prädicat in demselben bedeuten dann genau dasselbe. Im entgegengesetzten Falle aber nicht. Nun ist unzweifelhaft das letztere der Fall. Wir können uns hypothetisch denken, dass alles Wirkliche in einem unaufhörlichen Fluss oder Wechsel begriffen sei, ohne einen Augenblick stille zu stehen und seine Beschaffenheit festzuhalten, oder auch dass jedes Einzelne zugleich auch alles Andere sei. In einer so gearteten Wirklichkeit würde der Satz der Identität offenbar keine Gültigkeit haben. Der Begriff des Realen oder Wirklichen einerseits und derjenige des Sichselbstgleichen oder Mitsichidentischen andererseits sind also nicht ein und derselbe, sondern zwei verschiedene Begriffe. Folglich ist der Satz der Identität, welcher eine Verbindung dieser zwei verschiedenen Begriffe ausdrückt, nicht ein identischer, sondern ein synthetischer Satz. Als solcher kann er zur Prämisse eines Syllogismus und somit zum Principe der Wissenschaft dienen.” (kiemelések tölem, L. E.)

${ }^{168}$ Spir (1873) I:452-53. „Die Antinomie, welche in der bedingten Natur des Geschehens oder der Veränderung liegt, kommt am klarsten darin zu Tage, dass die Reihe der Ursachen des Geschehens, ins Unendliche rückwärts geht. Kant hat die Behauptung der Anfangslosigkeit der Begründung im Geschehen als die Antithese aufgestellt; unter der These dagegen die Forderung einer definitiven Begründung, einer ersten Ursache des Geschehens verstanden und beide durch verschiedene Gründe zu unterstützen gesucht. Allein beides, These und Antithese, ist hier ganz unzertrennlich in einander involvirt. Denn die Forderung einer Begründung überhaupt ist nothwendig zugleich die Forderung einer definitiven Begründung. Die Antinomie besteht gerade darin, dass eben derselbe Satz der Gausalität, welcher zu jeder Veränderung eine Ursache oder Bedingung fordert, mithin jede Veränderung als begründet ansehen lässt, zugleich alle Möglichkeit einer ersten Ursache oder einer definitiven Begründung der Veränderungen ausschliesst. Alles, was geschieht, hat im Einzelnen seine Ursache, aber das Geschehen überhaupt als solches kann keine Ursache haben. Beides folgt aus dem Gausalitätsgesetze oder vielmehr aus der Grundlage desselben, d. h. dem Umstände, dass das Geschehen dem urpsrünglichen Wesen des Wirklichen fremd ist. Ausser dem Wechsel oder der Veränderung selber gibt es nun noch drei Elemente in der erfahrungsmässigen Wirklichkeit, welche dem wahren, ursprünglichen Wesen der Dinge, dem Realen an sich fremd sind, nämlich:

1) Die Relativität, der Zusammenhang des Verschiedenen in der Welt.

2) Die Unwahrheit, welche in der Erkenntniss des Wirklichen vorkommt.

3) Das Uebel und das daraus hervorgehende Streben, der Trieb zur Veränderung." (kiemelések tölem, L. E.) 
amely alatt Spir az emberi gondolkodás belső ellentmondását, a létezés és a keletkezés összeegyeztetésére való képtelenségét érti. A világ, mely természete szerint folyamatos keletkezés és változás, e folyamatosságban újra meg újra megsérti az ön-azonosság törvényét. Ez persze felveti az empirikus sokféleség elgondolhatóságának problémáját; hiszen ezek, mint érzékelhető és elgondolható létezők, mind a létből, mind pedig a keletkezésből részesülnek. A „fundamentális antinómia” tehát azt a problémát jelöli, melynek a korlátolt, meghatározott létezők általános fogalmakkal való leírásakor ütközünk. Ezért az értelem szintézise soha nem lesz képes megszüntetni a tapasztalati különbözőséget; az ellentmondás tehát nem az érzékelésen vagy az értelmen belül, hanem éppen e két szféra között áll fenn; a szintetikus ítélet ellentmond az önazonosság és az ellentmondás törvényének. Spir tehát fenntartja az ellentmondás törvényét, mondván: „,egy tárgyról mindössze annyit állíthatunk, hogy »A az A« és »A nem $\mathrm{B} \ll$, de soha nem mondhatjuk, hogy »A az B«. ${ }^{169}$ Ez azonban nem jelenti, hogy egy adott pillanatban a dolog ne lenne azonos önmagával; az ön-azonosság a változás minden pillanatában fennáll. A valóság tehát Spir számára folyamatos keletkezés, változás, és mint ilyen, elgondolhatatlan. Nietzsche azonban, mondja Green, éppen ezt utat választotta, azzal a különbséggel, hogy míg a sokféleség Spir által felvázolt világa megismerhetetlen, Nietzschénél a megismerés folyamata a keletkezéssel párhuzamosan halad - és ahhoz hasonlóan soha nem tekinthető befejezettnek. ${ }^{170}$

Green alapos elemzése rávilágít: Spir Kant-kritikájának egyik kulcsmomentuma kétségtelenül az időbeliség-problematika. Ha ugyanis az elmebeli folyamatok időbelisége nem reális időbeliség, akkor nincs értelme az appercepció szintetikus egységéről beszélnünk, hiszen ez esetben nem lenne semmi, amit egység alá kellene foglalni; nem létezne a képzelőerő transzcendentális szintézise és nem léteznének a priori szintetikus ítéletek sem. Mivel pedig az, amivel a transzcendentális szintézis dolgozik, valami időbeli, így maga a transzcendentális szintézis is csak temporális folyamatként képzelhető el. ${ }^{171}$ Ezen gondolat a második részben, a heideggeri ontológiai differencia fogalmának vizsgálatakor, illetve Heideggernek egyfelöl a kanti, másfelöl a nietzschei időfelfogásra vonatkozó kritikájának tárgyalásakor kiemelt jelentőségü lesz.

\footnotetext{
${ }^{169}$ Spir (1873) I:197. „Das Einzige, was man dann von einem Gegenstande würde aussagen können, wäre eben nur dieses: »A ist $\mathrm{A} \ll$ und $» \mathrm{~A}$ ist nicht $\mathrm{B} \ll$, aber niemals $» \mathrm{~A}$ ist $\mathrm{B} \ll$. Der Ausdruck $\gg \mathrm{A}$ ist $\mathrm{B} \ll$ kann zwar einen Sinn haben, welcher dem Satze der Identität nicht widerspricht, aber nie kann er etwas ausdrücken, das mit diesem Satze vollkommen übereinstimmte."

${ }^{170}$ Vö. Green (2002) pp. 17-94. A gondolkodás és a létezés koegzisztenciájának kérdésével a spinozai szubsztancializmus Nietzsche filozófiájára gyakorolt hatását tárgyaló harmadik exkurzusban foglalkozunk bővebben.

${ }^{171}$ Vö. Green (2002) pp. 36-57.
} 


\section{3. Az „aktív differencia” mint örök visszatérés: a Zarathustra}

Az 1882 áprilisa és novembere közötti pár hónapra esik Nietzsche kérész-életü barátsága Lou von Saloméval. Kettejük viszonyát illetően, mint Nietzsche élete és gondolkodása kapcsán szinte minden vonatkozásban, megoszlanak a vélemények. Azonban ha beérjük azzal, hogy igyekszünk a különböző interpretációk „legkisebb közös többszörösét” felmutatni, annyit mindenesetre megállapíthatunk, hogy Lou extrém módon inspirálta, ösztönözte, felajzotta Nietzschét; a fillozófus pedig, talán nem túlzás ezt állítani, az első állomása volt annak a folyamatnak, melynek során a különc gondolkodású orosz lány a századforduló kulturális életének egyik legmeghatározóbb egyéniségévé vált. ${ }^{172}$ Lou szerint a Nietzsche által tökélyre vitt aforisztikus forma nem merül ki a sajátlagosan nietzschei szellemiség tökéletes formába öntésében, hanem épp ellenkezőleg: a fillozófusnak a „pusztán aforisztikus" stíluson való túllépésre, gondolatainak egységbe foglalására irányuló szándékát, törekvését jelzi. ${ }^{173}$ A belátás, miszerint az emberi értéktételezés alapvetően ösztönös jellege szöges ellentétben áll az időközben fogalmivá szilárdult gondolkodásunkkal, vagyis a kantischopenhaueri-wagneri nyomvonalról való letérés elsősorban Nietzsche hangoltsága és érzékelöképessége megváltozásának a következménye volt; állítja Lou. Ez, és csak ez vezethetett azután egy egészen új világnézet kialakulásához, melyről csak a metafora nyelvén, a perspektíva örökmozgó terében, az aforizma lezáratlan keretei között lehet beszélni. Nietzsche gondolkodásmódja ugyanis - legyen szó ismeretelméletről vagy morálfilozófiáról, esztétikáról vagy misztikáról - mindig ugyanazt az ívet futja be: elöször is a modern érzékelés-tudomány legutóbbi eredményeihez való kapcsolódás, majd saját kedélyállapotának felforgatása az adott eredményekkel való legmesszebbmenő szembesülés következtében, és végül a mindebből következő új elmélet. Hiszen, mondja Lou, épp a gondolkodás, és a másik oldalról a szenvedélyek relativitásának belátása - és megtapasztalása! - vezette Nietzschét arra a következtetésre, hogy az ember öröktől fogva két, egymással antagonisztikus

\footnotetext{
${ }^{172}$ Vö. Lou Andreas-Salomé: „Visszaemlékezés.” Ford. Schleicher Dóra. In: EX Symposion. 1994. Nietzschekülönszám.156-160. o. „,.. ha valaki belehallgatott volna beszélgetéseinkbe, azt hihette volna, hogy két ördög társalog (...) Ugyanaz nyügözött le benne, mint ami belső elfordulásra kényszerített. (...) nagyon ritkán vagy soha sem fordult még elő, hogy két ember ilyen szövetséget kötött volna, amelyben ennyi meggondoltság, ugyanakkor ennyi meggondolatlanság van együtt.”

${ }_{173}$ Lou a „Versuch”, azaz „,kísérlet”, „próbálkozás” kifejezést használja. Ld. Lou Andreas-Salomé: Nietzsche in seinen Werken. Insel Verlag, 1983. 187. o.
} 
ellentétben álló „túlságosan is emberi” attitűd falai közé van bezárva. Adva van egyrészt végsőkig feszített intellektualizmusunk, amely életet a gondolkodásnak, érzékit a megértésnek rendel alá; a másik oldalon pedig ott áll az életösztön, mely az igazságot puszta eszköznek tekinti önnön kiteljesedésének szolgálatában. Épp ezért olyan fontos annak felismerése, hogy önmagunkat meghaladni csak voltaképpeni ösztön-lényegünk fel- és elismerése révén lehetünk képesek. Nietzsche kései írásainak központi gondolata nem más, állítja Lou, mint az ösztönök ezen „,úlságosan-is-emberi” természetének belátására épülő antropológia; az 1880as évek Nietzschéjére és nietzschei filozófiájára egyaránt érvényes, hogy ,a fájdalmas fizikai folyamatok, melyek [Nietzschénél, L. E.] addig a különböző megismerési folyamatok okai és kísérőjelenségei voltak, immár magává a megismerés tartalmává váltak."174 Sőt, már a kezdetektől, a schopenhaueriánus időktől fogva minden egy irányba, a „mindenen uralkodó” és „önmagának szolgáló” eljövendő emberiség víziójához vezet. ${ }^{175}$ Nietzsche ugyanis, saját bevallása szerint, éppen a schopenhaueri filozófia révén nyert bepillantást a lényegileg életellenes gondolkodásmód mechanizmusaiba. ${ }^{176}$

„Itt ültem, s vártam, vártam - semmire, / túl jón s rosszon, a táj fényeire / s árnyaira, merő játék, merő / tó és dél, merő céltalan idő. / S az Egy Kettővé lett egy perc alatt - / s Zarathustra előttem elhaladt." ${ }^{177}$ Zarathustra Nietzschéből született, az ő megkettőződése leveleiben számtalanszor nevezi „fiának”. A Lou Saloméval és Rée-vel történő szakítás után Nietzsche úgy érzi, számára a magány rendeltetett. Zarathustra, miután visszatér az emberek közé, meg-nem-értésükbe, gúnyos nevetésükbe ütközik, és úgy dönt, attól kezdve nem követőket, hanem tanítványokat keres magának. A Naphoz hasonlónak érzi magát, amelynek alászállásában ott rejlik a felemelkedés ígérete: nincs többé létrejövés és elmúlás, csak folyamatos változás, örökké keletkező élet. Az ember kell, hogy legyen a föld értelme, saját magunk számára kell okká válnunk, a földhöz való hüség okává. Nincs szükségünk többé túlvilágra, ha a föld értelmében hiszünk, és ha képesek vagyunk felülemelkedni - saját magunkon. Az alábukás és a felemelkedés szükségszerü mozgása az önmagán munkálkodó embernek, hiszen „híd ő és nem cél”, ${ }^{178}$ mondja Zarathustra. Az ellentmondást a

\footnotetext{
${ }^{174}$ Andreas-Salomé(1983) s. 211.

${ }^{175}$ Ld. u. ott

${ }^{176}$ U. ott s. 185-230., különösen s. 185-192.

${ }^{177}$ Friedrich Nietzsche: „Sils Maria.” Ford. Lator László. In: Nietzsche(1989) 28. o. Megjegyzendő, hogy a vers alapjául szolgáló sorokat Nietzsche még a Zarahtustra első részének keletkezése idején jegyzi le. (KSA 10.157 „Ganz Meer, ganz Mittag, ganz Zeit ohne Ziel

Ein Kind, ein Spielzeug

Und plötzlich werden Eins zu Zwei

Und Zarathustra gieng an mir vorbei.")

${ }^{178}$ Z I:165
} 
különbségben feloldó metaforika az a tapintható energia, mely a harmadik könyv csúcspontjáig hajtja a müvet.

Nietzsche filozófiájának meghatározó momentuma, az alapvető életigenlés, mint láttuk, már A tragédia születésében megjelenik, a dionüszoszi szétszaggatást a sokszoros, differenciáló igenlés szimbólumaként értve, ellentétben a dialektikus különbség tisztán negatív jellegével. A szellem felszabadításának igénye megelőlegezte egy teljesebb átalakulás igényét, azonban a „szabad szellem trilógiának” az örök visszatérés gondolat propedeutikájaként való Caygill-féle, korábban ismertetett értelmezése ${ }^{179}$ kétségtelenül kiegészítésre szorul. Zarathustra a „három átváltozásról”180 szóló beszédében adja meg az önteremtés korábban jelzett egzisztenciális követelményének végső értelmét; és ezzel a manőverrel egyszersmind a most kezdődő mitikus utazás ontológiai jelentőségét is sejteti. A szellem a teve alakját öltve magára vesz mindent, amit csak elbír, és terhe alatt rogyadozva megy, amerre hajtják, sivatagról sivatagra. Oroszlánná változva azonban a szellem végre megszabadul terheitől; számára nincs többé „kell”, de még így sem elég erős, hogy azt mondja: „akarom”. Az oroszlán „szent nemet” mond a „kötelmekre”, így teremtve meg a teremtés szabadságát. Miután felszabadult addig terhei alól, az immáron szabaddá vált szellem a gyermek ártatlanságával születik újra: számára minden első, „szent igenje” az igennél és nemnél korábbi, teremtő affirmáció. Ha Zarathustra tanítványául szegődünk, utazásunk végére a „legnagyobb teher” nyomja majd a vállunkat, de mégis képesek leszünk táncolni súlya alatt - ezzel a rettentő bejelentéssel hagyott magunkra Nietzsche $A$ vidám tudomány végén. Zarathustra gondolatainak fonalát követve a lehető legveszélyesebb útra indulunk, de végül „saját világát nyeri el a világa-vesztett”. ${ }^{181}$ Kövessük tehát végig a teremtők útját!

Zarathustra a mű kezdetén elmeséli, hogyan szabadult meg a „más-világolók”182 bűvköréből, akik álomnak és költeménynek tekintik a világot, melyet valamely isten teremtett, hogy létezzen valami rajta kívül. Holott egyedül a nemakarás fáradt nihilizmusa képes isteneket és más-világokat teremteni, mert nem elég erős ahhoz, hogy önmagát, a testét és a földet akarja. Az „Önmaga" ${ }^{183}$ hatalmasabb az Én-nél; több, mint tudatosság - ösztön, hús és vér, folyamatos önmeghaladás: a föld értelme. A szenvedélyek az erkölcs felett állnak,

\footnotetext{
${ }^{179}$ Caygill (1991)

${ }^{180}$ Z I: $455-522$

${ }^{181} \mathrm{Z} \mathrm{I}: 516$

${ }^{182}$ Vö. Z I:605-I:704 „A más-világolókról.”

${ }^{183}$ Vö. Z I:705-I:764 „A test becsmérlőiröl.”
} 
mert testünknek nem tudunk parancsolni értelmünkkel, csak ha belátjuk, hogy az „önmaga”: maga a test. Az értelem az „önmagam” értelme, hiszen „,szellem a vér”; aki pedig a vérével akar írni, annak bátornak, sőt merésznek kell lennie; az ilyen emberek a magasban sem félnek, kinevetik a veszélyt, és a „pillangók és szappanbuborékok” táncát járják. Az ilyen emberektől tartanak a ,jók”, mert ők a régit akarják, a feltörekvők, a nemesek pedig mindenre veszélyesek, még önmagukra is, hiszen ők a megsemmisítők. De vékony a határ a hedonizmus és a heroizmus között, a nemes szellem tehát nem a kéjért, hanem a felszabadulás reményében pusztít. De tévednek a test megvetői, mikor a földtől való elfordulást prédikálják és a túlvilágba vetik minden reményüket; az önmegtagadás, a részvét, a gyönyör bünné nyilvánítása a halál győzelmét hirdeti az élet felett. A hős nem a közös ellenségen akar felülkerekedni, hanem önmagának választ ellenséget, és legfőbb ellenfele éppen ő maga. Az ember híd az emberfeletti emberhez, útja a szivárványé, ${ }^{184}$ mely a sorsválasztás helyére vezet.

A valódi szabadság magánnyal jár, a remete számára a barát mindig harmadik, akinek szemében „önmagát” látja tükröződni, hiszen az Egy mindig már eleve Kettő, alanya és tárgya is saját gondolatainak. Az ember ugyanis csak szubjetum-objektum viszonyban képes elgondolni mindent; ,értékkel” ruházza fel a dolgokat, hogy így a maga számára valóvá tegye őket, és az idők során elfelejtette, hogy ezek nem magánvalók, hanem épp ellenkezőleg: értéküket magából az értékelésből nyerik. Aki pedig értéket teremt, annak előbb rombolnia kell, hiszen minden értékelés a rangsort, a különbség rendjét szolgálja. A teremtéshez ártatlanság kell, ez különbözteti meg a valamitől való és a valamire való szabadságot: az előbbit a múlt, utóbbit a jövő határozza meg. A teremtés mindig önfeláldozás: magunkból kell valami nálunk nagyobbat teremtenünk, el kell tékozolnunk önmagunkat a teremtésben, elmúlásunk csak így lehet beteljesülés - ez a dionüszoszi pesszimizmus igazi jelentése. ${ }^{185} \mathrm{Az}$ „adakozó erényről”186 mondottakkal Zarathustra búcsút mond az embereknek,arra kérve őket, tagadják meg őt, hogy önmagukká válhassanak, de ő maga sem tesz másképp: lemond az emberekről, hogy aztán majd visszatérve közéjük más szemmel kereshesse és más szeretettel szerethesse őket. Zarathustra megtagadja az ember iránti részvétet, és ezt kéri magától az embertől is, hogy eljöhessen az emberfeletti ember ideje.

Nem szabad részvétet éreznünk egymás iránt, hiszen önmagunkkal szembeni részvét az; szégyellnünk kell ezt a részvétet, mert a szenvedés és a büntudat moráljához láncol. A

\footnotetext{
${ }^{184}$ Vö. Z 416-417. o. 118. lj.

${ }^{185}$ Vö. Z I:1837-1838, illetve I:2066-2073

${ }^{186}$ Vö. Z I:1928-2074 „Az adakozó erényről.”
} 
teremtő szeretete ennél hatalmasabb, hiszen teremtve önmagát tékozolja el. Istent mi teremtettük félelmeinkből és szenvedésünkből, és feláldoztuk neki magát „az embert”. Az erkölcsi világrend alapja a fizetség és a büntetés, szó sincs tehát önzetlenségről, csak félelemről: ez az alapja hitünknek és erényünknek. Nietzsche az Önmaga erkölcsét hirdeti, mely szerint az ember a föld értelme. ${ }^{187} \mathrm{Az}$ „,egyenlőség prédikátorai” ${ }^{188}$ hazugok, valójában bosszúra szomjaznak a felettük állókkal szemben; a bölcs ,,hasonlatokban szól ${ }^{189}$ - a szabad szellem pedig a magánnyal hallgat. ${ }^{190}$ Zarathustra fény, és a sötétben minden a fény felé törekszik; de vajon nem ugyanarra vágyna maga a „világoló” is? Zarathustra az Életbe szerelmes, az „alapja-nincsbe”, ${ }^{191}$ de az Öröklét és a Bölcsesség pusztán az Élet csábító, női fortélyai: elérni öket lehetetlen. Az ifjúság elmúltával nem hiszünk többé a „látomásoknak és jelenéseknek", ${ }^{192}$ akaratunk szilárdan kapaszkodik a talajba; de az élet megőrzi az ifjúságot és a megváltás reményét, hiszen minden elmúlt napra új virradat köszönt. Az élet az, aminek „mindétig fölül kell múlnia önmagát”, ${ }^{193}$ és hasonlóan áll a dolog a tudással: nincs „,szeplőtlen megismerés"; a magasságot csak a mélységbe alábukva tapasztalhatjuk meg. Az Önmaga: test és szellem organikus egysége, maga is test, s egy napon az embert felülmúló ember lesz majd a föld értelme. A tengerek kiszáradása, a remény eltűnése fenyegeti a világot, mégsem szünhetünk meg rombolni, mert csak így válhatunk teremtőkké; ki kell kacagnunk a kísérteteket. Csak akkor van értelme élni, ha hiszünk a megváltásban, mert az eljön, ha akarjuk - az akarat az, ami képes a véletlenből szükségszerüt csinálni, „megváltani az elmúltakat, és »Így akartam! «-má újrateremteni minden »Megesett«-et”. ${ }^{194}$ De a múltnak még az akarat is foglya, hiszen visszafelé akarni, a múltat megváltoztatni képtelenség. Így lett az ember a büntudat foglya, az akarat pedig - és vele együtt az élet is - maga a bün. Az akarat megváltása csak azáltal lehetséges, hogyha azt, amit egyszer már akartam, örökké akarni fogom: így lesz akaratom teremtô. ${ }^{195} \mathrm{Az}$ Übermensch, az embert felülmúló ember ideje azonban még nem jött el, mert még nem vagyunk képesek „,teremtve önmagunk fölé nőni”, 196 túlságosan ostobák és gyengék vagyunk ahhoz, hogy önmagunk eltékozlásával híddá váljunk az Übermensch eljöveteléhez - de vajon képes-e erre bárki magán az Übermenschen kívül?

\footnotetext{
${ }^{187}$ Vö. Z II:373-374: „Erényetek a legbecsesebb Önmaga tibennetek. Tiétek a gyürü szomjúhozása; hogy újra elérhesse önmagát - minden gyürủ ezért gyürüzik egyre, és ezért forog." (kiemelés tőlem, L. E.)

${ }^{188}$ Vö. Z II:534-63 „A tarantulákról.”

${ }^{189}$ Z I:1978-1979, illetve II:542

${ }^{190}$ Vö. Z II:665-681

${ }^{191}$ Vö. Z II:816-817

${ }^{192}$ Z II: 875

${ }^{193}$ Z II: 1040

${ }^{194}$ Z II:1790-1791

${ }^{195}$ Vö. Deleuze (1999) 113. o.

${ }^{196}$ Z I:753
} 
Zarathustra maga sem volt még elég ártatlan ahhoz, hogy ne szégyenkezzen szavainak súlyán, ${ }^{197}$ így magukra hagyta tanítványait a boldogságos szigeteken, hogy még utoljára tengerre szálljon. A hajósoknak mesél a legkínzóbb „látomásról és talányról”, ${ }^{198}$ mikor a „nehézkedés szelleme”, ${ }^{199}$ ez a gonosz kis törpe telepedett a vállára, és vitette magát a hegyen fölfelé. Ö súgta Zarathustra fülébe a legnagyobb talányt: mi van, ha minden, ami ez a pillanat, már volt egyszer ugyanígy; ha a múlt és a jövő, az a két örökkévalóság találkozott már ugyanitt, és még fog is, végtelenszer? De egyszer csak eltűnt a törpe, és Zarathustra egy pásztort látott a földön feküdni, a szájából egy kígyó lógott; ám a pásztor végül leharapta a kígyó fejét, és a veszélytől menekülve a legcsodásabb nevetéssel nevetett, melyet Zarathustra valaha is hallott, és amelyet azóta is vágyik hallani. Ki volt a pásztor, és mivé vált nevetésében? - ez a legnagyobb talány. ${ }^{200}$ De Zarathustra végül ismét partra száll, és az emberek közé megy, azok viszont egyre csak kisebbednek; egymáshoz simuló homokszemek sivatagában jár. Ö mégis közéjük akar menni, mert az embert érdemes még szeretni, hiszen az egy Isten halálával végre újból övé lett a világ. Barlangjába térve a „hatalmas délidő”201 jöttét várja, az átváltozás idejét, mikor minden átfordul, és a „három gonosz”, ${ }^{202}$ a gyönyör, az uralomvágy és az önzés - üdvözülhet. Hiszen a legnagyobb teher az ember számára saját maga, de nem az Önmaga, hanem az Én, mely idegen terheket cipel. Most, mikor a Föld eloldódott Napjától, minden folyik, nincs kapaszkodó, csak egy bárka - a „talán”, hiszen ha semmi sem biztos, akkor akár a semmibe is juthatunk. Hét napig beteg volt a Zarathustra, és a hetedik napon állatai szembesítik tanításával; az örök visszatérés gondolata először az ő szájukból hangzik el. A talány megoldódott: maga Zarathustra volt tehát a pásztor a látomásban, aki leharapta a halált hozó kígyó fejét, és a „legsúlyosabb gondolat”203 terhétől ily módon megszabadulván ,átváltozott és fény vonta be: nevetett!"204 Állatai kimondják: véget ért alábukása, eljött az ideje, hogy az örök visszatérés tanítója legyen. Az életbe szerelmes Zarathustra pedig az „Igen és Ámen dalával” hét pecsétet üt az „ötödik Evangéliumra”. „Az Igen és Ámen dala” Nietzsche-Zarathustra szerelmi vallomása az Örökléthez, melybena dionüszoszi filozófia örök termékenyége iránti vágy szólal meg.

\footnotetext{
${ }^{197}$ Vö. Z II:233-234 „Gyermekké kell még lenned, hogy ne szégyenkezz.”

${ }^{198}$ Vö. Z III:107-268 „A látomásról és a talányról.”

${ }^{199}$ Ld. Z III:135-140, illetve III:1243-1378 „A nehézkedés szelleméről."

${ }^{200}$ A sas és a kígyó hagyományosan Zarathustra szent állatai, egyik a bölcsességet, másik a büszkeséget jelenti, de a sas-kígyó szimbolika ennél sokkal gazdagabb. A sas a magasság, a kígyó a mélység, a „nehézkedés szelleme", de Zeuszt is ábrázolták sasként, mely kígyót visz a szájában, Dionüszoszt pedig hol kígyókkal övezve, hol éppen pásztorként.

${ }^{201}$ Ld. Z I:2066-2073

${ }^{202}$ Vö. Z III:1089-1242 „A három gonoszról.”

${ }^{203}$ Vö. Z II:257-258 „,.. mi nehezebb a nehéznél és feketénél is feketébb”

${ }^{204}$ Z III:261-262
} 
Ugyanakkor az Örökkévalóság megtermékenyítése nem jelent eggyé-olvadást, hiszen az örök visszatérésben elsősorban a vágy tér vissza, az önmaga kiteljesítésére törő hatalom akarása, amely a hiányt a beteljesülésig hajtja, hogy ezzel megfossza mindenétől. A visszatérés első mozdulata a szent igenlés, amely magát a változást, a különbség visszatérését igényli. ${ }^{205}$

Zarathustrát még utoljára megkísérti a részvét a „fölmagasló ember”,206 iránt, mikor találkozik a két királlyal (a morális és az immorális szimbólumával), a piócás emberrel (az intellektuális lelkiismeret szimbólumával), a varázslóval (a „költő”, a szenvedést álcázó „,rossz lelkiismeret” szimbólumával ${ }^{207}$ ), az utolsó pápával (a vallás szimbólumával), az utolsó emberrel: Isten gyilkosával, az „önkéntes koldussal”208 (a csordalény szimbólumával), és utolsóként saját, vele vándorló árnyékával, és barlangjába invitálja őket. A fölmagasló embereket az „utolsó vacsorán”209 megbékíti rendeltetésükkel, ők lesznek a híd az emberfeletti ember számára, ők az ,átaljutásban alábukók”. ${ }^{210}$ Azokat látjuk most Zarathustra körül, akik ellen mindvégig harcolt; itt van a megismerés, a morál, a vallás, sőt még a müvészet is: mindennek buknia kell, hogy hamvaiból születhessen újjá, ahogyan azt Zarathustra is tette. A felmagasló embernek el kell tékozolnia magát, hogy adományából belőle magából - megszülethessen az embert felülmúló ember. De a fölmagasló embereket is megkísérti még utoljára Isten, akit gyilkosa, az utolsó ember támasztott fel; de szamár képében, s istentisztelete így már csak ,,szamárünnep”, ${ }^{211}$ hiszen „,nem a düh gyilkol, hanem a nevetés". ${ }^{212} \mathrm{~S}$ a szamárünnep másnapján megszületnek végre Zarathustra gyermekei: a galambok és az arany oroszlán. A Zarathustra negyedik könyvét Gary Shapiro Nietzsche hihetetlen gondolkodói és költői találékonysága termékének tekinti, az igazság metaforikusságának tragikomikus ünnepeként. Shapiro felfejti a negyedik rész dramaturgiai és retorikai kódjait, a szamárünnepet szatírjátékként mutatva be, ahol a felmagasló emberek szájából egyszerre szólal meg az igaz és a hamis; csupa paprikajancsi, Zarathustra udvarának bolondjai. „Az alvajáró dalában” Zarathustra ugyan voltaképpen még saját igazságát is

\footnotetext{
${ }^{205}$ Vö. Z III:2400-2402: „Soha nem találtam még asszonyt, akitől gyermeket akartam volna, hacsak nem ezt az asszonyt, akit szeretek: mert téged szeretlek, ő, Öröklét!”. Erről bővebben lásd: Paul Valadier: „Dionüszoszt a Megfeszítettel szemben.” Ford. F. Zs.. In: EX Symposion. 1994. Nietzsche-különszám. 139-145. o.

${ }^{206}$ Ld. Z IV:1548-1550, illetve vö. IV:1551-1860 „A fölmagasló emberről.”

${ }^{207}$ Vö. Z IV:606-610

${ }^{208}$ Vö. Z IV:1014-1122 „Az önkéntes koldus.”

${ }^{209}$ Z IV:1486-1550

${ }^{210}$ Z I:165-166 „Attól nagy az ember, hogy híd ös és nem cél: hogy átaljutás ő és alábukás - szeretni azt lehet benne csak."

${ }^{211}$ Vö. Z IV:2407-2519 „A szamárünnep.”

${ }^{212} \mathrm{Z}$ I:940
} 
megkérdőjelezi, de egyúttal rehabilitálja is azt az örök visszatérés mámoros és fájdalmas énekében. $^{213}$

A müvet a beszéd és a hallgatás váltakozásának stratégiája müködteti. Zarathustra visszatér a magányból az emberek közé, majd a közönség helyett a tanítványokat választja, a kiválasztottak számára prédikál, végül ismét magányába vonul, hogy aztán már csak a felmagasló emberekhez szóljon; de az örök visszatérés hatalmas gondolatát állatai mondják ki, ő csak énekel róla. Nietzsche maga majd csak szellemi összeomlása után beszél az örök visszatérésről, először megteszi helyette a démon, majd Zarathustra és állatai, vagy éppen Dionüszosz. ${ }^{214}$ Hiszen Nietzschénél minden örökké visszatér, minden az örök visszatérés gondolatának része, így ő maga is; mindez pedig éppen Isten halálának következménye. A Napjától eloldozott Földnek nincs szüksége új napokra, csak önmagára; nincs többé két világ, csak ez a folyamatosan alakuló, de az alakulás örök visszatérésében mégis ugyanaz: a teremtetlen ősidő. Az örök visszatérés azt jelenti, hogy a múlt és a jövő metszéspontjában pillanatról pillanatra vándorol az öröklét, mindig ugyanúgy, amíg világ a világ. De vajon mi vár az örök visszatérés emberére? A legmagányosabb magány, hiszen Isten halála után magára maradt, és tudatában is van magányának. Ugyanakkor „hetednapi magány” ez, a teremtő magánya az újra végtelenné váló világban; ez az emberi létezés tragikuma, és valóban istenekké kell válnunk ahhoz, hogy könnyedén, nevetve táncoljunk rajta keresztül. Mégis, ha képesek vagyunk akaratunkkal teremteni, méghozzá önmagunkat, akkor az örök visszatérés végtelen folyamatának részeként magát az Egészet is teremtve-alakítjuk, így lesz a világ

\footnotetext{
${ }^{213}$ Vö. Gary Shapiro: „Fesztivál, karnevál és paródia a Zarathustra negyedik könyvében.” Ford. Kis Gábor. In: Gond, 1999/23-24. 172-189. o. Online: http://www.c3.hu/ gond/tartalom/23-24/frashapiro.html

${ }^{214}$ Vö. Heller Ágnes: „Mit számít, kinek beszél? A megszólított esete Nietzsche Zarathustrájában.” In: Gond, 1999/23-24. 158-171. o. Online: http://www.c3.hu/ gond/tartalom/23-24/fraheller.html,,Nietzsche Én-jei számosak, de Zarathustra szövegeiben mintha egyetlen Én jelenne csak meg, egyetlen perspektíva. S éppen ez, ami a rejtély. Mindenesetre nekem ez volt a rejtély, s erre kerestem a megoldást. Úgy láttam, úgy látom, hogy a Zarathustra szerzője bizony ugyanaz a Nietzsche, azaz ugyanaz a többszörös énủ Nietzsche, mint más könyveiben, csak éppen áthelyezte a paradoxikalitást a szövegből a szöveg elmondójának személyiségébe. $A$ tanitás lehet apodiktikus, de a tanitó nem az, vagy legalábbis csak az elsö, felületes pillantása az. A tanitó, a próféta prédikál, butit, gáncsol, igazságokat hirdet, de ugyanez a tanitó distanciával és iróniával néz nem pusztán saját tanitására, nem is elsösorban arra, hanem inkább arra a szerepre, melyet játszik. Ezért (is) kell táncolnia, könnyedén. Ezért (is) kell mondania vagy érzékeltetnie, hogy mindez játék; ha akarjuk egyfajta szatírjáték, müvészkedés és büvészkedés, hogy a hegy meg a barlang színpadi kellékek, és hogy a nézők ugyanúgy kifütyülhetik, ahogy tapsolhatnak neki. S föleg hogy ő olyan próféta akar lenni, aki kihúzza, kitörli önmagát mint prófétát. (...) Jól értettem Zarathustrát? Nemde azt mondja nekünk, hogy senkiben se higgyünk, benne sem, hanem inkább legyünk önmagunk? Hogy ne öt kövessük, inkább magamagunkat kövessük, s hogy csak ha öt megtagadjuk, akkor tudunk önnönmagunkká válni? Hogy aki teljesen önmagává vált, aki saját akaratát, saját sorsát, végzetét követi, aki újra tudja választani nemcsak magát, hanem egész múltját is (hiszen ki más tudná elviselni az örök visszatérés gondolatát?) az ember az embert fölülmúló ember? De ha ez így lenne, akkor Zarathustra semmit sem taníthatna. Csak azt prédikálhatná hiveinek, tanitványainak, hogy ne legyenek se tanitványok, se hivők, se követök - hanem kizárólagosan önmaguk. Hogy azzá váljanak, amik. Valamit, amit nem lehet tanitani." (kiemelések tőlem, L. E. Zárójelben: Nietzsche számtalanszor írta tanítványának, Lou-nak: „Legyen azzá, aki!”)
} 
Ugyanannak a hatalomakarás által müködtetett örök visszatérése. Az amor fati a szükségszerűség és a véletlen egylényegűségének kinyilvánítása és igenlése, a saját „átmeneti” és magányos létemre mondott igen; hiszen a pillanat egyszeriségében örökké magamban vagyok. Tatár Gyögy az örök visszatérés gondolatát a „logosz-krisztológia”, vagyis a logosz inkarnációjáról szóló tanítás tárgykörébe sorolja, ezzel pedig két alapvető megállapítást tesz: 1. az örök visszatérés mindannyiunk sorsa, és 2. az örök visszatérés tanítása viszont kizárólag Zarathustra sorsa. Ö ugyanis nem prófétája az örök visszatérésnek, hanem tanítója, de oly módon, mint Krisztus, aki maga volt a tanítás, élete pedig a példa. Egy napon, mondja Zarathustra, az ember kell, hogy legyen a föld értelme, ezt teljesíti be az örök visszatérés, mely mindannyiunk sorsa, a folyamatos ön-meghaladásban örökké visszatérve mi magunk vagyunk az emberfeletti ember eljövetelének „okai”. Zarathustra maga éppen azért nem mondja ki soha az örök visszatérés gondolatát, mert ő maga is a gondolat része. ${ }^{215} \mathrm{De}$ az „átmeneti” vagy „posztumusz” lét sem mulandóságában, sem magányában nem szánandó, hanem tragikus. Hiszen mit is jelent az, hogy csak keletkezés van? Azt, hogy nincs többé túlvilág, csak túlhaladás; az ellentétek megszüntek létezni, és nem a dialektikus egymástmegszüntetve-megőrzés módján, hanem úgy, hogy egyik a másik meghaladása révén keletkezik. Távolságukat az „aktív különbség” őrzi, mely sosem szünik meg különböztetni és különböződni; mint a hatalom akarásának operatív ereje. ${ }^{216}$ Hans-Georg Gadamer felhívja a figyelmet arra a disszertáció második részében általunk is tárgyalt tényre, hogy Deleuze és Derrida Nietzsche-értelmezése egyaránt polemizál a heideggeri interpretáció alapvető logocentrizmusával. A két említett posztmodern gondolkodó ugyanis abból indul ki, hogy Nietzsche gondolkodása éppen a „lét értelmének”, az eleve adott logosznak a tagadására irányul, amennyiben azt állítja: minden interpretáció, az igazságok pedig metaforák, maga a hatalom akarása pedig, mely az igazság akarását is hajtja, a teremtő átformálás akarása. A Zarathustra koncepciója zseniális, mondja Gadamer, hiszen tökéletesen fejezi ki a teremtő igenléstől elvárt radikális ártatlanság közvetlensége és az örök visszatérés gondolatának fent jelzett kimondhatatlansága közti ellentmondást, melyet Gadamer a „közvetített közvetlenség paradoxonának"217 nevez. A Zarathustra az önreflexió ördögi körébe bonyolódott

\footnotetext{
${ }^{215}$ Vö. Tatár György: Az öröklét gyürüje. Nietzsche és az örök visszatérés gondolata. Gondolat, Bp., 1989, 8994. o.

${ }^{216}$ Vö. KSA 9.643 („Zuerst das Nöthige - und dies so schön und vollkommen als du kannst! „Liebe das, was nothwendig ist" - amor fati dies wäre meine Moral, thue ihm alles Gute an und hebe es über seine schreckliche Herkunft hinauf zu dir”), illetve 9.651 („Sähest du feiner, so würdest du alles bewegt sehen: wie das brennende Papier sich krümmt, so vergeht alles fortwährend und krümmt sich dabei”).

${ }^{217}$ Hans-Georg Gadamer: „Zarathustra drámája.” Ford: Biczó Gábor. In: Gond, 1999/23-24. 7-20. o. Online: http://www.c3.hu/ agond/tartalom/23-24/fragadam.html
} 
szellemfelszabadulásáról, igent-mondásra való szabaddá-válásáról szól; ez Nietzsche tanításának lényege. ${ }^{218}$

Az örök visszatérés gondolata kétségtelenül a legproblematikusabb az életmü egészén belül; Nietzsche maga is érezte szinte felbecsülhetetlen súlyát, melynek eredete éppen a gondolat bizonyíthatatlanságában, minden interpretációs keretet szétfeszítő radikális paradoxalitásában rejlik. Adva van egy alig elgondolható, kimondhatatlan gondolat a véletlen szükségszerüségéről, mely örökké Ugyanakként tér vissza, és visszatérésében folyamatosan újratermeli önmagát az ,aktív különbség”, az önmagát akaró akarat konstitutív mozgása révén. Túl az idealizmuson, túl a dialektikán, túl a metafizikán - hogyan igazolható mindez? Nietzsche gondolatának elgondolása végül így válik nagyobb teherré a régi táblák súlyánál, de ez így szükségszerü: gondolata nem lett volna a legsúlyosabb, ha elveszíti azt a tragikusan igazolhatatlan jelleget, amely az emberi létezés mint olyan legsajátabbja. „Tiétek a gyürü szomjúhozása, hogy újra elérhesse önmagát - minden gyürü ezért gyürüzik egyre, és ezért forog”219 - mondja Zarathustra a második részben. A „gyürü szomjúhozása” a beteljesülés, az azonosság iránti legelemibb vágyunkat jelenti; vágyódásunkat a bizonyosságra, az Öröklétre, az Igazságra: a vigaszra. Már a preszókratikusok tanulmányozása elvezette Nietzschét ahhoz a belátáshoz, hogy az „,azonosság” puszta absztrakció, mert nem létezik a dolgok magánvaló lényege, mellyel fizikai (evilági) létük során azonosulhatnának. Erre a felismerésre épült azután a metaforikus és plurális igazság koncepciója, majd a perspektivikus gondolkodás. Ha pedig nincsen azonosság, akkor a fejlődést, a növekedést, sőt, általánosságban a mozgást sem képzelhetjük el egyik azonosságból a másikba való „ugrásként”. ${ }^{220} \mathrm{~A}$ mozgás mindig csak átmenetként, alakulásként, adott távolság növekedésének vagy csökkenésének folyamataként értelmezhető. Maga a vágy az, ami így működik: a távolságok csökkenése, majd újbóli növekedése a beteljesülés és a hiány ciklusait hozza létre. Minden, ami él, önmagát akarja, hiszen nem lehet csak változás, kell lennie visszatérésnek is. De mégis: ha csak visszatérés lenne, akkor az a hegeli dialektikus idealizmus győzelmét jelentené; a történelemnek lenne célja, és Isten újra elfoglalná helyét a túl-világ trónján. Valóban: Nietzsche elméletét ezen a ponton csak egy lépés választja el attól, hogy visszasüllyedjen a metafizikába. Egyetlen

\footnotetext{
${ }^{218}$ Vö. Gadamer (1999) 12. o.

${ }^{219}$ Z II:373-374

${ }^{220}$ Vö. EE II:198.§ „A természetben nincsenek ugrások. - Akármilyen fejlett is az ember, és látszólag egyik ellentétből ugrik át a másikba, tüzetesebben szemügyre véve a dolgokat, mégis egymásba-illeszkedéseket látunk, ahol az új épület a régiből nő ki. A természettudós feladata: magáévá kell tennie az alapelvet, amikor az életről gondolkodik, hogy a természetben nincsenek ugrások." Nietzsche szerint ugyanis az egyetlen voltaképpeni „ugrás” a természetben az öntudat kialakulása; vagyis az önreflexióra, létezésünk problematizálására való képességünk megjelenése, melynek révén az ember megkülönbözteti magát az állattól.
} 
megoldás van, melynek révén ez elkerülhető: ha maga a változás az, ami állandó - a visszatérés pedig örök. Mikor a törpe, a „nehézkedés szelleme” Zarathustra fülébe súgja: mi van, ha mindez már megtörtént, és megtörténik majd végtelenszer újra, voltaképpen tér és idő végességének rettentő lehetőségét ${ }^{221}$ veti fel, melyből a konstellációk számának végessége is következik. Ha azonban az egész rendszer állandó változásban van, a kontinuum visszanyeri végtelenségét, hiszen ekkor maga a keletkezés az, ami kezdet és vég nélkül való. Nietzsche metafizika-kritikája nem csak az idealizmussal, de a materializmussal is szembehelyezkedik, hiszen utóbbi sem lép ki a metafizika fogalmi kereteiből, és önmagát az idealizmussal szemben, az anyag elsőbbségét hirdetve definiálja. Nietzsche legfőbb problémája tehát, hogy az anyag megismerhetőségébe vetett hit elfedi a puszta reprezentáció és a valóság lényegi különbözőségét; a materializmus tehát végső soron az anyag idealizmusa, az anyag „babonája”. Nietzsche elutasítja a mindent átjáró élet-akarás elsődlegességének elvét, szerinte ugyanis az is pusztán a hatalom akarásának egy speciális formája. Schopenhauernél az akarat abszolút mértékben metafizikai, magánvaló dolog, mely a jelenségvilágban manifesztálódik számunkra-valóként; Nietzsche viszont többször hangsúlyozza: semmi sincs a hatalom akarásán kívül. A hatalom akarása nem a világ mint olyan magánvaló karakterének leírására szolgál, hanemmaga is interpretáció, mely az eleven világ általános karakterének megadása révén lehetővé teszi számunkra, hogy a fenomenális valóság lehető legnagyobb részét uraljuk. A két akarat-koncepció hasonlósága persze tagadhatatlan. Ennél azonban sokkal fontosabb az a tény, hogy Schopenhauer és Nietzsche egyaránt valami tudattalan, irracionális, abszolút testi, ösztönös alapelvre igyekeznek visszavezetni az emberi létezést. Ugyanakkor, míg a kanti-schopenhaueri tradíció felteszi az észlelés és az ismeret egységét biztosító, oszthatatlan és ön-azonos „Én” létezését, Nietzsche tagadja azt; ehelyett vezeti be az „Önmaga” organikus, hierarchikus erő-sokaságként értett fogalmát. Zarathustra a test becsmérőihez szólva a következőket mondja: egyedül a test képes teremtésre, így a „szellem” is valami testi, és a kettő együtt: az Önmaga, az akarat önmagát-akarása, melynek legfőbb vágya, hogy „,teremtve önmaga fölé nőjön". 222

Gilles Deleuze helyesen állapítja meg: Nietzsche számára a világ nem igaz vagy valóságos, hanem élő. Márpedig minden élő organizmus erejének, azaz Önmagának a lehető

\footnotetext{
${ }^{221}$ Vö. pl. BVN-1885, 624. („Brief an Heinrich Köselitz.”) „Daß ich den „endlichen“ d. h. bestimmt gestalteten Raum für unabweislich im Sinne einer mechanistischen Weltausdeutung halte und daß die Unmöglichkeit einer Gleichgewichtslage mir mit der Frage, wie gestaltet der Gesammt-Raum ist — gewiß nicht kugelförmig! zusammen zu hängen scheint - das habe ich Ihnen schon mündlich erzählt."

${ }_{222}^{2}$ Z I:753; Vö. Christopher Janaway: „Nietzsche, the self, and Schopenhauer.” In: Nietzsche and Modern German Thought. Ed. Keith Ansell-Pearson. Routledge, London - New York, 1991, pp. 119-142., illetve Nehamas(1985) pp. 80-81.
} 
legteljesebb kifejtésére törekszik; a hatalom az, ami érvényre akar jutni. Az élet tehát nem lehet más, mint folyamatos akarás - de abban már nem értünk egyet Deleuze-zel, hogy a teremtő potenciál az ún. „kettős affirmáció” (amely a változásban egyszersmind a változás létét is igenli) eredményeképpen adódik az akarat számára. Nézőpontunk szerint maga az önmagát is folyamatosan felszámoló és ugyanakkor újrakonstruáló különbség az, ami egyedül képes „új világokat” teremteni. Deleuze olvasatában a hatalom akarása az affirmációt egyáltalában lehetővé tevő differenciális elem, maga az örök visszatérés pedig a változás és a lét affirmatív egysége - mi azonban úgy véljük, Nietzschénél szó sincs affirmatív egységről, mint egyfajta végcélról, sokkal inkább a különbség megszüntethetetlen aktivitásáról beszélhetünk; ez pedig, mint azt az értekezés második részében részletesen is tárgyaljuk, már eleve kizárja az ontológiai differenciáról való megfeledkezés lehetőségét.

\section{Exkurzus: Hatalom és élvezet: Nietzsche és Spinoza}

Nietzsche az örök visszatérés gondolatának fogantatása idején, 1881 nyarán (július 30án) számol be barátjának, Franz Overbecknek arról a hatalmas jelentőségü eseményröl, melyet a Spinoza filozófiájával való megismerkedés jelentett; úgy érezte, szellemi elődjére, gondolkodásának igazolójára lelt. ${ }^{223}$ Nietzsche öt sarkalatos pontot emel ki, melyekben „magát látja viszont”; a nyilvánvaló eltéréseket pusztán a kor és a kultúra különbözőségével magyarázza. Az öt közös pont öt „tagadás”; nevezetesen az akaratszabadság, a teleológia, az erkölcsi világrend, az önzetlenség, és a „gonosz” tagadása. Spinoza racionalista metafizikájában Isten maga a szubsztancia, amelynek „,fogalmát más dolog fogalma nélkül alakíthatjuk ki", ${ }^{224}$ a szubsztancia attribútumai a kiterjedés és a gondolkodás (szemben a karteziánus dualizmussal, mely test és lélek eredeti ellentétéből indul ki); a változó egyedi dolgok, vagyis a világ, és benne az ember is ezen attribútumok móduszai. Azonban míg Istenben a gondolkodás és kiterjedés ugyanaz a szubsztancia, az emberben e kettő az

\footnotetext{
${ }^{223}$ Vö. BVN-1881, 135. („Brief an Franz Overbeck.”) Ich bin ganz erstaunt, ganz entzückt! Ich habe einen Vorgänger und was für einen! Ich kannte Spinoza fast nicht: daß mich jetzt nach ihm verlangte, war eine »Instinkthandlung «. Nicht nur, daß seine Gesamttendenz gleich der meinen ist - die Erkenntniß zum mächtigsten Affekt zu machen - in fünf Hauptpunkten seiner Lehre finde ich mich wieder, dieser abnormste und einsamste Denker ist mir gerade in diesen Dingen am nächsten: er leugnet die Willensfreiheit -; die Zwecke -; die sittliche Weltordnung -; das Unegoistische -; das Böse -; wenn freilich auch die Verschiedenheiten ungeheuer sind, so liegen diese mehr in dem Unterschiede der Zeit, der Cultur, der Wissenschaft. In summa: meine Einsamkeit, die mir, wie auf ganz hohen Bergen, oft, oft Athemnoth machte und das Blut hervorströmen ließ, ist wenigstens jetzt eine Zweisamkeit. - Wunderlich!"

${ }^{224}$ Etika 7. o.
} 
individuum párhuzamos aspektusaiként értendő. Isten a teremtő, míg a világ és az ember a teremtett természet, mely utóbbi így nem fogható fel Isten nélkül. Ebböl persze az következik, hogy minden tudásunk az Istenről mint egyetlen és végtelen szubsztanciáról való tudásból származhat; így tehát a dolgok és az eszmék rendje egy és ugyanazon rend. Csak az affekciókból (ti. az indulatokból) származó zavaros érzéki ismeret vezethet tévedéshez, hiszen a racionális ismeret fogalomról fogalomra (adekvát eszméröl adekvát eszmére) következtet, az intuitív ismeret pedig közvetlenül az abszolútumra vonatkozik.

Mivel minden teremtett létező az első szubsztanciából származik, így annak szükségszerü tökéletességéből a teremtett világ adott, az említett szükségszerüség által determinált elrendezése következik; voltaképpeni szabadságunk tehát abban áll, hogy mindezt fel- és elismerjük. Spinoza gondolkodása azonban mégsem tekinthető panteizmusnak, hiszen nem Isten és a világ azonosságát állítja, pusztán azt, hogy a valóság létének és elgondolhatóságának immanens (!) oka Isten. Antonio Negri „tisztán logikai transzcendenciának” nevezi a Spinoza gondolkodásában felmutatható „antifinalista” tendenciát, melynek révén az ontológiai értelemben szükségszerü egységet a sokféleséggel, a végtelent a végessel közvetíti. Spinoza számára, mondja Negri, az ember mint tudás és mint akarat: aktivitás, méghozzá a kisajátítás, a birtokbavétel értelmében. „A premissza a lét radikálisan univok koncepciója, az argumentáció (az ideológia talaján) radikális ateizmus, a konklúzió pedig az ember materialista koncepciója. [...] Spinoza ontológiai anti-platonizmusa kéz a kézben halad teológiai keresztény-ellenességével. Innen ered az ember mint aktivitás, mint kisajátító hatalom [potentia] materialista koncepciója."225 Az ember, mint szellem és test együttese, lényege szerint vágy [cupiditas] és étvágy [appetitus]; ahol előbbi az utóbbi tudatát jelenti. Ebből Spinoza arra következtet, hogy nem azért vágyunk valamire, mert az adott dolog jó, hanem épp ellenkezőleg, azért tartjuk azt jónak, mert vágyunk rá; ${ }^{226}$ ezért van, hogy az értelem az egyeditől halad az általános felé, és nem fordítva. ${ }^{227}$

Számunkra az Etika III. részében kifejtett affektus-elmélet bír különös fontossággal, melyben Spinoza a különböző szenvedélyeket a geometria rendje szerint, azaz általános törvények révén kapcsolja a cselekvésekhez. Mivel a spinozai rendszerben a szabadság a szükségszerüség elismerésében áll, ez esetben nem is etikáról, hanem az affektusok geometriájáról, vagy még inkább fizikájáról kell beszélnünk. Alaptípusuk tekintetében az

\footnotetext{
${ }^{225}$ Antonio Negri: The Savage Anomaly. The Power of Spinoza's Metaphysics and Politics. Trans. Michael Hardt. Minnesota UP, Minneapolis-Oxford, 1991, pp. 132-133.

${ }^{226}$ Vö. Etika III, 9. tétel, Megjegyzés.

${ }^{227}$ Vö. Negri (1991) pp. 130-136.
} 
affektusok kétfélék lehetnek: a vágy, az öröm, vagy éppen a szomorúság az ún. elsődleges affektusok, míg az összes többi indulat ezeknek valamilyen származtatott formája. Ezen túlmenően Spinoza megkülönbözteti a cselekvéseket [actio], melyek az adekvát ideákból származnak, és amelyek az alapvető affektusok objektivációira mint tárgyakra irányulnak; illetve a szenvedélyeket [passio], melyek az inadekvát ideákból származnak és egy másik személynek az adott dologra adott reakciójára, illetve annak a miénkhez való hasonlóságára vonatkoznak. $^{228}$

Az affektus-elmélet Nietzsche számára oly nagy jelentőséggel bíró alapelve a következő: „Minden dolog - amennyire rajta múlik - arra törekszik, hogy létében fennmaradhasson [conatus sese conservandi]. ${ }^{\text {229 }}$ Azáltal, hogy kiterjedésük révén egymást korlátozzák, a véges móduszok a hatások végtelen hálózatát alkotják, így az affektusok mindig valamilyen affectio, hatás következtében jönnek létre. Tehát az általános hatóképesség [potentia], mint a világhoz való viszonyulás képessége, és a hatalom [potestas] gyakorlásának képessége a móduszok egymással való kapcsolatának függvényében válik lehetségessé. Az ember egyaránt képes hatni és hatást elszenvedni, azonban a szenvedőképesség mértéke jócskán meghaladja a cselekvőképességét. Gilles Deleuze rávilágít: a passzivitás Spinozánál a tökéletlenség, a korlátozottság következménye; így a passzív képesség nem fejez ki semmit, sőt, voltaképpen a szenvedés képessége a cselekvőképesség legalacsonyabb szintjének tekinthetö; a hatóképesség mint olyan a maga teljességében csak az aktivitásban, a cselekvésben nyilvánulhat meg. A módusz szükségszerüsége (tökéletessége, önazonossága) éppen potencialitása révén állítható: végtelen számú variációinak mindegyikében mindig éppen a legtökéletesebb. Mint ilyen, a módusz azonban mégsem lehetőség, hanem aktualitás, mely, létében tökéletes lévén, nem irányulhat többé a létezésre, pusztán a hatásra; ez az irányulás a törekvés [conatus], mely így a létező (vagyis a módusz) hatóképességének mértékét fejezi ki. Ha pedig a módusz lényege a hatás, akkor az erre irányuló törekvés értelemszerüen létezésének fenntartására irányul; így tehát nem létrehozza, hanem fenntartja a létet. ${ }^{230}$ Deleuze 1988-ban hét és fél órás interjút adott tanítványának és barátjának, Claire Parnet-nak, mely Pierre-André Boutang rendezésében Abécédaire címen vált ismertté. Az „ábécében” huszonöt betűhöz huszonöt fogalom tartozik, ezek mentén rajzolódik ki a

\footnotetext{
${ }^{228}$ Vö. Boros Gábor: Spinoza és a filozófiai etika problémája. Ford. Barcza Katalin et al. Atlantisz, Bp., 1997, 133-162. o., illetve Pierre-Francois Moreau: „A spinozizmus mint szenvedélyek politikája.” Ford. Boros Gábor. In: Ész és szenvedély. Filozófiai tanulmányok a XVII-XVIII. századról. Szerk. Boros Gábor, ford. Barcza Katalin et al. Áron, Bp., 2002, 189-200. o.

${ }^{229}$ Etika III. 6. tétel

${ }^{230}$ Vö. Gilles Deleuze: Spinoza és a kifejezés problémája. Ford. Moldvay Tamás. Osiris - Gond, Bp., 2000, 157277. o.
} 
deleuze-i gondolkodás különleges építménye. Az élvezet [joie] kapcsán Deleuze a következő, lényegi összefüggésre hívja fel a figyelmet: a spinozai hatalom [potestas] Deleuze-nél a hatóképesség [potentia] hatása, a hatás élvezete (a francia fordításban a hatóképességet a pouvoir, a hatalmat a puissance kifejezés jelöli); az élvezet pedig minden különös esetében ugyanaz: saját létezésünk élvezete, a nietzschei értelemben a győzelem élvezete, a hatalomgyakorlás élvezete. $^{231}$

Nietzsche szerint Spinoza gondolkodásának ,pszichológiai hátterét” a következő tényezők határozzák meg: 1. a „hedonista szempont” elsődlegessége. Az öröm-érzet mindaddig esetleges és változékony, amíg egyedi dolgokra irányul, de örök és változatlan lesz, ha mindent a saját tulajdonommá változtatok. 2. A „természetesen önző szempont”: az erény és a hatalom azonossága. Nem a természet ellen, hanem a természetért kell harcolnunk, így legerőteljesebb szenvedélyeink nem pusztítanak, hanem kielégülnek. Jó az, ami elősegíti a hatalmat, a rossz pedig az, ami ezzel ellentétes. Az erény az önfenntartásra való törekvés következménye. Nietzsche itt az az Etika IV. részének 7. és 8. definíciójára hivatkozik: „A célon, amelynek kedvéért teszünk valamit, az erre irányuló vágyat értem. Erényen és hatóképességen ugyanazt értem, vagyis [...] az erény, amennyiben az emberre vonatkozik, maga az ember lényege, vagyis természete, amennyiben hatalma van olyan dolgokat előidézni, amelyek pusztán az ő természetének törvényeiből beláthatók."232 A „,cél=vágy, erény=hatalom” teszi hozzá Nietzsche. 3. Az egyedi „gondolkodó” lelepleződése. A tudás ural minden más szenvedélyt, mert ő a legerősebb. Míg az antik gondolkodóknál az ember volt a természet célja, a kereszténységben az ember megváltása az isteni gondviselés célja. Spinozánál a „lelkiismeret mardosása” [conscientiae morsus] a mulandóság fájdalmát jelenti, ugyanis nem igaz az, hogy Isten mindent már eleve sub ratione boni rendezett el,szerinte az isteni, azaz tökéletes szubsztancia tételezéséböl mindössze a tökéletes emberiboldogság örök és megszüntethetetlen lehetőségekövetkezik. Ez azonban Nietzsche szerint „pszichológiai téveszme”, hiszen egy adott dolog tartósságából az általa keltett szenvedély tartósságára következtet, méghozzá a mindenség abszolút megismerhetőségéböl kiindulva. Spinoza voltaképpeni érdeme Nietzsche szerint a tökéletes megismerés lehetőségéhez társuló feltétlen hatalomérzet felismerése; a hatalmi ösztön az, ami végül legyőzi és megszünteti az összes többit. Mindenfajta szomorúság, negatív szenvedély eredete a mulandó dolgok iránti szeretetünk. Ahhoz, hogy tudjam, lehetséges-e a tudás, mondja Nietzsche, tudnom kell, mi is

\footnotetext{
${ }^{231} \mathrm{Az}$ interjú-részlet helye: https://www.youtube.com/watch?v=mHYrxP-0ksU, a szöveg angol fordításának forrása: https://terenceblake.wordpress.com/2013/08/17/english-transcript-of-deleuze-on-joy/.

${ }^{232}$ Etika IV. könyv, 7. és 8. Definíció
} 
ez a „tudás”. De ha nem tudom legalább azt, hogy egyáltalán lehetséges-e számomra a tudás, akkor a tudás mibenlétére vonatkozó kérdést sem tudom értelmesen feltenni. Spinoza affektuselmélete tehát valóban hatalmas jelentöséggel bír a nietzschei metafizika-kritika számára, melynek alapintenciója a kanti Ding an sich, és vele a transzcendentális sematizmus kritikája. Kant alapgondolata, hogy a „tudás” meglétének feltételezése naivitás; szerinte a tudás már eleve: ítélet. Nietzsche azonban rámutat: az ítélet maga is pusztán annak feltételezése, hogy valami valahogyan van - nem pedig tudás. Kantnál minden tudás formája egy szintetikus ítélet, mely általános és szükségszerű érvénnyel bír; a gondolkodás „,örvényessége” mindig a megismerés lehetőségén alapul, ahogy az érzelmeké a lelkiismereten. Ez Nietzsche szerint az „uralkodó elöítéletek erkölcsi ontológiája” [die moralische Ontologie das herrschende Vorurtheil]. Akövetkező kérdés az, miben is áll pontosan az „,aprioritás”, tehát a „tiszta ésszerüség" követelménye? Kant szerint csak a matematikában lehetségesek a priori szintetikus ítéletek, így a metafizika, mint a dolgoknak a tiszta ész által adódó ismerete válik lehetségessé - ez Nietzsche szerint „kérdéses”. A matematika és a metafizika lehetőségfeltételei ugyanis, mint mondja, távolról sem azonosak; az emberi tudás vagy tapasztalati, vagy matematikai. Ezzel szemben az ítélet szintetikus, vagyis a különböző képzetek összekapcsolásából származik - és maga ez az összekapcsolás a priori, tehát általános érvényü és szükségszerü. Ha tehát a szintetikus ítéletek a priori adódnának, akkor az észnek képesnek kellene lennie az összekapcsolásra; az öszzekapcsoltság pedig forma, az észnek tehát formaadó képesség birtokában kell lennie. A tér és az idő Kantnál így lesznek a tapasztalat a priori feltételei. A szabadság elgondolhatóságának feltétele a transzcendentális esztétika. Ha a tér és idő magánvalóként adódik, akkor a jelenségek és a magánvaló dolgok ugyanazok, akkor nem létezik az időtől független jelenség - akkor egyszerűen nem lehetséges a szabadság. A szabadság csak egy olyan lényeg tulajdonságaként gondolható el, amely nincs alávetve az idő feltételeinek, tehát ami nem jelenség, nem képzet - ami magánvaló dolog [Ding an sich]. A jelenségek azért nem lehetnek magánvaló dolgok, mert térben és időben, tehát puszta szemléletként adódnak. Kant szerint az ,állítólagos” pszichológiai szabadság azt jelentené, hogy a képzeteink ösztönöznének minket, mint afféle „lelkes automatákat”. 233

\footnotetext{
${ }^{233}$ A Spinoza-Kant gondolatmenet kifejtését lásd: KSA 12.260 sk. „Spinoza’s psychologischer Hintergrund. Spärlich!

1) Der hedonistische Gesichtspunkt im Vordergrund Worin besteht die beharrliche Freude oder wie kann der freudige Affekt verewigt werden?

So lange die Freude sich auf etwas Einzelnes bezieht, ist sie beschränkt und vergänglich; sie wird vollkommen, wenn sie nicht mehr mit den Dingen wechselt, sondern in dem wandellosen Zusammenhange ruht; sie ist ewig, wenn ich das All in mein Eigenthum, omnia in mea, verwandle und von diesen omnia mea jeden Augenblick sagen kann »mecum porto« $[\ldots]$
} 
2) der natürlich-egoistische Gesichtspunkt: Tugend und Macht identisch. Sie entsagt nicht, sie begehrt, sie kämpft nicht gegen, sondern für die Natur; sie ist nicht die Vernichtung, sondern die Befriedigung des mächtigsten Affekts. Gut ist, was unsere Macht fördert: böse das Gegentheil. Tugend folgt aus dem Streben nach Selbsterhaltung. »Was wir thun, thun wir, um unsere Macht zu erhalten und zu vermehren«. »Unter Tugend und Macht verstehe ich dasselbe.«

Finis $=$ appetitus. Virtus = potentia. Eth. IV Defin. VII. VIII.

3) der spezifische »Denker« verräth sich. Die Erkenntniß wird Herr über alle anderen Affekte; sie ist stärker. $[\ldots]$

Die antike Philosophie hatte den Menschen als Zweck der Natur im Auge

Die christliche Theologie dachte die Erlösung des Menschen als Zweck der göttlichen Vorsehung.

Merkwürdig Spinoza: »ich verstehe unter conscientiae morsus die Traurigkeit, begleitet von der Vorstellung einer vergangenen Sache, die gegen alles Erwarten ausgefallen ist«. Eth. III Prop. XVIII. Schol. I. II. p. 147. 48. Affect. Def. XVII p. 188. [...]

Spinoza wehrt sich gegen die, welche sagen, Gott wirke alles sub ratione boni. Diese scheinen etwas außerhalb Gottes anzunehmen, das von Gott nicht abhängig ist, worauf er sich wie auf ein Musterbild in seinem Handeln richtet oder wohin er, wie nach einem Ziele trachtet. Das heißt fürwahr Gott dem Schicksale unterwerfen: was die größte Ungereimtheit ist. Eth. 1 Prop. XXXIII Schol. 2. [...]

Psychologischer Fehlschluß: als ob die Dauerhaftigkeit eines Dings die Dauerhaftigkeit der Affektion verbürgte, die ich zu ihm habe!

(vollkommene Abwesenheit des »Künstlers«) Höchste und komische Pedanterie eines Logikers, der seinen Trieb vergöttert

Spinoza glaubt, Alles absolut erkannt zu haben.

Dabei hat er das größte Gefühl von Macht. Der Trieb dazu hat alle anderen Triebe überwältigt und ausgelöscht.

Das Bewußtsein dieser »Erkenntniß« hält bei ihm an: eine Art »Liebe zu Gott« resultirt daraus, eine Freude am Dasein, wie es auch sonst ist, an allem Dasein.

Woher kommen alle Verstimmungen, Trauer, Furcht, Haß, Neid? Aus Einer Quelle: aus unserer Liebe zu den vergänglichen Dingen. Mit dieser Liebe verschwindet auch das ganze Geschlecht jener Begierden. [...]

Das theologische Vorurtheil bei Kant, sein unbewußter Dogmatismus, seine moralistische Perspektive als herrschend, lenkend, befehlend

Das $\pi \rho \tilde{\omega} \tau o v ~ \psi \varepsilon \tilde{\delta} \delta$ o $:$ wie ist die Thatsache der Erkenntniß möglich?

ist die Erkenntniß überhaupt eine Thatsache?

was ist Erkenntniß? Wenn wir nicht wissen, was Erkenntniß ist, können wir unmöglich die Frage beantworten, ob es Erkenntniß giebt. Sehr schön! Aber wenn ich nicht schon »weiß«, ob es Erkenntniß giebt, geben kann, kann ich die Frage »was ist Erkenntniß« gar nicht vernünftigerweise stellen. Kant glaubt an die Thatsache der Erkenntniß: es ist eine Naivetät, was er will: die Erkenntniß der Erkenntniß!

»Erkenntniß ist Urtheil!« Aber Urtheil ist ein Glaube, daß etwas so und so ist! Und nicht Erkenntniß!

»alle Erkenntniß besteht in synthetischen Urtheilen« — eine nothwendige und allgemeingültige Verknüpfung verschiedener Vorstellungen -

mit dem Charakter der Allgemeinheit (die Sache verhält sich in allen Fällen so und nicht anders)

mit dem Charakter der Nothwendigkeit (das Gegentheil der Behauptung kann nie stattfinden)

Die Rechtmäßigkeit im Glauben an die Erkenntniß wird immer vorausgesetzt: so wie die Rechtmäßigkeit im Gefühl des Gewissensurtheils vorausgesetzt wird. Hier ist die moralische Ontologie das herrschende Vorurtheil.

$[\ldots]$

Also: die Frage ist, woher unser Glaube an die Wahrheit solcher Behauptungen seine Gründe nimmt? Nein, woher er seine Urtheile hat! Aber die Entstehung eines Glaubens, einer starken Überzeugung ist ein psychologisches Problem: und eine sehr begrenzte und enge Erfahrung bringt oft einen solchen Glauben zuwege!

Er setzt bereits voraus, daß es nicht nur »data a posteriori« giebt, sondern auch data a priori, »vor der Erfahrung«. Nothwendigkeit und Allgemeinheit können nie durch Erfahrung gegeben werden: womit ist denn nun klar, daß sie ohne Erfahrung überhaupt da sind? [...]

Kant sagt: doch! die mathematischen! Und wenn es also solche Urtheile giebt, giebt es vielleicht auch Metaphysik, eine Erkenntniß der Dinge durch die reine Vernunft! Quaeritur.

Mathematik ist möglich unter Bedingungen, unter denen Metaphysik nie möglich ist

alle menschliche Erkenntniß ist entweder Erfahrung oder Mathematik

Ein Urtheil ist synthetisch: d.h. es verknüpft verschiedene Vorstellungen

es ist a priori: d.h. jene Verknüpfung ist eine allgemeine und nothwendige, die nie durch sinnliche Wahrnehmung, sondern nur durch reine Vernunft gegeben sein kann.

Soll es synthetische Urtheile a priori geben, so wird die Vernunft im Stande sein müssen, zu verknüpfen: das Verknüpfen ist eine Form. Die Vernunft muß formgebende Vermögen besitzen. 
Deleuze Spinoza-interpretációja ${ }^{234}$ tökéletesen plauzibilisnek tünhet a nietzschei filozófia differencia-gondolkodásként történő rekonstrukciójakor. Mi azonban, mint azt a bevezetésben már jeleztük, nem egyszerüen differencia-filozófiaként, hanem a neokantiánus reprezentáció-kritika talajából sarjadó, totális metafizika-kritikaként értelmezzük Nietzsche gondolatait. A differencia-gondolkodás számára kétségtelenül nagy jelentőséggel bír Deleuze gondolatmenete, melynek logikájával, egészen az utolsó előtti lépésig, együtt tudunk haladni. Azonban, mint azt értekezés második részében részletesen is alkalmunk lesz majd kifejteni, a spinozai affektus-tan nietzschei adaptációját számunkra mégsem az önmaga maximumáig, és pontosan addig terjeszkedő cselekvőképesség deleuze-i értelemben vett, immanens önélvezete jelenti. A hatalom akarása elsődlegesen a hatalomban rejlö, önmagára irányuló törekvés, és mint ilyen, az „aktív differencia” önmagából-önmagában való újratermelődésének elve.

\section{4. Az ,aktív differencia” mint genealógia: a morálkritikák}

A Zarathustra „negyedik és egyben utolsó” könyve 1885-ben jelenik meg; Nietzsche nem talál rá kiadót, így saját költségén, minimális példányszámban publikálja. Fájdalmai tovább erősödnek, szinte már teljesen vak, de mégis úgy érzi, magányra vágyik. Már évek óta

Raum und Zeit als Bedingung der Erfahrung. [...]

$<$ Kant $>$ sieht in der Geschichte nichts anderes als eine moralische Bewegung.

$[\ldots]$

Psychologischer Idiotismus

$[\ldots]$

Die Denkbarkeit der Freiheit beruht auf der transscendentalen Ästhetik. Kommen Zeit und Raum den Dingen als solchen zu, so sind die Erscheinungen gleich den Dingen an sich, so ist zwischen beiden keine Erscheinung möglich, so giebt es nichts von der Zeit unabhängiges, so ist die Freiheit schlechterdings unmöglich. Freiheit kann nur gedacht werden als Eigenschaft eines Wesens, das den Bedingungen der Zeit nicht unterliegt, also nicht Erscheinung, nicht Vorstellung, sondern Ding an sich ist.

Warum sind Erscheinungen nicht Dinge an sich? Weil sie in Raum und Zeit sind, und Raum und Zeit reine Anschauungen sind.

Gegen die angebliche psychologische Freiheit sagt Kant: »Wenn unsere Freiheit darin bestände, daß wir durch Vorstellungen getrieben werden, als ein automaton spirituale« so »würde sie im Grunde nicht besser als die Freiheit eines Bratenwenders sein, der auch, wenn er einmal aufgezogen worden, von selbst seine Bewegungen verrichtet.«

Die Freiheit ist undenkbar in der Erscheinungswelt, es sei die äußere oder die innere"

${ }^{234}$ Deleuze Spinoza- és Nietzsche-értelmezésének összefüggéseiről bővebben lásd: Paolo Bolaños: „Nietzsche, Spinoza, and the Ethological Conception of Ethics.” In: Minerva - An Internet Journal of Philosophy, Vol. 11. 2007. Online: http://www.minerva.mic.ul.ie/vol11/Deleuze.html (Zárójelben jegyezzük meg, hogy Bolaños írásából számunkra kizárólag a remekül összegzett hatástörténeti összefüggések bírnak jelentőséggel, a belőlük levont következtetésekkel már nem értünk egyet.) 
gyülnek a Túl jón és rosszon jegyzetei; a mü alcíme: „Egy eljövendő filozófia előjátéka” pedig már minden érték átértékelésének tervére utal. Ahogyan az Ecce homóban írja: miután kimondta a legnagyobb igent, végre elérkezett filozófiája „tagadó, nemetcselekedö"235 "részéhez; de ez természetesen sem az eddig leírtaknak, sem pedig magának az affirmációnak mint elvnek a tagadását nem jelenti. Valóban, a központi probléma továbbra is az emberi civilizáció jövőjének problémája, figyelembe véve a kultúra „elembertelenedésének” és az emberfeletti ember megjósolt eljövetelének ellentétes irányú mozgásait, általánosabban: az életnek és a dècadence-nak, az élettel ellentétes tendenciáknak a morál kritikája kapcsán már körvonalazott szembenállását. ${ }^{236}$

A Túl jón és rosszon a Platón óta a filozófiában uralkodó dogmatizmus és szubjektivizmus kritikája; Nietzsche úgy véli, korának a kereszténység, a „népnek szóló platonizmus" 237 ellen kibontakozó harca az ideális pillanat az említett életellenes gondolkodásmód felszámolására. Beláttuk, hogy az igazság akarása alapvető ösztönünk, de már azt is tudjuk, hogy óvatosnak kell lennünk vele; hiszen még mindig nem tettük fel magunknak a legelemibb kérdést: miért éppen az igazság után kutatunk ilyen megszállottan?

\footnotetext{
${ }^{235} \mathrm{EH}$ 107. o.

${ }^{236}$ Vö. Nietzsche (2008) 160. o. („Levél Jacob Burckhardtnak.” 1886. szept. 22.) Volker Gerhardt tanulmánya lényegretörően összegzi az életet erősítő illetve gyengítő erők említett konfliktusának lényegét. Nietzschénél a moralitás dekadencia-ösztön, életellenes energia, vagy még pontosabban „ellen-természet”, világít rá Gerhardt. A „dekadens” a természetes, eleven élet ellentéte; annak elhasznált, törődött, meggyengült torzképe. Amibe Nietzsche maga is komolyan belegabalyodott, az éppen az immoralitás - mint morálon-kívüliség lehetőségének kérdése. Úgy vélte: a morál elméleti megalapozása képtelenség, a gyakorlatban pedig nyilvánvaló önellentmondáshoz vezet. Gerhardt a nietzschei morálkritika négy, központi momentumát emeli ki. Elöször is, mivel a morális ítéletek ösztön-alapúak, mely ösztönök kivétel nélkül az életösztönre utalnak vissza, mondja Nietzsche, a morál elméleti megalapozása csak akkor lehetne lehetséges, ha az élet elméleti megalapozása lehetséges volna - ez pedig egy, a metafizikán túllépni kívánó gondolkodás számára nonszensz. Maga az ilyen szándék is az élet gyengeségét jelzi; erre a legjobb példa a ressentiment jelensége, melyben a gyengék nevében maga a morál fordul minden ellen, ami eleven és erős. Másodszor, az életnek alapvető karaktere a folyamatos alakulás és változás, és a morál mint olyan épp ennek az alap-intenciónak a tagadását jelenti. A harmadik nietzschei ellenvetés a morális beállítottság belsejében rejlő ellentmondásra utal, miszerint sem elégséges alap, sem elégséges ok nem létezik, melyből a morál származhatna, ezáltal pedig épp saját legalapvetőbb követelményének nem képes megfelelni. A morál tehát absztrakció, története pedig az „igazságéval” párhuzamos. Végül, a morális parancsok épp arra az entitásra nem érvényesek, amelyen az egész emberi tudatosság alapul: tudniillik az individuumra magára. A „szabad szellem” pont az általában vett parancs kötelme alól, és az önálló döntésre válik szabaddá. Gerhardt szerint voltak és lesznek is „morális” problémáink - ezen a nietzschei kritika mit sem változtat. A moralitás mint olyan az emberi élet önmeghatározásának szerves része, az élet egyfajta kifejeződése, és ilyenként kell, hogy meghatározza magát, nem pedig az élettel ellentétes irányban. Szigorúan véve, mondja Gerhardt, nem hogy az ész kanti „tényéröl”, de még a tudat „tényéröl” sem beszélhetünk, hiszen sem az ész, sem a tudat nem tartozik a „tények” közé. Az egyetlen „tény”, amelyröl a moralitás vonatkozásában beszélhetünk, az moralitásra való igényünk ténye. Gerhardt számunkra igen meggyőző értelmezésében tehát a nietzschei morálkritika voltaképpen a kanti etikában kulmináló szubsztancialista morálfilozófia kritikája. Nietzsche számára az egyedüli, a voltaképpeni „erény” az „eleven önmagunkravonatkozás", a bátor, distanciált önreflexió. Vö: Volker Gerhardt: Die Moral des Immoralismus. Nietzsches Beitrag zu einer grundlegung der Ethik.” In: Krisis der Metaphysik. Ed. Günter Abel, Jörg Salaquarda. De Gruyter, New-York-Berlin, 1989. s. 417-447.

${ }^{237}$ JR Elöszó.
} 
Miért nem az igazságtalanság az úr? Honnan vesszük egyáltalán, hogy létezik az abszolút értelemben vett ellentét értékeink között? Mi van akkor, ha a „Jó” és a „Rossz” egylényegüek? - Nietzsche a „,veszedelmes talán filozófusait” keresi. ${ }^{238}$ Bármifajta gondolkodás (így a filozófusoké is) először is előnyben-részesítés, mégpedig a létfenntartás ösztöne által vezérelve; ne higgyük tehát, hogy az egésznek bármi köze is van az igazságossághoz vagy az objektivitáshoz. Az ,intellektuális lelkiismeret” azonban valami egészen mást diktál: váljunk kísérletekké, tegyük kockára elöítéleteinket, merjünk „Igazság” nélkül élni! Valljuk be: az igazság akarása nem más, mint a hatalom akarása, vagyis végső soron maga az élet. A félreértés okozója a grammatika; mikor ugyanis azt mondom: „Én akarom”, az „Én”-ben egy egységes, oszthatatlan szubjektumot tételezek a cselekvés alanyaként, holott nincs semmi, ami egy ilyen harmonia praestabilita kohézióját biztosítaná. Épp ezért nem csak a megismerés, de az akarás sem eredendően egységes, az „Én” koherenciája csak látszólagos. ${ }^{239}$ Vegyük észre: Nietzsche sosem magát az igazságot, a morált vagy éppen a hitet tagadta, hanem azoknak a metafizikus-keresztény világrend által kanonizált fogalomrendszerét és alkalmazását. Az élet mozgatórugója az akarat, az akarás pedig igenis morális jelenség, de ,a morálon az azokról az uralmi viszonyokról szóló tanítást értve, amelyek közt az »élet« nevü jelenség keletkezik”. ${ }^{240}$ Nincs egységes akarat, és nincs egységes értelem, csak szükségszerü újra- és újra-értékelés, folyamatos változás, állandó hatalomakarás, ezer és egy interpretáció létezik. Nietzsche „fizio-pszichológiája”241 a morálon túlra merészkedik, hogy ott találja meg téves értékeléseink, egész, hazugságokon alapuló világrendünk gyökereit, hogy feltárja az akarat genealógiáját. A pszichológia tehát az objektív megismerést, utóbbin a szokás biztosította egységet és általánosságot; az akarat és az élet gyengeségét értve.

Természetesen nem mindenki képes kilépni az elöítéleteknek ebből az évezredek óta müködő, biztonságossá öregedett világából; de csak a „hetednapi magányt” választók számára adatik meg a teremtés joga, csak a szabaddá vált szellem képes kimondani az első, ártatlan

\footnotetext{
${ }^{238}$ Ld. JR 2. §, de erre utal már a „,vita femina” kinyilvánítása is az „Előszó” első mondatában; az igazság női természetének hangsúlyozása rögtön a probléma elevenébe vág: mi történik, ha minden dichotómiában (valóságlátszat, igazság-hazugság, Jó-Rossz, férfi-nő) az eddig alulértékelt fél kerül hatalomra? Ha az igazság nö, akkor nőként is viselkedik: kacér, tünékeny és hazug, hiteget és azután otthagy. Nietzsche „igazsága”, az Élet, az egyetlen örökkévaló pedig minden bizonnyal ilyen.

${ }^{239}$ Vö. JR 17.§ Itt Nietzsche ismét a „grammatika csábításáról” beszél, ahogyan már A nem-morálisan felfogott igazságról és hazugságról idején is tette, még 1873-ban. Nem lehet eléggé hangsúlyozni e bűn súlyát: a nyelvhasználat az oka, hogy kauzálisan (rendszerben) gondolkodunk, és hogy minden cselekvéshez cselekvőt rendelünk. Circulus vitiosus...

${ }^{240}$ JR $19 . \S$

${ }^{241}$ JR 23. §
} 
igent, miután az elavult értékekre nemet mondott. Ez a fajta szabadság azonban csak azoknak jár, akik elég erősek ahhoz, hogy ne vágyjanak együtt-érzésre, és ne érezzenek részvétet; ugyanis ők azok, akik „beérik” saját perspektívájukkal, mert tudják, hogy az az egyedül számukra-való. Azok, akiket Nietzsche megszólít, tudják, hogy az igazság és az élet is perspektivikus, a perspektíva pedig választás függvénye. Ha valaki mélyen az Élet szemébe néz, ahogyan Zarathustra tette, az valami ,alapja-nincsbe” süllyed: az erős, vakmerő és szabad emberek Isten halála után élvezik a régi-új feltétel-nélküliséget; a rabszolgajellemeknek viszont szükségük van valami feltétlen, abszolút érvényüre, mint létezésük alapfeltételére. Nietzsche úgy véli, az Egy iránti igény barbárság, így az egy Isten szeretete is az; már csak azért is, mert minden más lehetőséget kizár. ${ }^{242}$ Ahogyan pedig mindez szokássá, gyakorlattá - mondjuk ki: rítussá - válik, eluralkodik rajtunk a „ritmus zsarnoksága”, és elfelejtjük, hogy a cselekvésünk alapjául szolgáló értékítélet egy alapvetően szubjektív és szituatív érzetet tükröz. Az emberi értéktételezéssel kapcsolatos összes „pszichológiai” megfigyelése, melyeket a „szabad szellem trilógiában” ismertet, a szokás és a félelem uralmát ismeri fel több évezredes emberi történelmünk legfontosabb eseményeinek hátterében. Amit tehát a Nietzsche-féle szelekciós gondolat követel, az a félelem és hazugság konformista csorda-moráljának $^{243}$ felszámolása, és az értékek átértékelésére képes - tehát önmagát a túlhaladás értelmében megsemmisíteni képes - emberfeletti ember eljövetele. Nietzsche Übermensche mindennek ura, de mindenekelőtt - Önmagának: szellemének és érzékeinek, értékeinek és ítéleteinek, gyönyöreinek és fájdalmainak. Számára a megismerés mindig birtokba-vétel, számomra-valóvá-tétel; az átformálás viszont mindig rombolással jár, a teremtés tehát szükségszerüen kegyetlen. ${ }^{244}$ Az előkelő embert az „,́zlés kegyetlensége”, más

\footnotetext{
${ }^{242}$ Nietzsche 1884 nyarán-őszén a Zarathustra utolsó részén dolgozik, mikor így emlékezik: „tizenkét esztendős koromban kitaláltam egy fura szentháromságot: úgymint az atyaistent, a fiúistent meg az ördög-istent. Úgy okoskodtam, hogy isten önmagát elgondolván alkotta meg az istenség második személyét: csakhogy saját ellentétét is muszáj volt elgondolnia, tehát megalkotnia, hogy elgondolhassa önmagát. - Ez volt filozofálásom kezdete." ÚF F35/26[390] ( KSA 11.253)

${ }^{243} \mathrm{Az}$,úr-morál” a teremtést, míg a „rabszolga-morál” a hasznosságot tekinti alapvetőnek - míg előbbiek egoizmusa a vele egyenrangúak tiszteletén, utóbbiaké a felettük állókkal szembeni gyülöleten és irigységen alapul.

${ }^{244}$ Leo Strauss értelmezésében a Túl jón és rosszon Nietzsche leginkább „platonizáló” írása; Strauss, Heideggerhez hasonlóan, egyfajta „kifordított platonizmusként” értelmezi Nietzschét. Egy rövid példa: a hatalom akarása, mint mondja, a magánvaló Jóra irányuló eros helyét foglalja el, de ezzel egy időben a „tiszta szellemét" is; ezért lesz a filozofálás a hatalomakarás legszellemibb módja. A hatalom akarása ekkor törvényt ad a természetnek, és nem borul le semmilyen önmagában való igazság elött; tehát míg a platóni „tiszta szellem” megragadja, a nietzschei hatalomakarás megteremti az igazságot. (Vö. Leo Strauss: „Note on the Plan of Nietzsche's Beyond Good and Evil." In: Interpretation: A Journal of Political Philosophy. 1973/2-3., pp. 188205. Nietzsche és a platonizmus viszonyának tekintetében Robert B. Pippin arra hívja fel a figyelmet, hogy Nietzsche Platónhoz hasonlóan úgy gondolta, az igazság akarása egyfajta szerelmi vágy; és megállapítja: a filozófusok eléggé ,„ügyetlen szeretők”. De ami ennél lényegesebb, hogy ezzel Nietzsche nem a modern értelemben, a tudatlanságtól való szenvedésként értelmezi az igazság iránti vágyakozást, hanem ellenkezőleg: nagyon is pozitív módon, egy jobb élet lehetőségének vágyaként. Azonban míg Diotima a Lakomában a Szépet
} 
szóval a „nemet-cselekvés” képessége jellemzi, az arisztokratikus társadalmat pedig a „distancia pátosza”hatja át, mely akarat és akarat közé feszülve fenntartja a folyamatos önmeghaladás mozgását: az „aktív különbséget”.

A Túl jón és rosszon azokhoz szól, akik Nietzschéhez hasonlóan gyanakvással szemlélik a modern kultúrát; azokhoz, akik úgy érzik, az erkölcsi világrend felszíni rendezettsége alatt valami titok lappang. Az ilyen emberek egyébként mindenre gyanakodva tekintenek, ami túlságosan egyértelmünek tünik, hiszen jól tudják: nincs magánvaló lényeg vagy egységes értelem. Ez a „gyanú iskolája”, melyet az Emberi - túlságosan is emberi 1886os Előszava is említ. ${ }^{245}$ Nietzsche valójában már a kezdetektől genealógusként gondolkodik, de majd csak A morál genealógiájában végzi el az erkölcsi világrend konzekvens és koncepciózus destrukciójának munkáját. A „gyanús” prekoncepciók összegyüjtése és leleplezése azonban - és ez Nietzsche munkájának másik jellegzetessége - a pszichológus nézőpontjából történik. Az ember legelső tevékenysége, „legelbizakodottabb pillanatában”, az értéktételezés volt, ${ }^{246}$ ezért vált az igazság utáni kutatás „legemberibb” ösztönünkké. Nietzsche azonban tagadja a magánvaló lényeg és az metafizikai Igazság létezését, ehelyett plurális és metaforikus igazságról és perspektivikus gondolkodásról beszél, mert úgy gondolja: az igazság akarása azt kell, hogy jelentse, hogy képesek vagyunk saját igazságot teremteni. A ,jövő filozófusának” feladata tehát az értékek értéke utáni genealógiai kutatás, mely végül egyszersmind pszichológiaivá válik, mégpedig azon a ponton, ahol az értéktételezés ösztönként lepleződik le. Ezért nem érhet véget a „feladat” a rombolással: hiszen szükségünk van az új értékekre. ${ }^{247}$ A Túl jón és rosszonban Nietzsche voltaképpen annak lehetôségét veti fel, hogy mi van akkor, ha a mindezidáig legfőbb értékként elfogadott „,igazság” nem is létezik? Hiszen ha nem létezik a dolgok magánvaló lényege, az igazság is csak metaforikus, tehát plurális és változékony lehet - az ,igazság” Nietzschénél már azóta „gyanús” fogalom, mióta, még az Emberi - túlságosan emberiben, morális eredetűnek

(Jót) nem testi, hanem kizárólag ideális valójában szerethetjük, kizárólag ez garantálja vágyunk beteljesülését, addig a hatalom akarása a par excellence ösztön. A ,jövő” minden értéket a hatalomakarás perspketívájából átértékelő filozófiája ilyen körülmények között bajosan lehetne egyfajta „kifordított platonizmus”... (Vö. Robert B. Pippin: „Morality as Psychology, Psychology as Morality: Nietzsche, Eros, and Clumsy Lovers.” In: Nietzsche's Post-Moralism.Essays on Nietzsche's Prelude to Philosophy's Future. Ed. Richard Schacht. Cambridge, UP, 2001, pp. 87-91.

${ }^{245}$ Vö. EE Elöljáró beszéd. 1.§; illetve KSA 2.13 „Was dazu reizt, auf alle Philosophen halb misstrauisch, halb spöttisch zu blicken, ist nicht, dass man wieder und wieder dahinter kommt, wie unschuldig sie sind - wie oft und wie leicht sie sich vergreifen und verirren, kurz ihre Kinderei und Kindlichkeit - sondern dass es bei ihnen nicht redlich genug zugeht: während sie allesammt einen grossen und tugendhaften Lärm machen, sobald das Problem der Wahrhaftigkeit auch nur von ferne angerührt wird."

${ }^{246}$ Vö. NMIH 3. o.

${ }^{247}$ Vö. Rolf-Peter Horstmann: „Nietzsche: Beyond Good and Evil.” In: Introductions to Nietzsche. Ed. Robert R. Pippin. Cambridge UP, Cambridge, 2002. pp. 178-188. 
bizonyult (sőt, ha visszatekintünk, már $A$ tragédia születésében, és a hagyatékban maradt $A$ nem-morálisan fölfogott igazságról és hazugságról szóló rövid írásban is erröl van szó). Ha azonban az ,igazság” értéke megkérdőjeleződött, akkor nem kell-e visszahelyeznünk jogaiba a „tévedést” mint olyat? A ,veszedelmes talán” annak lehetősége, hogy az ,igazság” mindig is a „tévedésből” származik, hogy ,az, ami azoknak a jó és tisztelt dolgoknak az értékét adja, éppen abban áll, hogy ezekkel a bajos, látszólag ellentétes dolgokkal veszedelmes rokoni kapcsolatban, összeköttetésben állnak, egymásba vannak horgolva, tán még egy-lényegüek is." 248

Nietzsche filozófiája ekkorra (1886-ot írunk) minden részletében a hatalom akarásának koncepciója köré húzódott, és szinte kivehető koncentrikus körökben gyürüzik körülötte feladata immár egyértelmü: minden érték átértékelése. Időközben tárgyal Fritzsch-csel könyvei újrakiadásáról; ekkor készül el $A$ vidám tudomány ötödik könyve, valamint a korábban már említett kései Előszók $A$ tragédia-születéséhez, illetve a „szabad szellemtrilógia" darabjaihoz. Utóbbiakról később azt írja Meta von Salisnak, hogy ezekben voltaképpen saját fejlődéstörténetét (az „Önkritika-kísérlettől” egészen a Genealógia előszaváig) kommentálja. ${ }^{249} A$ morál genealógiája „egy pszichológus három alapvető előmunkálata" minden érték átértékeléséhez; ${ }^{250}$ az Emberi - túlságosan is emberi folytatásának tekinthető, amennyiben konkretizálja és összegzi a morális előítéletek eredete utáni kutatás eredményeit. Ezek mélyére ásva egyetlen, meghatározó oppozíciót talál: az egészként értett „Egy” és az „egyedi” ellentétét - előbbi kizárólag „,tömege” révén válik meghatározóvá, míg utóbbi saját ereje révén; ez a rabszolgák és az urak erkölcse közti alapvető különbség. Nietzsche alapjában véve az előző morálkritikában feltett kérdést ismétli meg: mi történne, ha mindennek az ellenkezőjét fogadnánk el igaznak - mi lenne, ha minden bevett értéket felváltana a vele ellentétes? Nietzsche nem immorális, de nem is amorális. Amit

\footnotetext{
${ }^{248}$ JR 2. §, ld. továbbá JR 3., 10., 12. (Nietzsche itt Boscovichra hivatkozik, „aki a lengyel Kopernikusszal együtt, a látszat eleddig legnagyobb és leggyőzelmesebb ellenfele volt”), 24., 34., 54. (Kant-kritika!) 134., 190., 229. §

${ }^{249}$ Vö. BVN-1887,908. „Brief an Meta von Salis.” („Mein Druck ist beim letzten Drittel angelangt; das Buch wird heißen »Zur Genealogie der Moral«. Eine Streitschrift". Damit ist nunmehr alles Wesentliche angedeutet, was zur vorläufigen Orientierung über mich dienen kann: von der Vorrede zur Geburt der Tragödie bis zur Vorrede des letzt genannten Buchs - das giebt eine Art "Entwicklungsgeschichte«. Nichts ist übrigens degoutanter, als sich selbst commentieren zu müssen; aber bei der vollkommnen Aussichtslosigkeit dafür, daß irgend jemand Anders mir dies Geschäft hätte abnehmen können, habe ich die Zähne zusammengebissen und gute Miene, hoffentlich auch »gutes Spiel« gemacht. Die Arbeit eines ganzen Jahrs! [eingerechnet das fünfte Buch der gaya scienza, das ich besonders empfehle]") Meta nem mellesleg harcos feminista, az első svájci nő, aki doktorátust szerzett. Nietzsche 1884-ben ismerte meg Zürichben, innentől kezdve egészen 1889-ig leveleztek.

${ }^{250}$ Vö. EH 110. o.
} 
ő akar, az egy „ellen-eszmény” felmutatása: egy morálon-túli világ felfedezése, ahogyan annak idején elképzelte; a belső világ tengerein kalandozva. ${ }^{251}$

A Genealógia első értekezése a kereszténység lélektanát tárja fel a morális értékbecslés két alapvető, egymással ellentétes típusából kiindulva. Az „úr-morál” és a „rabszolgamorál” ellentétét itt az egoista és egalitárius értékelésmód közti eltérés szemlélteti: a tömegek morálját a csordaösztön és a hasznosság utilitarista eszménye kovácsolja egységgé; a nemesek erkölcsét viszont a különbözés, a „distancia pátosza” tagolja hierarchiává, melyben a közönséges/hitvány, illetve a harcos/nemes (lat. malus vs. bonus) különbsége adja a további értékmérés alapját. A „distancia pátosza” a „szabad szellem” pozícióját jellemzi, aki képes az önmagától és másoktól való perspektívateremtő eltávolodásra. Ezért fontos ismételten hangsúlyozni a nietzscheinek a „,különbség” korábbi, metafizikai koncepcióitól való radikális eltérését. Erre a célra különösen alkalmas a totalizációs folyamat abszolút negatív aspektusaként értett hegeli differencia-terminus, melyszempontunkból a nietzschei aktív, operatív különbség radikális ellenpontjának tekinthető. Hegelnél az „úr” és a „,szolga” az öntudat két pólusa, önmagától való elidegenedése következtében történő polarizációjának eredményei. Az öntudat tehát ,én”-re és „nem-én”-re osztja saját magát, így azonban egy úrszolga szembenállást hoz létre önmagán belül. A szellem abszolutizációjának, azaz önmagához való visszatérésének záloga tehát ezen ellentmondás megszüntetése, ugyanakkor az önreflexiónak ebben a felosztottság révén adódó momentumában az ellentétek mégis megőrződnek. Míg Hegelnél a differencia és az egyenlőtlenség végül az abszolút egység, az abszolút indifferencia egység-formájában békülnek ki, vagyis az ellentétek dialektikus egymásba-folyása végül egységet eredményez, addig Nietzsche a különbséget tekinti eredetinek, a különbözők közötti viszonyokat és azok hierarchiáját. Nietzschénél a negatív csak az affirmáció lényegi agresszivitása, melyben az akarat saját különbözőségére mond igent. ${ }^{252}$ Az előkelő embert az erő és a cselekvés aktivitása hatja át, a szolgát viszont a bosszú szelleme hajtja, ez a végletesen passzív és reaktív erő, melyet az ellentmondás vágya hajt; ez a tehetetlenségérzetből táplálkozó bosszúvágy a nietzschei ressentiment. Ennek erősebb, és sokkal veszélyesebb formája a papi morál, ez ugyanis, látszólagos ártatlansága dacára, már

\footnotetext{
${ }^{251}$ Vö. u. ott, illetve H $575 . \S$ „De hát hova törekszünk? Tán át akarunk repülni a tengeren? Hová ragad bennünket ez az ellenállhatatlan vágyódás, amely bármilyen örömnél nagyobb becsben áll a szemünkben? Miért éppen ebbe az irányba, oda, ahol eddig az emberiség minden napja lenyugodott? Egyszer tán bennünket is megszólnak majd, hogy mi is, nyugat felé hajózva, Indiát reméltük elérni, - ám az volt a végzetünk, hogy a végtelenen fussunk zátonyra? Vagy pedig, testvéreim? Vagy pedig?"

${ }^{252}$ Vö. Douglas Burnham: Reading Nietzsche. An Analysis of ,,Beyond Good and Evil”. Acumen Publishing Ltd, Stocksfield, 2007, pp.77-78. Bövebben itt: Robert R. Williams: Tragedy, Recognition, and the Death of God. Studies in Hegel and Nietzsche. Oxford, UP, 2012, pp. 33-53.
} 
nem csak tagadni, hanem - éppen szellemisége révén - teremteni is képes, méghozzá az erősek értékeivel ellentétes reaktív értékeket. ${ }^{253} \mathrm{Az}$ erős önmagára mond igent, a gyenge pedig a tőle különbözőre nemet. Az erős mégis képes akár önmagát is elfelejteni, hogy aztán túlléphessen saját magán is, mert tudja, hogy egyedül az erő és annak müködése fontos. „Nincs »lét« a tett, hatás, létrejövés mögött; a »tettest« csupán hozzáköltik a tetthez - ismétli magát Nietzsche -, a tett minden.,254

A kereszténység lélektanát az egyes ember pszichológiájából érthetjük meg. De vajon hogy müködik az ember? Miért van az, hogy gyengeségében nem képes sem a múlttal, sem a jövővel megbirkózni? Nietzsche szerint a kulcs a ,jó emésztés”, vagyis az emlékezés és felejtés újfajta egyensúlya: az eddig megszokottnak éppen a fordítottját kell tennünk: a múltat kell elfelejtenünk, a jövőre pedig emlékeznünk. A felejtés teszi ugyanis lehetővé, hogy megszabaduljunk a múlt terheitől, hogy legyen jelenünk, az emlékezésre pedig elsősorban az ígérés képességének van szüksége: ez az „akarat tulajdonképpeni emlékezete”. ${ }^{255}$ A rossz lelkiismeret, más néven büntudat hátterében a „bün” fogalmának etimológiája áll: a bün [Schuld] szó eredete ugyanis az adósság [Schulden], tehát a bűn eleve valami olyasmi, ami egyenértékü büntetéssel kiegyenlíthető, azaz jóvátehető. A moralitás kezdeteinél ember és ember mint hitelező és adós áll szemben egymással, a csere terminusaiban történő értékelés pedig mindent azonosíthatóvá, objektívvé tesz. A többség megalkotta az Igazságot, a szokás hatalma pedig idővel kialakította a moralitást; ez az erkölcsi világrend rövid története. Egy ilyen gondolkodásmód nem más, mint a szerves, eleven élet törvényeinek tagadása; a természetben minden fejlődés túl-haladás, melyben az erősebb akarat leigázza a gyengébbet. Azonban amint az életösztönök bủnné válnak, és többé már nem élhetjük ki öket, de ösztönök lévén lényünk szerves részét alkotják, befelé fordulnak, és az ember önmaga ellenségévé válik; ez a „rossz lelkiismeret” eredete. A „eredendő bűn” a kitörni vágyó akaraté, a saját igazság akarásáé; rettentő súlyától csak a nemet-mondás szabadíthat meg: az ateizmus, Isten tagadása így lesz egyfajta „második ártatlanság”. ${ }^{256}$

A kereszténység tehát valóban a gyengék vallása; azoké, akiket meg lehet védelmezni önmaguktól. Az aszketikus eljárások révén az életösztön természetes kegyetlenségeinteriorizálódik, az emberben pedig önmaga ellen fordul, így lesz az aszketikus

${ }^{253}$... és ezzel megkezdődik a „morál területén végbemenő rabszolgafelkelés”. (Vö. MG I:10.§)

${ }^{254}$ MG I:13.§, illetve vö. JR 277.§ - Elég baj! Megint a régi történet! Mikor az ember már készre építette a házát, jön csak rá, hogy megtanult közben észrevétlenül valamit, amit éppenséggel tudnia kellett volna, mielőtt építkezni - kezdett. Az örök, átkos »Késő!« - Minden késznek a melankóliája!...” (kiemelés tőlem, L. E.) ${ }^{255}$ Vö. MG II: $1 . \S$

${ }^{256}$ Vö. MG II:20.§ 
ideál a hatalomakarás szöges ellentéte: a semmi akarása. A három legfontosabb követelmény: a szegénység, az alázat és a szüziesség életellenes értékek, azonban a szenvedéstől kétségtelenül megszabadítanak. Ha ugyanis a Semmit akarjuk, ${ }^{257}$ csak akkor van meg mindenünk, ha semmink sincs, és így elveszíteni sem tudunk semmit; ez logikus. Épp ezért tartja Nietzsche az aszketikus ideált a lehető legszellemibb bosszúnak - tudniillik magával az élettel szemben. Hiszen a szenvedés ugyanolyan szervesen tartozik az élethez, mint a gyönyör, így tagadásával az életre is nemet mondunk. Simon May tézise szerint a Genealógiában válik világossá az amor fati elvének valódi jelentése. Bebizonyosodik ugyanis, hogy a szenvedés igenlésének szükségessége nem igazolható, amennyiben el akarjuk kerülni a teodicea gyanúját. Nietzsche legfőbb törekvése, hogy rátaláljon egy olyan élethez való hozzáállásra, amely igenli a szenvedést - és ez az igenlés éppen maximális irracionalitásából nyeri valódi mélységét - és végső könnyedségét. ${ }^{258}$ A ,jövő filozófusa" ezzel szemben közömbös, gúnyos és erőszakos: kalapáccsal filozofál és könnyen felejt. A felejtés, mint láttuk, távolról sem puszta reakció; épp ellenkezőleg: aktív gátlóképesség; nem tagadás, hanem elutasítás, melynek révén megszabadulunk a szenvedést okozó dolgoktól. Ám a felejtés túlhatalmát sem engedhetjük meg; az emlékezetben ezért épp ellenkezőleg, már eleve csak az marad meg, ami valamilyen módon fájdalmat okoz, belénk ég. Nietzsche már a „Szabad szellem trilógiában” is elmondta: nincsenek tiszta, erkölcsi ítéletek, mert minden döntésünk alapja egy fiziológiai ingerre adott fiziológiai reakció; a reflexió, az általánosítás, a kauzális gondolkodás és a szabad akarat eszméje csak eztán jön. Nietzsche „,beteg állatnak” nevezi az embert, hiszen kétszeresen szenved: először magától a fájdalom fizikai érzésétől, azután ezen fájdalom tudatától. Úgy tűnik, maga az interiorizáció, a belsővé-tudatossá tétel az emberiség legfőbb tünete; a ,jövő filozófusa” pedig az emberiség orvosa lehet, amennyiben képes lesz rá, hogy megtanítson bennünket - felejteni. ${ }^{259}$

Nietzschét a Genealógia kapcsán sokszor vádolják rejtett platonizmussal, mondván: az eredet utáni kutatás voltaképpen a dolgok tiszta, idealisztikus lényegének feltárására irányul. A genealógiai módszer azonban épp a platonizmus alapvető tévedésének leleplezését célozza: annak igazolását, hogy a világnak nincsen rejtett eredete, mely azután viszonyítási pontként

\footnotetext{
${ }^{257}$ Vö. MG III:1.§ „Ám abban, hogy az aszketikus eszmény egyáltalában ilyen sokat jelentett az ember számára, az emberi akarat alapvetö tényszerüsége, az emberi horror vacui jut kifejezésre: az embernek célra van szüksége, - és inkább akarja a Semmit, mintsem hogy semmit se akarjon."

${ }^{258}$ Vö. Simon May: „Why Nietzsche is still in the morality game.” In: On the Genealogy of Morality. A Critical Guide. Ed. Simon May. Cambridge, UP, 2011. pp. 78-100.

${ }^{259}$ A „belső” és „külső” fájdalom megkülönböztetéséröl, illetve a filozófus „hippokratészi” feladatáról lásd bővebben: Arthur C. Danto: „Some Remarks on The Genealogy of Morals.” In: Nietzsche, Genealogy, Morality Essays On Nietzsche's „On The Genealogy of Morals”. Ed. Richard Schacht. California UP, Berkley, 1994, pp. $35-48$.
} 
szolgálhatna az egész megismeréséhez. Nietzschére jellemző módon itt is a roppant tudatos terminológia-használat ${ }^{260}$ siet segítségünkre. A genealógia Nietzschénél a származás [Herkunft], és nem az eredet [Ursprung] kutatása, ${ }^{261}$ mondja Foucault, mert lényege szerint tagadja a dolgok időtlen, tökéletes és igaz lényegének létezését. Az emberi történelem a véletlenszerü események hálózatából szövött, folyamatos alakulásban lévő „test”, melyben minden változás egy erőnek egy másik felett aratott győzelmét jelzi. Az eredet az abszolút nemlétből az abszolút létbe való végzetszerü átmenet, míg a származás egyedüli szabálya a véletlen. A genealógus az erőviszonyok alapjául szolgáló távolságokat, azaz különbségeket vizsgálja, melyből az adott erők hatóképességüket nyerik; a történelem „eseményét” figyeli. Ez a fajta megismerés mindig perspektivikus, hiszen nézőpontja a történelemmel együtt halad, tehát lerombolja a ,jelen”, a „valóság”, az ,azonosság” és az „,igazság” mítoszát. A genealógia mint megismerési mód így végül a szubjektum destrukciójához, az „Én összetevőinek szétválasztásához" - tehát az objektív megismerés és az igazságosság mítoszainak megdöntéséhez vezet. ${ }^{262}$ Foucault-hoz nagyon hasonlóan érvel Eric Blondel. Azt mondja ugyanis, hogy a nietzschei genealógia kapcsán kétféleképpen merülhet fel az eredet kérdése: 1. a történeti, vagy még inkább történelem-elötti problémájaként, mint az abszolút kezdet utáni kutatás; azonban a genealógiai, mint a „test életének nyelve”, nem az őselv, hanem a genezis, a leszármazás feltárását célozza, méghozzá az eleven és mulandó élet talaján. 2. Egy titkos, rejtett alap létezésének gyanúja, amennyiben a morális viselkedést „,tünetként” kezeljük. A genealógia etimológia és szimptomatológia; a genealógus pedig

\footnotetext{
${ }^{260}$ Nietzsche azon szerzők egyike, akiknél semmi sem véletlen, hangozzék ez bármily paradox módon az amor fati filozófusa kapcsán. Azt, hogy szóhasználata, fogalmazásmódja milyen mértékben tudatos, sejthetjük abból az 1876-ból származó tizenkét jegyzettöredékből, melyekben a különböző német igeidők, mondatszerkezetek és ragozások használatáról, lehetőségeiről értekezik. (Ld. KSA 8.282 sk.)

${ }^{261}$ Bár a két kifejezést a német nyelvben általában rokonértelműnek tekintik, Nietzsche kései írásaiban már tudatosan kihasználja a jelentésárnyalatok különbözőségét; erről a hátrahagyott töredékekből is meggyőződhetünk, lásd például $A$ hatalom akarásának utolsó fennmaradt tervezetét 1888 augusztusából, melynek második könyve „Az értékek származása” [Herkunft der Werthe] címet kapta volna (KSA 12.246); illetve a következö helyeket: KSA 11.430 („Die Gesetzgeber der Zukunft. 1. Die Herkunft. 2. Der gebundenste Geist. 3. Die grosse Loslösung. 4. Das Leiden am Menschen. 5. Der neue Wille. 6. Der Hammer.”); 11.616 („Der ersten Spur philosophischen Nachdenkens, der ich, bei einem Überblick meines Lebens, habhaft werden kann, begegne ich in einer kleinen Niederschrift aus meinem 13. Lebensjahre: dieselbe enthält einen Einfall über den Ursprung des Bösen. Meine Voraussetzung war, daß für einen Gott Etwas denken und Etwas schaffen Eins und Dasselbe sei. Nun schloß ich so: Gott hat sich selbst gedacht, damals als er die zweite Person der Gottheit schuf: um aber sich selber denken zu können mußte er erst seinen Gegensatz denken. Der Teufel hatte also in meiner Vorstellung ein ebensolches Alter wie der Sohn Gottes, sogar einen klareren Ursprung — und dieselbe Herkunft. Über die Frage, ob es einem Gott möglich sei seinen Gegensatz zu denken, half ich mir damit hinweg, zu sagen: ihm ist aber Alles möglich. Und zweitens: daß er es gethan hat, ist eine Thatsache, falls die Existenz eines Gott-Wesens Thatsache ist, folglich war es ihm auch möglich -”); 11.652 („Die Herkunft. Was ist vornehm? Die Entstehung des Adels. Die nachahmenden Talente wie Voltaire. Die große Loslösung. Die sieben Einsamkeiten. Der Wille zur Macht.”).

${ }^{262}$ Vö. Michel Foucault: „Nietzsche, a genealógia és a történelem.” In: U. ő: A fantasztikus könyvtár. PallasAttraktor, Bp., 1998, 75-90. o.
} 
egyszerre orvos és filológus. A genealógia az embert szervezetként [Leib], azaz szellem [Geist] és fizikai test [Körper] eredeti és heterogén egységeként kezeli, annak a folyamatnak a rekonstrukciójára törekszik, melynek során ez az eredeti egység test és lélek/szellem dualizmusává deformálódik - röviden: a morál történetének rekonstrukciójára. ${ }^{263}$ Nietzsche a Túl jón és rosszon ötödik könyvében tehát a morál „természetrajzát” [Naturgeschichte] vázolja fel. A „természetrajz” voltaképpen történeti tipológia; a Genealógia pedig a „morál típustana”, ${ }^{264}$ hiszen a morál úgynevezett „tudománya”, az „etikai objektivizmus” nem lehetséges - épp a moralitás esetében szó sincs semmilyen objektivitásról. Sőt mi több, a genealógia voltaképpen csak előkészítője a tulajdonképpeni kritikának: egyrészt anyaggyűjtés- és rendszerezés, illetve a moralitás különböző típusainak szisztematikus leírása, másrészt pedig az egyes értékrendek kialakulásának és fejlődésének vizsgálata. Miután Nietzsche feltárta erkölcsi értékrendünk „,szégyenletes [ti. érzéki, L. E.] eredetét”265 , rátért a kíméletlen kritikára, mely azon túl, hogy rombol, teremt is, méghozzá az értékek átértékelése révén. ${ }^{266} \mathrm{~A}$ morálkritikai müvek tehát mind tartalmi, mind módszertani szempontból az átértékelést előkészítő, valóban „nemet-cselekvő” írások.

A morál genealógiájának megírása minden bizonnyal Nietzsche egyik legzseniálisabb ötlete volt. Hiszen mit is tesz a genealógus? Valamely dolog származását kutatja, lépésröllépésre halad visszafelé, mintha egy épületet bontana, míg végül eljut az alapokig. A Genealógiában Nietzsche az erkölcsi világrend épületét rombolja le: a bontás ugyanis ez esetben megsemmisítés, hiszen amit az alapoknál talál, az nem más, mint csalás, méghozzá a legnagyobb, amit az emberiség története során valaha is elkövethettek. De ezt a csalást éppen mi követtük el saját magunk ellen: a végességtől való rettegésünkben Istent, túlvilágot, Igazságot hazudtunk magunknak. De mint minden csalás, ez is elrejt valamit - hiszen miért csalnánk, ha nincs titkolnivalónk. Nietzsche pedig rájött arra, hogy itt valóban a valaha volt legnagyobb hazugság lepleződött le. Hiszen mi is az „eredendő bün”, ami önmagunk és evilágunk megtagadására kényszerít minket? Nem más, mint az „igazság akarása” - az igazság az, amit minden áron el akartunk rejteni magunk elől. És mi az igazság? - hogy nincs

\footnotetext{
${ }^{263}$ Ld. Eric Blondel: „The Question of Genealogy.” In: Nietzsche, Genealogy, Morality. Essays On Nietzsche's „On The Genealogy of Morals”. Ed. Richard Schacht. California UPr, Berkley-California, 1994, pp. 306-317. (Vö. Deleuze [1999] 175-229., és különösen 175-204. o.)

${ }^{264}$ Vö. JR 186-203.§

${ }^{265}$ Ld. KSA 12.160 „Die Frage nach der Herkunft unserer Werthschätzungen und Gütertafeln fällt ganz und gar nicht mit deren Kritik zusammen, wie so oft geglaubt wird: so gewiß auch die Einsicht in irgend eine pudenda origo für das Gefühl eine Werthverminderung der so entstandenen Sache mit sich bringt und gegen dieselbe eine kritische Stimmung und Haltung vorbereitet."

${ }^{266}$ Vö. Winfried Schröder: Moralischer Nihilismus. Radikale Moralkritik von den Sophisten bis Nietzsche. Reclam, Stuttgart,2005, s. 31-34.
} 
egy Isten, nincs egy Igazság. Viszont csak egy világ van és egy Önmagam: e két végesség rejti magában a végtelent, Isten halálával pedig visszanyertük a jogot és a lehetőséget annak visszaszerzésére. A Semmi akarása végül önmagát számolja fel, ${ }^{267}$ méghozzá azért, mert az akarás természete szerint már mindig elérte a célját. Az akarás az egyetlen olyan mozgás, amely a hiány és a beteljesülés között önmagához örökké visszatér - épp ezért csakis ez lehet minden élet ,alapja-nincs” alapelve.

\section{5. Az ,aktív differencia” mint minden érték átértékelése: A hatalom akarása}

Mielőtt rátérnénk Nietzsche egyik - keletkezésének körülményeit és hatástörténetét tekintve legalábbis minden bizonnyal - legproblematikusabb írásának elemzésére, próbáljunk egy kicsit közelebb férkőzni a „hatalom akarása” terminus voltaképpeni jelentéséhez. Nehezen megragadható, minden ízében differenciális gondolat révén célszerünek tünik óvatosabban, negatív módon megközelíteni a kérdést; nézzük tehát, hogy mi nem a „hatalom akarása". Először is, a hatalom nem valamiféle reprezentáció; nem egy empirikus cél, melyre az akarat irányul, melyet mindnyájan ugyanakként akarhatnánk. De maga az akarat sem jelenti cselekedeteink okát, szubjektivitásunk forrását, ahogyan azt a szabad akarat különféle elméletei hirdetik. Nem úgy áll a dolog, ahogyan Schopenhauer gondolta (a kanti antropológiai fordulatot szándékozván meghaladni), hogy tudniillik az akarat magánvaló szubsztanciája révén válik a jelenségek minket körülvevő világa számunkra-valóvá, amennyiben minden jelenség ezen magánvaló akarat manifesztációja. Hiszen, mint azt korábban már említettük, Nietzsche szerint már Kant is tévedett, egyáltalában a Ding an Sich tételezésével - nincsenek elmefüggetlen létezők, nincs másik „,valóság”.

Nietzsche jegyzeteiben és levelezésében már 1884-től kezdve rendszeresen felbukkan az értékek átértékelésének gondolata, a „hatalom akarása” terminus pedig még 1876-ban tünik fel először, a következő kontextusban:

\footnotetext{
${ }^{267}$ Vö. MG III:27.§, „Minden nagy dolog önmagát pusztítja el az önmegszüntetés aktusa révén: így akarja az élet törvénye, a szükségszerü »önlegyőzés « törvénye, mely az élet lényegéből fakad - végül azonban mindig magára a törvényhozóra száll az ítélet: patere legem, quam ipse tulisti.” - A keresztény Istent a ,jó európai” győzte le. (Vö. VT 357. §)
} 
A becsvágy alapeleme a hatalom érzésére való vágyakozás. A hatalom élvezete nem a mások csodálata felett érzett örömre vezethető vissza. Dicséret és szidás, szeretet és gyülölet egyformák a becsvágyó számára, aki hatalmat akar. A félelem (negatív) és a hatalom akarása (pozitív) az emberek véleményétől való erős függésünket jelzi. - A hatalomvágy a függöség, a tehetetlenség százszorosan átélt fájdalmából ered. Ahol hiányzik ez a tapasztalat, ott a vágy is hiányzik. ${ }^{268}$

Az akarás mindig hiányból ered és a beteljesülésre törekszik; az akarás ösztön, idegi mechanizmus, tehát nem szellemi, hanem fizikai eredetű, bármire is irányul. A ,hatalom akarása” gondolatában éppen az ember alapvetően testi-ösztönös, nagyon is „evilági” mivolta nyilvánul meg. Még erényeink eredete sem más, mint a hatalomakarás: a másik feletti hatalom vágya; az akarás mindig irányul valamire, de az akarat minden egyes akarásban önmagát akarja. Közelebbről: nincsen ,akarat” mint egység; az „akarat” kifejezés mindig egy hierarchiát tükröz, erők harcának pillanatnyi állását. Az ember az akarásban sem nem szabad, sem nem individuum, hanem mindig csak dividuum, mely minden döntésével előnyben részesít egy ösztönt egy másikkal szemben. De nem vezet-e egy ilyen gondolatmenet végtelen regresszushoz; az alárendeléseknek ebben az örvénylésében nem veszítjük-e el végül egységünkkel együtt egyediségünket is? Nem, mégpedig éppen azért nem, mert minden, ami él, az a hatalom akarása. Az élet: hatalomakarás, az igazságvágy: hatalomakarás, az erkölcs: hatalomakarás, a hit: hatalomakarás, a szeretet: hatalomakarás. A nietzschei vállalkozás tétje nem kevesebb, mint $A$ hang és a fenomén Bevezetésében Derrida által a ,jelenlét metafizikai tradíciójának"269 nevezett hagyomány, vagyis az európai filozófia mint olyan meghaladása. Ez ugyanis Platón óta jelenlét és távollét terminusaiban gondolkodik az emberi létezésről, és a megismerés, a morál és a vallás területén is ezek integrációjára, azonossá-tételére törekszik. Jelen disszertáció egyik legfontosabb célkitüzése Nietzsche gondolkodásának paradigmatikus differencia-filozófiaként történő bemutatása, így számunkra a hatalom akarásának ezen átfogó értelme kiemelkedő jelentőséggel bír. Nem kevesebbről van ugyanis szó, mint a Lét [Sein] és a létrejövés [Werden] különbségének felismeréséröl, közelebbről: az ontológiai

\footnotetext{
${ }^{268}$ Vö. KSA 8.425 „Das Hauptelement des Ehrgeizes ist, zum Gefühl seiner Macht zu kommen. Die Freude an der Macht ist nicht darauf zurückzuführen, dass wir uns freuen, in der Meinung anderer bewundert dazustehen. Lob und Tadel, Liebe und Hass sind gleich für den Ehrsüchtigen, welcher Macht will. Furcht (negativ) und Wille zur Macht (positiv) erklären unsere starke Rücksicht auf die Meinungen der Menschen. Lust an der Macht. Die Lust an der Macht erklärt sich aus der hundertfältig erfahrenen Unlust der Abhängigkeit, der Ohnmacht. Ist diese Erfahrung nicht da, so fehlt auch die Lust." (kiemelések tölem, L.E.)

${ }_{269}$ Vö. Jacques Derrida: A hang és a fenomén. A jel problémája Husserl fenomenológiájában. Ford. Seregi Tamás. Kijárat, Bp., 2013. 16. o.
} 
differenciaelfelejtése helyett annak rögzitéséröl. A hatalom akarása a különbség kinyilvánítása, a differencia igenlése, és mint ilyen, az értéktételezés egyedül lehetséges elve.

Minden érték átértékelésének koncepciója eleinte az örök visszatérés gondolatával együtt, egészen pontosan az örök visszatérés filozófiáját kifejteni hivatott könyv terve kapcsán merül fel a jegyzetekben, ${ }^{270}$ az átértékelés feladatát csak 1885 őszén-telén veszi át végleg a hatalom akarása. ${ }^{271}$ Nietzsche a kezdetektől négykötetesre tervezte a művet, ezen belül azonban vannak tematikai eltérések a különböző variánsok között. Hagyományosan az Elisabeth Förster-Nietzsche és Peter Gast által szerkesztett változatot szokás $A$ hatalom akarásaként olvasni, melyet Nietzsche 1887. március 17-i tervezete ${ }^{272}$ alapján állítottak össze; mi tehát (a szerkesztők „önkényének” figyelembe vételével, melynek példátlan mértékéről Mazzino Montinari részletesen beszámol ${ }^{273}$ ), a következő előfeltevések figyelembe vételével olvassuk „A hatalom akarása” címü kompilációt: 1. Nietzsche, 1885 második fele környékén, valóban tervezett egy ilyen címü könyvet, ez azonban ebben a formában soha nem készült el. 2. Minden érték átértékelését eleinte az örök visszatérés gondolatára kívánta alapozni. 3. A hatalom akarása mint rendező elv akkor vált fontossá, mikor Nietzsche az értékek átértékelésének koncepcióját konkrétan az ,,igazság akarása” évezredes hagyománya, azaz a teljes filozófiai hagyomány ellenében határozta meg; és ennek folyományaként egy rövid ideig még a rendszeralkotást is fontolóra vette. 4. A Nachlass, és különösen Nietzsche személyes levelezésének tanúsága szerint azonban Nietzsche erről a tervéről letett, és a könyvbe szánt, számozott töredékek sora megszakadt. A mü, melyet Nietzsche maga minden érték átértékelése betetőzésének tekintett, Az Antikrisztus; míg a dionüszoszi filozófia foglalatát $A$ bálványok alkonya tartalmazza. Ezekkel a müvekkel a következő fejezetben foglalkozunk. Most tehát a Förster-Gast féle kompilációt, mint a Nietzsche által 1887-ben még $A$ hatalom akarása címen megírni tervezett, de torzóban maradt könyvének a szerkesztők

\footnotetext{
${ }^{270}$ Vö. KSA 11.218 „Philosophie der ewigen Wiederkunft. Ein Versuch der Umwerthung aller Werthe.”; 11.225 „1. Der Gedanke: seine Voraussetzungen, welche wahr sein müßten, wenn er wahr ist was aus ihm folgt 2. als der schwerste Gedanke: seine muthmaßliche Wirkung, falls nicht vorgebeugt wird d.h. falls nicht alle Werthe umgewerthet werden 3. Mittel ihn zu ertragen die Umwerthung aller Werthe: nicht mehr die Lust an der Gewißheit sondern an der Ungewißheit nicht mehr „Ursache und Wirkung“, sondern das beständig Schöpferische nicht mehr Wille der Erhaltung, sondern der Macht usw."

${ }^{271}$ Vö. KSA 12.109 „Der Wille zur Macht. Versuch einer Umwerthung aller Werthe. In vier Büchern.”

${ }^{272}$ KSA 12.318, , [+++ ] aller Werthe Erstes Buch. Der europäische Nihilismus. Zweites Buch. Kritik der höchsten Werthe. Drittes Buch. Princip einer neuen Werthsetzung. Viertes Buch. Zucht und Züchtung. entworfen den 17. März 1887, Nizza. I. Jede rein moralische Werthsetzung (wie z. B. die buddhistische) endet mit Nihilismus: dies für Europa zu erwarten! Man glaubt mit einem Moralism ohne religiösen Hintergrund auszukommen: aber damit ist der Weg zum Nihilismus nothwendig. In der Religion fehlt der Zwang, uns als werthsetzend zu betrachten.”

${ }^{273}$ Mazzino Montinari: „Nietzsche hagyatéka 1885-től 1888-ig avagy a szövegkritika és A hatalom akarása.” Ford. Kiss Endre. In: Filozófiai Figyelö, 1986/I. 94-113. o.
} 
által erősen „meghúzott” változatát olvassuk, melyet azonban nem tekintünk a szerző minden érték átértékelésére vonatkozó terve megvalósításának. Elfogadjuk ugyan a könyv tematikáját, de csak két megszorítással: elöször, hogy azt egy olyan kötet tartalomjegyzékeként olvassuk, mely végül a szerző tudatos döntése nyomán nem jelent meg; másrészt azonban, bár a négy fejezetcímet Nietzsche számára kiemelt jelentőségű problémáknak tekintjük, folyamatosan tudatában vagyunk annak a ténynek, hogy az aforizmák címek alá történő besorolása pusztán a szerkesztők, nem pedig a szerző intencióját tükrözi. Jelen dolgozat keretei között nem áll módunkban ennél részletesebben tárgyalni $A$ hatalom akarása címen megjelent, Nietzsche hagyatékából összeállított kompiláció közismerten zavaros keletkezési körülményeit; a további tájékozódáshoz Mazzino Montinari már említett tanulmányát javasoljuk.

Nietzsche előrebocsájtja: a legfontosabb dolgokról lesz szó, méghozzá ennek megfelelően ,ártatlan - cinikus”, vagyis semmilyen bevett értéket nem tisztelő, semmit el nem hallgató módon. Nem kétséges, mi vár ránk; a következő két évszázad a „nihilizmus térhódításának” kora lesz. Az európai civilizáció nem kerülheti el sorsát, mert gyáva ahhoz, hogy saját felszíne alá ásson, és tévedései okát kutassa. Kíméletlen őszinteségre és az ártatlanságig fokozott merészségre van tehát szükség; a vállalkozás tétje ugyanis múltunkkal és jövőnkkel való szembenézés. Nietzsche, mint mondja, olyan emberként veszi magára ezt a szerepet (tudniillik a genealógusét, az ,aranycsinálóét”, a paprikajancsiét), aki már végigjárta a nihilizmus útját, akiben a nihilizmus a semmivé-válás akarásaként már beteljesedett. A látszat ellenére azonban szó sincs semmiféle pesszimizmusról; épp ellenkezőleg. Az önmagát akaró akarás tevékenységéről van szó, mely ekként van jelen a „szabad szellem” önteremtésében, akárcsak a nihilizmus önkiteljesítő-önmegsemmisítő mozgásában. ${ }^{274} \mathrm{~A}$ következőkben a nihilizmus, a par excellence életellenes erő munkáját követhetjük nyomon; mely egyet jelent a „keresztény-morális értelmezés”, más néven erkölcsi világrendünk történetének áttekintésével. Látni fogjuk: a nyugati, metafizikus, keresztény berendezkedést végül saját racionalizmusa és moralizmusa hajszolja nihilizmusba, ezzel pedig önfelszámolásba.

\footnotetext{
${ }^{274}$ Vö. HA Elöljáró beszéd. $4 . \S$ „Ám ne tévesszük el a cím értelmét, amelyet e jövö-evangéliumnak akarunk adni. »A hatalom akarása. Minden érték átértékelésének kísérlete« - e formulával egy ellentétes irányú mozgást juttatunk kifejezésre, a feladat és az alapelv tekintetében: azt a mozgalmat, amely a bizonytalan jövöben ezt a bizonyos tökéletes nihilizmust leváltja majd; amely azonban fel is tételezi logikailag és lélektanilag a nihilizmust és csak rajta alapulhat, csak belöle származhat.”
} 
„Mit jelent a nihilizmus? - Hogy a legfőbb értékek elértéktelenednek. Hiányzik a cél; hiányzik a válasz a »miért?«-re." ${ }^{\text {275 }} \mathrm{Az}$ igazság iránti vágyunk mára olyannyira elhatalmasodott, hogy többé már nem hihetünk Istenben, túlvilágban, magánvaló létezésben a semmi akarása radikalizálódott. A kereszténység bizonyos szempontból jótevőnk volt, megóvott ugyanis a nihilizmustól; de egy hazugság árán. Mivel nyilvánvaló, hogy a földi élet véges, hogy nincsenek benne örök igazságok és így alapjában véve igazságtalan, szükségünk volt a túlvilágra, ahol mindezen értékek csorbítatlanul megjelenhettek. Láthatjuk: moralitásunk és hitünk feltétele a keresztény-erkölcsi világrendben nem más, mint a földi, evilági élet megtagadása. A kétely megjelenésével tehát legelőször létezésünk célját (ti. „értelmét”), majd a koherencia egység-érzését, végül pedig a „hitet” mint olyat (Istenben, Igazságban, túlvilágban) veszítjük el. Végül a pesszimizmus nihilizmusba fordul, és egészen addig fokozódik, míg be nem köszönt a tökéletes üresség, a Semmi uralma.

Különbség van azonban aktív és passzív nihilizmus között: előbbi ,,a szellem fokozott hatalmának jele” (ilyen például az oroszok nemet-cselekvő, fatalista nihilizmusa), míg utóbbi „a szellem fokozott hanyatlása és csökkenése” (a schopenhaueri-buddhista akarat-tagadás). ${ }^{276}$ Az említett kér ,irányzat” azonban legalább szembenéz Isten halálával (kiteljesedett nihilizmus), és nem próbál tudomást sem venni róla, sem pedig az abból következő értékválságról, ahogyan a materialista-pozitivista irányzatok teszik (részleges nihilizmus). Mindezekkel szemben áll Nietzsche dionüszoszi, ,affirmatív extatikus nihilizmusa”, 277 mint az egyetlen valóban pozitív reakció Isten halálára. A kérdés az, hogy mihez kezd az ember egymagában, miután a végsőkig hajtotta a nihilizmust: kimondta a végső Nem-et, mellyel a Földet eloldozta Napjától. Új Napokat keres, vagy csak „oroszosan” lefekszik a hóba, és várja a halált? ${ }^{278}$ Netán egyáltalán nem tesz vagy akar semmit? A nihilizmus központi problémává emelésével Nietzsche megkerülhetetlenné teszi az ember számára a jövőjével kapcsolatos döntés meghozatalát. Az emberiség eddigi története: a nihilizmus története; jövőnkről pedig most kell döntenünk. ${ }^{279}$ Ugyanarról van szó, mint $A$ tragédia születésében az erősek, illetve a gyengék pesszimizmusa kapcsán. Az erős nem kér semmilyen vigaszból, nem menekül a Semmi fenyegetése elől. A keresztény morál és vallás gyengék és erősek ezen alapvető különbségét megfordítja, s ezután a gyenge lesz a jó, pusztán azért, mert többségben van, az erős pedig, ugyanezen az elven mindössze mássága folytán lesz rossz. Gyengék és erősek

\footnotetext{
${ }^{275}$ HA $2 . \S$

${ }^{276}$ HA 22. §

${ }^{277}$ Michael Allen Gillespie:,,Nietzsche and the anthropology of nihilism.” In: Nietzsche-Studien 28. 1999, p. 142.

${ }^{278}$ Vö. JR 208.§

${ }^{279}$ Vö. Gillespie (1999) pp. 141-143.
} 
különbsége az életösztönök erején mutatkozik meg, a bennünk rejlő hatalomakarás potenciálján; ezért lesz az elsőszámú nihilista érdek az ilyen distanciateremtő ösztönök felszámolása. Minden társadalom szükségszerüen elöregszik, túlhaladottá válik a nihilizmus törvényszerü müködése nyomán, amely így voltaképpen az emberi történelem hajtóereje. Ebből következően viszont a társadalom öregedésének, hanyatlásának válságtünetei; a dekadencia és a pesszimizmus is időről-időre felbukkannak. Nietzsche ezért az Igen és a Nem müvészetét tanítja: Nem mindenre, ami az élet ellen szól, és Igen magára az Életre, az erő felhalmozódására. Amint a pesszimizmus szélsőségessé válik, nihilizmussá alakul; de az élet elleni fenyegetés egy ponton túl saját ellenhatásába csap át, és az életerő növekedését eredményez: a Semmi akarása a hatalom akarásává kristályosodik. Döntő fontosságú, hogy helyesen értsük ezt az átalakulást: nem az ellentétpár egyikéből a másikba történő, ugrásszerü átmenetről van szó, hanem a szó kémiai értelmében vett átkristályosodásról, azaz átlényegülésről: ugyanaz az anyag, különböző állapot. „A nagy délidő, az iszonyatos felfénylés kora ez: az én pesszimizmusom: - nagy kiindulópont.",280

Az „,eddigi legnagyobb értékek”, közelebbről a vallás, a morál és a megismerés (azaz a filozófia) kritikájának tematikája - a szerzői szándék esetünkben közismerten komplikált és megkérdőjelezhető voltát figyelembe véve is - alapvetően megfelel a genealógia alapok felé mélyülő módszerének; hiszen minden tévedésünk eredete az Igazságba vetett hitünk; ez esetben tehát a megismerés mint olyan problematizálása a genealógus végső-utolsó feladata. A hívő elődlegesen egy pszichológiai típus: az az ember, aki nem meri boldogsága, élvezete, általában vett jólléte okát önmagában keresni; hiszen ha így tenne, mindezek hiányára sem találna önmagán kívüli magyarázatot. Az ilyen típusnak szüksége van egy nálánál erősebb, felettes hatalomra, melyre döntéseit, felelösségét és boldogságát: létének teljes súlyátátháríthatja. Mindezek után magunknak már csak a gyenge, megvetendő tulajdonságokat tarthatjuk meg - nevezzük ezeket most nagyon is „emberinek” -; minden, ami erős és csodálatra méltó, átkerül a „túloldalra”, s ettől kezdve ezekből maximum részesednünk lehetséges. Ez utóbbi, kizárásos alapon, az „isteni” terrénuma. ${ }^{281}$ A keresztény Isten még csak nem is szól közvetlenül az emberhez, csak „földi helytartóin”, a papokon keresztül - ők közvetítik az áldást és kegyelmet, kinek-kinek „érdeme” szerint. Nietzsche a kereszténység mellett, passzivitása miatt, a buddhizmust is nihilista vallásnak tartja, mégis különbséget tesz: a buddhistákból hiányzik a múlttal szembeni „keserüség, csalódottság és

\footnotetext{
${ }^{280}$ HA 134. §

${ }^{281}$ Vö. pl. HA $135 ; 136 ; 141$; illetve $331 ; 336 ; 344 . \S$
} 
neheztelés”. Utóbbi, bár eredendően nem keresztény, hanem zsidó találmány; mégis adódik egy fontos eltérés a két koncepció között: a „túlvilág” a zsidó vallásban Mózes elnyomott népének bosszúja az erősebbeken; a kiválasztottság-gondolat alapvetően eszköz az életben maradáshoz. A keresztény morál azonban nem egyszerüen passzív, hanem egyenesen reaktív: a paradigmatikus tagadás, a ressentiment morálja a kezdettől fogva a gyengéknek az erősekéivel szembeállított értékein alapul. ${ }^{282}$

Márpedig Nietzschénél a morál: értékbecslés, méghozzá mindig is szigorúan igazságtalan módon. ${ }^{283}$ Már a „,szabad szellem-trilógia” elemzésekor láttuk, hogy Nietzsche a morál eredeténél fiziológiai ingerekre adott fiziológiai reakciókat talált, és hogy ily módon értelmét vesztette a „morális jelenségekről” való beszéd. ${ }^{284}$ A morális értékbecslések adott jelenségek partikuláris interpretációi, melyeket azonban, közmegegyezéssel, egyedül lehetségesként fogadtunk el. Mivel tehát ítéleteink abszolút érvényre tettek szert, megfelelő hatalommal bírnak a „csorda” felett, amely természete szerint igényli az irányítást. A tömegember azonban mégsem érzi magát kiszolgáltatottnak, hiszen ott van neki „szabad” akarata. Holott, mondja Nietzsche, ,jó” és „rossz” dualizmusa valójában nem más, mint egyazon erő szétválasztása két ellentétes pólusra; így mindkettő csak a másik révén kaphat létjogosultságot; miközben ,jó” és „rossz” valójában távolról sem egymás ellentétei, hanem „komplementer értékfogalmak”, hiszen az élet maga is „minden ösztönében egyaránt tartalmazza az Igent és a Nemet”. ${ }^{285}$ A dualisztikus gondolkodás célja az ellentétek azonossátétele, a különbség eltörlése; a gyenge ember a tőle különbözőt pusztán különbözősége folytán mondja rossznak. Az erős embernek ezzel szemben azért van szüksége ellenfélre, hogy legyőzhesse, nem pedig, hogy megsemmisítse, hiszen tudja, hogy a különbség tartja fenn erejét.

Nietzsche éppen a kritikai gondolkodás hiányát veti a nyugati filozófiai tradíció szemére. Hiányolja a történeti érzéket, a fiziológiai ismereteket és a gyakorlati célt; összességében úgy véli: valódi kritikai tevékenység helyett pusztán moralizál. Talán még $A$ tragédia születésében meghirdetett „esztétikai világnézet” mélyén is maradt egy morzsányi moralitás: hiszen mi más a szépség akarása, mint a csúf megsemmisítésének vágya? Ebben különbözik a dionüszoszi bölcsesség, mely a pusztulásban már a keletkezést ünnepli, melyben a pesszimizmus túlhaladottá, a vigasz pedig szükségtelenné válik; melyben a moralitást eltörli

\footnotetext{
${ }^{282}$ Ld. pl. HA $137 ; 139 ; 141 ; 154 ; 155 ; 183 ; 185 . \S$

${ }^{283}$ Vö. HA 274. §

${ }^{284}$ Vö. HA 253. §

${ }^{285}$ Ld. HA $351 . \S$
} 
az erő. - „Az általános széthullás bénító képével az örök visszatérést szögeztem szembe."286 A nyugati filozófia lezüllése Szókratész megjelenéséhez köthető, aki az ész=erény=boldogság dialektikus azonosságtanával kimondta $a$ primordiális, paradigmatikus morális elöitéletet: ami ésszerü, az erényes, ami erényes, az boldoggá tesz; tehát csak az „ésszerü” cselekvés tesz boldoggá. A boldogság absztakciója az erkölcsi világrend legalapvetőbb gondolata; a szókratészi optimizmus pedig, szinte paradox módon, a nihilizmus első megjelenése. Nietzsche célja nem a morál eltörlése, hanem annak visszavezetése természetes gyökereihez: a gyönyör és fájdalom alapérzéseihez. Az ismeretelmélet így affektus-tan lesz, méghozzá egyfajta perspektivikus és hierarchikus szervezettségben, melyet ugyanakkor épp a perspektíva és a hierarchia hivatott megóvni a rendszerré szilárdulástól. Nietzsche úgy véli, talán sosem volt még alkalmasabb az idő a dolgok mélyére ásni, mert a hit visszaszorulásával fokról fokra erősödik az ,újfajta érzékenység”, ${ }^{287}$ az átértékeléshez szükséges merészség; közeledik a „vigasz-talanság” kora, az Übermensch eljövetele.

A hatalom akarása gondolata „egy új értékmeghatározás elveként” kerül kifejtésre. A megismerésben a hatalom akarása az igazság akarásaként nyilvánul meg, amely azonban két okból is káros lehet: egyrészt hajlamosak vagyunk megfeledkezni arról, hogy úgynevezett „,igazságaink” pusztán megszilárdult metaforák, és elfelejtjük, hogy a gondolkodás mint az igazság akarása elsősorban a másként-gondolkodás akarását kell, hogy jelentse. Ehhez kapcsolódik a másik gyakori hiba, nevezetesen az interpretatív ösztön elhatalmasodása, melynek következtében a „belső tapasztalat” mostanra egyet jelent a szubjektív interpretációval, a valóság pedig gyakorlatilag jelentőségét veszti. Tehát emlékeztessük magunkat arra, hogy 1. nem csak interpretációk vannak: a szöveg is létezik; illetve 2. nem csak egyetlen lehetséges interpretáció van. A jövő filológiájának is szüksége van az „újfajta érzékenységre". A gondolkodásnak fel kell szabadulnia a szubjektivizmus uralma alól, hiszen minden igazságakarásnak saját perspektívája van; Isten halálával az igazságok és az interpretációk végtelenje tárul fel a megismerő előtt. Az észlelés az igaznak-tartás első tevékenysége - tehát a hit az, ami szükségszerü, nem pedig a hit tárgyának létezése. ${ }^{288} \mathrm{~A}$ létezés csak perspektivikus, tehát esztétikai jelenségként „igazolható”. ${ }^{289}$ Nincs többé „én”,

\footnotetext{
${ }^{286} \mathrm{HA} 417 . \S$

${ }^{287}$ Ld. pl. H I:49.§ „Az új alapérzés: végleges mulandóságunk.”; H I:52.§ „A vigasz eszközei voltak azok, amelyek áltzal az élet elöször kapta meg azt a gyászos alapkaraktert, amelyben most hiszünk.”; H I:54.§ „Megnyugtatni a beteg fantáziáját, hogy legalábbis ne kelljen szenvednie, mint eddig, inkább a betegséggel kapcsolatos gondolataitól, mint magától a betegségétől - úgy gondolom, ez már valami! És ez nem kevés! Most már értitek, miben áll a feladatunk?"

${ }^{288}$ Vö. HA 506. illetve 507. §

${ }^{289}$ Vö. TSZ 54. o.
} 
mint az ember ésszerü és morális szubjektuma: a szubjektum: sokaság, mely éppen „átmenetisége és megfoghatatlansága” folytán nem más, mint „halandó lélek”. 290

Az igazság akarása mint az azonosság, az általánosság akarása egyértelmủen a hatalomakarás megnyilvánulása, holott a mozdulatlanság nem csak a tökéletesség, hanem épp ellenkezőleg a mozgásképtelenség jele is lehet. Nincsenek ellentétek, csak különbségek, nincsen lét és nem-lét, csak változás. A szubjektum-objektum kauzalitás, ahogyan azt $A$ nemmorálisan felfogott igazságról és hazugságról szóló korai, programatikus szöveg kimondja, optikai-grammatikai tévedés. Egy idegi ingert előbb képpé, majd hanggá alakítunk, s végezetül elhelyezzük a fogalmak „kolumbáriumában”; a reprezentációnak ezt a „tárgy” fogalmában rejlő alapvetően megtévesztő müködését tökéletesen illusztrálja a szó német alakja: „Gegenstand”, vagyis a velem szembenálló, a nem-én - ahogyan én látom. Ez a fajta ellentételezés lett gondolkodásunk alaptevékenysége, ezt kihasználva tudott Platón két világot teremteni - a kereszténység pedig világuralomra törni. A „másik világ” a filozófus, a „vallási ember” és a „morális ember” kimerült és tehetetlen dekadencia-ösztönének terméke. A dekadencia korszakait pedig mindig az életerő hanyatlása hívja életre, és mindig értékválság formájában jelennek meg; egy ilyen típusú krízisnek értelemszerűen csak egy újfajta értékelésmód megjelenése vethet véget. A bizonyosság akarásából egy idő után eltünik az akarás ereje, és a bizonyosság lesz az úr; ezzel szemben a hatalom akarása soha, egy pillanatra sem rendelődik alá semmi másnak, nála nincs erősebb akarás. „Mert a hatalom akarása nem lét, nem is levés, hanem pátosz - a legelemibb tény, amelyböl majd levés, valamivé válás és hatás áll elő." ${ }^{291}$ Minden életet a hatalomakarás pátosza tart fenn, sőt, még az ember „szándékos” cselekedetei mögött is a hatalom akarása müködik. Holott, mint már említettük, nincsen egységes „akarat”; az akarás mindig valamit-akarás, az eseményt csak a kauzalitás eszméje választotta szét cselekvőre és cselekvésre, így osztva azonosítható egységekre a végtelent - az akarat eredendő intencionalitása a legerősebb érv bármiféle atomisztika ellen. $^{292}$

\footnotetext{
${ }^{290}$ Vö. HA 490. § Nietzsche a III. könyv 489-493. aforizmájában a test és lélek organikus egységeként értett „Önmaga” Zarathustra-beli koncepcióját mélyíti el.

${ }^{291}$ HA 635. §Idézzük fel a görög eredetü „pátosz” szó etimológiáját: a pathosz (szenvedés, indulat, szenvedély) fönév a pathétikosz (szenvedélyes) melléknév és a paszkhó (elvisel, elszenved) igéből származik, és tökéletesen kifejezi a szenvedély mint olyan és a szenvedés, helyesebben: el-szenvedés, eredeti összetartozását.

${ }^{292}$ Richard Schacht helyesen jegyzi meg, hogy a hatalom akarása legteljesebb értelmében a „világ” (vagyis az eleven élet) homogenitásának koncepciója (amint azt $A$ hatalom akarása utolsó, 1067. töredéke is egyértelmüvé teszi). 1. Az, hogy Nietzsche a hatalom akarását az erö általános müködési elveként egyrészt módszertanilag gazdaságos, mondja Schacht, emellett a mechanisztikus világnézet (és vele együtt a metafizika) kritikája is. Az erő mint a müködés általános elve ugyanis nem lehet pusztán intelligibilis fogalom; olyannak kell lennie, amit el tudunk képzelni, mint müködést. Az erö, mint a hatalom akarása legalapvetőbb emberi tapasztalatunk, és mint
} 
Az utolsó években Nietzsche visszatér a művészetekhez, de már nem a művészmetafizika értelmében, hanem nagyon is testi, nagyon is ösztönös módon. ${ }^{293}$ Nietzsche már a „szabad szellem-trilógia” óta a teremtőkhöz szól; de nem a „fátyolkészítőkhöz”, ${ }^{294}$ hanem a dionüszoszi, tragikus művészekhez, akik képesek a múltat, a jövőt, és saját magukat akaratukkal újrateremteni. Újra a gyermek Zeuszt látjuk, aki kénye-kedve szerint rombolja le és kezdi újra játékát; Nietzsche ilyen gyermeki-müvészi ártatlanságot vár teremtő-társaitól. ${ }^{295}$ Az alkotás ösztönének három alapeleme a nemi ösztön (ti. a teremtés-termékenyítés vágyát), a mámor és a kegyetlenség; mindezeket azonban egy naiv, ártatlan, „első mozdulat” foglal egységbe - Nietzschét minden bizonnyal lenyügözte volna a „vadak” festészete. A müvészi ösztönben még mindig az apollóni és a dionüszoszi erők keveredését érzi: a „vizionárius kényszer” és az „orgiasztikus kényszer” a műalkotást álom és mámor keverékévé varázsolja. Nietzsche kései művészetfilozófiájában a mámor dionüszoszi fogalmának kulcsszerepe van: távolról sem puszta kéj, sokkal inkább a „mozgás, a szenvedély, az ének és a tánc erejét” felszabadító hatalom. A mámorban az ember átlényegül. ${ }^{296} \mathrm{~A}$ művészet az egyetlen, mely képes felvenni a harcot a nihilizmus kegyetlen igazságával, hiszen benne a pátosz életre kel, az akarat pedig a teremtéssel válik egyenlővé: ${ }^{297}$ „Az élet igenlésének legmagasabb rendü állapotát koncipiáljuk, amelyből nem vonható ki a legnagyobb fájdalom sem: a tragikusdionüszoszi állapotot”, ${ }^{298}$

Az „Idomítás és tenyésztés” címet viselő negyedik könyv aforizmái a „rangsor” nietzschei tanát az erőmennyiségek rendjeként leplezik le. Az erősnek nincs oka félni a hierarchiától, csak a gyengének - ezért él a gyenge ember inkább tömegben. Ahhoz tehát, hogy ismét az erősek uralkodjanak, újra kell teremtenünk a rangsort. Ehhez először is ki kell emelnünk az erőseket a tömegből - méghozzá a különbség erejével. Az erős embernek ugyanis, mint már említettük, esze ágában sincs megsemmisíteni a gyengét, hiszen akkor nem lenne kin uralkodnia. A különbség, melynek révén az erős emberek elkülönülnek a tömegtől: „a distancia mint pátosz; a szabad lelkiismeret azokban a dolgokban, amelyeket ma roppant

\footnotetext{
ilyen, alkalmas arra, hogy minden müködés alapelve legyen anélkül, hogy puszta elv maradna. 2. Maga a „hatalomakarás” azonban éppen, hogy nem homogén: nem egység és nem mennyiség. A hatalom akarása az egymásnak feszülő akaratok feszültsége, uralmi rendszer, hierarchia, maga az elevenség. (Vö. Schacht [1985] pp. 212-217.)

293 „Egy anti-metafizikai világnézet - igen, de artisztikus.” (HA 1048. §)

${ }^{294}$ Vö. EH 119. o. „A németek nem akarnak tisztában lenni önmagukkal.”

${ }^{295}$ Vö. Z I:1560-1720 „A teremtő útjáról.”

${ }^{296}$ Vö. HA 796-808. §

${ }^{297}$ Vö. Deleuze (1999) 113. o.

${ }^{298}$ HA 853. §
} 
mód alábecsülnek és a lehető legerősebben megtiltanak". ${ }^{299}$ Az erős ember az, aki azután Igent és Nemet mondva kiválaszt és rangsorol, aki megteremti a növekedés új lehetőségeit; erős és előkelő a teremtő típusának két neve. Nietzschénél az élethez való jog a vállalt kötelességekkel arányos; mivel azonban a legtöbb ember nem vállal, csak elvisel; keveseknek van joga az élethez. Nietzsche morálja ezzel valóban túllép minden „emberin” - nyoma sincs már benne részvétnek. Ugyanakkor azt is látnunk kell, hogy mindebben szó sincs semmiféle népirtásról. Nietzsche nem az öregeket és a betegeket akarja kiirtani: célja a gyenge embertípus, a tömeg uralmának megszüntetése. Amíg ugyanis tömeg hatalma érvényesül, addig nincsenek igazi uralkodók, ugyanis a csordának nem király kell, hanem pásztor. Nietzsche olyan embereket akar, akik megküzdenek az élettel - az életért. Az előkelő ember nem csak gazdag, hanem tékozló is - azért, mert ő maga akarja így, és mert az igazi gazdagság túlcsordul önmagán. ${ }^{300}$ Nietzsche morálja túl van ,jón” és „,rosszon” - ,a »szellem szabadsága«, vagyis a hitetlenség mint ösztön, a nagyság előfeltétele”. ${ }^{301}$ A „szőke bestia” elsődleges értelmében nem az ős-árja paradigmatikus típusa, hanem, ahogyan Nietzsche már A morál genealógiájában is egyértelmüen kifejti, az emberiség jobbítója, az „új barbár”, aki „őrült, abszurd”, „kiszámíthatatlan”, és „hátborzongatóan vidám”. ${ }^{302}$ Még egyszer: az Übermensch nem népirtó, hanem uralkodó; és nem „faj”, hanem típus- a legnemesebb értelemben!

Nietzsche „emberfeletti” embere nem a valóságtól szenved, hanem az életért. Ö az, aki képes mindenen felülemelkedni, még önmagán is, és minden hibát, minden hiányosságot az egész különbözősége révén szükségszerü részeként látni. Nem fél megölni Istent, és nem fél az utána maradó ürtől. Az emberfeletti ember nem féli a Semmit, hanem szétfeszíti azt; végtelenné teszi, majd meghódítja. Az emberfeletti ember az emberben rejlő lehetőség: egy meghatározatlan és meghatározhatatlan, kimondhatatlan, rejtélyes, csábító, veszélyes, ígéretes, igazságtalan jövő lehetősége. Ez a mi örökké visszatérő jövőnk - a létezés folyamatos önmeghaladása, az Élet mint a hatalom akarása - „dionüszoszi” filozófia: amor fati. „Az örök visszatérés azt jelenti, hogy a lét kiválasztás. Csak az tér vissza, aki igent mond, vagy amire igent mondanak."303

\footnotetext{
${ }^{299}$ HA 398. §

${ }^{300}$ Vö. HA 872, 898, 902, 935. §

${ }^{301}$ HA 963. § Ez lehetne a „,szabad szellem” legteljesebb definíciója... (kiemelés tőlem, L. E.)

${ }^{302}$ Ld. MG I:11; vö. HA 899, ill. 900. §

${ }^{303}$ Deleuze (1999) 290. o.
} 
Ha tehát a fentiekben Nietzsche filozófiáját a modernitás válságának problematizálásaként, illetve az ezen válság túlhaladására tett kísérletként értelmeztük, akkor most azt mondhatjuk, hogy Nietzsche diagnózisa: a nihilizmus; az általános megoldás pedig a különbség aktivizálásának programja. Az általunk bevezetett munkafogalom, az „aktív differencia" volt $A$ tragédia születésének Dionüszosza, a szellem szabadsága, Zarathustra, a hatalom akarása, a genealógia - de mindenekelött: az örök visszatérés. A vándor árnyékaként igyekeztünk végigkísérni az ember, a gondolkodó életútját - Nietzschénél lehetetlen szétválasztani e kettőt. Értelmezésünkben az „aktív differencia” volt az a sokáig rejtőzködő, de a kezdetektől jelen lévő momentum, mely a Fátum és történelemtől A bálványok alkonyáig vezette Nietzsche gondolkodását. Az „aktív differencia” az állandó változás, az eleven élet operatív ereje, mely először Nem-et, azután pedig Igen-t mond és cselekszik; amely az alapjait vesztett metafizikus gondolkodást először nihilizmusba, majd a dionüszoszi igenlésbe fordította át. ${ }^{304}$ Nietzschénél a nihilizmus szükségszerü következménye minden érték átértékelése: azzal, hogy az eddigi értékek értékét kétségbe vonja, nem a világot, az emberi létezést minősíti értéktelennek, hanem az említett értékeket. Mikor tehát Isten halálával az Egység, az Igazság és a Cél fogalmai világunk vonatkozásában értéküket és értelmüket vesztik, ezzel világunk maga mit sem veszít a sajátjából, minthogy az említett fogalmak sosem volt magánvaló értékük; a magánvaló érték mint olyan nem létezik. Nincs ,igazi világ”, csak a valóság van, melyben mi vagyunk az értékteremtők, és ahol a létezésnek nincs célja, ahol semmi nem létezik magánvalóan, ahol nincs Igazság és nincs Isten. ${ }^{305}$

\section{6. Az ,aktív differencia” mint dionüszoszi elem: az utolsó évek és az összeomlás}

Nietzsche életének utolsó éveiben már valóban remete-módra él. Az itáliai olcsó panziók és magánszállások állandó vendége; bázeli nyugdíjából nemigen futná többre (könyvei iránt Németországban továbbra sem nőtt a kereslet). Ezekben az években ugyan kedvező hírek érkeznek Észak-Amerikából, de Európában igyekeznek tudomást sem venni

\footnotetext{
${ }^{304}$ Nietzsche talán ezen a ponton kerül a legközelebb Hegelhez; és épp ezért itt látható a legjobban a hegeli és nietzschei gondolkodás alapvető polémiája. Hegelnél, mint láttuk, az ellentétek a Lét azonosságformájában szünnek meg ellentétek lenni, Nietzschénél azonban csak különbségek vannak, erőviszonyok; a hatalom akarásának a keletkezés és változás szükségszerüen örökké visszatérő, véletlenszerüségében mégis végtelen világa. A különbség az ellentét ellentéte.

${ }^{305}$ Vö. Danto (2005) pp. 1-17.
} 
róla. 1887 decemberében kezd levelezni a dán Georg Brandesszel, aki 1877 és 1883 között kapcsolatban állt a berlini társasági körökkel (köztük Louval és Paul Rée-vel, de a berliniek zöme wagneriánus), 1888 tavaszán pedig előadássorozatot tart Nietzschéről a koppenhágai egyetemen. ${ }^{306}$ Ez év áprilisában Nietzsche Heinrich Köselitz tanácsára Torinóba költözik, és a szokásos, nyári felső-engadini pihenőtől eltekintve itt is marad 1889 tragikus januárjáig. Eközben elszántan dolgozik „minden érték átértékelésén”; magát „aranycsinálóhoz” hasonlítja, aki azt változtatja arannyá, amit a többi ember megvet, így tehát ő valami újat hoz létre, és nem egyszerüen cserét bonyolít. ${ }^{307}$ A májustól augusztusig Sils Mariában töltött hónapokban megszületik Nietzsche filozófiai „eretnekségének” nagystílü summázata, $A$ bálványok alkonya, melynek eredeti címe „Egy pszichológus henyélése” lett volna; 308 szeptemberben pedig a Wagner esete ${ }^{309}$, mellyel még egyik legrégebbi barátját, a wagneriánus Malwida von Meysenbugot is sikerül elvadítania maga mellől. ${ }^{310} \mathrm{Az}$ értékek átértékelésének hatalmas feladatát küldetésként éli meg, mely valódi fordulópontot jelent majd az emberiség történetében. A föművet négy kötetesre tervezte, melyeket egyenként jelentetett volna meg; az első ezek közül már 1888 tavaszán készen áll; ma Az Antikrisztus. Átok a kereszténységre címen ismerjük. Ez, valamint az Ecce homo és Dionüszosz-ditirambusok ${ }^{311}$ és a Nietzsche contra Wagner ${ }^{312}$ kéziratos formában maradtak fenn, és csak Nietzsche halála után jelentek meg.

A bálványok alkonya Nietzsche filozófiája „in nuce”. ${ }^{313}$ Nietzsche kalapáccsal indul a „,bálványok” (tudniillik „,igazságaink”) ellen, de nem ész nélküli törés-zúzásról van szó; inkább kopogtatásról, az „üreghang” megszólaltatásáról, a bálványok „kifüleléséről”. De azok a „bálványok” bizony üresen konganak! Nietzsche még egyszer, minden eddiginél pikírtebb stílusban összegzi és árnyalja modernitáskritikáját. Tagadja az életellenes értékeket, egyúttal

\footnotetext{
${ }^{306}$ Levelezésükből kiderül például, hogy Nietzsche hallomásból ismerte Kierkegaard munkásságát. Ld. „Levél Georg Brandesnek, 1888. február 19.” In: Nietzsche (2008) 187. o. „Következő németországi utazásomra tervbe vettem, hogy Sören Kierkegaard pszichológiai problémájával foglalkozom...”

${ }^{307}$ Vö. Nietzsche (2008) 206. o.

${ }^{308}$ Vö. BVN-1888,1111. „Brief an Paul Deussen.” („Es ist bereits ein andres $\mathrm{M}<\mathrm{anu}>\mathrm{s}<\mathrm{kript}>$ bei meinem Verleger, das einen sehr strengen und feinen Ausdruck meiner ganzen philosophischen Heterodoxie giebt - unter vieler Anmuth und Bosheit versteckt. Es heißt: Müssiggang eines Psychologen.")

${ }^{309}$ Friedrich Nietzsche: „Wagner esete. Zenészprobléma.” Ford. Romhányi Török Gábor. In: U. ő: Wagnerről és Schopemhauerröl. Ford. Romhányi Török Gábor. Holnap, Bp., 2001. 7-42. o.

310 Megjegyzendő, hogy a Mester halála óta Cosima valódi rágalomhadjáratot indított Nietzsche ellen, értelmiségi körökben még jobb esetben megszállott különcnek, rosszabb esetben pederasztának tartják.

${ }^{311}$ A Dionüszosz-ditirambusok magyar fordításban elérhető itt: Friedrich Nietzsche: Versei. Ford. Csorba Győző et al., vál. Hajnal Gábor. Európa, Bp., 1989.

312 A Nietzsche contra Wagner magyar fordításban elérhető itt: Friedrich Nietzsche: Bálványok alkonya. Nietzsche kontra Wagner. Ford. Romhányi Török Gábor. Holnap, Bp., 2004.

${ }^{313}$ Vö. Nietzsche (2008) 236. o. Nietzsche levele Georg Brandeshez, 1888. október 20-án. „Ez az írásom a filozófiám in nuce - radikálisan, szinte a bünözésig...”
} 
minden érték átértékelésére szólít fel egy életigenlő gondolkodásmód szellemében; a „rendszeralkotó” filozófusokkal szemben viszont óvatosságra int. Számára az élet kötéltánc, melyhez könnyü láb és biztos akarat szükséges; az életakarat ugyanis a hatalom akarása, méghozzá az önmagam és létezésem feletti hatalom megszerzésének akarása. Az élet tagadása a dekadencia jele, mely az erkölcsi hanyatlásban és degenerációban érhető tetten - tehát éppen a korábban bünösnek mondott ösztönökre kellene igent mondanunk, mert az ösztön maga a hatalom akarása. Nietzsche számára a szókratészi racionalizmus a dekadencia első megnyilvánulása, hiszen az „én” fölötti uralom céljából a boldogságot az erényes, azaz ésszerü cselekvés függvényévé tette. Szókratész voltaképpen kettéosztotta a világot, ezzel pedig emberlétünk értékét kérdőjelezte meg: a racionalizmus a dialektikával, ellentmondás logikájával védekezik az ösztönök túlerejével szemben. A Nietzsche által oly nagyra tartott, preszókratikus Hérakleitosz ugyan szintén tagadta az érzéki tapasztalat relevanciáját, de épp, hogy nem az észnek az érzékekkel szembeni elsőbbsége mellett, hanem a tapasztalat egységének lehetősége ellen érvelve. Ahogyan korábban láttuk, az alapvető tévedés mindig ugyanaz, tudniillik a nyelvhasználatból eredő kauzális, szubjektum-objektum viszonyon alapuló gondolkodás. Hérakleitosznak abban már igaza volt, hogy a világban nincsen semmi állandó vagy önazonos, csak folyamatos keletkezés és alakulás, sokaság és különbség. Voltaképpen pont az ellenkezője történt annak, amit a platonikus-keresztény hagyomány évezredek óta próbál velünk elhitetni: nem az „ideális”, magánvaló létezésből származik a mi csökkentett értékü látszat-világunk, hanem fordítva: a változatlan és örökkévaló túlvilág az, ami puszta vágyálom, üres hazugság. A metafizikai szóhasználatban „valóság” és „látszat” különbsége a következőképpen áll: előbbi a lét feltételezett birodalmára utal, míg utóbbi a mi emberi, viszonylagos és változó világunkra, mely az előbbihez képest puszta „látszat”; másodlagos, csökkentett lét. Nietzsche maga épp ellenkezőleg úgy gondolja, csak a látszatvilág a valódi, míg a „létezés üres fikció”. ${ }^{314}$ A „létezés”, vagyis a magánvaló lét puszta kitaláció, ezzel pedig a köztük lévő különbség kérdése többé nem érdekes, annál problémásabbá válik azonban egymáshoz viszonyított értékük. Nietzsche érvelése szerint az ún. „valós” és a „látszólagos” világok attribútumait egyszerüen felcserélték, pontosabban előbbit a másik ellentéteként konstruálták, így a metafizikai világnézet nem több, mint „morális-optikai csalódás”. Sőt, mi több: felesleges is, hiszen ha mindezidáig még nem sikerült elérnünk, akkor nem is ismerhetjük, tehát sem kötelezettségeket, sem pedig vigaszt

${ }^{314}$ BA 24. o. 
nem jelenthet számunkra. Hogyan is lehetne egy olyan világ a miénknél „valóságosabb”, amelyről egyáltalában csak a mi világunk kategóriái alapján vannak fogalmaink? ${ }^{315}$

Arthur C. Danto A bálványok alkonya III. fejezete („Az »ész« a filozófiában”) kapcsán hívja fel a figyelmet egy számunkra kifejezetten plauzibilisnek tünő lehetőségre; nevezetesen, hogy bár a nietzschei gondolkodást hagyományosan az irracionalizmus és az egzisztencializmus előkészítőjeként értjük, mégis, empirizmusa révén számos ponton megelőlegezi a logikai pozitivizmust és az analitikus filozófiát. A legfontosabb az a nietzschei alap-tendencia, hogy inkább aláássa, mintsem cáfolni próbálja a metafizikusok állításait, mondván: ami irracionális, az nem szorul cáfolatra. Ez egybecseng azzal a pozitivista alapelvvel, hogy a filozófusok kijelentései legtöbbször nem igazak vagy hamisak, pusztán értelmetlenek; így aztán a filozófia örökérvényűnek titulált problémái valójában csak látszatproblémák. $^{316}$

Nietzsche a lét-problémát morális kérdéssé emeli, és azt állítja: a metafizikai világnézet kezdeteinél csalásra derül fény, míg a dionüszoszi, dinamikus világnézet a keletkezés ártatlanságát hirdeti. Létezésünknek nem lehet célja semmiféle állítólagos ideális állapottal való azonosság elérése; hiszen a természetben egyáltalán nincs befejezettség: nincsenek célok, ideálok vagy azonosság. Az emberi világ folyamatos, vég nélküli müködés; organizmus, amelyen kívül vagy túl nincs semmi - pontosabban csak a Semmi van. Az embernek pedig nincsen rendeltetése - léte szükségszerü, sorsa az amor fati. Isten halála szükséges volt, ugyanis ő maga volt eddig az élettel szembeni „legnagyobb ellenvetés”. ${ }^{317}$ A keresztény morál az önfeláldozás morálja, az élet tagadásának morálja; túl kell hát lépnünk „jón és rosszon”, és saját, pozitív értékeket kell teremtenünk. Ezt várja Nietzsche az Übermenschtől, az emberfeletti embertől, a radikális életigenlés megtestesítőjétől, aki oly mértékben ura saját ösztöneinek, hogy azok már nem is különböznek tőle. A par excellence „tragikus” ösztön maga „,az élet akarása”; Dionüszosz pedig az önmagát bőségének mámoros tudatában eltékozló, és az eltékozlásban újjászülető, önmagához örökké visszatérő Élet szimbóluma. Ezzel pedig Nietzsche is visszatért önmagához, filozófiájának alfájához és ómegájához: Dionüszoszhoz. ${ }^{318}$

\footnotetext{
${ }^{315}$ Vö. Richard Schacht: „Metaphysical Errors. A »true world« of »being«.” In: U. ő: Nietzsche. Routledge, London-New York, 1983. pp. 156-169.

${ }^{316}$ Vö. Danto (2005) pp. 64-65.

${ }^{317}$ Vö. BA 43. o.

318 Vö. BVN-1888,1137. „Brief an Heinrich Köselitz.” („Im Grunde habe ich’s nicht annähernd von irgend Jemand erlebt, zu hören, wie stark meine Gedanken wirken. Die Neuheit, der Muth der Neuerung ist wirklich
} 
A bálványok alkonyát Nietzsche 1888. szeptember 3-án zárta le, és azonnal hozzákezdett Az Antikrisztushoz, melyet szeptember 30-án be is fejezett; az összeomlást megelőző pár hónapban hihetetlenül termékeny volt. Sokan úgy vélik, az ekkor születet írásokat már a kezdődő elmebaj szülte; de talán ésszerübb azokhoz csatlakozni, akik szerint sokkal inkább az őrület elleni küzdelem, majd az abban való szándékos és tragikus feloldódás dokumentumairól van szó. Maga Nietzsche úgy nyilatkozott, hogy Az Antikrisztus, melyet tervezett főmüve első kötetének szánt, voltaképpen minden érték átértékelésének summázatát tartalmazza. Reto Winteler véleménye szerint a szakirodalom mindezidáig halogatta annak a kérdésnek a tisztázását, vajon egy többkötetesre tervezett „fömü” első része betöltheti-e az egésznek szánt funkciót, mely ez esetben tehát nem több, mint az értékek teljes körü átértékelése. Ezzel azonban egy alapvető kérdést kerülünk meg: hogy mennyiben tekinthető lezártnak a nietzschei œuvre - hiszen ha mégsem Az Antikrisztus a tetőpont, akkor Nietzsche még a végső szó kimondása előtt összeomlott. ${ }^{319}$

ersten Rangs: - was die Folgen betrifft, so sehe ich jetzt mitunter meine Hand mit einigem Mißtrauen an, weil es mir scheint, daß ich das Schicksal der Menschheit »in der Hand« habe. - Sind Sie zufrieden, daß ich den Schlu $\beta$ mit der Dionysos-Moral gemacht habe? Es fiel mir ein, daß diesen Reihe Begriffe um keinen Preis in diesem Vademecum meiner Philosophie fehlen dürfe. Mit den paar Sätzen über die Griechen darf ich Alles herausfordern, was über sie gesagt ist. - Zum Schluß jene Hammer-Rede aus dem Zarathustra - vielleicht, nach diesem Buche, hörbar... Ich selbst höre sie nicht ohne einen eiskalten Schauder durch den ganzen Leib." kiemelés tölem, L. E.)

${ }^{319}$ Winteler úgy véli, Az Antikrisztussal Nietzsche valóban lezártnak tekintette életművét, melyet így egyúttal a rendszerré-szilárdulás veszélyétől is megóvott. .) Schopenhauer ugyanis úgy véli, hogy a feltételezés, miszerint a világ pusztán fizikai léttel bír, az érzület perverziója, mely a hit világában az Antikrisztus figurájában testesül meg; Nietzsche tehát a schopenhaueri „átokra” utal, mellyel az az Antikrisztus figuráját megbélyegezte. A dionüszoszi filozófia nem más, mint az Antikrisztus pozíciójának ,átértékelése”, az Antikrisztus rehabilitációja. Nietzsche számára Dionüszosz és az örök visszatérés, mint az igenlés legmagasabb formái, voltaképpen szinonímák: mindkettő az ,aszketikus ideállal” való legteljesebb ellenképe, a pozitív annak végtelen negativitása ellenében. Dionüszoszban a tagadás igenléssé oldódik, az igenlés pedig megtestesül. Winteler konklúziója, hogy az örök visszatérés dionüszoszi igenlésének gondolatában Nietzschének végső soron saját életét és életmüvét sikerült a kör végtelenjébe zárnia. Winteler $A$ bálványok alkonyát idézi: „ezzel újra visszaállok arra a talajra, amelyből akarásom, képességem sarjad - én, Dionüszosz filozófus utolsó tanítványa - én, az örök visszatérés tanítója..." (BA 102. o.) Nietzsche jegyzetei alapján nyomon követhető a folyamat, melynek során az átértékelés „fömüvévé” nyilvánítja Az Antikrisztust, és ezzel egyidejüleg a mű alcímét a „Kísérlet a kereszténység kritikájáról” „Átok a kereszténységre” változtatja. (Vö. Reto Winteler: „Nietzsches Antichrist als [ganze] Umwerthung aller Werthe. Bemerkungen zum »Scheitern« eines »Hauptwerks«.” In: Nietzsche-Studien 38. De Gruyter, Berlin, 2009, 229-245. különösen 240-241. o. 18. 1j.) Winteler Jörg Salaquarda remek tanulmányára hivatkozik, melyben Salaquarda a cím-változtatást messzemenő tudatossága mellett érvel; részletesen ismertetve a Schopenhauer Antikrisztus-fogalma és a nietzschei Antikrisztus ,átka” között fennálló hatástörténeti összefüggést. (Ld. Jörg Salaquarda: „Der Antichrist.” In: Nietzsche-Studien 2. De Gruyter, Berlin, 1973, s. 91136.) Ellentétes álláspontot képvisel Thomas H. Brobjer, aki szerint Nietzsche egészen az 1889. január eleji szellemi összeomlásig kitartott a négykötetes Hauptwerk terve mellett. (Ld. Thomas H. Brobjer: „The Place and Role of »Der Antichrist« in Nietzsche's Four Volume Project »Umwerthung aller Werthe«." In: NietzscheStudien 40. De Gruyter, Berlin, 2011. s. 262-273.) 
Az Antikrisztusban Nietzsche elátkozza a kereszténységet, mert az ösztönök tagadásával és a „hanyatlás-értékek” hirdetésével meghonosította a décadence-erkölcs uralmát. A Semmi és a Tagadás ma legyőzni látszik az életakarást, annak helyére a részvét lépett. A megismerhetetlen Ding an Sich és transzcendens világa megszüntethetetlen kétellyel és bizonytalansággal terhelte a modern embert; Nietzsche szerint „Kant sikere pusztán teológus-siker". ${ }^{320}$ Fontos azonban tisztázni: Nietzsche nem a személyes hit, hanem az intézmény ellensége; ${ }^{321}$ a „kereszténységé”, melynek konstitutív elemei a morál és a vallás. Nietzsche mindig is ezeket támadta, nem pedig az alapjában véve szubjektív természetü hitet. A keresztény eszmeiség eredete a zsidóknál keresendő: ők találták ugyanis fel a tagadást mint olyat; velük jelent meg a „ressentiment-morál”. Amint fenyegetve érezték magukat egy nemesebb és erősebb hatalom által, a zsidó nép a legszorosabban vett „,mindenáron való lét” szellemében magukat ettől kezdve amazok ellenében határozták meg. A zsidó-keresztény morál a gyengék, a tömegek, a bosszúszomjasak reakciója - az erőre, a hierarchiára és a felelőtlenségre. Azonban, míg Jahve még hatalmas és önimádó isten volt, a keresztények Istenének képében azonban már nem hatalmas többé, hanem „igazságos”; már semmilyen kapcsolata nincs a természettel. Nietzsche szerint ettől kezdve minden „értékünk” hamis, történelmünk pedig hazugság, mégpedig a leggonoszabb fajtából. A papok kenyere az emberi bűntudat, és azt, hogy mi a bün, ők határozták meg. Nietzsche ugyanis úgy gondolta, hogy az Evangéliumok „,anarchista”, „lázadó” Jézusa nem ugyanaz, mint akit aztán az emberiség Megváltójává kiáltottak ki és kereszthalálra ítéltek. A názáreti Jézus egész egyszerűen lázadó volt, aki a saját „vétkéért” halt meg, áldozata azonban roppant hasznosnak bizonyult az egyházalapítók számára, az önfeláldozás szimbólumaként és az Isten és ember összetartozásának kétségbevonhatatlan bizonyítékaként. De Nietzsche szerint az igazi, az ember-Jézus nem „megváltó” volt, hanem az első „,evangelista”: az első „örömhírhozó”, aki saját életével mutatott példát - ,nem védekezni, nem haragudni, nem tenni felelőssé [...]A keresztényi értékek - nemes értékek: csak mi, szabaddá vált szellemek, mi állítottuk helyre a létező legnagyobb értékellentétet”. ${ }^{322}$ Pál volt a legnagyobb „pénzhamisító”; hiszen Jézus, Isten és ember fia, éppen életével, és nem halálával hirdette az Örömhírt; nevezetesen a „bűn” eltörlését. Nietzsche az imperatív és normatív jellegü hit ellen, a felszabadító kétely nevében emel szót; szerinte ugyanis a meggyőződés és a hazugság közül utóbbi sokkal rosszabb, mert a hazugság legalább nem akar másnak tünni, mint ami. Nem maga a hazugság a rossz, hanem

\footnotetext{
${ }^{320}$ Vö. A 18. o.

${ }^{321}$ Vö. A 47. o. „Istent Istenként utasítjuk el. (...) A »hit« mint imperatívusz a tudomány elleni veto - a gyakorlatban pedig mindenáron való hazugság."

${ }^{322}$ Vö. A 59., ill. 61. o.
} 
ha rossz célból tesszük; a kereszténység pedig az élet ellen hazudik. Törvényt szabni mások számára mindig hazugsággal jár, ám amennyiben az élet növelése a célunk, az szentesíti az eszközt - innen ered a müvészet értéke és a teremtők felelőssége. ${ }^{323}$

Utoljára hagytuk a számvetést azzal a problémával, amely tulajdonképpen Nietzsche egész életét döntően befolyásolta: a Wagnerrel való konfliktust. Nietzsche számára ő volt a legnagyobb motiváció: neki akart megfelelni, az ő elismerésére vágyott, ellene küzdött, töle szenvedett. ${ }^{324}$ Ismert történet, ahogyan Wagner és Cosima manipulálták és kihasználták az udvartartásukba tartozókat; a tribscheni kúria állítólag szinte vallási szentély volt. A wagneriánusok a szó legszorosabb értelmében istenítették a Mestert, aki mindent meg is tett e szép látszat fenntartásáért; Cosima pedig, a „főpapnői” teendők ellátása mellett, ahogyan ma mondanánk, személyi titkár és kampányfőnök volt egy személyben. Házastársi viszonyuk ugyan nem volt zökkenőmentes, de az asszony, kiváló politikus lévén, mindig tudta, meddig mehet el. Az antiszemita propagandával kiegészülve a Wagner-kör szinte szekta-jelleget öltött. $^{325}$ Mindez az Ünnepi Játékokban a lehető legplasztikusabban manifesztálódott; Bayreuth csak a bigott „hívők” gyomrát nem feküdte meg. Nietzschét mindezek mellett mélységesen felháborítja Wagner hirtelen jött kereszténysége, mely számára még a wagneri életmű maradék hitelességét is eltörölte. Wagnert meglepő módon épp ekkortájt kezdte oly mértékben aggasztani Nietzsche testi-lelki állapota, melynek hátterében a „krónikus onanizálás” bűnös és sajnálatraméltó gyakorlatát vélte megbújni, hogy „gyanújáról” levélben számolt be Dr. Otto Eisernek, a filozófus orvosának, aki 1878 áprilisában ismertette a filozófussal a wagneri „diagnózist” - Nietzsche nem sokkal ezután Capri szigetének egyik tengerparti barlangjában, a hajnalpír fényénél akart öngyilkos lenni. De megküzdött saját életéért; és a következő négy évben megszületett a „szabad szellem-trilógia”, Wagner

\footnotetext{
${ }^{323}$ Mihailo Durić elsősorban rendszerkritikaként értelmezi a nietzschei filozófiát, hiszen a rendszeralkotás a „valóság” abszolút megismerhetőségének lehetőségét vesz alapul, ezzel pedig erőszakot tesz mind a gondolkodáson, mind az életen. Nietzsche kifejezetten kerüli a rendszerben való gondolkodást, írásainak nyelvezete maga is metaforikus, perspektivikus, változékony; igyekszik fenntartani megfoghatatlan és kimondhatatlan rejtély-karakterét. Gyanítjuk ugyan, hogy a tragikus gondolat, a korszerütlenség, a szabad szellem, a vidám tudomány, a hatalomakarás és az örök visszatérés gondolata mélyén egyetlen alapgondolat rejlik, de épp ez, a közös „,eredet” maradt mindig kimondatlan. Nietzsche így próbál rábírni bennünket, hogy merjünk gondolkodni; hogy ne várjunk a gondolat „érkezésére”, hanem gondoljuk el mi magunk. (Vö. Mihailo Durić: „Nietzsche filozófiaművészete.” In: EX-Symposion. 1994. Nietzsche-különszám. 63-71. o.) Nietzsche filozófiája teljes mértékben gyakorlati: semmit nem értünk belőle, ha csak elhisszük: alkalmaznunk kell, méghozzá saját magunkon. Ez azonban nyilvánvalóan veszélyes, identitásunkat fenyegető, „dionüszoszi” feladat.

${ }^{324}$ Vö. Nietzsche (2008) 91. o. „Levél Richard Wagnernek.” (1876. május 21.)

${ }^{325}$ Vö. WE „Első utóirat.”, illetve Joachim Köhler: Friedrich Nietzsche és Cosima Wagner: az alávetettség iskolája. Ford. Romhányi Török Gábor. Holnap, Bp., 2005. 44-116. o.
} 
halálának napján pedig befejezi a Zarathustra első részét. ${ }^{326}$ A Wagner esetében Nietzsche azzal vádolja a Mestert, hogy ,a zenét megfosztotta világdicsőítő, igenlő jellegétől”, őt pedig „megbetegítette” - de, mint mondja, mindezen vádak valójában a „német szellem” ellen szólnak. ${ }^{327}$ Wagner alkalmazta színpadra Schopenhauer filozófiáját, mely „az etikus légkör, a fausti illat, a kereszt, a halál és a sírbolt" ${ }^{\dagger 28}$ párás és beteges pesszimizmusát hozta magával. De Wagner egyszersmind Hegel örökösének is tekinthető; hiszen az ,abszolút zene”: a hegeli „abszolút szellem”, ,a zene, mint »eszme«”. ${ }^{329}$ A mü Epilógusából idézünk most egy hosszabb részt; mivel e helyt nem áll módunkban, és talán témánk szempontjából nem is szükséges a részletes elemzés:

Megadom az én modernség-fogalmamat. - Minden korszak erejének méréséhez az a mérték is hozzátartozik, hogy milyen erényeket engedélyeznek és milyeneket tiltanak benne. Vagy a felszárnyaló élet erényei szerepelnek benne: ebben az esetben a végsőkig ellenáll a hanyatló élet erényeinek. Vagy maga a hanyatló élet ez a korszak - és akkor szüksége van a hanyatlás-erényekre is, akkor gyülöl mindent, ami a teljességböl származik, és az erők túláradó bőségével igazolja magát. [...] Az értékek optikájában mindkét ellentétforma szükségszerü: látásmódok ezek, amelyek hozzáférhetetlenek okok és cáfolatok számára. A kereszténység nem cáfolható, ahogy nem cáfolható egy szembetegség sem. A tudós agyalágyultság tetőpontja az volt, amikor a pesszimizmussal úgy küzdöttek, mintha az filozófia lett volna. Az ,igaz” és „nem igaz” fogalmainak ebben az optikában, szerintem, nincs értelmük. - Ezzel szemben, ami ellen védeni kell magunkat, az a hamisság, az ösztön-villásnyelvüség, amely ezeket az ellentéteket nem akarja ellentétnek érezni: amilyen például Wagner akarata volt, aki az ilyen hamisságokban a kis mester rangjára tett szert. [...] A megváltás igényének, minden keresztény igények kvintesszenciájának az efféle paprikajancsikhoz semmi köze: ez a décadence legtisztességesebb kifejezési formája, a reá mondott legmeggyőződésesebb, legfájdalmasabb Igen emelkedett szimbólumokban és prédikátumokban. A keresztény meg akar szabadulni önmagától. Le moi est toujours haissable - Az én mindig gyülöletes (Pascal - a ford.). - És megfordítva: az előkelő morál, az uralkodó morál egy önmagára való diadalittas Igent-mondásban gyökerezik. Önigenlés ez, az élet önimádata, tehát emelkedett szimbólumokra és prédikátumokra van szüksége, de csak azért, „mert túlságosan is csordultig telt a szíve”. Az egész szép, az egész nagy müvészet ide tartozik: háládatosság mindkettő, lényege szerint. [...] Ám tudásunk és akaratunk ellenére mindannyian hordozunk a testünkben szinte egymást kizáró forrásokból származó értékeket, szavakat, képleteket és morálokat - fiziológiailag szemlélve hamisak vagyunk... Mivel kezdődne a modern lélek diagnosztikája? Határozott bemetszéssel ezen ösztön-ellentmondásosságba, az ellentét-értékek elszigetelésével,

\footnotetext{
${ }^{326}$ Vö. Köhler (2005) 120-184. o.

${ }^{327}$ Vö. EH 115. o.

${ }^{328}$ Vö. BVN-1868,591 „Brief an Erwin Rohde.” („Mir behagt an Wagner, was mir an Schopenhauer behagt, die ethische Luft, der faustische Duft, Kreuz, Tod und Gruft etc.”)

${ }^{329}$ Vö. WE 10. §
} 
legtanulságosabb esetük élveboncolásával. - A Wagner-ügy szerencsés eset a filozófusoknak -, ezt az írást, tudjátok meg, a háládatosság ihlette... ${ }^{330}$

Az utolsó torinói hónapokban Nietzsche, levelei alapján, kifejezetten elégedettnek, olykor egészen eksztatikusnak tünik. Ugyanakkor a levelek és naplójegyzetek stílusán megfigyelhető, ahogyan az őrület lépésről-lépésre átveszi az uralmat Nietzsche felett. Már magában az a tény, hogy 1888-ban 263 (!) levelet ír, elszomorító. Önmagát ismételve mesél boldog-boldogtalannak torinói csodás napjairól (különösen nagyra értékeli az aszfaltot és az egyszerre olcsó és laktató ételeket), műveinek skandináviai és tengerentúli sikereiröl, minden érték átértékelésének isteni feladatáról. Aztán november-december táján már egyre több a megalománia, a szürrealitás; feltűnnek az első „isteni” aláírások. 1889. január 3-án Nietzsche lakása közelében, a Piazza Carlo Albertón meglát egy kocsist, amint a lovát ütlegeli: könnyezve borul az állat nyakába, két rendőr ráncigálja el. A következő napokból származnak az ún. „örületcédulák” [Wahnsinnszettel], melyeket már nem Friedrich Nietzsche ír: „Megfeszítettként” börtönbe vetné a pápát és Olaszország királyát, Bismarckot és Vilmos császárt felakasztaná, az antiszemitákat pedig agyonlövetné; „Dionüszoszként” teremtőket és új világokat teremtett és istenként él az emberek között. Szállásadói beszámolói alapján szobájába zárkózva szétszaggatta leveleit, bankjegyeit; meztelenül, delíriumban énekelt és táncolt, zongorája billentyüit verte és félrebeszélt. Időközben Jacob Burchardt és Franz Overbeck, Nietzsche legrégibb barátai, kézhez kapták a „cédulákat”; Overbeck Torinóba utazott, és Nietzschét a bázeli pszichiátriára vitte. Innen anyja kérésére a jénai klinikára szállították át, majd 1890 májusától 1897 húsvétjáig ő maga ápolta fiát naumburgi otthonukban. Ekkor, Franziska Nietzsche halálakor lépett színre Elisabeth, aki Weimarba vitte bátyját, és a Nietzsche-Archiv-ban maga az agonizáló zseni lett az egyik - igaz, csak a kiválasztottak által látogatható - legfőbb kiállítási tárgy. A szerető nővér némi „átcsoportosítás” után kiszolgáltatta a nietzschei életművet a náci propagandának; Hitler többször járt az archívumban, sőt még Elisabeth 1935-ös temetésén is részt vett. Nietzsche végül 1900. augusztus 25 -én tért meg utolsó, örökkévaló magányába. ${ }^{331}$

Rengeteg kutatás foglalkozik a kórtörténet pontos rekonstrukciójával; szóba kerül persze a szifilisz, a diftéria és a családi hajlam; a pszichiátriai jegyzőkönyvekben pedig atípusos progresszív bénulás (paralysis progressiva) szerepel. A legújabb kutatások szerint

\footnotetext{
${ }^{330}$ WE „Epilógus.”

${ }^{331}$ Vö. J. R. Hollingdale: „Rövid Nietzsche-életrajz.” In: EX-Symposion. Nietzsche-különszám. 1994. 2-9. o.
} 
azonban legalább hat különböző diagnózis jöhet szóba Nietzsche mentális zavara kapcsán, nevezetesen 1. a már említett általános és lefolyású bénulás, 2. bipoláris viselkedészavar, majd azt követő vaszkuláris demencia (ismétlödő szélütések következtében), 3. örökletes frontotemporális demencia (elbutulás), 4. agydaganat, 5. Cadasil-szindróma (monogénes stroke-szondróma), illetve 6. Melas-szindróma (mitochondriális DNS-mutácó következtében alakul ki). Tényi Tamás szerint a legvalószínűbb a frontotemporális demencia egyik speciális esete, az ún. Pick-kór, melyet a közösségi magatartás zavara, téveszmék megjelenése; a kór pár éven belül halálhoz vezet. Szintén Tényi számol be Carl Gustav Jung 1934. májusi szemináriumairól, ahol a híres pszichoanalitikus Zarathustrát Nietzsche archetipikus karaktereként értelmezte. Az ülések a hallgatók jegyzetei alapján a zürichi Pszichológus Klubban, szerdánként tizenegy és délután egy óra között, a témához illő, kellőképpen misztikus és ezoterikus légkörben zajlottak: a résztvevők névvel ellátott székeken ültek, minden alkalommal egy-egy Zarathustra-részt olvastak fel és vitattak meg, ezt követte a professzor előadása. Jung úgy vélte, Nietzsche 1889-es összeomlása nem más volt, mint ,az archetípus általi elnyeletés”. ${ }^{332}$ De kiféle-miféle is volt akkor ez a „Nietzsche-Zarathustra”? „látnok, akaratnak és teremtésnek embere, maga a jövő és híd a jövőbe - és, ó, jaj, egyszersmind nyomorék is e hídon: ez mind Zarathustra". ${ }^{333}$ Nietzsche 1888. december 6-án így ír Köselitznek: „néha azért nem látom be, miért is kellene életem tragikus katasztrófáját, mely az »Ecce«-vel kezdődik, ennyire felgyorsítanom!"334 Pontosan tudja, hogy annak, amit mondott - vagy inkább tett -, tragikus következményei lesznek reputációjára nézve. De akkor mi volt a célja megdöbbentően narcisztikus és megalomán dicshimnusz-áradatnak, melyet saját magáról zengett az Ecce homo-ban - természetesen nem vonva kétségbe, hogy mindezt komolyan is gondolta? Ez volt utolsó, végsőkig elkeseredett kísérlete, hogy felhívja a figyelmet a modernizmus egyre mélyülő válságára és a szemléletváltás szükségességére. Nietzsche nem egyszerüen a modernitás, az erkölcsi világrend, a kereszténység vagy a metafizikus gondolkodás kritikusa volt; ő a hazug optimizmust és a gyáva pesszimizmust, a passzív nihilizmust állította „örökké visszatérő” kihívás elé.

A nietzschei gondolkodás épp azért tekinthető radikális metafizika-kritikának, mert reprezentáció-kritikára épül, vagyis az értékek értékének problémáját, az egyáltalában vett

\footnotetext{
${ }^{332}$ Vö. Tényi Tamás: „The madness of Dionysus -- six hypotheses on the illness of Nietzsche.” In: Psychiatria Hungarica. 2012/6. 27. évf. 420-425. o., valamint U. ő: Nietzsche és a pszichológia. Pécs, PTE, 2007. 77-114. o. ${ }^{333}$ Z II: 1774-75. „A megváltásról.”

${ }^{334}$ Nietzsche (2008) 252. o.
} 
metafizikakritika alapkérdését veti fel. ${ }^{335}$ Nézetem szerint az általunk ,aktív differenciaként” aposztrofált operatív és heterogén erő lehet egy ilyen, alapokat megrengető kritika egyedüli alapja. Nietzsche volt az, aki ráébredt, hogy az ,igazság utáni kutatás” valódi neve a „Semmi elől való menekülés" - a metafizika mélyén a nihilizmus erői munkálkodnak, ennek az állapotnak pedig csak úgy lehet véget vetni, ha kihasználjuk a minden erő alapját képező hatalomakarás ösztönét, mely önmaga kiteljesítésére készteti az adott eröt. Ez azonban a metafizika/nihilizmus esetében öngyilkossággal egyenlö, amennyiben a Semmi akarásának végletekig hajtását jelenti - méghozzá az „átkristályosítás”, az átalakítás értelmében, melynek eredménye „a dionüszoszi átértékelés a fájdalomból az örömbe." ${ }^{336}$ Nietzsche ebben az értelemben joggal hasonlíthatja magát az „aranycsinálóhoz”; az alkímia „tudományos” értelemben - metafizikai, „opusmagnum”-jellegü variánsaitól most tekintsünk el - a következő tevékenységeket jelentette: arany vagy ezüst előállítása közönséges fémböl, az örök élet elixírjének felfedezése, vagy mesterséges élet létrehozása. Nietzsche pedig a „szabad szellem”, az Übermensch, a hatalom akarása és az örök visszatérés neve alatt alkímiát végzett.

Fontosnak tartjuk ismételten leszögezni: nem állítjuk, hogy Nietzschének sikerült meghaladnia a metafizikát; pusztán amellett érvelünk, hogy a nietzschei filozófia a metafizika-kritikát végső határáig vitte, és ezzel a metafizikus gondolkodásmódot, és az arra épülő erkölcsi világrendet jellemző általános élet-tagadást radikális igenléssé kristályosította át.A koncepció lényege nézetünk szerint tehát a reprezentáció-kritika: Nietzsche nem feloldani akarja a különbséget egy végső, mindent kiegyenlítő azonosságban, hanem ellenkezőleg, saját maximumáig viszi, vagyis aktivizálja. Heidegger kritikáját alapvetően azért tartjuk problematikusnak, mert úgy véljük: félreértette Nietzsche szándékát; aki még őelőtte felismerte, hogy minden metafizikai gondolkodás alapvonása az ontológiai differencia elfelejtése. De ő Heideggernél is távolabb merészkedett, rájött ugyanis, hogy ez a „felejtés” nem magának a differenciának a természetes velejárója, ahogyan azt Heidegger állította, ${ }^{337}$ hanem, mint a metafizikai vigasz lényege, egy átfogóbb perspektívából vizsgálva a Semmiről való megfeledkezés akarása, mely a nihilizmus alaptendenciája, és amely végsőkig fokozva magának a Semminek az akarásához vezet. Így tehát, paradox módon, épp az ontológiai

\footnotetext{
335 Vö. Deleuze (1999) 13-23. o.

${ }^{336}$ Deleuze (1999) 268. o.

${ }^{337}$ Martin Heidegger: Identität und Differenz. Günther Neske Verlag, Pfullingen, 1978. s. 25. „Wir sprechen von der Differenz zwischen dem Sein und dem Seienden. Der Schritt zurück geht vom Ungedachten, von der Differenz als solcher, in das zu-Denkende. Das ist die Vergessenheit der Differenz. Die hier zu denkende Vergessenheit ist die von der $\Lambda \eta \dot{\vartheta}$ (líthi/Verbergung) her gedachte Verhüllung der Differenz als solcher, welche Verhüllung ihrerseits sich anfänglich entzogen hat. Die Vergessenheit gehört zur Differenz, weil diese jener zugehört. Die Vergessenheit befällt nicht erst die Differenz nachträglich zufolge einer Vergeßlichkeit des menschlichen Denkens."
} 
differencia aktivizálása jelentheti egyedül a nihilizmus kiteljesítését, végül pedig önfelszámolását. S hogy mi marad utána? Semmi, ami bizonyos vagy befejezett, csak az örök keletkezés és alakulás, és ezáltal a hatalomakarás kiteljesítésének egy újfajta, kockázatos, a Semmivel, a metafizikai vigasz nemlétezésével szembenéző, dionüszoszi értelemben akaróteremtő, tragikus lehetősége.

A torinói összeomlás margójára: a tragikus történések elött pár hónappal, még bizonyosan tiszta tudattal Nietzsche ezt írja Reinhardt von Seydlitznek: „tegnap egy képre gondoltam, moralité larmoyant-tal, ${ }^{338}$ Diderot-val szólva. Téli táj. Egy öreg kocsis, a legbrutálisabb cinizmussal az arcán, amely keményebb még a rideg télnél is, levizeli a saját lovát. A ló, ez a szegény, védtelen teremtés pedig hálásan, nagyon hálásan néz."339

\footnotetext{
${ }^{338}$ könnyes moralitás

${ }^{339}$ Nietzsche (2008) 204. o.
} 


\section{II. rész. Metafizika és kritika}

\section{1. Heidegger Nietzsche-kritikája}

Mielött továbbmennénk, és amellett kezdenénk érvelni, hogy az általunk a nietzschei filozófia mélyén a kezdetektől munkálkodni vélt „aktív különbség” gondolata valójában az általában vett metafizika-kritika, sőt, a par excellence kritikai attitüd lehető legteljesebb megnyilvánulása, megkerülhetetlennek tartjuk Heideggermetafizikával mint olyannal, illetve a metafizika meghaladásának nietzschei kísérletével kapcsolatos kritikájának tárgyalását. Meggyőződésünk ugyanis, hogy ennek hiányában maguk az általunk vizsgálni kívánt problémák sem mutatkozhatnak meg voltaképpeni mélységükben.

\section{1. a. Az „ontológiai differencia”}

Heidegger szerint a nyugati filozófiában a „lét” kifejezés, egészen a görögöktől kezdve a legáltalánosabb, ezáltal definiálhatatlan fogalomként van használatban; Arisztotelész óta a létet az „analógia egységeként” értjük, anélkül, hogy problematizálnánk ezt az egységet. Definiálhatatlannak tekintjük, holott épp a meghatározás lehetősége tenné indokolttá a lét értelmére irányuló kérdezést. Az, hogy magától értetődően használjuk a létigét, az eleve adott létmegértés látszatával fedi el az eleve adott létfelejtés tényét. Egyrészt tehát szükséges a lét értelmére vonatkozó kérdés újrafeltevése, másrészt ez az újrafeltevés másként-feltevés, helyesen-feltevés kell, hogy legyen. Hogyan épüljön föl egy ilyen kérdés? Az általában vett kérdezés alapstruktúrája a „kérdezett-kikérdezett-rákérdezett” hármasság, melyben a kérdés mint olyan kérdésként tétetik fel. A triád első tagja, a „kérdezett”, voltaképpen a keresett dolgot nevezi meg, ez esetünkben a megértettként tételezett lét; a „kikérdezett” a létező, melyet „éte felől kérdezünk ki”, a „rákérdezett” pedig a lét értelme, melyre kérdezésünk mint keresés irányul. A „kikérdezett” létezőnek „példaszerư” létezőnek kell lennie, ugyanakkor rendelkeznie kell a „kérdezés létlehetőségével”, vagyis amely létében már eleve viszonyul önnön létéhez; ez a létező maga az emberi ittlét, a ,jelenvalólét”, a Dasein. A létre irányuló kérdés feltevésének előfeltétele tehát a Dasein meghatározása a maga létében, mely már eleve „átlagos és homályos létmegértésben” van. De mi indokolja a lét ontológiai kitüntetettségét? Ahhoz, hogy egy tudományt megalapozzunk, először is tisztázni kell a fogalmi keretet, 
melyen belül ezek az alapok elgondolhatók, így tehát elsőként az „,alapfogalmakat” kell vizsgálnunk. A filozófia tekintetében ez elsődlegesen a létező, mint a kutatás által kijelölt, lehető legszabatosabban értett tárgyterület értelmezését jelenti. Az ontológiai kérdésnek tehát meg kell előznie bármely, a létezőről tehető pozitív kijelentést, amennyiben arra kérdez rá, hogy mi van egyáltalán. Mi következik mindebből? Hogy a lét ontológiailag és ontikusan is elsődleges, „minthogy létében önnön létére megy ki a játék”. ${ }^{340}$ Az egzisztencia a jelenvalólét [Dasein] lehetősége az önmaga-létre, mint létmegértő jelenvalólétre; a létező tehát csak a létmegértésben van tulajdonképpeniként („faktikus lét”). Heidegger tehát úgy kívánja vizsgálni a jelenvalólétet, ahogyan az van - ahogyan ő fogalmaz, ,átlagos mindennapiságában", ${ }^{341}$ melyben radikálisan időbeliként ${ }^{342}$ van, és melyben így maga az idő a „létmegértés horizontja” ${ }^{\text {"343 }}$ A jelenvalólét mint egzisztencia, azaz létmegértő létezés, ennélfogva történeti létként tud önmagáról, így a létkérdésnek magának is történetiként kell artikulálódnia, és ekként kell értenie saját magát. ${ }^{344}$ A jelenvalólét egzisztenciális analitikájának így egyszersmind a ,fakticitás hermeneutikáját” is tartalmaznia kell. ${ }^{345}$

Heidegger célja tehát a lét értelmére irányuló kérdés újrafeltevése, ennek előfeltétele pedig a kérdés értelmének megértése, valamint az időnek mint a létmegértés horizontjának értelmezése; mindez azonban még nem ontológia, pusztán annak megalapozása, pre-ontológia lehet. Heidegger az ontológiatörténet destrukcióját, vagyis alapfogalmainak eredetvizsgálatát tüzi ki célul, melyet azonban nem rombolásként, hanem pozitíve, az alapfogalmak mögött megbúvó, elfeledett, „,eredendő tapasztalatok” feltárásaként értendő. Nézete szerint ugyanis a nyugati metafizika egész tradíciójában Kant volt „az első és az egyetlen”, aki egyáltalán

\footnotetext{
${ }^{340}$ LI 4. $\S$

${ }^{341}$ LI 5. $\S$

${ }^{342}$ A jelenvalólét analitikájának során az „időbeliséget” nem az „időtlenség” ellentéteként, hanem mint azt létében már eleve pozitívan meghatározó értelemben kell értenünk; ezen alapvetőbb értelem számára Heidegger bevezeti a „temporalitás” terminust.

${ }^{343}$ U. ott

${ }^{344}$ Szükségesnek tartjuk emlékeztetni az „egzisztencia” másik nagy filozófusának, Jaspersnek a heideggerihez első pillantásra hasonló, ám lényegét tekintve mégis jelentősen különböző egzisztencia-fogalmára. Mindketten hatalmas jelentőséget tulajdonítanak az Élet általuk egzisztenciálisan, egyfajta létre irányuló szenvedélyes keresésként értett fogalmának, valójában azonban éppen itt érhető tetten a kétféle interpretáció lényegi különbsége. Jaspers pszichologizáló olvasatában Nietzschét a szenvedélye teszi alkalmassá arra, hogy felfedje a Létet, míg Heideggernél a Lét maga az, ami ezen szenvedély révén mutatkozhat meg. Jaspers „egzisztenciája” [Existenz] minden partikuláris létezés lehetőségfeltétele, míg a heideggeri Dasein, az emberi egzisztencia a hely, ahol a Lét feltárulkozhat. Heidegger számára így a metafizika, vagyis a Dasein egzisztenciális analízise csak az ontológia afféle propedeutikája lehet. (Vö. Karl Jaspers: Nietzsche: Einführung in das Verständnis seines Philosophierens. De Gruyter, Berlin - Leipzig, 1974, s. 184-212., illetve Richard Lowell Howey: Heidegger and Jaspers on Nietzsche. Martinus Nijhoff, The Hague, 1973. p. 1-11.)

${ }^{345}$ Vö. LI 1-6. §, illetve Martin Heidegger: „Bevezetés a »Mi a metafiziká?«-hoz.” Ford. Vajda Mihály. In: Uő: „,... költöien lakozik az ember ...”Válogatott irások. Szerk. Pongrácz Tibor, Ford. Bacsó Béla et al. T-Twins Pompeji, Budapest - Szeged, 1994a, 180-181. o.
} 
problémává emelte a létező temporalitásának kérdését, azonban végül ő is visszarettent a lehetséges következményektől. Heidegger A tiszta ész kritikáját metafizikai alapvetésként, a fundamentálontológia alapműveként értelmezi, és a transzcendentális sematizmust helyezi az egész kanti rendszer központi helyére. Ennek ellenére meggyőződése, hogy a kanti sematizmus-tan kitért a létkérdés feltevése, illetve a jelenvalólét ontológiájának végiggondolása elől, ebből eredően pedig elmulasztja az idő-probléma temporalitásproblémaként való vizsgálatát. Azáltal ugyanis, hogy a descartes-i cogitót alapvetésként kezeli, Kant eleve belül marad a vulgáris időfelfogáson, mely az időt szubjektivitásként érti. Heidegger értelmezésében A tiszta ész kritikája az emberi végességet a metafizika mint olyan alapproblémájaként mutatja fel; hiszen az ember tiszta érzékiség, így az érzéki szemléleten alapuló emberi megismerés fakultása, az ész is érzéki. Egészen pontosan: „csak azért »rendelkezhet« az ember mint véges lény transzcendentális, azaz metafizikai értelemben véve a testével, mert a transzcendencia mint olyana priori érzéki." ${ }^{346}$ A sematizmus mint képalkotás Heidegger olvasatában a tiszta értelmi fogalmak „megérzékítése”, melynek révén a képzelőerő kijelöli a „transzcendencia horizontját”. ${ }^{347}$ Mivel pedig a sémák Kantnál „a priori”, vagy másképpen „transzcendentális időmeghatározások”, ${ }^{348}$ a séma-képzés, mint a transzcendenciát az ember számára megnyitó esemény radikálisan időbeli. ${ }^{349}$

Heidegger tehát úgy véli, a metafizika, mely lényegét tekintve ontológiaként lepleződött le, tendenciózusan elmulasztja voltaképpeni feladatát, mely „a lét elhatárolása a létezőtől és magának a létnek az explikálása" ${ }^{350}$ volna. A létkérdésnek mint az ontológia alapkérdésének tisztázásakor a fentiek értelmében tehát a voltaképpeniség mint „hogyan-lét” vizsgálatát kell elvégeznünk, ez pedig a fenomenológia feladata. A fenomén mint az elrejtettségben lévő „önmagán-megmutatkozása”, és a logosz mint „láttatás”, „felfognihagyás” funkcióit egyesítve a fenomenológiaként értett ontológia feladata „önmagából láttatni azt, ami önmagát megmutatja, úgy, amint saját magából megmutatkozik"351. De mi az, ami lényegszerűen elrejtett, és amelynek ez az elrejtettsége minden el-nem-rejtettség alapját és értelmét adja? Ez a létező léte, mely fenoménként megmutatkozó és logoszként megérthető. A

\footnotetext{
${ }^{346}$ Martin Heidegger: Kant és a metafizika problémája. (ford. Ábrahám Zoltán, Menyes Csaba) Osiris/Gond, Bp., 2000, 215. o. (31. §)

${ }^{347}$ U. ott. 124. o. (19. §)

${ }^{348}$ Ld. TÉK 173., illetve 175. o.

349 Vö. Heidegger (2000) 120-143. o. illetve 249. o.: „A metafizika kanti alapvetése a transzcendentális képzelőerőhöz vezetett. Ez a két törzs, az érzékiség és az értelem gyökere. Mint ilyen teszi lehetővé az ontológiai szintézis eredendő egységét. De ez a gyökér az eredendő időben gyökerezik. Az alapvetésben láthatóvá váló eredendő alap: az idő."

${ }^{350}$ LI 7. $\S$

${ }^{351}$ LI 7. C) $\S$
} 
róla való elfeledkezés, a létező létének és eme lét értelmének az elrejtettségben-hagyása a nyugati metafizika kétezer éve tartó történelmének alaptörténése, melyet Heidegger az ontológiai differencia elfelejtéseként azonosít. ${ }^{352}$

„Fenntartjuk a létezőt és egyúttal megőrizzük a Léthez való viszonyunkat. Egyedül így lehet a létező egésze az, ami megtart és aminél elidőzünk. Ezt jelenti, mikor azt mondjuk: a létező és a Lét megkülönböztetésében állunk. Egy ilyen megkülönböztetés fenntartja a Léttel való kapcsolatot, és elősegíti a létezővel valót. Anélkül érvényesül, hogy tudatában lenne. Ezért olyan megkülönböztetésnek tünik, melynek különbségei semmitől nem különböznek, melyben »nincs« megkülönböztető, és amelynek területe sincs, nemhogy tapasztalata. Szinte igaza is lehetne annak, aki azt feltételezi, hogy azzal, amit a Lét és a létező közti »megkülönböztetésnek« nevezünk, pusztán kitaláltunk, feltaláltunk valamit, ami »nincs«, és amelynek nem is szükséges »lennie«. De elég egy pillantást vetnünk a metafizikára és annak történetére, és máris másképpen látjuk. A létező és a Lét különbsége akként mutatkozik meg, amiből minden metafizika ered, és az eredésbe mint olyanba ugyanakkor bele is menekül; olyanként, mint amit maga után, hatókörén kívül hagy akként, mint amit már soha többé nem gondol el és amit nem is kell elgondolnia. A létező és a Lét megkülönböztetése teszi lehetővé a létező minden megnevezését, tapasztalását és megragadását mint olyat. ${ }^{\text {,353 }}$

Míg a Lét és idő az emberi jelenvalólét analízisétől halad a Lét megértése felé, az Azonosság és differencia magát az ember és Lét közti relációt problematizálja, tehát nem annak elemeit, hanem magát a viszonyt mint viszonyt vizsgálja. Míg Parmenidésznél még a Lét volt az azonosság felől elgondolva, a metafizika őt követő tradíciójában már az azonosság volt az, ami csak a Lét eredendő egysége révén volt elgondolható. (Az azonosság, mely egy adott dolog önmagával való egységét jelenti, a metafizikus gondolkodás első számú problémájaként artikulálódik, ennek iskolapéldája Plótinosz és Leibniz. Előbbinél az Egy végső realitása megelőzi a Lét realitását, ${ }^{354}$ az összes létező léte abból származik; Leibniz pedig Monadológiájában az azonosságot két dolog közti különbség teljes hiányában, a

\footnotetext{
${ }^{352}$ Vö. LI 6-7. § Ez voltaképpen Heidegger sematizmus-kritikájának központi gondolata is. Kant ugyanis szerinte megmaradt a fenomén vulgáris fogalmánál (jelenség), mely azonban csak a létezőt mint általában vett létezőt mutatja fel, és nem reflektál annak tulajdonképpeni létére, mely jelenvalólétként csak a létmegértő önmagát-felfedésben van.

${ }^{353} \mathrm{NI}$ II:207-208., bővebben NI II:203-213.

${ }^{354}$ Vö. Plótinosz: Az Egyröl, a szellemröl és a lélekröl - válogatott irások. Ford. Horváth Judit, Perczel István. Európa, Bp., 1986, V. 1, 223-240. o.
} 
„láthatatlanok” azonosságaként definiálja, mint az egység és egyediség elsődleges jelentését. ${ }^{355}$ ) Heidegger számára ami ,azonos”, azaz az ember és a Lét, az csak az azonosságnak magának a természete felől gondolható el. Kétségbe vonja, hogy az azonosság valóban a gondolkodás alapelve; úgy véli, elsőként azt kell tisztáznunk, mit is értünk „azonosság” alatt. A gondolkodás alapelve a Lét alapelve kell, hogy legyen, a princípium tehát a következő: minden dolog lényegéhez tartozik az önmagával való azonosság, mely a létező Létének alapkaraktere. Ahelyett, hogy a létezőt faggatná a Lét felől, Heidegger a létező és a Lét különbségét, az ontológiai differencia gondolatára összpontosít. Ez a differencia elfeledett, ezért el kell gondolni - hogy legyen. A Létet mint azonosságot tételező metafizikai gondolkodásban maga a par excellence differencia az, ami elfeledett, tehát nincs, és amit el kell gondolnunk - hogy legyen. A differencia a „túláradás” [Überkommnis] és a „megérkezés” [Ankunft] különbsége, a hely, ahol a Lét túláradása és a létezőbe való megérkezése egymáshoz közelít és egyszersmind egymástól távolodik. Ebben a köztességben válik lehetővé bármely lét vagy történés. Heidegger számára a végső kérdés, hogy vajon nem tartozik-e ez a különbség a Lét mint olyan lényegéhez, annak kezdetétől egészen beteljesüléséig? Ha így lenne, a metafizika alapfogalmai érvényüket vesztenék, mivel azok csak azt képesek megnevezni, ami különbözik, nem pedig magát a különbséget. ${ }^{356}$ „Heidegger a következő kérdéssel hagy magunkra bennünket: vajon a nyugati nyelvek struktúrája eredendően metafizikai, melynek révén már eleve ontoteológiai jellegüek, vagy magukban rejtik a gondolkodás másfajta lehetőségeit is?"357

Heidegger szerint bármely, a különbségről való gondolkodásnak számot kell vetnie Hegellel és a dialektikával. Hegelnél a gondolkodás dialektikus mozgása a lét alapvető dialektikáján alapul; így a történeti jelleg nála szigorúan spekulatív módon értendő. A kettejük gondolkodása közti alapvető különbségeket Heidegger három pontban foglalja össze. 1. a gondolkodás tárgya Hegelnél a Létnek az abszolút létezőként elgondolt létezőhöz való viszonya, az „eszme” mint abszolút fogalom; Heideggernél pedig az Ugyanaz, vagyis a Lét, méghozzá a létezőtől való különbségében: a differenciamint differencia. 2. A gondolkodás történetéhez való viszonyában Hegelt az ,abszolút szellem” eszméje határozza meg, melyhez minden létező, gondolat és gondolkodó pozíciója meghatározható, egy dialektikus folyamat

\footnotetext{
${ }^{355}$ Vö. G. W. Leibniz: „Monadológia.” 7-8. § In: U. ő: Válogatott filozófiai irásai. Ford. Endreffy Zoltán et al. Európa, Bp., 1986.

${ }^{356}$ Vö. Joan Stambaugh: „Introduction.” In: Martin Heidegger: Identity and Difference. Trans. Joan Stambaugh. Harper \& Row, New York - Evanston - London, 1969. pp. 8-18.

${ }^{357}$ Stambaugh (1969) p. 18. „Heidegger leaves us with the question: do our Western languages have an intrinsic metaphysical structure so that they are forever destined to be ontotheo-logical in their nature or do they harbor other possibilities of thinking?"
} 
fázisaként. Heidegger ezzel szemben azután kutat, ami még nem lett elgondolva, ami éppen elrejtettségében, elfeledettségében az, ami: a gondolkodás lényege. 3. Hegel a „megszüntetvemegőrzés” módján viszonyul a filozófiai tradícióhoz, míg Heidegger „visszalép egyet”. 358 Heidegger az elfeledett, elrejtett differenciáról beszél, „kísérleti jelleggel és elkerülhetetlenül a tradíció nyelvén. A Lét és a létező közti különbségröl beszélünk. A visszalépés attól lép el, ami elgondolatlan, a differenciától mint olyantól, a felé, ami révén gondolkodunk. Ez a különbség elfelejtése. Az itt elgondolandó felejtés a differencia mint olyan elfedése, az

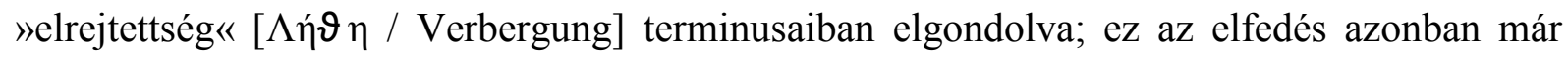
kezdettől fogva visszavonta magát. A felejtés a differenciához tartozik, mert a differencia a felejtéshez tartozik. A felejtés nem utólag, az emberi feledékenyég következtében történik a differenciával". ${ }^{359}$ Vagyis, mivel csak a tradíció nyelvét beszéljük, elkerülhetetlenül azon kell beszélnünk magáról a tradícióról is, de ugyanezen okból kifolyólag csakiskísérleti jelleggel tehetjük ezt. Valami elfeledettről beszélünk, ami lényegénél fogva elfeledett, mert csak ebben a felejtésben van. A nyelv, amiből nem tudunk kilépni, azon tradíció nyelve, melyben gondolkodásunk a kezdetektől mozog, mely előbb ontológiai, majd a kereszténység megjelenésétől kezdve onto-teológiai jellegü. Utóbbi alatt azt az előfeltételezést értjük, hogy a minden létezés kezdeténél és végénél álló azonosság, amely gondolkodásnak és létezésnek egyaránt előfeltétele, maga Isten; Heidegger épp ezért pontosít: a metafizikus alaptendencia az „onto-teo-lógia”, melyben az „onto-lógia” és a „teo-lógia” egymást feltételezik. Ebben a tradícióban a Létet létezőként, a létezőt pedig a Létben gondoljuk el, azaz egymással mindig szubjektum-objektum viszonyban levőként. Ha azonban ezt tesszük, már mindig is a kettő különbségét vesszük alapul. De hogyan gondoljuk el ezt a differenciát? Megkülönböztetésként, mely az azonosból különbözőt csinál. De miért van ez? - teszi fel a kérdést Heidegger. A válasz nyilvánvaló: gondolkodásunk alapvetően reprezentacionalista természetéből kifolyólag, melyből az az előfeltevés ered, hogy ami látszik, az van is - hogy a létező és a Lét egybeesik. Azonban, ha eltekintünk ettől a prekoncepciótól, és a Létet éppen ellenkezőleg, az azonosság helyett a különbség terminusaiban gondoljuk el, olyanként, ami éppen a differencia által van, akkor olyan elrejtett-elfeledettként kell elgondolnunk, ami tehát nincs, és amely ilyenként egyszerre „megérkezés” [Ankunft] és „túláradás” [Überkommnis]. Így az ontológiai differencia, mint a Lét és a létező, a „megérkezés” és „túláradás” megkülönböztetése: „kihordás” [Austrag], elrejtetlen elrejtettségben-tartás. Heidegger tehát azt állítja: ez az ontológiai differenciát „kihordó” „elrejtetlen elrejtettségben-tartás” a

\footnotetext{
${ }^{358}$ Heidegger (1978) s. 24.

${ }^{359}$ Heidegger (1978) s. 25.
} 
metafizika alapjelensége, mely a kezdetektől, korszakokon átívelően már mindig is meghatározta gondolkodásunkat, és amely mindezidáig épp elrejtettsége révén menekült meg a kérdésessé-tételtől. De hogyan függ össze a metafizika onto-teo-logikus jellege, és az ontológiai differencia elfelejtése? Az ,isteni” révén, mondja Heidegger, mely magában a „lényeg” fogalmában (ti. acausa sui tételezésével) tör be a metafizikába, és amely természeténél fogva az elrejtettségben van. Ebben az értelemben állítja tehát, hogy az „Istentelen” gondolkodás, amilyen Nietzschéé is, lényegét tekintve egybeesik a metafizikával. Kétséges azonban, hogy a „visszalépés”, melyet az ontológiai differencia kimondásával tettünk, valaha is ösvénnyé, úttá szélesedhet-e. Hiszen, mint láttuk, nyugati gondolkodásunk a metafizika nyelvét beszéli, melynek alapszava a „,van”, amellyel paradox módon valami olyat próbálunk kifejezni, ami még csak nincs is jelen [nicht eigens hervortritt]. ${ }^{360}$

Az, ami tehát nincs, a Semmi, a létezőnek a maga egészében való tagadása, mely létező létezését így a Semmi tételezése nem tagadja, hanem épp ellenkezőleg, előfeltételezi. „A Semmi a teljes különbségnélküliség”, ${ }^{361}$ hiszen amennyiben a létezőt mint olyat a maga egészében tagadjuk, a sokféleség lehetőségét is kizárjuk, hiszen a Semmiben csak a Semmi „van”, de az is az abszolút nemlét módján, mely azonban oszthatatlan. Az ember jelenvalólétéhez való viszonya, „hangoltsága” a Semmi tekintetében a szorongás; a meghatározatlan meghatározhatatlanságától való szorongás. Minden szorongásban a Semmitől szorongunk, mondja Heidegger, melyben szabadon lebegünk, rögzítetlenül, melyben „otthontalanok" vagyunk, melyben semmi sincs sehogy, melyben a dolgok „elmozdulásukban mint olyanban felénk fordulnak”. 362 A Semmi tehát lényege szerint nincs sehol és sehogyan, a sehol- és sehogyan-nem-lét, a semmi maga az elmozdulás; de nem mint esemény és nem mint tagadás, hanem éppen, mint a Semmi létezése: mint „semmítés” - így érti Heidegger, hogy „a Semmi semmít”. ${ }^{363}$ Csak azáltal van a létező, hogy a Semmiben és ahhoz képest, annak felszínén van. A jelenvalólétnek ez a már mindig is a Semmihez viszonyuló, tehát a létező egészén való „túlhaladása” a transzcendencia; az emberi létezés az alapjellege, melynek felfedése a lét értelmére irányuló kérdés előfeltétele. A transzcendencia az elfeledett ontológiai differencia, a megtagadott Semmi. „Olyannyira végesek vagyunk, hogy eredendően nem vagyunk képesek saját elhatározásunk és akaratunksegítségével a

\footnotetext{
${ }^{360}$ Vö. Heidegger (1978) s. 19-42.

361 Martin Heidegger: „Mi a metafizika?” Ford. Vajda Mihály. In: Uő: „... költőien lakozik az ember ...”Válogatott írások. Szerk. Pongrácz Tibor, Ford. Bacsó Béla et al. T-Twins - Pompeji, Budapest - Szeged, 1994b, 19. o.

${ }^{362}$ Heidegger (1994b) 22. o.

${ }^{363}$ U. ott 24. o.
} 
Semmivel szembesíteni magunkat. A jelenvalólétben oly mélyre ás le a mulandóság [Verendlichung], hogy a legsajátabb és legmélyebb végesség megtagadtatik szabadságunktól." 364 Ugyanakkor, mondja Heidegger, minden megismerés alapfeltétele az a csodálkozás a létező létezése felett, melyet csak a Semmi létezése tesz lehetségessé. A létezőn való túllépésben, a meta-fizikában tehát az emberi létezés legsajátabb természete nyilvánul meg. 365

\section{1. b. Nietzsche ,metafizikája”}

„Metafizikán a létezőnek mint olyannak az egészében vett igazságát értjük”366 _ fogalmaz Heidegger több helyütt. A Nietzsche nihilizmus-felfogásáról 1943-ban, szűk körben tartott előadásában, mely voltaképpen az 1936 és 1940 között elhangzott freiburgi egyetemi lekcióknak, illetve a Nietzsche-monográfia második kötetének a summázata volt, annak hangsúlyozására törekszik, hogy Nietzsche filozófiája „elvakult kísérlet”, mely „lényeglehetőségeitől” fosztotta meg a metafizikát, miközben „puszta értelemadással igyekszik kivonni magát az értelmetlenség alól”. ${ }^{367}$ Heidegger úgy véli: a nyugati metafizika ugyan elgondolja a létezőt mint létezőt, de annak igazságát, tudniillik a létező és a Lét ontológiai differenciáját, illetve a Lét ontológiai kitüntetettségét elfedi, elfelejti. Nietzsche gondolkodásának, tehát „metafizikájának” tárgya a nihilizmus, mely a nyugati civilizáció történetének alapmozgása. ${ }^{368} \mathrm{Az}$ „Isten halott” kimondásával Nietzsche „esztelen embere”369 a metafizikát legfelsőbb hatalmától, hatóerejétől fosztja meg; Heidegger szerint azonban ezzel nem tesz mást, mint szembefordul a metafizikával, de még annak keretein belül marad. Ha pedig ezt teszi, mondja Heidegger, valójában nem megszünteti vagy meghaladja, hanem pusztán saját leglényegibb lehetőségétől, tudniillik a létező igazságának elgondolásának lehetőségétől fosztja meg a metafizikát - és így nyilván saját gondolkodását is. Heidegger úgy értelmezi a nietzschei metafizika-kritikát, hogy annak Nemje abból a sokkal eredendőbb Igenből származik, melyet Nietzsche a régieket szükségszerűen felváltó új értékekre mond. A nihilizmus tehát mindaddig csak részleges, amíg beéri a fennálló értékek tagadásával (ez a

\footnotetext{
${ }^{364}$ U. ott 28-29. o. (kiemelés tőlem, L. E.)

${ }^{365}$ Vö. u. ott 13-34. o.

${ }^{366}$ Ld. többek között Martin Heidegger: „Nietzsche mondása: »Isten halott«.” Ford. Czeglédi András. In: U. ő: Rejtekutak. Osiris, Bp., 2006, 183. o.; illetve NI II:205.

${ }^{367}$ Heidegger (2006) 183. o.

${ }^{368}$ Vö. NI II:90-109. ; 336-400.

${ }^{369}$ Ld. VT 125 . §
} 
pesszimizmus); csak akkor teljesedhet ki, ha a felszámolt régi értékrend helyére újat állít - és Nietzsche pontosan ezt teszi. Az új értékek tételezésének új alapelve a hatalom akarása, melyben az embert felülmúló ember saját magát akarja, a létező léte így ebben az akarásban tételezve, ennek alárendelve van. ${ }^{370}$ A létező „,szubjektitása”, mely Heidegger szerint a hatalom akarása, mint az új értéktételezés alapelve áll fenn, ennélfogva azt jelenti, hogy a létező mint olyan tárggyá vált önmaga számára, ${ }^{371}$ így maga a lét a hatalom akarásának feltételévé degradálódik. „Az »akarat«, ha a létező létezőségének alapvonásaként fogjuk fel, nem más, mint a létezőnek a valóságossal való azonosítása oly módon, hogy a valóságos valóságossága felhatalmazást nyer arra, hogy feltétel nélkül lehetősége nyíljon a folyamatos eltárgyiasításra." ${ }^{372}$ Azzal, hogy megöltük Istent, megszüntettük a Létet mint önmagában létezőt, így a „létezőnek mint olyannak az egészében vett igazságát” tételeztük és birtokunkba vettük - a nihilizmus tehát metafizika, a „metafizika” kifejezés pedig a lét történetének egy szakaszát jelöli. ${ }^{373}$

A lét történelmi sorsából kiindulva a nihilizmus nihilje azt jelenti, hogy a léttel semmi sincs. A lét nem jut saját tulajdon lényegének napvilágára. A létező mint olyan megjelenésében kimarad a lét maga. A létező igazsága elesik. Elfelejtődik. [...] A nihilizmus azt jelenti: mindennel minden szempontból semmi sincs. A minden az egészében vett létezőt jelöli. A létező azonban minden saját szempontjából úgy van, amiként létező módjára tapasztaljuk. A nihilizmus ekkor azt jelenti, hogy a létezővel mint olyannal a maga egészében semmi sincs. Ám a létező, amiként és ahogyan az, a létből van. Feltéve, hogy a léten múlik minden »van«, a nihilizmus lényegi létezése abban áll, hogy magával a léttel semmi sincs. ${ }^{374}$

Heidegger úgy véli, a hatalom akarása Nietzsche filozófiájának központi momentuma, mely nem előkészíti, hanem betetőzi az örök visszatérés gondolatát. A hatalom akarása Nietzsche gondolkodásán és életművén belül is kitüntetett: egyrészt a tervezett, de soha be nem fejezett főmü címeként; másrészt, mint az emberi létezés alapkaraktere - a hatalom akarása a „végső tény, amivé válunk". ${ }^{375}$ A hatalom akarása mint tervezett mủ és mint gondolatmenet

\footnotetext{
${ }^{370}$ Vö. NI II:127-136.

${ }^{371}$ Vö. NI II:451-455.

${ }^{372}$ Martin Heidegger: „Utószó a »Mi a metafiziká?«-hoz.” Ford. Vajda Mihály. In: Uő: „,... költőien lakozik az ember ...”Válogatott írások. Szerk. Pongrácz Tibor, Ford. Bacsó Béla et al. T-Twins - Pompeji, Budapest Szeged, 1994c, 105. o.

${ }^{373}$ Vö. Heidegger (2006) 183-233. o., illetve NI II:199-240.

${ }^{374}$ Heidegger (2006) 229-230. o.

${ }^{375}$ KSA 11.661 „Zum Plan. Unser Intellekt, unser Wille, ebenso unsere Empfindungen sind äbhängig von unseren Werthschätzungen: diese entsprechen unseren Trieben und deren Existenzbedingungen. Unsere Triebe
} 
Heidegger szerint három fázison ment keresztül: az első 1882-83 közé tehető, a Zarathustra által fémjelzett időszakra; a második 1885-től 1887-ig, a morálkritikák megszületése idejére; a harmadik pedig az összeomlás előtti utolsó „tiszta” periódusra, mely nagyjából 1887-től 1888 végéig tartott. Az első szakaszban minden érték átértékelésének kísérletét Nietzsche még az örök visszatérés gondolatának égisze alatt tervezi; ${ }^{376}$ Heidegger szerint azonban a „hatalom” Nietzsche számára minden kontextusban ugyanazt jelenti: a hatalom akarását. A második fázisban már ténylegesen a hatalom akarása lesz a minden érték átértékelésére irányuló kísérlet alapelve, a tervezett főmű ekkortól „A hatalom akarása” címen szerepel a jegyzetekben; a harmadik fázisban pedig az alcím: „minden érték átértékelésének kísérlete” a föcím és a koncepció konstitutív elemévé válik. A tervezett főmü három alapfogalma tehát az „örök visszatérés”, a „hatalom akarása” és „minden érték átértékelése”; a különböző variációk Heidegger meglátása szerint pusztán szerkezetük tekintetében különböznek. Az örök visszatérés és a hatalom akarása legbelsőbb koherenciáját az átértékelés „igazságossága” biztosítja, ami pedig a nyugati metafizika történetének lényegi tényezője. Nietzsche kritikája valójában nem a metafizikai hagyomány meghaladását, hanem annak betetőzését jelenti, hiszen Nietzsche maga sem akart mást, mint „minden érték átértékelésén” keresztül egy új „alapgondolattal” helyettesíteni a régit. Ennek szellemében Heidegger elsőként az „alapelv” kérdését kezdi tárgyalni, amely, mint mondja, az új rendszer számára nélkülözhetetlen. $A$ hatalom akarása harmadik könyvének címét: „Egy új értéktételezés elve”, a következőképp kell érteni: , ,az új alap, amelyből a jövőben az értékelés új módja és típusa sarjad, és amelyen nyugszik majd". ${ }^{377}$ Mivel pedig a tervezett fömü a hatalom akarásával foglalkozik, és a harmadik könyv az alapelvet keresi, úgy ez az alapelv nem lehet más, mint maga a „hatalom akarása”. Ha pedig meg akarjuk alapozni azt, aminek lennie kellene (most és a jövőben), az csak úgy lehetséges, mondja Heidegger, ha az igazság már eleve jellemzi azt, ami van, bármi legyen is az - hiszen „,hogyan máshogy határozhatnánk meg, hogy mi legyen?”378

Heidegger interpretációjában Nietzsche „metafizikájának” öt „alapszava” [Grundwort]: a „nihilizmus”, az ,igazságosság”, a „hatalom akarása”, „,ugyanannak az örök visszatérése” és az „emberfeletti ember”. ${ }^{379}$ Ezen belül a „hatalom akarása” a létező mint

sind reduzirbar auf den Willen zur Macht. Der Wille zur Macht ist das letzte Factum, zu dem wir hinunterkommen." (kiemelés tölem, L. E.)

${ }^{376}$ U. ott

${ }^{377}$ NI I:41. „Der neue Grund, aus dem die Weise und Art der Wertsetzens künftig entspringt, auf dem sie ruht.”

${ }^{378} \mathrm{U}$. ott „Wie soll anders sonst bestimmt werden können, was sein soll?”

${ }^{379}$ A fejezet magyar fordítója (Ld. Martin Heidegger: „Nietzsche metafizikája.” Ford. Sarankó Márta. In: EX Symposion. 1994d. Nietzsche-különszám. 42-54. o.) a „hatalom akarása” helyett a „hatalomra irányuló akarat”, az ,igazságosság” helyett pedig a „jogosultság” kifejezést használja. Mi ettől szándékosan térünk el. Az első 
olyan létét, a lét alapjellegét jelenti; ezért az „akarás” nem a biologisztikus-naturalisztikus értelemben vett „törekvés”, hanem parancs, melyet az akarat saját magára ró ki, hogy abban saját végrehajtását parancsolja meg önmaga számára. Heidegger rámutat: Nietzsche nem azért használ két különböző kifejezést, hogy a kettőt ténylegesen a hatalomakarás két aspektusaként különböztesse meg, hanem épp ellenkezőleg: a hatalom és az akarás lényegi összetartozását fejezi ki általa. A „hatalom akarása” a hatalom önmaga felett gyakorolt hatalma, így tehát a keletkezés a hatalom folyamatos, fázisok sokaságán áthaladó növekedését jelenti. Ahhoz, hogy helyesen értsük a „hatalom akarása” nietzschei koncepcióját, erre az eredeti egységre kell koncentrálnunk, melyben az, amit fölülmúlnak és ami fölülmúl, egy és ugyanaz a fölülmúlásban. Az „értékek” a hatalomakarás alakzatai, melyek az „uralom képződményeiben” manifesztálódnak (ld. megismerés, morál, vallás); a perspektivizmus pedig a „hatalom akarásának” az értéktételezés elveként való felfogását és alkalmazását jelenti. $^{380}$

Mivel Nietzschénél minden metafizika az értékbecslés adott rendszere, vagyis alapjaiban morális, a modernizmust, melyben az eddig elfogadott értékek elértéktelenedtek, a semmi akarása, a „nihilizmus” korának tekinti; egészen pontosan a ,nihilizmus” mint az egész nyugati történelem alaptendenciája betetőzésének. A „nihilizmus” azonban eredendően pozitív a totális átértékelés értelmében, melynek során minden létező mássá válik, mint ami volt, és amelynek feladata a létező eredeti egységének visszaállítása. Az a „nihilizmus” tehát, amely beéri a fennálló tagadásával, de helyére semmi újat nem állít, „részleges” nihilizmus; a teljes vagy „extrém” nihilizmus attól kezdve áll fenn, mikor felismerjük, hogy magánvaló igazság mint olyan nem létezik. Amennyiben beérjük ennyivel, még midig csak „passzív” nihilizmusról beszélhetünk; az „aktív” nihilizmus ugyanis a vég akarása, a megsemmisülés akarása, mely „eksztatikus” formájában totális tagadássá válik, majd pedig, ezen is túlhaladva, „klasszikus” nihilizmusként egy új értékmeghatározás elvévé. Nietzsche filozófiáját ez utóbbi értelemben, a dionüszoszi teremtve-megsemmisítés filozófiájaként értékeli. ${ }^{381}$

Mikor tehát Nietzsche a folyamatos keletkezés tételezésével az összes fennálló értéket tagadja, a „klasszikus” nihilizmus pozíciójába helyezkedik, ami nem megsemmisítést, hanem magát a módot jelenti, ahogyan a lét egésze a jelenlétbe jön; ezt a folyamatot pedig, mondja

esetben nem tartjuk szükségesnek ezt a fajta „korrekciót”, a második esetben pedig úgy véljük, a Heidegger által használt „Gerechtigkeit” terminust helyesebb az „igazságosság” az „igazságnak” igazságot szolgáltató, azt jogaiba helyezö értelmében olvasni.

${ }^{380}$ Vö. NI II:257-272.

${ }^{381}$ Vö. NI II:272-282. 
Heidegger, a metafizika nyelvén „ugyanannak az örök visszatérése” jelöli. A ,hatalom akarása" annak kimondása, hogy mi a létező mint olyan összetétele tekintetében, az „,ugyanannak az örök visszatérése” pedig annak, hogy hogyanvan a létező egészként ebben az összetettségben. Az örök visszatérésben a létező egészként van,mely utóbbi a Lét alapvető karaktere, és amely a hatalom akarás révén lép az örök visszatérésbe, mely nélküle a folyamtos keletkezés ördögi körét futná. „Ugyanannak az örök visszatérése” mint folyamatos keletkezés [Werden] tehát a „hatalom akarása” révén tér vissza mindig ugyanakként, ti. Létként [Sein]. Heidegger konklúziója: „ugyanannak az örök visszatérése” teszi, hogy és ahogyan ez a világ, mely sokaság és értelemnélküliség, mégis a létező egységeként - van. Mivel az igazság csak az ember számára bír értékkel, mondja Heidegger, a metafizika, amely „a létező igazsága az egészben”, csak az ember által és az emberben teljesülhet be; ez a beteljesülés maga az „emberfeletti ember”. Mint beteljesülés, az „emberfeletti ember” lényegét tekintve az eddigi ember lényegének tagadása kell, hogy legyen, tehát az észnek mint olyannak, ezzel pedig magának a metafizikai gondolkodásnak a tagadása. Az észnek már csak Öntudatként, azaz az önmagamról való tudásként van létjogosultsága; így az ész nem más, mint a „hatalom akarásának” egyik, sőt kitüntetett alakzata. ${ }^{382} \mathrm{Az}$ „emberfeletti emberre” azért van szükség, mert a metafizikai hagyományban az ember mint a „beteljesedés” felé haladó szubjektivitás van tételezve, amely tehát „beteljesedése” pillanatában a „hatalom akarása" útjában áll, és mint ilyent, meg kell haladni. Az önmagát a beteljesülésben meghaladó ember tehát maga is része a létező örökké ugyanakként visszatérő egységének. ${ }^{383}$

A folyamat, melynek során az ,igazság” egyre inkább szubjektivizálódott, Heidegger szerint nem más, mint a metafizika története. A „hatalom akarása” mint a „létező igazságát az egészben" kimondó gondolat lényege tehát, hogy látszani-engedi a létező egészét, és ő maga is csak ebben a látszani-engedésben teljesedhet ki. A látszani-engedés, a láttatás pedig a metafizikai tradícióban az ,igazság” legsajátabb tulajdonsága, amely, mint olyan, a „megnyilvánulásban” van. „... annak a feltárása, ami elrejtőzik: elrejtetlenség. Ily módon »igazságosság«, mert ez a hatalom akarásának legmagasabb foka, ez az igazság lényegének voltaképpeni meghatározása.”384 Ahogyan Nietzsche írja 1884-ben: „,az igazságosság teremtő, kizárólagos, megsemmisítő gondolkodásmód, mely az értékbecslésekből ered: magának az

\footnotetext{
${ }^{382}$ Vö. NI II:300-303. Emlékezzünk rá, hogy test alatt Nietzsche többé már nem a lélek ellentéteként azonosított fizikai testet [Körper] érti, hanem a testet mint organizmust. Ahogyan Zarathustra mondta: a lélek [Seele] már mindig is test [Leib]. (Vö. Z I:705-764 „A test becsmérlöiröl.”)

${ }^{383}$ A ,hatalom akarásának” önmagára-irányultsága Heideggernél a „szubjektivitás” mint olyan jellemzője.

${ }^{384} \mathrm{NI}$ II:325. „... das Erscheinenlassen als Entbergen des Verborgenen: die Unverborgenheit. Also is die »Gerechtigkeit«, weil die höchste Weise des Willens zur Macht, der eigentliche Bestimmungsgrund des Wesens der Wahrheit."
} 
életnek a legmagasabb reprezentációja.”385 Az „,igazságosság” „teremtő, kizárólagos és megsemmisítő gondolkodásmódként"pedig nem más, mint a fennálló értékek átértékelése. A hatalom akarása abszolút és tökéletes szubjektivitásának metafizikájában az igazság szükségszerüen mint »igazságosság « nyilvánul meg., ${ }^{386}$ Egyedül az igazolódik tehát, mondja Heidegger, ami kielégíti az „,igazság” kritériumát, mely lényege szerint a „hatalom akarásának legmagasabb reprezentációja”. Azáltal ugyanis, hogy a létező maga is a hatalom akarásának egy alakzata, a hatalomnak az önmaga felett gyakorolt hatalom gyakorlására való joga igazolódik. Csak így lehet a létezőről mint igazságról és mint egészről beszélnünk. A „hatalom akarása” tehát mint ,igazság” és mint „,igazságosság” - reprezentáció. ${ }^{387}$ „Az önmagát-tudás teljességgel szubjektummá válik. Az önmagát-tudásban gyülik össze minden tudás és ennek tudhatósága." 388

Nietzsche akarat-felfogásának tárgyalásakor, mondja Heidegger, alapvető annak a Schopenhauerétől való különbsége. A schopenhaueri, általában vett akarat ugyanis nem létezik; pusztán maga a törekvés az, ami határozatlan lehet, mind tárgya, mind alanya tekintetében. A valami iránti puszta törekvésben nem vagyunk úgymond magunk elé helyezve, ezért a törekvés nem irányulhat önmagunkon túlra, mondja Heidegger; ellenkezőleg, teljesen elmerülünk benne. Az akarás ezzel szemben, mint határozott önmagunk iránti nyitottság, épp, hogy önmagunkon túlra irányul. Az akarat állandó készenlétben és nyitottságban van önmagán túlra, a hatalmat pedig a fölött gyakoroljuk, ami kinyilvánítja magát az akaratban, tehát éppen az akarás fölött. Heidegger szerint tehát ,az akarat hatalom és a hatalom akarat". ${ }^{389} \mathrm{Az}$ akarat maga ez az állandó készenlét, önmaga iránti nyitottság; heideggeri terminussal „feltárultság” [Erschlossenheit]. Utóbbi kifejezés pedig, mint tudjuk, kulcsfontosságú a jelenvalólét analízisében: „a feltárultság a jelenvalólét lényegbeli létmódja. Igazság csak annyiban és addig »adódik " [gibt es], ameddig van [ist] jelenvalólét."390 Heidegger kimerítően értekezik a nietzschei és a schopenhaueri akarat-fogalmak különbözőségéről, és arról, hogyan értelmezte félre mindkét említett gondolkodó a kanti esztétikát, majd hosszasan tárgyalja a Nietzsche filozófiája és a platonizmus közti párhuzamokat. Mindennek részletes vizsgálata e helyt nem áll módunkban, így a hatalom

\footnotetext{
${ }^{385}$ KSA 11.141 „Gerechtigkeit als bauende ausscheidende vernichtende Denkweise, aus den Werthschätzungen heraus: höchster Repräsentant des Lebens selber."

${ }^{386}$ NI II:325. „In der Metaphysik der unbedingten und vollendeten Subjektivität des Willens zur Macht west die Wahrheit als die »Gerechtigkeit«."

${ }^{387}$ Vö. NI II:328-329.

${ }^{388}$ Heidegger (2006) 212. o.

${ }^{389}$ NI I:52. „Wille ist in sich selbst Macht. Und macht ist da sin-sich-ständige Wollen. Wille ist Macht und Macht ist Wille."

${ }^{390}$ LI 44. c. $\S$
} 
akarását tárgyaló fejezet végére ugrunk, ahol Heidegger a perspektivizmus problémáját tárgyalja. Az említett, kanti és platóni esztétika és ismeretelmélet vonatkozásaira fókuszáló fejezetekben Heidegger a hatalom akarását mint mủvészetet, tehát mint lényegileg metafizikus gondolatot mutatja fel. Konklúziója a következő:

[...] a valóság, a létezés: látszat, a perspektivikus látszani-engedés értelmében. De ennek a realitásnak megfelelően egyidejűleg a perspektívák sokfélesége, illetve a tévedésnek és megszilárdulásának a lehetősége is fennáll, ami a »puszta« látszat értelmében vett igazság lehetőségét jelenti. Ha az igazságot látszatként tekintjük, amely pusztán jelenség és tévedés, annak következménye, hogy az igazság a megszilárdult látszat, mely a perspektivikus látszás szükségszerü velejárója - illúzió. Nietzsche gyakran azonosítja ezt az illúziót »a hazugsággal«. [...] A müvészet mint látszani-akarás a hatalom akarásának legmagasabb alakja. Utóbbi azonban, mint a létező alapvető karaktere, mint a valóság lényege, maga a lét, amely önmagát akarja akkor, amikor keletkezéssé akar válni. Ily módon Nietzsche a hatalom akarásában a Lét és a Keletkezés régi ellentétnek egységét kísérli meg elgondolni. A Lét, mint állandóság, a keletkezés keletkezéssé-lenni engedése. Ezzel feltártuk az »örök visszatérés « gondolatának eredetét. ${ }^{391}$

Heidegger olvasatában az ugyanannak örök visszatéréséről szóló tan helyes értelmezése csak úgy lehetséges, ha azt a platonikus-keresztény hagyomány talajából sarjadóként, azzal való konfrontációként értelmezzük; olyan eszmeként, mely a platonizmus elkorcsosulását kéri számon a modernizmuson. Meg kell azonban vizsgálnunk, vajon Nietzsche metafizikus alapvetése, mely az „utolsó pozíció, melyet a nyugati gondolkodás felvett”, ${ }^{392}$ feltette-e, és ha igen, milyen módon, a filozófia alapkérdéseit; és amennyiben ezt elmulasztotta, rá kell jönnünk, miért.

Az örök visszatérés tehát, a heideggeri olvasatban lényegileg „,ugyanannak az örök visszatérése”, és nem korábban, mint 1881 augusztusában, „6000 lábnyira túl emberen és

\footnotetext{
${ }^{391}$ NI I:248, illetve 251. „Der Realität, das Sein, ist der Schein, im Sinne des perspektivischen Scheinenlassens. Aber zu diesem Realität gehört nun zugleich die Mehrheit von Perspektiven und so die Möglichkeit des Anscheins und dessen Festmachung, d. h. die Wahrheit als eine Art von Schein im Sinne des »bloßen« Scheins. Wird die Wahrheit als Schein genommen, d. h. als bloßer Schein, als Irrtum, dann besagt dieses: Wahrheit ist der zum perspektivischen Scheinen notwendig gehörige, festgemachte Schein, der Anschein. Nietzsche setzt nun oft diesen Anschein gleich mit der Lüge [...] Die Kunst als Wille zum Schein ist der höchste Gestalt des Willens zur Macht. Dieser aber ist als der Grudcharakter des Seienden, als das Wesen der Realität, in sich dasjenige Sein, das sich selbst will, indem es das Werden sein will. So versucht Nietzsche im Willen zur Macht die ursprüngliche Einheit des alten Gegensatzes von Sein und Werden zusammenzudenken. Sein als die Beständigkeit soll das Werden ein Werden sein lassen. Der Ursprung des Gedankens der »ewigen Wiederkehr« ist damit gewiesen.” (kiemelés az eredetiben. L. E.)

${ }^{392}$ NI I:258. „Schließlich muß angesichts dieser metaphysischen Grundstellung Nietzsches als der letzten, die der abendländische Denkenerreicht hat, gefragt weden, ob und wie in ihr die eigentliche Frage der Philosophie gefragt ist oder ob sie ungefragt bleibt, und wenn ja, warum."
} 
időn" ${ }^{393}$ keletkezett. ${ }^{394}$ Mint mondja, igen nagy jelentőséggel bír, hogy maga Nietzsche mely gondolatokat szánta közlésre, és melyek azok, melyek csak a Nachlassból kerültek elö (Heidegger a Großoktavaufgabét használta). Először tehát az előbbieket veszi sorra, kezdve az örök visszatérés tanának konkrét megjelenéseivel; melyek közül az első $A$ vidám tudomány 341-es, „A leghatalmasabb teher” címet viselő aforizmája. Heidegger szerint, amikor Nietzsche azt írja, hogy ugyanannak az örök visszatérését akarva a leghatalmasabb terhet rójuk „cselekvésünkre”, akkor „cselekvés” alatt semmiképp sem gyakorlati tevékenységet vagy etikai értelemben vett cselekedetet ért, hanem az ember önmagához és a létezőhöz való viszonyainak teljességét. „Az örök visszatérés gondolata teher lesz - ami van, az válik meghatározóvá a létező egészén belüli saját bennelétünk számára." ${ }^{395}$ Az ember ezzel a rettentő gondolattal csak „legmagányosabb magányában”396 szembesülhet, mely megelőz minden individuációt, mely korábbi, mint az Én és Te, mint az Én és Mi. Ez az az állapot, melyben a jelenvalólét [Dasein] mint autentikus létezés önmagára találhat. Heidegger hangsúlyozza: Nietzsche maga nem használja a „létező egésze” kifejezést; ezt ő csak a legtágabban értett nem-nemlétező egészének megjelölésére alkalmazza, mely egyszersmind a legproblematikusabb kategória és a legalapvetőbb kérdezés tárgya. ${ }^{397}$

Heidegger tíz pontba szedve összegzi az örök visszatérés gondolatát: 1. a gondolat a világra mint a létező egészére vonatkozik. Fontosnak tartja kiemelni, hogy az örök visszatérésben az elmúlás elsőbbséget élvez az élettel szemben. 2. Az élet általános karaktere az „erö”, amely azonban Heidegger szerint Nietzschénél hangsúlyozottan nem-fizikai terminusokban értendő. Azok, akik Nietzsche filozófiáját görög mintára a „statikussal” szembenálló „dinamikus” gondolkodásmódként interpretálják, mérhetetlen kavarodást okoznak; hiszen az ilyen terminusok pusztán a gondolkodás „fizikai-technikai” területén alkalmazhatók, nem pedig a metafizikában, ahova az „erő” mint a hatalom akarása nietzschei koncepciója tartozik. 3. Az erő korlátolt, hiszen ha végtelenül növekedhetne, idézi Nietzschét, akkor vajon mi táplálná? ${ }^{398}$ Abból, hogy Nietzsche hangsúlyozza: a végtelenség

\footnotetext{
${ }^{393} \mathrm{EH} 91$. o.

${ }^{394}$ Vö. NI I:263.

${ }^{395}$ NI I:273. „Für das Mitteninnenstehen im Seienden im Ganzen soll der ewigen Wiederkunft ein »Schwergewicht«, d. h. bestimmend sein."

${ }^{396}$ VT 341. §

${ }^{397}$ Vö. NI I:277. „Nietzsche spricht nicht vom Seienden im Ganzen. Wir gebrauchen diesen Namen, um zunächst all das zu benennen, was nicht slechthin nichts ist [...] Der Namen »das Seiende im Ganzen« nennt somit das Fragwürdigste und ist daher das fragwüedigste Wort."

${ }^{398}$ Vö. KSA 9.525 „Das unendlich neue Werden ist ein Widerspruch, es würde eine unendlich wachsende Kraft voraussetzen. Aber wovon sollte sie wachsen! Woher sich ernähren, mit Überschuß ernähren! Die Annahme, das All sei ein Organism, widerstreitet dem Wesen des Organischen.”
} 
összeférhetetlen az erő gondolatával, Heidegger szerint egyenesen következik, hogy az erő valami meghatározott, definiált; méghozzá az ,igazság” értelmében. 4. Így tehát a világ, melynek ez a hatalomakarásként értett, véges és meghatározott erő az alapelve, maga is véges és meghatározott. A természete szerint véges és határolt világban pedig a „kozmikus erő” sem nem csökken, sem nem növekszik. 5. Ez azonban nem nyugalmi állapotot, hanem a folyamatos alakulás, vagy még inkább változás értelmében vett állandó keletkezést eredményez. 6. A valóság, mint a létező egésze azonban, a megismerhetőség tekintetében azonban mégis ,végtelen”. Heidegger szerint tehát, bár Nietzsche fizikai értelemben véges világról beszél, ismeretelméleti szempontból éppen a folyamatos keletkezés tételezése eredményez metafizikai értelemben vett „végtelenséget”. 7. A véges erő azonban nem térben képzelendő el, mert a tér, akárcsak az ,anyag” fogalma, szubjektív forma; melyet már eleve az erők és az erők viszonyai alakítanak. A Lét az, ami lényege szerint tartalmazhatja a semmi lehetőségét is, de maga az abszolút Semmi nem létezik, hiszen minden erő. 8. A tér látszatkarakterével szemben az idő aktuális, határtalan és végtelen; ez a nietzschei Öröklét. ${ }^{399} 9$. Annak, hogy Nietzsche számára a „világ összkaraktere [...] öröktől fogva a káosz”, 400 Heidegger szerint kettős jelentősége van. Egyrészt az örökös keletkezést a panta rhei, a „minden folyik” értelmében jelenti ki; másrészt pedig felveszi a „dolgokat” a folyamatos keletkezés rendjébe anélkül, hogy szükségessé tenné az egység és sokaság ellentétének bevezetését. „A káosz eszerint a lét mint egész azon képzetének a neve, amelynek révén sokféleség keletkezése szükségszerü, mégpedig úgy, hogy az »egység« és a »forma« eredendően lehetetlen”401 Nietzsche tehát a világ totalitásának „káoszként” való reprezentációjával készíti elő a lét mint egész „humanizációja” elleni támadást. Csak így (ti. az örök visszatérés gondolata révén) válik lehetségessé számára, hogy ezen törekvésétől közvetlenül eljuthasson a látszólag ellentéteshez, mikor a hatalom akarásának gondolatával a létező legmagasabb szintű humanizálását követeli. Nietzsche, mondja Heidegger, óva int a

\footnotetext{
${ }^{399}$ Vö. KSA 10.9. sk. „Grundsätze. Der letzte physikalische Zustand der Kraft, den wir erschließen, muß auch nothwendig der erste sein. Die Auflösung der Kraft in latente Kraft muß die Ursache der Entstehung der lebendigsten Kraft sein. Dem einen Zustand der Negation muß der Zustand der höchsten Position folgen. Raum ist wie Materie eine subjektive Form. Zeit nicht. Raum ist erst durch die Annahme leeren Raumes entstanden. Den giebt es nicht. Alles ist Kraft. Bewegtes und Bewegendes können wir nicht zusammen denken, aber das macht Materie und Raum. Wir isoliren. Die Entwicklung eines Dinges erlaubt Rückschlüsse auf die Entstehung des Dings. Alle Entwicklung ist eine Entstehung. Materie, Stoff ist eine subjektive Form. Wir können uns Nichts anders als stofflich denken. Auch Gedanken und Abstrakta bekommen von uns eine sehr verfeinerte Stofflichkeit, die wir vielleicht ableugnen: nichts destoweniger haben sie eine solche. Wir haben uns daran gewöhnt, diese feine Stofflichkeit zu übersehn und vom „Immateriellen“ zu reden. Ganz wie wir todt und lebendig, logisch und unlogisch usw. getrennt haben. Unsere Gegensätze verlernen — ist die Aufgabe.

${ }^{400}$ VT 109. \&

${ }^{401}$ NI I:349. , „)Chaos « ist darnach die name für diejenige Vorstellung vom Seienden im Ganzen, dergemäß dieses als notwendiges Werden mit einen Mannigfaltigkeit, so zwar, daß »Einheit« und »Form« ursprünglich ausgeschlossen bleiben.”
} 
világ organizmusként való értelmezésétől, hiszen az organikus szervezet mindig igényel valami rajta kívül állót, hogy abból táplálkozzék, hogy általa maradjon fenn létében. ${ }^{402}$ Heidegger szerint a létező egészének eredendő káoszként való értelmezése a szükségszerűség tételezését implikálja, amely pedig „Moira, fatum, végzet, predesztináció, dialektikus folyamat” ${ }^{\star 03}$ néven már jól ismert a nyugati műveltség történetében. Nietzsche gondolkodását ezért könnyelműség lenne „naturalimusnak” vagy „materializmusnak” bélyegezni, ellenkezőleg: épp a világ összkarakterének káoszként való felmutatása jelzi annak radikálisan metafizikus jellegét. Mint ilyen, nélkülözvén minden misztifikáló csalást vagy szemfényvesztést, felfedi az egyedüli utat, melyen keresztül eljuthatunk az isten(ek)hez - ha ez egyáltalán lehetséges még egyszer az emberiség számára. 10. Összefoglalva: az örök visszatérés gondolata az egészként, mint az élő és élettelen létező egységeként értett lét tekintetében értendő. Ez az egység azonban alapvetően tagolt és strukturált, méghozzá az erő természetéből, és az egészként értett létnek az erő természetéből következő véges voltából adódóan, mely utóbbi úgymond a „fenomenális hatások” mérhetetlensége. ${ }^{404}$

Heidegger kíméletlen Nietzschével: azt állítja, az örök visszatérés gondolata minden tudományos alapot nélkülöz, ami nem is csoda, hiszen a szerző azzal, hogy a fizika területén kereste a bizonyítékokat, olyan mellékvágányra futott, amin nem mozgott elég otthonosan, és aminek amúgy sincs semmi köze a filozófiához. Úgy véli azonban, mindez bocsánatos bűnnek, a „világnézet” felmutatását követelő korszellemnek tudható be. Álláspontja szerint Nietzsche „bizonyítékai” nem állnak meg a lábukon, ám kétségtelenül sok hasonlóságot mutatnak a kortárs fizika álláspontjával: minden éppoly kétséges, mint az ellentéte; minden dolog legalább annyira anyagi, mint amennyire nem. Ez az eredeti tévedés prekoncepciója, mely minden releváns kérdezést már eleve lehetetlenné tesz. Heidegger a következő problémákat veti fel: amennyiben ugyannak örök visszatérése a lét mint egész alapvető meghatározása, akkor ennek arról kell mondania valamit, hogy milyen módon is van a lét egésze; ami pedig csak akkor lehetséges, ha az egészet mint a világ totalitásának konstitúcióját tekintjük. Az erő alapvető karaktere eredményezi a végességet mint a folyamatos keletkezés önmagába történő visszazáródását, ekként a folyamat végtelenbe tartása lehetetlen. A folyamatosan keletkező világ tehát az idő végtelenjében fut oda-vissza anélkül, hogy nyugvópontra jutna - vagy akarna jutni. Mivel pedig a rendszernek nem célja a

\footnotetext{
${ }^{402}$ Vö. NI I:349-353.

${ }^{403}$ NI II:354. „Wir wissen, daß dieser Name von altersher im abendländischen Denken einen Charakter des Seienden nennt, und daß die Notwendigkeit als Grundcharakter des Seienden die verschiedensten Auslegungen erfahren hat: $\mu$ oi $\rho \alpha$, fatum, Schicksal, Prädestination, dialektischer Prozeß.”

${ }^{404}$ Vö. NI II:340-356.
} 
homeosztázis, feltételeznünk kell, hogy a statikus állapot soha nem is létezett, tehát az örökös keletkezés már mindig is fennállt, és a jövőben is folytatódni fog, vég nélkül. A végességbe való visszafordulás azonban azt eredményezi, hogy minden folyamat önmagát ismétli, az örök visszatérésben minden ugyanakként tér vissza: az örök visszatérés tehát ugyanannak az örök visszatérése - circulus vitiosus. Mint ilyen, csak szükségszerüként tételezhető, a világ összkaraktere mint folyamatos keletkezés [Werden] tehát egyszersmind a Lét [Sein] karakterét is felveszi, mint a szükségszerüség káoszának örökké ugyanakként történő visszatérése. $^{405}$

Nietzsche alapvetően ott hibázik, mondja Heidegger, hogy az olyan fogalmakat, mint tér, idő, erő, végesség, káosz, keletkezés vagy visszatérés, megkísérli természettudományos módszerekkel magyarázni; holott az utóbbiak, bár használják az említett fogalmakat, de axiomatikusan, nem pedig önmagukban is problematikusként. Azonban amint az alapfogalmak jelentése után tudakozódva feltesszük a kérdést: $m i$ is az adott dolog lényege szerint, magunk mögött hagyjuk a tudományt, és a filozófia területére lépünk. Nietzsche elmélete tehát valójában nem természettudományos; ez már csak abból is nyilvánvaló, hogy eszébe sem jut észrevételeinek érvényességét a fizika, vagy egyéb tudományok hatókörére korlátozni. Sőt, hangsúlyozza Heidegger, épp az ellenkezőjét teszi: a létező totalitásáról beszél, mely a Lét ugyanakként való örök visszatérésében tárul fel; mindezt bármilyen megalapozás vagy kalkuláció hiányában - tehát metafizikusan. Nietzsche nem pusztán az emberi tapasztalat kategóriáit alkalmazza a létező egészére, hanem mindezt önkényesen teszi és éppen ezáltal, önmagának is ellentmondva, „humanizálja” azokat: Nietzsche párhuzamosan humanizálja a létezőt és dehumanizálja az embert. Hogy a világ összkaraktere a káosz, az az interpretáció teljes szabadságát feltételezi, ami azonban Heidegger szerint nem jelenti a korábbi nézőpontok meghaladását, pusztán egy újfajta egyoldalúságot. Heidegger szerint Nietzsche koncepciója a létező egészéről saját, emberi pozíciójából ered, úgymond önnön emberlétének problematizálásaként értendő. Az emberi létező léte a jelenvalólét, az „itt” pedig létének egyetlen lehetséges és mindenkor szükségszerü helye. Azáltal, hogy létüket jelenvalólétként ismerik fel és alapozzák meg, az emberi lények csökkentik a kárt, melyet a humanizáció okoz az igazság számára. A legnehezebb gondolatot tehát elgondolásának hogyanja határozza meg, vagyis az örök visszatérés-gondolat „elméleti” és „gyakorlati” aspektusainak szétválasztása már eleve nem lehetséges - ez a gondolat ugyanis sem elméletileg, sem gyakorlatilag nem alkalmazható. Nem gondolható el, mert a gondolat

\footnotetext{
${ }^{405}$ Vö. NI I:366-371.
} 
gondolása megkövetelné, hogy aki elgondolja, maga is feloldódjon a gondolatban, gyakorlati szempontból pedig a gondolat elgondolása pillanatában máris túlhaladottá válik. ${ }^{406}$

Heidegger az esszencialista gondolkodók közé sorolja Nietzschét, olyasvalakiként, akit egyetlen „nagy” gondolat elgondolása jellemez, mely a mindenség hogyan- és mibenlétére kíván magyarázatot adni. Nietzsche nem pusztán próféta, hiszen bizonyos értelemben maga is előkészíti a gondolat „érkezését”; azonban nem méri fel és nem tudatosítja annak voltaképpeni nagyságát, a követelményeket és következményeket, melyekkel az jár. A ,gondolkodót”, mondja Heidegger, épp az különbözteti meg a „,tudományos kutatótól”, hogy tisztában van önnön nemtudásával, mely azonban nem egyenlő az egyáltalában lehetséges ismeretek körének meghatározásával; a gondolkodónak azt kell eldöntenie, $m i$ az, ami van, hogy mik a dolgok valójában. Elödeihez hasonlóan Nietzsche is előfeltételezi a létezőnek a Léttel szembeni dominanciáját anélkül, hogy fel tudná mérni egy ilyen döntés következményeit. A hatalom akarásának koncepciója, mint a létező és a Lét közvetlenségét megteremtő gondolat, a metafizikus gondolkodás betetőzésének tekinthető. ${ }^{407}$

\section{2. Érvek és ellenérvek}

Nietzsche filozófiáját, melyet az első részben az ,aktív differencia” általunk bevezetett fogalma segítségével a par excellence differencia-filozófiaként igyekeztünk rekonstruálni, a továbbiakban reprezentáció-kritikára épülő radikális metafizika-kritikaként, végső soron pedig par excellence kritikaként kíséreljük meg felmutatni. Azt állítjuk tehát, hogy az általában vett kritika már mindig is metafizika-kritika, amely csak reprezentáció-kritikaként lehet megalapozott; mely azonban csak differencia-filozófiaként képzelhető el. Egy így értett kritika kritériumait leginkább olyan módszerekkel véljük körvonalazhatónak, amelyeket a falszifikacionizmus tudományelméleti koncepciója vázol fel - tehát hangsúlyozottan nem verifikacionalista módon. Ugyanakkor úgy véljük, a nietzschei kritika radikalizmusa jócskán túlmutat a klasszikus, popperi falszifikacionizmusén, amennyiben magának az általában vett igazolhatóságnak az értékét és lehetőségét vonja kétségbe, és éppen ezért elsősorban a metafizika területén tart számot érvényességre. Amint azt a vizsgálódás kezdetekor

\footnotetext{
${ }^{406}$ Vö. NI I:372-382.

${ }^{407}$ Vö. NI I:473-481.
} 
leszögeztük, Nietzsche gondolkodásának kapcsán a következő három tézist kívánjuk igazolni: 1. Nietzsche metafizika-kritikája, mint amely lényegét tekintve reprezentáció-kritika, a neokantiánus Kant-kritika talaján áll. 2. Az örök visszatérés és a hatalom akarása gondolatában kulmináló metafizika-kritika differencia-filozófiaként van kifejtve. 3. A fenti két állítás távolról sem mond ellent egymásnak, amennyiben a neokantiánus kriticizmus hatása mind egy sajátosan nietzschei falszifikacionizmusban, mind pedig a hatalom akarása révén folyamatos keletkezésben tartott örök visszatérés radikálisan antireprezentacionalista koncepciójában tetten érhető. Az „aktív differencia”, mely jelen, a reprezentáció-kritika gondolata köré felépített Nietzsche-interpretációnk munkafogalma, kifejezetten és bevallottan a posztmodern differencia-gondolkodásra utal és hivatkozik. Úgy véljük, a fenti három tézis igazolása révén tisztábban áll majd előttünk az említett hagyomány két kiemelkedő alakja, Gilles Deleuze és Jacques Derrida Nietzsche-olvasatai közti különbség is, melyet egyik oldalról a differencia abszolút immanens, a másik oldalról pedig annak radikálisan ,elkülönböződő" fogalma határoz meg. Az értekezés első fejezetében a nietzschei filozófia fentiekkel harmonizáló rekonstrukciójára törekedtünk, majd a második rész első fejezetében kommentár nélkül összegeztük Heidegger Nietzsche-kritikájának tartalmát, miközben igyekeztünk azt a heideggeri metafizika-kritika átfogóbb kontextusában tartani. A következőkben tehát oly módon próbáljuk igazolni a fenti téziseket, hogy saját, az első részben felvázolt értelmezésünket az exkurzusokban már jelzett hatástörténeti összefüggések köré összpontosítva, illetve a heideggeri kritikával szembesítve, mintegy „újrapozicionáljuk”. Mielőtt azonban ehhez hozzákezdenénk, sort kell kerítenünk az interpretáció problémájának tárgyalására, melynek jelentősége Nietzsche és Heidegger esetében jóval túlmutat a puszta módszertani kérdéseken.

\section{2. a. Interpretáció és fakticitás}

Minden nyelvteremtő törekvés hátterében a szubjektum-objektum reláció lehető legteljesebb kifejezésének vágya, az embernek a megismerés lehetőségébe vetett metafizikai hitemunkál; minden metanyelv vagy ős-nyelv szó és dolog eredeti egységének visszaállítására törekszik, megpróbál tehát visszatérni valamiféle nyelv elötti tudatba, hogy abban mint eredetben a megértés teljességét fedezhesse fel. Ehhez azonban feltételeznünk kell, hogy 
létezik a világnak és a mi világ-értésünknek ez a világon-túli, transzcendentális értelemben vett eredeti egysége, melyhez csak a megfelelő kódolás, formalizáció szükséges, hogy a characteristica universalis adva legyen. A metafizika-kritika elsődlegesen épp annak a túlvilágnak a létét vonja kétségbe, mely a metafizikai hagyományon belül az „egység” kritériumaként szolgál, valamint ezzel párhuzamosan vitatja a fenti értelemben vett metanyelvek lehetőségét is. Nyilvánvaló, hogy amikor azon kérdés vizsgálatába kezdünk, hogy vajon a nietzschei gondolkodás még metafizika-e, vagy épp ellenkezőleg, Nietzschének sikerült végrehajtania a metafizikus gondolkodás meghaladásáról szóló nagyszabású tervet, akkor a módszertani megfontolások sora végtelenbe fut. Ezt elkerülendő, most, az interpretáció problémájának felmerülésekor nem szándékunk a téma kimerítő tárgyalása, megelégszünk a „fakticitás hermeneutikája” és ,jobban-értés” heideggeri fogalmainak felidézésével, melyek amellett, hogy a Heidegger által alkalmazott interpretációs stratégiával kapcsolatban is igen informatívak, a jelenvalólét „egzisztenciális analitikájának” alapelemei.

A „fakticitás”, a tulajdonképpeniség Heideggernél egyrészt a szubjektivitás határfogalma, másrészt azonban arra is utal, hogy jelenvalólétünk a Létben alapozódik meg, így tehát a „fakticitás hermeneutikája” a jelenvalólét egzisztenciális analitikáján keresztül közelíthető meg; azonban, mivel a Lét ennek a hermeneutikai folyamatnak egyszerre alapja és tárgya, maga a folyamat lezárhatatlan, mindig is benne állunk a „hermeneutikai körben”. Heidegger tanítványa, Hans-Georg Gadamer, aki az Igazság és módszerben a szellemtudományos igazság létjogosultságának elismerésére szólít fel, a megértés értelmében vett minden emberi tapasztalást a beszélgetés analógiájára gondol el, s mint ilyet, általános érvényűnek tételez. ${ }^{408} \mathrm{~A}$ hermeneutikai tapasztalat univerzalitása így önnön korlátolt lehetőségeinek tapasztalatát is jelenti, az emberi megértés lehetőségének határoltsága így nem jelenti a hermeneutikai tapasztalat határoltságát is, mondja Gadamer. A beszélgetés befejezhetetlensége, a hermeneutikai kör lezárhatatlansága szerinte elegendő garanciája a „logocentrizmus” elkerülésének, amennyiben az „egzisztencia” jövőbe-vetülő, önmaga folyamatos megértésében létező fogalmának jelentősége Gadamer szerint túlmutat a jelenvalólét fakticitásának fogalmáén. ${ }^{409}$ A párbeszéd tehát mint a nyelv alapfenoménje jelenik meg, Gadamer ugyanakkor beismeri, hogy az individuum maga kifejezhetetlen, a dialogikus megértés nyelvisége tehát valóban problematikus. Derrida azon vádjára, mely szerint Heidegger „egzisztenciálhermeneutikája” a logocentrizmus büvkörében ragad,

\footnotetext{
${ }^{408}$ Vö. Hans-Georg Gadamer: Igazság és módszer. Ford. Bonyhai Gábor. Osiris, Bp., 2003. 449-541.

${ }^{409}$ Hans-Georg Gadamer: „Dekonstrukció és hermeneutika.” In: Alföld. 1997/12. 31-38. o. Online: http://epa.oszk.hu/00000/00002/00024/gadamer.html
} 
amennyiben a lét értelmét mint feltárandó-feltárható logoszt tételezi (Heidegger pont annak állítólagos létfeledettsége miatt bírálja a metafizikát, és az annak csúcspontjaként értett nietzschei filozófiát), Gadamer épp a „határ” heideggeri tapasztalatának radikalitását hozza fel ellenérvként. Heidegger ugyanis a Létet nem mint a minden pillanatban feltáruló értelmet érti, hanem mint azt, ami a megmutatkozásban egyúttal vissza is tartja, elrejti magát; megértésének-értelmezésének tehát nem lehet vége. Gadamer ehhez hozzáteszi: az értelmezési feladat csak akkor áll elő, ha a szöveg maga elő-áll, elénk áll, adódik, átadja magát az értelmezésnek, ugyanakkor a heideggeri értelemben meg is vonja magát attól. ${ }^{410}$ „Az interpretáció az, amely az ember és a világ között megteremti a tökéletessé soha nem tehető közvetítést, s ennyiben ez az egyetlen valódi közvetlenség és adottság, hogy valamit valamiként értünk meg". "A $\mathrm{A}$ gadameri hermeneutika számunkra talán legjelentősebb gondolata, hogy a müalkotás létmódjaként a játékot, mint a müalkotás megértésekor bekövetkező „egzisztenciálontológiai léttörténés” lényegét mutatja fel. A német „Spiel” [játék] szó etimológiai elemzése ${ }^{412}$ még plasztikusabbá teszi a játéknak azt a létezése célját saját magában hordozó, ide-oda fickándozó, táncoló jellegét, amit Gadamer a gondolat mozgásának esetében is érzékeltetni szeretne a megértés folyamatán belül. A játék emellett elsősorban ,játszottság”, ahol a játszó, kockára téve saját pozícióját, úgyszólván „,belemegy a játékba”. Ahogyan a játék saját valóságába integrálja a játszót, úgy a műalkotás (esetünkben a szöveg) is átváltozás: ontológiai értelemben átváltoztatja saját magát és a befogadót is. ${ }^{413} \mathrm{De}$ hova tünik ekkor a „,hermeneutikai tudat” egysége? Amennyiben az „egzisztenciálontológiai léttörténés” valóban megtörténik, méghozzá minden megértésben, akkor nem fenyegeti-e a „hermeneutikai tudatot” az „esztétikai tudattá”414 való kvázi-visszaminősülés veszélye? Nem válik-e a megértő tudata végül mégis „kísérletek és kísértések örvénylő maszkjátékává"? ${ }^{415} \mathrm{Az}$ interpretáció, és az egyáltalában vett megértés Nietzschénél, mint láttuk, mindig értelemadás, nem pedig valamely előzetesen adott értelem megtalálása, felmutatása, vagy éppen a tőle passzív módon elszenvedett hatás.

\footnotetext{
${ }^{410}$ Vö. Hans-Georg Gadamer: „Szöveg és interpretáció.” Ford. Hévizi Ottó. In: Szöveg és interpretáció. Szerk. Bacsó Béla. Cserépfalvi, Bp., 1991, 17-41. o.

${ }^{411}$ U. ott 24. o.

${ }^{412}$ Ld. IM 135. o. „Összhangban van ezzel a Spiel [játék] szó eredeti jelentése is, a tánc [...]A mozgásnak, mely játék, nincs célja, ahol befejezödne, hanem állandó ismétlödésben újul meg."

${ }^{413}$ Vö. IM 133-142. o.

${ }^{414}$ Gadamer a modern „esztétikai tudatot” érintő bírálatának lényege, hogy az szubjektivizálja a műalkotás tapasztalatát, így minden esetben korlátolt, szemben a „hermeneutikai tudattal”, amely tisztában van saját történetiségével, és amely épp ezen történetiség révén biztosítja az említett „létgyarapodást”. „Az esztétikának fel kell oldódnia a hermeneutikában" - mondja. (IM 196. o.)

${ }^{415}$ Hans-Georg Gadamer (1997) 31-38. o.
} 
Heidegger azt állítja, hogy a metafizika egységes, átfogó jellegéből adódóan Nietzsche gondolatainak értelmezésekor is egy tételezett egység gondolatát kell alapul vennünk, mely egység alapja a gondolkodás mint egzisztenciálé egysége. Tudvalevő, hogy Heidegger „metafizika” alatt voltaképpen magát a filozófiát érti, amely csak önmagából határozható meg, és amely mint filozofálás, ,az ember végső kimondása és párbeszéde” ${ }^{416}$ Korábban már jeleztük polémiánkat Biczó Gábor interpretációjával szemben, aki szerint a történetiség problémáját, mely a korai, görög tárgyú müvekben etikai és ontológiai értelemben is gondot okoz Nietzschének, a „történelemfeletti” szemlélet második Korszerütlen elmélkedésben ismertetett opciója oldja fel. ${ }^{417}$ Úgy véljük, Biczó értelmezése túlságosan sokat köszönhet a „faktikus jelenvalólét” heideggeri koncepciójának, mely azonban távolról sem esik egybe Nietzschének a „történelemfeletti” szemléletről alkotott elképzelésével. Biczó szerint ugyanis a „történelemfeletti” perspektívában az ember „,a világot a totális jelenlét örökkévalóságának egységeként szemléli”, 418 heideggeri terminussal élve azonosul „a létező totalitásával”. Megismételjük a korábbiakat: egyetértünk azzal, hogy Nietzsche korai időfelfogásának két legfontosabb aspektusa az általa kiemelt hübrisz-problematika, illetve az idő-konstitúció kérdése (mely már közvetlenül mutat az öntudat problémájára is). Vitába szállnánk azonban Biczóval a következő pontokon: 1. Nietzsche már A tragédia születésében kijelenti: a létezés csakis esztétikai jelenségként igazolható. A keletkezés morális problémája a Filozófia a görögök tragikus korszakában címü írásban kerül kifejtésre, ahol is Nietzsche megállapítja: míg Anaximandrosznál a keletkezés még valóban etikai probléma, maga az ős-bűn, addig Hérakleitosznál a keletkezés, és vele együtt a létezés is elveszíti bünös jellegét. Nietzsche ezzel kapcsolatban nagyon is egyértelmüen fogalmaz:

Van-e bün, jogtalanság, ellentmondás, szenvedés ezen a világon? Igen, kiáltja Hérakleitosz, de csak a korlátolt ember számára, aki a dolgokat külön-külön és nem együtt szemléli, ám nincs a contuitív istennek; számára minden ellentét harmóniába egyesül [...] Egyedül a müvész és a gyermek játéka jön létre és múlik el, épül és pusztul örökké azonos ártatlansággal, mindenfajta morális járulék nélkül ezen a földön. És ahogyan a gyermek és a müvész játszik, úgy játszik az örökké eleven tüz is, épít és rombol ártatlanul - és ezt a játékot játssza az Aión önmagával. [...] Egy pillanatig elégedett, aztán ismét egyfajta vágy fogja el, ahogyan a művészt is ez kényszeríti alkotásra. Nem gonoszság, hanem újraéledő játékösztön hoz létre más világokat. ${ }^{419}$

\footnotetext{
${ }^{416}$ Martin Heidegger: A metafizika alapfogalmai. Ford. Aradi László, Olay Csaba. Osiris, Bp., 2004, 26. o.

${ }^{417}$ Ld. jelen értekezés 20-22. oldalát.

${ }^{418}$ Biczó (2005) Online: http://filozofia.ektf.hu/koteteink/2005.html

${ }^{419}$ FGTK 90-91. o.
} 
2. Figyelembe véve, hogy a preszókratikusokkal foglalkozó, azonban sajnálatos módon töredékben maradt írás nagyjából a második Korszerütlennel egy időben íródott, célszerübb lehet azt feltételezni, hogy a keletkezés eredendő bünösségének a tragédiakönyvben még markánsan jelenlévő gondolatát Nietzsche a Hérakleitosz-interpretációval kvázi revideálta. Ennek fényében azonban a történelemfeletti koncepciójában kifejtett idő-szemlélet a keletkezés-probléma etikai rehabilitációját követő, immár tisztán esztétikai temporalitáskonstrukció kiforrott, és ami még ennél is jóval fontosabb: immáron valóban és vállaltan nietzschei kifejtése.

\section{2. b. A heideggeri kritika problematizálása}

A metafizika destrukciójának feladata, melyet Heidegger maga elé tüzött, az ontológiai differencia kimondásától tehát elsősorban az „ontoteologikus” gondolkodás korrekcióját, azaz a nominalizmus és a logocentrizmus kritikáját várja. A Lét és idő Heideggere számára tehát a jelenvalólét tulajdonképpeniségében, mely mindig „világbanvaló-létet” jelent, már mindig is a létmegértés módján van. Az emberi élet mint világban-lét az egészben-lét felé való útonlét, az átmenetben megnyilvánuló végesség, melyben azzá válunk, akik vagyunk: végességünk csak végessé válásunkban, a jelenvalólétre való elszigetelődésünkben van. Ennek előfeltétele az „egészben” általi megragadottság, a hozzá való ủzöttség, a honvágy, mely a filozofálás alaphangoltsága; maga a metafizika pedig az emberi jelenvalólét alaptörténése.Az előző fejezetben részletesen vizsgáltuk, pontosan hogyan is konstruál onto-teológiát Heidegger értelmezésében az öt nietzschei „alapszó”. Eszerint lényegében a következőről lenne szó: a „nihilizmus”, mint válságtünet, azt a pillanatot jelzi, mikor a „hatalom akarása” mint az „értékek átértékelésének” alapelve önmaga meghaladásában teljesedik be, vagyis amikor az új értékek tételezése a metafizika egy új korszakát megnyitván, egyúttal teljességgel felszámolja az addig elfogadott értékeket. A „hatalom akarása” „látszani-engedi” a „létező igazságát az egészben”, és ő maga is ebben (és mindig ugyanebben) a látszani-engedésben teljesedik ki. Az „emberfeletti ember”: a „hatalom akarásának” megtestesülése; amennyiben az „igazság” eleve csak az ember számára van értékként, így a „létező igazsága az egészben” csak az emberben és az ember által válhat teljessé. A „hatalom akarásának”, vagyis az értéktételezés alapelvének ez a „létező igazságát 
az egészben” látszani-engedéseként való beteljesedése maga a szükségszerü ,igazságosság”, melynek értelmében a „létező igazsága az egészben” újra és újra, örökké előhívatik az elrejtettségből. A „hatalom akarása” tehát az „örök visszatérés” gondolatának értelme.

Csak ahol a létező mint olyan hatalomra irányuló akarat, és a létező az egészben ugyanannak örök visszatérése, ott lehetséges végbemennie az eddigi emberfeletti ember valódi nihilista megfordításának, és ott kell az emberfeletti embernek a hatalomra irányuló akarat feltétlen szubjektivitása által a maga számára fölállított legföbb szubjektumnak lennie. ${ }^{420}$

Heidegger értelmezésében tehát a nietzschei perspektivizmus voltaképpen a létezőnek állítóként, számítóként, azaz értékelőként való felfogása, ahol is a létező feltétlen, abszolút szubjektummá tételében és a hatalomra irányuló akarat teljességében a Lét mint a lehető legüresebb és egyszersmind leggazdagabb fogalom jelenik meg; ez pedig az ontológiai differencia figyelmen kívül hagyását, végső soron metafizikus gondolkodást jelent. A nietzschei metafizika alfája és ómegája, eredete és végpontja tehát a „hatalom akarása”, mely örökké ugyanakként visszatérve folyamatosan újratermeli az eredendő káoszt, amely Nietzsche szerint „kezdettől fogva a világ összkaraktere”, ${ }^{421}$ de pusztán annyiban, amennyiben a legfőbb értékek időről időre elértéktelenednek, hogy új értékeknek adhassák át a helyüket. A kaotikus jelleg tehát se többet, se kevesebbet nem jelent, mint a Lét és Igazság azon eredendő összetartozását a létezőben, melyet az önmagát akaró akarat örök visszatérésében újra és újra előhív az elrejtettségből. A nihilizmus a metafizika egy korszaka, mondja Heidegger, de nem egyszeri; éppen a nihilizmus periódusainak visszatérése tartja fenn a világ kaotikus karakterét, melyben az ontológiai differencia elfeledve maradhat. A nihilizmus, vagyis az értékek elértéktelenedése csak a hatalom akarása révén teljesedhet be, méghozzá úgy, hogy az akarás legmagasabb fokán a nihilizmusnak minden fennálló érték megsemmisítését is akarnia kell. Ám ebben a megsemmisíteni-akarásban is pusztán önmagát igenli - és ez a folyamat időröl időre megismétlődik, ugyanannak örök visszatérésében, a hatalom önmagához való örök visszatérésében. A nietzschei filozófia, mondja Heidegger, az örök visszatérés és a hatalom akarása elgondolása révén a metafizikát mint a „létező igazságát az egészben” elgondoló gondolkodást teljesítette be. - Ezzelszemben Nietzsche már 1881

\footnotetext{
${ }^{420}$ Heidegger (1994d) 53. o.

${ }^{421}$ Vö. VT 109. §
} 
őszén a következőket veti papírra: „megszentségtelenítés már az is, hogyha valami egészet mondunk célnak. Az ideál egésze túl nagy - nem szakíthatsz róla, csak egy-egy sugarat”... ${ }^{422}$

Mint azt a bevezetésben már jeleztük, úgy véljük, hogy Heidegger interpretációja részleteiben legtöbbször roppant pontos és lényeglátó. Amikor ugyanis az ontológiai differencia gondolatának vezérfonalára füzi fel Nietzsche-interpretációját, maga is a differencia-filozófia terminusaiban gondolkodik. Azt állítja, hogy Nietzsche filozófiája, melyet ő a „hatalom akarása” gondolatában lát kulminálni, a metafizika „ontoteológiai” tradíciójának, a „létező igazságát az egészben” folyamatosan az elrejtetlenségbe hozó, és ezáltal az ontológiai differenciát a feledésben tartó hagyománynak a betetőzése. Végkövetkeztetése azonban, mely egyszersmind előfeltevése is, úgy véljük, téves. Heidegger maga is arra a konklúzióra jut az ontológiai differencia, vagyis a Lét és létező eredendő különbségének gondolata kapcsán, hogy az voltaképpen kimondhatatlan, sőt, elgondolhatatlan az alapvetően nyelvileg kommunikáló és gondolkodó, tehát nem csak létében, hanem megismerésében is végességre kárhoztatott ember számára. Azt állítja, a nyugati ember már mindig is az „ontoteológia” nyelvét beszélte. Az ontológiai differencia elfeledése pedig csak úgy lehetséges, ha az, ami „,a létező igazságaként az egészben” az elrejtetlenségbe jön, nem más, mint maga a Lét. Ily módon maga Heidegger mondja ki: az ontológia reprezentációt előfeltételez, méghozzá mint saját általában vett lehetőségének feltételét. Felmerül tehát a kérdés: mi lehet az oka annak, hogy Heidegger előbb felismeri, majd a „hatalom akarását” mint a „létező igazságát” (ti. a Létet) az elrejtetlenségbe hozó gondolat „ontoteológiai” jellegét állítva szinte „letagadja” az ontológiai differencia jelenlétét az örök visszatérésben? ${ }^{423}$ A rosszindulatú elemző ezen a ponton azt gyaníthatná, hogy Heidegger pusztán azért vitatta el Nietzschétől az ontológiai differencia felismerésének eredményét, hogy azt a maga számára őrizhesse meg. Egy ilyen magyarázat azonban, amellett, hogy messzemenően tiszteletlen és túlságosan is merész volna, még csak nem is lenne eléggé megnyugtató a számunkra. Arra

\footnotetext{
${ }^{422}$ ÚF 3[19] / KSA 9.643

${ }^{423}$ Jefferey Kinlaw érdekes problémára világít rá Heidegger érvmenetében. Azt állítja, Heidegger önellentmondásba keveredik az „Isten halott” mondás kapcsán. Heidegger szerint a metafizikus tradícióban az értékelés mindig szubjektív, mert a „létfelejtésben” lévő létező mindig önmagát helyezi előtérbe a reprezentációban, nem pedig a reprezentáltat (vagyis magát a Létet); így mindig elő is állítja önmagát a reprezentációban. Magát a hatalom akarását az általában vett értéktételezés alapmozgásaként mutatja fel, így ez egyúttal a nyugati metafizika betetőzését is jelenti. Mindennek előfeltétele az „Isten halott” kimondása, melynek következtében az ember számára elérhetővé válik az értéktételező pozíció. Ugyanakkor Heidegger azt is állítja, hogy a Dasein számára a Léttel/Istennel való autentikus „találkozás” is csak ezen felszabadulás révén válik lehetségessé; ez az a „visszalépés”, amely újra felfedi az ontológiai differenciát. De hogyan jelenthetné be ugyanaz a mondat a metafizika lehetőségét - és egyszersmind a végét is? (Ld. Jeffery Kinlaw: „Heidegger on Nietzsche's Word and Overcoming Ontotheology.” In: Heidegger \& Nietzsche. Ed. Babette Babich et al. Rodopi, Amsterdam-New York, 2012. pp. 59-76.)
} 
ugyanis még mindig nem adna magyarázatot, hogy vajon miért nem sikerült a jórészt heideggeri alapokra építő differencia-gondolkodásnak kielégítő bizonyossággal tisztáznia a metafizika meghaladására tett nietzschei kísérlet sikerének, vagy épp sikertelenségének kérdését. És ez az a pont, ahol Nietzsche filozófiája először válhat igazán „gyanússá”. Úgy véljük ugyanis: fennáll annak a lehetősége, hogy Nietzsche már jóval „hivatalos” filozófussá válása előtt felismerte a metafizika meghaladásának lehetetlenségét; mégpedig pontosan azon egyszerű oknál fogva, amelyre Heidegger is felhívja a figyelmünket. Egy fennálló rendszer megdöntése ugyanis csak úgy lehetséges, ha harcolunk ellene; méghozzá, egyelöre nem lévén más lehetőségünk, a saját területéről származó eszközökkel. Heidegger végső soron úgy magyarázza Nietzschét, mint aki felismerte ezt a lehetetlenséget, és ezért döntött úgy, hogy visszafordul a hagyományba és azon belül marad. Mi tehát valóban nem azt állítjuk, hogy Heidegger félreértette Nietzschét; sokkal inkább azt gyanítjuk, hogy egyszerüen visszazárta palackjába az örök visszatérés félelmetes szellemét. Mindez azonban egyelöre puszta gyanú, melyet most meg kell kísérelnünk alátámasztani - de, mint látni fogjuk, semmiképpen sem igazolni.

Ahogyan azt az első fejezetben érzékeltetni próbáltuk, értelmezésünkben Nietzsche emberfeletti embere, az immár tökéletesen „szabad” szellem, éppen a feltételezettségre mint olyanra, az értékelés meglévő szempontjainak átvételére, a metafizika definitív jellegére és fundacionalista törekvéseire mond nemet. Szabadságát, mely rombolásra és teremtésre egyaránt feljogosítja - tehát éppen, hogy nem metafizikai értelmü -,nem azabszolút, a totális, az átfogó értelmében vett feltétlenség jellemzi, sokkal inkább az a feltétel-nélküliség, amely egyedül az emberfeletti ember sajátja, aki képes igent mondani az örök visszatérés szörnyü gondolatára. Az örök visszatérésben a lét mindig éppen itt és éppen most kezdődik, a „lét ugyanegy háza” örökké épül, folyamatos keletkezésben, létrejövésben [Werden] van. A vidám tudomány egyik ismert szöveghelyén Nietzsche a következő kérdést teszi fel: „Ha e gondolat úrrá lenne rajtad, megváltoztatna teljes valódban, sőt talán föl is örölne, a mindenre és minden dolgokra vonatkozó kérdés: »akarod-e mindezt még egyszer és számtalanszor újra?« nehezedne legsúlyosabb teherként cselekvésedre?" ${ }^{24}$ Erre a kérdésre pedig egyedül az embert fölülmúló ember képes örök igennel felelni, tetteiben örökké visszatérni, mert ő az, aki „olyannak képzeli a valóságot, amilyen: megvan hozzá az ereje - nem idegenedett, nem távolodott el a valóságtól, mert ez az emberfajtamaga a valóság, magában hordozza annak

${ }^{424}$ VT 341. § 
minden borzalmát es kérdésességét". ${ }^{425}$ Tatár György remek elemzésében megállapítja, hogy ez esetben a kérdés-formának is meghatározó szerepe van, nevezetesen az, hogy kiemelje az örök visszatérés gondolatának kinyilatkoztatás-jellegét: minden új kérdés feltevése egy olyan új világot előlegez, mely eredendőbb magánál a kérdésnél. Tatár konklúziója: „az örök visszatérés gondolata Nietzsche számára a filozófiai hagyomány leküzdésének eszköze, mert a gondolat konzekvenciái szinte automatikusan megakadályozzák a metafizika kiinduló fogalmainak létrejöttét." ${ }^{26}$ A kérdés-jelleg jelentősége, mint a későbbiekben látni fogjuk, jelen értekezés számára is felbecsülhetetlen.

Heidegger nem csak a Nietzsche-monográfiában, de az Azonosság és differenciában is érvelése középpontjába helyezi $A$ hatalom akarása Förster-Gast féle kompilációjában 617-es számmal szereplö ${ }^{427}$, a harmadik könyv „A hatalom akarása mint megismerés” címü alfejezetet záró töredéket. Ennek, a már a szövegképre pillantván is szembetünő „hangsúlyeltolódások” okán, mind az eredeti változatát, mind pedig a magyar fordítását szükségesnek tartjuk teljes terjedelmében idézni. Azokra a Förster-Gast által nem kiemelt kifejezésekre, illetve mondatrészekre gondolunk ugyanis, melyeket Nietzsche maga fontosnak tartott megkülönböztetni szövegének egészén belül. Mindez majd akkor lesz érdekes, mikor a szövegek olvasása után felidézzük, hogyan interpretálta Heidegger a töredéket. Az eredeti, német nyelvű szövegben a Nietzsche által eszközölt kiemeléseket dőlt betűvel szedjük, illetve így járunk el a második szöveg esetében is - vagyis a kompilációra támaszkodó magyar fordításban - ott, ahol a „szerkesztők” megtartották a kiemelést. Azon részeket, melyek hangsúlyozásáról ők „megfeledkeztek”, a magyar változatban vastagon szedjük. Elsőként tehát következzen a töredék a kéziratban szereplő formában, ahogyan a Colli-Montinari féle kritikai összkiadásban is megjelent, majd pedig a Förster-Gast kompilációt alapul vevő magyar fordítás. ${ }^{428}$

Dem Werden den Charakter des Seins aufzuprägen - das ist der höchste Wille zur Macht.

Zwiefache Fälschung, von den Sinnen her und vom Geiste her, um eine Welt des Seienden zu erhalten, des Verharrenden, Gleichwerthigen usw.

Daß Alles wiederkehrt, ist die extremste Annäherung einer Welt des Werdens an die des Seins: Gipfel der Betrachtung.

\footnotetext{
${ }^{425} \mathrm{EH} 128$. o.

${ }^{426}$ Tatár (1989) 169. o., illetve vö. 9-38. o.

${ }^{427}$ KSA 12.312

${ }^{428}$ Friedrich Nietzsche: A hatalom akarása. Minden érték átértékelésének kisérlete. Ford. Romhányi Török Gábor. Cartaphilus, Bp., 2002.
} 
Von den Werthen aus, die dem Seienden beigelegt werden, stammt die Verurtheilung und Unzufriedenheit im Werdenden: nachdem eine solche Welt des Seins erst erfunden war.

Die Metamorphosen des Seienden (Körper, Gott, Ideen, Naturgesetze, Formeln usw.)

»Das Seiende« als Schein; Umkehrung der Werthe: der Schein war das Werthverleihende -

Erkenntniß an sich im Werden unmöglich; wie ist also Erkenntniß möglich? Als Irrthum über sich selbst, als Wille zur Macht, als Wille zur Täuschung.

Werden als Erfinden Wollen Selbstverneinen, Sich-selbst-Überwinden: kein Subjekt, sondern ein Thun, Setzen, schöpferisch, keine »Ursachen und Wirkungen.«

Kunst als Wille zur Überwindung des Werdens, als »Verewigen«, aber kurzsichtig, je nach der Perspektive: gleichsam im Kleinen die Tendenz des Ganzen wiederholend

Was alles Leben zeigt, als verkleinerte Formel für die gesammte Tendenz zu betrachten: deshalb eine neue Fixirung des Begriffs »Leben«, als Wille zur Macht

Anstatt »Ursache und Wirkung« der Kampf der Werdenden mit einander, oft mit Einschlürfung des Gegners; keine constante Zahl der Werdenden.

Unbrauchbarkeit der alten Ideale zur Interpretation des ganzen Geschehens, nachdem man deren thierische Herkunft und Nützlichkeit erkannt hat; alle überdies dem Leben widersprechend.

Unbrauchbarkeit der mechanistischen Theorie—giebt den Eindruck der Sinnlosigkeit.

Der ganze Idealismus der bisherigen Menschheit ist im Begriff, in Nihilismus umzuschlagen — in den Glauben an die absolute Werthlosigkeit das heißt Sinnlosigkeit ...

Die Vernichtung der Ideale, die neue Öde, die neuen Künste, um es auszuhalten, wir Amphibien.

Voraussetzung: Tapferkeit, Geduld, keine »Rückkehr«, keine Hitze nach vorwärts

NB. Zarathustra, sich beständig parodisch zu allen früheren Werthen verhaltend, aus der Fülle heraus." ${ }^{429}$

\section{[Összefoglalás]}

A levésre a lét karakterét erőszakolni - ez a hatalom legfőbb akarása.

Kétszeres hamisitás, az érzékek és a szellem oldaláról, olyan meglévő világ megőrzése érdekében, mely a kitartóaké és az egyenértéküeké stb.

Hogy minden visszatér: ez a levés világának legszorosabb közelítése a lét világához: a szemlélődés tetőpontja.

A létnek tulajdonított értékekből származik a levés elítélése és a vele való elégedetlenség: miután a létnek e világát először föltalálták.

A létező metamorfózisai (test, isten, eszmék, természeti törvények, képletek stb.)

»A létező« mint látszat, az értékek megfordítása: a látszat volt az értékadó -.

\footnotetext{
${ }^{429}$ Kiemelések az eredeti, német nyelvű szövegben, L. E.
} 
Magánvaló megismerés a levésben lehetetlen; akkor hogyan lehetséges megismerés? Önmagában való tévedésként, a hatalom akarásaként, a tévedés akarásaként.

Levés mint feltalálás, akarás, önmegtagadás, önlegyőzés: szubjektum nincs, csak cselekvés, tételezés, kreatívan, semmi »ok és okozat«.

Mủvészet mint a levés leküzdésének akarása, mint »megörökítés«, ám rövidlátó módon, a perspektíva szerint: mintegy kicsiben ismételve az egész tendenciája.

Ami csak életet mutat, azt az egész tendencia kicsinyített képletének kell tekinteni: ezért az »élet« fogalmának új rögzítése a »hatalom akarásaként.«

»Ok és okozat« helyett a levők harca egymással, gyakorta az ellenség bekebelezésével; a levőknek nincs állandó számuk.

A régi eszmék használhatatlansága az egész történés interpretációjához, miután fölismertük ennek állatias eredetét és hasznosságát; minden egyéb az életnek ellentmondó.

A mechanisztikus elmélet használhatatlansága - az értelmetlenség benyomását kelti.

Az eddigi emberiség egész idealizmusa azon a ponton van, hogy nihilizmusba csap át - az abszolút értéktelenség vagy értelmetlenség hitébe...

Az eszmények megsemmisülése, az új sivatag: az új müvészetek, hogy mindezt kibírjuk, mi amphibiák (kétéltüek - a ford.).

Előfeltevés: bátorság, türelem, nincs »visszaút«, nem kell sietni előre.

N. B. Zarathustra tulajdon bőségéből kiindulva állandóan parodisztikusan viselkedik minden korábbi értékkel szemben." 430

Heidegger a monográfia első kötetében „A hatalom akarása mint művészet” címü fejezet negyedik alfejezetének a következő címet adja: „A hatalom akarása, az örök visszatérés és az átértékelés egysége". 431 Értelmezése szerint az örök visszatérésben a hatalom akarása tér vissza örökké ugyanakként, méghozzá a „létező igazságaként az egészben”; így tehát a hatalom akarása nem csak az örök visszatérés, de az átértékelés lehetőségét és egyszersmind szükségszerüségét is magában foglalja. A „levés”, vagyis a folyamatos keletkezés Nietzschénél eszerint azt jelenti, hogy a keletkező, vagyis a létező alapkaraktere a hatalom akarása. Heidegger szintén a Förster-Gast kompilációt idézi: „összegzés: a levésre a lét karakterét erőszakolni - ez a hatalom legfőbb akarása”, majd a második mondat kihagyásával így folytatja: „hogy minden visszatér: ez a levés világának legszorosabb közelítése a lét világához: a szemlélődés tetőpontja. ${ }^{״ 32} \mathrm{Ez}$ első látásra valóban alátámasztja a heideggeri olvasatot, azonban ha a gondolatmenet két pontját összekötő (vagy éppen elválasztó) második

\footnotetext{
${ }^{430}$ HA 617. § (kiemelések a magyar fordításban, L. E.)

${ }^{431}$ NI I:26. „Die Einheit von Willen zur Macht, ewiger Wiederkehr und Umwertung.”

${ }^{432}$ U. ott 27.
} 
mondatot is felidézzük, máris másként fest a helyzet. „Kétszeres hamisítás, az érzékek és a szellem oldaláról, olyan meglévő világ megőrzése érdekében, mely a kitartóaké és az egyenértéküeké stb.” A „kétszeres hamisítást” persze Heidegger sem mulasztja el a metafizikus hagyomány szemére vetni pár oldallal lejjebb, de a mondat konkrét pozíciójának jelentőségét nem veszi figyelembe. Miközben a Nietzsche által 1886 végén papírra vetett szöveget olvassuk, A nem-morálisan fölfogott igazságról és hazugságról címü korai írás szavai kezdenek visszhangozni a fejünkben. A megismerés lehetösége és maga a dolgok lényegét kifejező ,igazság” mint megismerhető és birtokolható fogalom az elbizakodott ember agyszüleménye, mellyel életösztönét szolgálja; így téve önmaga számára valóvá a világot. A „helyes percepció”433 azonban, amint azt Nietzsche már 1873-ban kijelentette, képtelenség. A keletkezés és a lét világa tehát, mondja Nietzsche, az örök visszatérés gondolatában jut a lehető legközelebb egymáshoz ${ }^{434}$ - ez a gondolat azonban nem hogy kimondhatatlan, de az ember számára még elgondolása is csak a kontemplációban lehetséges - minden egyéb feltételezés: erőszak. Majd ismét a metaforikus, plurális igazság gondolata: „a létnek tulajdonított értékekből származik a levés elítélése és a vele való elégedetlenség: miután a létnek e világát elöször föltalálták. A létező metamorfózisai (test, isten, eszmék, természeti törvények, képletek stb.) »A létező« mint látszat, az értékek megfordítása: a látszat volt az értékadó -." Egyedül a keletkezés világa valódi - de nem a létnek a heideggeri értelemben a létezőben látszani-engedett igazsága által, hanem mert maga az értékadás is: látszat. „Magánvaló megismerés a levésben [Werden] lehetetlen: akkor hogyan lehetséges megismerés? Önmagában való tévedésként, a hatalom akarásaként, a tévedés akarásaként. Levés mint feltalálás, akarás, önmegtagadás, kreatívan, semmi »ok és okozat«." Szubjektivizmus-kritika, de nem ontológia: „levés mint feltalálás, akarás, önmegtagadás, önlegyőzés: szubjektum nincs, csak cselekvés, tételezés, kreatívan, semmi »ok és okozat«. [...]Ami csak életet mutat, azt az egész tendencia kicsinyített képletének kell tekinteni: ezért az »élet« fogalmának új rögzítése a »hatalom akarásaként«.” Művészet-filozófia de nem művészet-metafizika: „Művészet mint a levés leküzdésének akarása, mint »megörökítés«, ám rövidlátó módon, a perspektíva szerint: mintegy kicsiben ismételve az egész tendenciája.” Teleológia-kritika és mechanizmus-kritika, de nem az „igazságosság” elve: „»Ok és okozat« helyett a levők harca egymással, gyakorta az ellenség bekebelezésével; a levőknek nincs állandó számuk. [...] A mechanisztikus elmélet használhatatlansága - az

\footnotetext{
${ }^{433}$ NMIH 10. o.

${ }^{434}$ Vö. ÚF 6[7] / KSA 10[646] „a két legföbb filozófiai szempont (amelyekre németek leltek) / a keletkezés, a fejlődés szempontja / a létezés értékének szempontja (...) én döntő módon egyesítettem a kettőt / keletkezik és örökké visszatér minden - nincs menekvés...”
} 
értelmetlenségbenyomását kelti." Rendszer-kritika, de új rendszer igényének bejelentése nélkül: „a régi eszmék használhatatlansága az egész történés interpretációjához, miután fölismertük ennek állatias eredetét és hasznosságát; minden egyéb az életnek ellentmondó.” Metafizika-kritika - a meghaladás célja nélkül: ,az eddigi emberiség egész idealizmusa azon a ponton van, hogy nihilizmusba csap át - az abszolút értéktelenség vagy értelmetlenség hitébe... Az eszmények megsemmisülése, az új sivatag: az új művészetek ${ }^{435}$, hogy mindezt kibírjuk, ${ }^{436}$ mi amphibiák (kétéltüek - a ford.). Előfeltevés: bátorság, türelem, nincs »visszaút«, nem kell sietni elöre. N. B. Zarathustra tulajdon bőségéből kiindulva állandóan parodisztikusan viselkedik minden korábbi értékkel szemben.” Az Élet egyedül a maga teremtette műalkotásként elviselhető az ember számára, egy ilyen élet pedig csak a célszerütlenség értelmében lehet organikus. ${ }^{437}$

Heidegger meghatározó fontosságot tulajdonít a visszatérés momentumának; a „Lét ugyanegy házába” való visszatérést mint az önazonosságba való visszatérést értelmezi. Ennek szellemében elsőként az,,alapelv" kérdését kezdi tárgyalni, amely, mint mondja, az új rendszer számára nélkülözhetetlen, tehát A hatalom akarása harmadik könyvének címét: „Egy új értéktételezés elve”, a következőképp kell érteni: „az új alap, melyből a jövőben az értékelés új módja és típusa sarjad majd, és amelyen nyugszik majd". ${ }^{438}$ Legyen szabad az angol fordítóra hivatkoznunk, aki felhívja a figyelmünket egy elemzői „mulasztásra”: 439 Heidegger az eredeti cím [Prinzip einer neuen Werthsetzung] határozatlan névelőjét [einer] Heidegger határozott névelöre [der] cseréli:

Was Nietzsche eigentlich und vor allem anderen wollte: die Weise, wie die Werte gesetzt werden, neu begründen, einen neuen Grund dafür legen. Die Überschrift des dritten Buches: »Prinzipder neuen Wertsetzung« muß daher, will man etwas von dem begreifen, was hier gedacht wird, im folgende Sinne verlesen werden: Der

\footnotetext{
${ }^{435}$ Vö. ÚF 1[162] / KSA 9.503 sk. „A megismerés föltétele az élet. Az élet föltétele a tévedés, mégpedig a legmélységesebb, legalapvetőbb tévedés. A tévedést nem szünteti meg, hogyha nem tudunk róla! Nincs ebben semmi keserü! Szeretnünk és ápolnunk kell a tévedést, az a megismerés anyaméhe. A müvészet mint a téboly ápolása - a kultuszunk. A megismerés kedveért szeretni és óvni az életet, az élet kedvéért szeretni és óvni a tévedést, a képzelgéseket. Esztétikai jelentőséget adni a létnek, tenni róla, hogy egyre inkább ízlésünk szerint való legyen - ez a megismerés minden szenvedélyének alapföltétele."

${ }^{436}$ Vö. PE 19[35] / KSA 7.427 sk. „A tragikus filozófus számára az kerekíti ki a létezés képét, hogy a metafizikum csakis antropomorf alakban jelenik meg. (...) Akarnunk kell az illúziót, ebben áll a tragikum.”

${ }^{437}$ Vö. PE 19[23], illetve 19[50] / KSA 7.423, illetve 7.436. „A filozófus dolga, hogy fölismerje, amire szükség van, a művészé pedig, hogy megalkossa azt. (...) Ebbe a hiányba építi bele a maga világát [ti. amire szükség van, L. E.]. (...) az organikussal egyszersmind kezdetét veszi a müvészi is.”

${ }^{438}$ NI I:40.

${ }^{439}$ Ld. a csillaggal jelölt részt itt: Martin Heidegger: Nietzsche. Volumes One and Two. Trans. David Farrell Krell. Harper\&Row, San Francisco, 1991, p. 31.
} 
neue Grund, aus dem die Weise und Art künftig entspringt, auf dem sier ruht. Wie ist dieser Grund zu fassen? Wenn es sich in dem Werk, wie der Titel sagt, um den Willen zur Macht handelt und wenn das dritten Buch das Grundlegende und Aufbauende bringen soll, dann kann dieses Prinzip der neuen Wertsetzung nur der Wille zur Macht sein. / Amit Nietzsche tulajdonképpen és mindenekelőtt szeretett volna: újra megalapozni a módot, ahogyan az értékeket megadják, új alapot találni a számára. A harmadik könyv címét: „azúj értékmeghatározás elve”, ha valamelyest meg akarjuk érteni, amiről itt szó van, a következőképpen kell olvasnunk: $a z$ új alap, amelyből ez a mód és ez a müvészet a jövőben ered, amelyen ezek nyugszanak. Hogyan ragadhatjuk meg ezt az alapot? Ha a mü, ahogyan a címe mondja, a hatalom akarásáról szól, és ha a harmadik könyv az alapvetést és a felépítendőthivatott megadni, akkor az új értékelés ezen alapelve csak a hatalom akarása lehet. ${ }^{440}$

Ha tehát, mondja Heidegger, ahogy a mü [ti. a Förster-Gast féle kompiláció] címe is mutatja, a hatalom akarása a témánk, és ha a harmadik könyv az alapvetést és a felépítendőt jelenti be, akkor az új értéktételezés elvének új alapja csak a hatalom akarása lehet. Azzal kapcsolatban eleve nincs kétsége, hogy Nietzschének kifejezett célja volt $a z$ új „világrend” megalapozása, ennek alátámasztására szintén Nietzschét idézi. ${ }^{411}$ Bár Heidegger, bizonyára véletlenül, elmulasztja megjelölni az idézet pontos helyét, a szemfüles angol fordító itt is segítségünkre siet: valószínüleg a kompilációban 461. számmal felvett aforizmára utal; ${ }^{442}$ ez esetben viszont félrefordította Nietzschét, és az eredeti szövegben szereplő „értékek új rendje” helyett „,új világrendről” beszél. Ez az apró „,baki” azonban hihetetlenül fontos következményekkel jár; ugyanis az értékek új rendjében lehet „alapelv” a változás, a „világ” azonban, amint láttuk, folyamatos változásként - legalábbis a metafizikai gondolkodás keretein belül - lényegileg elgondolhatatlan. Nietzsche egészen pontosan így fogalmaz:

Elég kimutatnunk, hogy a morális amorális, abban az értelemben, ahogy az amorálist egészen mostanáig elítéltük. Ha így megtört az eddigi értékek zsarnoksága, és elpusztítottuk a „való világot”, az értékek új

\footnotetext{
${ }^{440}$ NI I:40-41. (kiemelések tölem, L. E.)

${ }^{441}$ NI I:39-40.,,was Nietzsche eigentlich und vor allem anderen wollte: die Weise, wie die Werte gesetzt werden, neu begründen, einen neuen Grund dafür legen. Die Überschrift des dritten Buches: »Prinzip der neuen Wertsetzung « muß daher, will man etwas von dem begreifen, was hier gedacht wird, im folgende Sinne verlesen werden: Der neue Grund, aus dem die Weise und Art künftig entspringt, auf dem sier ruht. Wie ist dieser Grund zu fassen? Wenn es sich in dem Werk, wie der Titel sagt, um den Willen zur Macht handelt und wenn das dritten Buch das Grundlegende und Aufbauende bringen soll, dann kann dieses Prinzip der neuen Wertsetzung nur der Wille zur Macht sein."

${ }^{442}$ KSA 13.319 „Es genügt nachzuweisen, daß auch die Moral unmoralisch ist, in dem Sinne, in dem das Unmoralische bis jetzt verurtheilt worden ist. Ist auf diese Weise die Tyrannei der bisherigen Werthe gebrochen, haben wir die »wahre Welt« abgeschafft, so wird eine neue Ordnung der Werthe von selbst folgen müssen. NB NB. Die scheinbare Welt und die erlogene Welt: ist der Gegensatz: letztere hieß bisher die »wahre Welt«, die »Wahrheit«, »Gott«. Diese haben wir abzuschaffen."
} 
rendjének önmagától kell elkövetkeznie. [Nota bene! Nota bene!] A látszólagos világ és a hazudott világ - az ellentét: utóbbit hívták eddig a „való világnak”, „igazságnak”, „Istennek”. Ezeket kell elpusztítanunk. ${ }^{443}$

Az „értékek új rendje” eszerint sem általában vett rendszert, sem metafizikus rendszert nem jelent. Heidegger úgy véli: „ami Nietzschét illeti”, a terminológia-használat távolról sem egyértelmű. Mikor ugyanis a valóság egységére gondol, a „világ” [die Welt] vagy „létezés” [das Dasein] terminusokat alkalmazza, az azonban nem egyértelmű, hogy a létezésnek van-e jelentése, és ha igen, mi az. Emellett hasonló jelentéstartománnyal bír Nietzschénél az „élet” [das Leben] kifejezés is, ami Heidegger számára igen zavaró, hiszen, mint mondja, az ember és állat is „él”, de csak az ember „,egzisztál” a „Dasein” értelmében. A Dasein-Welt-Leben hármasság valóban jelen van $A$ vidám tudományban (,a lét [Leben]örök homokórája”; a „létezés” [Dasein] „értéke” / „,értelme”; „egy lényegileg mechanikus világ [Welt] lényegileg értelmetlen világ volna"444) ez azonban a mi nézőpontunkból egyáltalán nem tűnik zavarónak. Heidegger problémája a következő: az „élet” általános karaktere az „erő”, amely azonban szerinte Nietzschénél hangsúlyozottan nem-fizikai terminusokban értendő. Azok, akik Nietzsche filozófiáját görög mintára a statikussal szembenálló dinamikus gondolkodásmódként interpretálják, mérhetetlen kavarodást okoznak; hiszen ezek pusztán a gondolkodás fizikai-technikai területén alkalmazhatók, nem pedig a metafizikában, ahova az a hatalom akarásaként értett „erő” nietzschei koncepciója tartozik. Az erő korlátolt, hiszen ha végtelenül növekedhetne, akkor vajon mi táplálná? - teszi fel a kérdést, ismét csak Nietzschét idézve. Abból, hogy Nietzsche hangsúlyozza: a végtelenség összeférhetetlen az erő gondolatával, Heidegger szerint egyenesen következik, hogy az erő valami meghatározott, definiált; méghozzá az ,igazság” értelmében. Heidegger Nietzsche következő soraira hivatkozik: „a vég nélkül megújuló keletkezés visszatérés, tehát végtelenül növekvő erőt igényelne. De miből származhatna ez [az erő, L. E.]! Honnan a felesleg, ami táplálja! A feltevés, hogy a mindenség egy organizmus, ellentétes az organikus lényegével."445 Tudjuk, hogy Nietzsche komolyan foglalkozott az „organikus” problémájával; így a fentiek szerintünk a következőképp értendők: saját koncepciója az organizmusról meghaladja az organikus hagyományos, zárt egységként értett eszméjét. A Zarathustra második részének keletkezése idején így gondolkodik: ,az ösztönök felsogásom szerint magasabb rendű szervek [Organe]:

\footnotetext{
${ }^{443} \mathrm{HA} 461 . \S$

${ }^{444}$ Ld. VT 341.; 357. és 373. §

${ }^{445}$ Vö. KSA 9.525. „Das unendlich neue Werden ist ein Widerspruch, es würde eine unendlich wachsende Kraft voraussetzen. Aber wovon sollte sie wachsen! Woher sich ernähren, mit Überschuß ernähren! Die Annahme, das All sei ein Organism, widerstreitet dem Wesen des Organischen.” (kiemelés tőlem, L. E.)
} 
egymással összenőtt, egymást kölcsönösen organizáló, tápláló cselekvések, érzetek és érzelmi állapotok - [...] Ami lényeges az összes cselekvésben, az céltalan avagy indifferens a célok sokaságával szemben". ${ }^{446}$ Emlékezzünk: Nietzsche már 1868-ban tagadta az organikus kanti, teleologikus értelmezésének létjogosultságát; ő maga célszerütlen organizmusban gondolkodik, melyben a feleslegnek mint a folyamatos megújulás örökös ismétlődése garanciájának, konstitutív funkciója van. ${ }^{447}$

Nem azt állítjuk, hogy a fentiekben felsorolt hivatkozásbeli „pontatlanságokért” Heideggert kellene hibáztatnunk, különösen, mivel a Förster-Gast kompiláció hiányosságaival maga is tisztában volt. Mindössze azt gyanítjuk, hogy mindez éppen, hogy hasznos lehet egy olyan interpretáció számára, mely az értelmezés konzekvenciáit a kezdetektől szem előtt tartja. Nietzsche elmélete a hatalom akarásáról teljes mértékben támogat is egy ilyen vállalkozást, két feltétel teljesülése esetén: amennyiben igazolhatóan a metafizikai gondolkodás betetőzésének tekinthető, és amennyiben előrevetíti az őt meghaladó gondolkodásmódot - a heideggeri filozófiát. De nem volna ez körben forgó érvelés?

\section{2. c. Deleuze és a „szelektív ontológia”}

$\mathrm{Az}$ ontológiai differencia gondolata meglehetősen inspiráló volt a Nietzscheértelmezők azon tábora számára, akik amellett tették le a voksukat, hogy Nietzschének igenis sikerült a metafizika meghaladása - előbb is, mint Heideggernek. Ez a meggyőződés adja meg a posztmodern differencia-filozófia alaphangját; melyen belül jelen munka keretei között Gilles Deleuze radikálisan „,immanens”, illetve Jacques Derrida legalább ennyire radikálisan „el-különböződő” különbség-fogalma lesz érdekes. ${ }^{448}$ Deleuze interpretációja számunkra

\footnotetext{
${ }^{446}$ ÚF 5[198], illetve 5[212] / KSA 10.304, illetve 10.308

${ }^{447}$ Vö. jelen írás 47. lábjegyzetével.

${ }^{448}$ Daniel W. Smith: „Deleuze and Derrida, Immanence and Transcendence: Two Directions in Recent French Thought." In: Between Deleuze and Derrida. Ed. Paul Patton, John Protevi. Continuum International Publishing, 2003, pp. 47-63. Smith Giorgio Agambenre hivatkozva a kortárs francia filozófia két „görbéjét” különbözteti meg: az immanencia tradícióját, amely a létező univocitásából indul ki, és amely Spinoza és Nietzsche nyomait követi, ide sorolja Deleuze-t és Foucault-t; valamint a transzcendenciáét, amely Kant és Husserl nyomán egyfajta negatív teológiát képvisel, ilyen például Lévinas és Derrida gondolkodása. Smith hozzáteszi: ezt a felosztást a maga részéről semmiképp sem oppozícióként; hanem a filozófiai ,pályák” irányának különbsége, illetve az egymáshoz való viszonyuk értelmében fogadja el. Ez persze nem változtat azon a számunkra problematikus momentumon, hogy Smith és Agamben Nietzschét éppen az általunk „mérsékeltnek” nevezett irányzatba sorolják. Számunkra szimpatikusabb Edith Wyschogrod „felosztása”, aki Deleuze-t a „plénum” erősen neoplatonista beállítottságú fillozófusának, míg Derridát ténylegesen differencia- gondolkodónak tartja. Ld. Edith Wyschogrod: Saints and Postmodernism: Revisioning Moral Philosophy. Chicago UP, Chicago-London, 1990, pp. 208-217., illetve 221., 229. Hasonló álláspontot képvisel John D. Caputo, aki úgy véli, a Deleuze-féle
} 
vitathatónak tünik. A differencia-filozófia álláspontjáról határozottan polemizál Heideggerrel, a „nihilizmus” mint a metafizikus gondolkodás immanens logikájának betetőzése tekintetében ugyanakkor erősen heideggeriánus „tüneteket” mutat. De éppen ez a Deleuze gondolkodásában fellelhető belső önellentmondás hívja fel a figyelmünket két olyan problémára, melyek jelen disszertáció voltaképpeni inspirációjául szolgáltak. Ezen a ponton merül fel ugyanis a kérdés, hogy miért is problematikus egy radikális különbség-filozófia számára Heidegger Nietzsche-kritikája, illetve, hogy Deleuze mely ponton és mi okból riad vissza a differencia-gondolkodás radikalizálásától. Úgy véljük, hogy a magyarázat mindkét esetben ugyanaz, nevezetesen, hogy az interpretátorok már eleve egy elözetes elvárással [ti. saját filozófiai koncepciójuk birtokában] érkeztek az értelmezési feladathoz. Deleuze esetében, azt gyanítjuk, ez az előzetes elvárás a differencia-filozófia szellemében értett Hegelkritika, amely a különbség affirmatív és immanens koncepciójában jut kifejezésre. Ennek megfelelően Deleuze az örök visszatérést az idő és az idő-dimenzió szintéziseként értelmezi, melyben a létet a visszatérés konstituálja; a müködés elve pedig a hatalom akarása, mely örökké újratermeli és a létbe hozza a különbséget.

Deleuze úgy véli, már a platonizmus is magában rejtette az anti-platonizmus lehetőségét, hiszen, bár alapvetően az ontológiai differencia felszámolását tűzte ki célul, nem rendelkezett semmilyen kategoriális rendszerrel, így a differencia voltaképpen fennmaradt, megőrizve a káosz-kozmosz immanens azonosságát. Azok a rendszerek, melyek nem számolnak magának az időnek a konstitutív erejével, nem tudnak mihez kezdeni a különbséggel sem. A „két világ” dualizmusát azután a karteziánus gondolkodás is megőrizte, Kant pedig tovább mélyítette, ugyanis a különbség magában az időben van, tehát nem „oldható fel” a transzcendenciában. Deleuze azt állítja, Kant nem veszi figyelembe a gondolkodás időbeli jellegét: az elgondolt létező már nem ugyanaz, mint az elgondolható; így tehát az elgondolt dolog elgondolhatósága nem jelenti, hogy a dolognak léteznie is kell. A kanti transzcendentalizmus Deleuze szerint túlságosan is „empirikus”, mert a különbséget csak annak külsőleges, megkülönböztető funkciója tekintetében veszi számításba, de azt is

Nietzsche túlságosan is szerethető, engedékeny, és túlságosan kevéssé „tragikus”; ellenben Derrida Nietzschéje képes a létező extrém „heterológiájának” igenlésére. (Ld. John D. Caputo: Against Ethics: Contributions to a Poetics of Obligation with Constant Reference to Deconstruction. Indiana UP, Bloomington, 1993, pp. 42-68.) 
csak azért, hogy azután a tudatos észlelet szintetikus egységében oldja fel. A különbség azonban elsődlegesen időbeli, azaz a transzcendenciában hat, de immanensen van. ${ }^{449}$

Deleuze Kant-kritikájának lényege, hogy az időbeliség figyelmen kívül hagyásával az ideák a transzcendentális szintézisben az értelem szisztematikus egységeiként egyszerre lennének transzcendens és immanens módon is elgondolva. Számára a különbség valódi filozófusai Nietzsche és Heidegger, amennyiben ők az „ismétlésben” felismerték az ontológiai mozzanatot, amely egyszerre hajtja végre az ideák megkülönböztetését és az „aktualizáció” értelmében a létbe hozó megkülönböztetést. A megértés mint szubjektum-objektum viszony csak a szubjektumban bekövetkezett „törés”, a tudatos és tudattalan így létrejövő különbsége révén lehetséges, melyben a tudat a tárgyra mint önmaga „másikára” tekinthet. A nietzschei hatalom akarása, vagyis az akarat önmagát-akarása tehát a „lehetőség” mint olyan igenlése. Deleuze szerint az örök visszatérés gondolatában a hatalom akarása a hasonlóság és az ismétlődés elveként tartja fenn a különbséget: a valóságos, tehát immanens létezés lehetőségét. $^{450}$

A „kettős affirmáció” tematizálásával ${ }^{451}$ Deleuze voltaképpen azt állítja, hogy az örök visszatérés gondolatában Nietzsche egyfajta „szelektív ontológiát” müködtet, melynek alapelve az akarás és teremtés azonossága. Az első affirmáció (maga az örök visszatérés gondolata) a változást (ti. a folyamatos keletkezést) affirmálja, amely azonban, teszi hozzá gyorsan, csak annyiban lét, amennyiben egy második affirmáció tárgya. A deleuze-i olvasat „kulcsfogalma” Dionüszosz, az átváltozás princípiuma; a dionüszoszi elem kristályosítja radikális igenléssé a tagadást mint olyat. Deleuze úgy véli, Zarathustra az örök visszatérés gondolatában Dionüszosz korának, az akarva értékelö és értékelve teremtő emberfeletti ember korának az eljövetelét jelenti be, úgy, hogy e bejelentésben ő maga még csak az elmúltak tagadásának fázisában van. Láthatjuk tehát: az, amit Deleuze ,az átváltozás örök élvezetének”, vagy „aktív destrukciónak”452 nevez, nem más, mint annak a folyamatnak a leírása, melynek során Heidegger az önmagát akaró akaratban előbb a nihilizmust, majd végül a metafizikát is beteljesítettként mutatja fel. A heideggeri-deleuze-i interpretáció alapján tehát az értékeket átértékelő genealógia voltaképpen a dialektikus gondolkodás antitézise. Deleuze,

\footnotetext{
${ }^{449}$ A transzcendentális szintézis időbeliségének deleuze-i kritikájáról lásd bővebben: Beth Lord: „Deleuze and Kant.” In: The Cambridge Companion to Deleuze. Ed. Daniel W. Smith, Henry Somers-Hall. Cambridge UP, New York, 2012, pp. 82-101.

${ }^{450}$ Gilles Deleuze: Difference and Repetition. Trans. Paul Patton. Columbia UP, New York, 1994, pp. 89-91., 116-118., 128-134., 165-167., 218-221., 258-260.

${ }^{451}$ Vö. Deleuze 265-295. o.

${ }^{452}$ Deleuze (1999) 269-270. o.
} 
mint említettük, kifejezetten hangsúlyozza értelmezésében a nietzschei filozófia ,antidialektikus" karakterét, melynek révén az örök visszatérés gondolata alkalmassá válik a „különbség” fogalmának átfogó rehabilitációjára. Hegel ugyanis azzal, hogy a különbséget pusztán feloldandó ellentmondásként vette fel rendszerébe, megfosztotta azt aktív - vagyis a deleuze-i értelemben „teremtő” potenciáljától. Így tehát azzal, hogy Deleuze a hatalom akarásában a különbség különbözni akarását affirmálja, a heideggeri értelemben lét- és értékteremtőként ismeri fel. Ennek kapcsán máris felvetődhet egy lehetséges ellenvetés. Annak ellenére, hogy Deleuze célja az ellentmondás, a negativitás kiküszöbölése a „különbség” fogalmából, az „aktív” és „reaktív” erők oppozíciójában mégis megőrzi azt. Nem abban az értelemben, amennyiben itt voltaképpen az aktív és passzív hagyományos oppozíciójának újragondolásáról van szó; hanem sokkal inkább azért, mert az ellentmondást Deleuze éppen az ,aktivitás” mozzanatán belül tartja fenn, amikor az erő aktivitását a fentiek szerint értett „teremtésként” definiálja. Deleuze a következőket állítja:

[...] a változás és a lét egy és ugyanaz az affirmáció, amely csupán átmegy egyik hatalomból a másikba, mint egy második affirmáció tárgya. [...] A hatalom akarása mint differenciális elem hozza létre és fejleszti ki a különbséget az affirmációban, tükrözi vissza a különbséget az affirmáció affirmációjában, és hozza vissza azt az affirmált affirmációban. [...] Az örök visszatérés azt jelenti, hogy a lét kiválasztás. Csak az tér vissza, aki igent mond vagy amire igent mondanak. ${ }^{453}$

Megállapíthatjuk tehát: Deleuze érvmenete alapvetően Heideggerével párhuzamosan halad, hiszen, bár különbség-filozófiaként szándékozik felmutatni a nietzschei gondolkodást, mégis azzal, hogy az örök visszatérés gondolatát a hatalom akarásának a fentiekben ismertetett, önnön kiteljesedésében megvalósuló, radikálisan immanens koncepciójába zárja, egyfajta,,szelektív ontológiaként” értelmezve azt, a különbséget magát éppen, hogy deaktivizálja.

Deleuze saját filozófiája kapcsán Nietzschére és Spinozára hivatkozik, mint előfutáraira, Nietzsche és Deleuze „közös nevezője” tehát Spinoza, közelebbről az affektustan lehet. ${ }^{454}$ Amint azt korábban, a még csak jelzés-értékkel bíró harmadik exkurzusban

\footnotetext{
${ }^{453}$ Deleuze (1999) 289-290. o.

${ }^{454}$ Mint a harmadik exkurzusban említettük, a gondolati rokonság Nietzsche szerint öt lényegi tagadásban manifesztálódik nevezetesen az akaratszabadság, a teleológia, az erkölcsi világrend, az önzetlenség, és a „gonosz” tagadása.(Vö. BVN-1881, 135. „An Franz Overbeck.”)
} 
említettük, a spinozai gondolkodás legáltalánosabb tanulsága Nietzsche számára a módusz szükségszerü létezésének a potentia-potestas egységként, azaz hatásában kiteljesedőként értett hatóképesség [activitas] koncepciójával történő alátámasztása - ugyanez a deleuze-i aktivitásfogalom magva is. „A szabad, kreatív aktivitás [...], ami magát önmagában, függetlenül és szükségszerüen tételezi: a legszubjektívebb egyben a legobjektívabb is." ${ }^{455}$ Ahogy az említett rádió-interjúban is elhangzott: az élvezet mindig ön-élvezet, mindig a hatalomgyakorlás élvezete, a hatóképesség élvezete, az erő élvezete - az aktivitás és az élvezet elemi összetartozása pedig mindkettő eredendő immanenciáját előfeltételezi. Azonban az immanencia élvezete, valljuk be, igencsak korlátolt élvezetnek tünik. Mi éppen ezért elfogadhatóbbnak tartunk egy olyan magyarázatot, amely szerint annak, hogy Nietzsche „előfutáraként” hivatkozott Spinozára, tényleges oka éppen hogy az affektus-tanban rejlő forradalmi lehetőségek megsejtése volt. Egészen pontosan annak felismerése, hogy az önmagát akaró hatóképesség Spinoza által körvonalazott gondolata épp azáltal válhat a legfélelmetesebbé, ha beteljesülését a beteljesülésről való alapvető lemondásban találja meg. A fenti gyanú okán jutottunk arra a következtetésre, hogy Nietzsche „beismerése” indokolttá teszi két jóval korábbi, Nietzsche által nem hangsúlyozott, de futólag szintén „bevallott” hatástörténeti összefüggés jelentőségének újragondolását. Ezen állításunk megalapozása okán azonban még ismét vissza kell kanyarodnunk a kanti sematizmus problémájához, amely (természetesen az egy Spinoza kivételével), az összes általunk érintett gondolkodó számára viszonyítási pontként szolgált. Úgy gondoljuk, hogy mivel a transzcendentális sematizmus a reprezentáció-kritika első artikulált megjelenése a metafizikai tradíción belül, így a hozzá való viszony az, ami egyértelmüen pozicionálja nem csak Nietzsche metafizika-kritikáját, hanem a heideggeri Nietzsche-kritikát és a posztmodern különbség-filozófia két, általunk tárgyalt képviselőjét is.

\section{2. d. A ,Kant-probléma"}

A kanti kriticizmus elsődleges intencióját tekintve a felvilágosodás racionalizmusának kritikája, és mint ilyen, alapvetően a szubsztancializmusé. Kant úgy véli, Descartes, Leibniz és Spinoza túl messzire merészkedtek, mikor a gondolkodás és a lét szerkezete között analógiát, sőt, tökéletes megfelelést tételeztek; ezzel ugyanis jelentősen túlbecsülték az

\footnotetext{
${ }^{455}$ Gilles Deleuze - Felix Guattari: „Mi a filozófia?” Ford. Pörczi Zsuzsanna, Takács Ádám. In: Nappali Ház,
} 1993/4. 65. o. 
emberi megismerőképesség hatókörét. Mint láttuk, az általunk tárgyalt gondolkodók mindegyike számára, eltérő aspektusból ugyan, de a transzcendentális sematizmus bír kitüntetett jelentőséggel a kanti gondolkodás egészén belül. Vegyük tehát sorra röviden ezeket a relációkat.

$\mathrm{Az}$ értekezés első részének első két fejezetében igyekeztünk a megfelelő hangsúlyt fektetni Nietzsche Kant-kritikájának bemutatására. Kunszt György ennek kapcsán Nietzschének a felvilágosodás kiteljesítése, az „új felvilágosodás” iránti igényére hívja fel a figyelmet; arra tudniillik, hogy Nietzschét a felvilágosodásban elsősorban annak öntelt semmitmondása, fellengzős korlátoltsága irritálta. A túlzottan „forradalmi”, túlzottan „színpadias” jelleg az, amelyek mögött már szinte ködbe vész a felvilágosodásnak a gondolkodás megtisztítására irányuló eredeti törekvése. Úgy vélte, a francia felvilágosodásnak ez az alapjellege, németes komolysággal és pedantériával leplezve, de a német idealizmusban is megjelent. ${ }^{456}$ Nietzsche számára Kant Schopenhauer kapcsán lett érdekes - utóbb pedig gyanús. Mikor 1865-ben megismerkedik Schopenhauer filozófiájával, a müvész-metafizika óriási hatást gyakorol az akkor még filológus-hallgató, alig huszonéves Nietzschére. Schopenhauer és az akarat filozófiája eleinte a kanti Ding an Sich kritikája révén lesz szimpatikus a számára, ekkortájt olvassa ugyanis Friedrich Albert Lange A materializmus története címü müvét, melynek konzekvenciáját a következőkben látja: mivel az ember számára minden képzetként adódik, még a saját teste is, ezért abszurd vállalkozás lenne a dolgok „magánvaló lényegét” feltételezni. ADing an Sich nem csupán megismerhetetlen, de még csak abban sem lehetünk biztosak, hogy saját tapasztalatunktól függetlenül rendelkezik-e egyáltalán bármiféle jelentéssel. Nietzsche ekkor még úgy véli, hogy Schopenhauer gondolkodása kiállná még a Lange-féle materializmus próbáját is. Pár évvel később azonban már felismeri, hogy Schopenhauer az akarat predikátumait az ,akarat világa” és a „reprezentáció világa” közti ellentmondásból vezeti le, fenntartva ezzel a kanti értelemben vett „,két világot”, mindössze annyi változott, hogy a Ding an Sich pozícióját a „,magánvaló

\footnotetext{
${ }^{456}$ Vö. Kunszt György: Nihil és ámen. (Nietzsche-reflexiók.) Gond - Palatinus, Bp., 2002, 50. o. Az „új felvilágosodás" kapcsán lásd továbbá: Aldo Venturelli: Kunst, Wissenschaft und Geschichte bei Nietzsche. De Gruyter, Berlin, 2003. s. 136-154. Venturelli Nietzschének az ún. „szabadgondolkodókkal” [libres penseurs] szembeni ellenszenvét emeli ki, akik nem jutottak el odáig, hogy magát az értékek értékét kérdőjelezzék meg. Nietzsche tervezett, ,új felvilágosodásában” minden állandó változásban van, hasonlóan ahhoz a mozgáshoz, melyet a reneszánsz kor tudósai és gondolkodói indítottak el, és amelynek tehát a francia felvilágosodás is csak gyenge utánzata, a német romantika és idealizmus pedig a leghatározottabb ellentettje. A reneszánsz és a felvilágosodás alapvetően olyan „ellenmozgások” a történelem során, melyek a Szókratésszel meginduló intellektuális „erózió” ellenében hatnak, és melyek a filozófiai gondolkodásnak a preszókratikus filozófiában predesztinált magasabb lehetőségeit vetítik előre. Nietzsche gondolkodása azonban e tekintetben nem pusztán a felvilágosodást, hanem a görögöket is meg kívánja haladni.
} 
akarat" vette át. Azt azonban már Lange Kant-kritikája kapcsán elismerte Nietzsche, hogy a magánvaló dolog és annak képe között nincs szó ellentmondásról, lévén a Ding an Sich maga is pusztán a mi képzetünk. Ha ugyanis a magánvaló, vak akarat az, ami folytonosan reprezentálni kívánja önmagát, így hozva létre a képzetek világát, akkor a principium individuationis, az individuáció elve korábbi lenne, mint maga az intellektus. Az intellektus így vagy már eleve összetartozik a magánvaló akarattal, vagy pedig nem is létezhetne; mivel azonban kétségtelenül létezik, nem lehet a reprezentáció eszköze, hanem csak magánvaló dolog, tehát akarat. ${ }^{457}$ A schopenhaueri akarat-filozófiát illető kételyek felmerülésével egy időben Nietzsche ugyanezt a problémát véli felfedezni a kanti teleológia kapcsán. Úgy véli, a természeti célszerüség feltételezése annak az indokolatlan optimizmusnak a terméke, melynek felszámolására először a felvilágosodás vállalkozott - sikertelenül, és amelyről maga Kant sem tudott lemondani. Nietzsche tehát már ekkor felismerte, hogy a kanti kriticizmus (és az arra épülő schopenhaueri akarat-metafizika) megtorpant azon a ponton, ahol valóban veszélyessé vált volna a terep, ahol tudniillik a kriticizmus a metafizikus gondolkodásmód átfogó kritikájává válhatott volna. ${ }^{458}$

\footnotetext{
${ }^{457}$ Vö. BAW III.452-453. „Zu Schopenhauer.”

${ }^{458}$ Arról, hogy a kritika ilyen, általános érvényủ kiterjesztése milyen következményekkel jár még magára a nietzschei történelem-felfogásra nézve is, lásd: Andreas Urs Sommer: „Sieben Thesen zur Geschichtsphilosophie bei Kant und Nietzsche." In: Kant und Nietzsche im Wiederstreit. Hg. Beatrix Himmelmann. De Gruyter, Berlin, 2005, s. 217-242. Sommer hét pontba szedve vázolja a kanti és nietzschei történelemfilozófia egymáshoz viszonyított pozícióját: 1. Az örök visszatérésről szóló tanítás a történelemfilozófia hagyományos haladáselméleteinek lehető legélesebb ellentéte, mely azonban sokat köszönhet a kanti előzményeknek. Kant szerint a történelemfilozófia vigasztaló, a világgal megbékítő alternatívákkal kell, hogy szolgáljon. Nietzsche ellenben úgy véli, a haladás ilyen elmélete már eleve dekadens, mert minden ízében közönséges: általános érvényü követelményeket (ti. a ,jobb”, „teljesebb”, „tökéletesebb” irányába történő haladás) támaszt, és alanyát is általánosítja, amennyiben a fent leírt „fejlődés” tekintetében az „emberiség”, nem pedig az individuum érdekeit, igényeit veszi figyelembe. 2.Mind a haladáselmélet, mind pedig a visszatérés-tan a történeti esetlegesség filozófiai relevanciájának a 18. század óta egyre sürgetőbbé váló kérdésére adott válasznak tekinthető. A felvilágosodás korában a történelemfilozófiának kettős funkciója volt: egyrészt az emberformálta, történeti múlt, jelen és jövő funkcionalitásának bizonyítása (hasonlóan a természettudományokhoz, melyek a természet tekintetében teszik ugyanezt), azaz a partikuláris, emberi esetlegesség eliminálása; másrészt, ezen túlmenően, az abszolút kontingencia problémájának megoldását kereste. Mondanunk sem kell, ettől mennyiben eltérő a nietzschei „Experimentalphilosophie” teljes koncepciója. 3. Egy, a spekulatív-univerzalisztikus történelemfilozófia és a kritikai genealógia közti fontos különbség azonban nem merül fel a fentiek dogmatikus avagy kísérleti karakterének problémája mentén: a történelemfilozófia eredendően sem nem dogmatikus tudomány, sem pedig kísérleti gondolatmenet, míg a genealógia éppenséggel ön-dogmatizáló tendenciákat mutat. A 18. század közepének történelemfilozófiája, mutat rá Sommer, éppen saját kísérleti fázisában volt, hiszen egészen Kantig ,a” történelemfilozófia csak egy ábránd lehetett, koherens rendszer-elmélet azonban nem létezett. Kanttal véget ért a kísérletezés, és a gondolkodásban beköszöntött a dogmatizmus uralma. 4. Ugyanakkor azonban a nietzschei genealógia és a kanti történelemfilozófia egyaránt túl közel merészkednek a fikció határaihoz, mondja Sommer. Kant a történeti ész kritikájakormind stílusát, mind pedig mondandóját tekintve is túlzottan romantikus, mikor a történelmet, erkölcsi-motivációs funkciója tekintetében Isten képzetéhez hasonlítja; Nietzsche pedig, a Zarathustrától kezdve hasonlóan túlságosan irodalmi és alig-alig „tudományos”. 5. A történelemfilozófia a német idealizmusban (Hegel) és a poszt-idealisztikus materializmusban (Marx) dogmatikus átalakuláson ment keresztül, Nietzschével azonban visszatért a kísérleti filozófia állapotába. Bár Nietzsche maga a „történelemfilozófia” kifejezést egyáltalán nem, a „történelem
} 
Mindezeket figyelembe véve más megvilágításban áll előttünk a Spinoza-hatás korábban említett problémája is. Ha egyetértenénk Deleuze heideggeriánus interpretációjával, azt kellene állítanunk, hogy a hatalom akarásában az önmaga maximumát elérni képes akarat olyan módon viszonyul önmagához, ahogyan az ontológiai értelemben kitüntetett Lét viszonyul a „létező egészéhez”; tudniillik felvázolja számára a „transzcendencia horizontját”. Deleuze helyesen látja a nietzschei Kant-kritika episztemológiai jelentőségét az igazság „veridikus” koncepciójának bírálata kapcsán, ${ }^{459}$ épp ezért olyan meglepő számunkra, hogy nem veszi figyelembe a módszertani kockázatot, melyet az ontológiai differencia heideggeri koncepciójának átvételekor a transzcendentális sematizmus Heidegger-féle alkalmazása hoz magával. Ugyanakkor kérdéses, Deleuze saját pozíciója mennyiben lenne tartható a heideggeri alapok híján...

Heidegger fundamentálontológiáját, mint a par excellence metafizikai alapvetést nagymértékben a kanti sematizmustanra alapozza, melyet ő maga a teljes kanti rendszer lényegi momentumaként, az egészében vett kanti metafizika szintézisét, objektív egységét megteremtő alapgondolatként értelmez. Eszerint a kanti transzcendentális sematizmus ontológia, mely az a priori szintetikus ítélet lehetőségének megteremtésével egyúttal a Dasein egzisztenciájának lehetőségét is megteremti, lévén mindkét folyamat időben konstituált. Idézzük fel tehát röviden a transzcendencia és az ontológia analógiájának heideggeri gondolatát. A kanti metafizika alapjait a transzcendentális sematizmus fekteti le, ahol az általában vett tapasztalat lehetőségfeltételei ugyanazok, mint a tapasztalat tárgyainak időbeli feltételei. Heidegger szerint a tapasztalat érzékelésünk véges, passzív, intuitív tudása a Ding an Sich-ről, a „lehetőség” pedig kétértelmü. A lehetőség annak körét jelöli ki, mit tapasztalhatunk egyáltalán; éppen ezért állíthatja Heidegger, hogy a lehetőség/lehetségesség problémája egybeesik a szintetikus a priori ítéletek problémájával. A lehetőséget a tudás $a$ priori formái definiálják, melyek így egyszerre megengednek és korlátoznak; a tapasztalás lehetősége a transzcendencia lehetősége az ember számára. A tapasztalat lehetőségfeltételei tehát a következők: először is képesnek kell lennünk az előzetes tájékozódásra az adott dolog kapcsán: az érzékelésre és fogalmi megragadásra való képességünk révén adódhat egyáltalán

filozófiája” terminust pedig csak elvétve használja, egyértelmü, hogy magát a „világfolyamatban” történő gondolkodást tartja elfogadhatatlannak - már a második Korszerütlenben is a radikális kritika eszközeként tekint a történelemre. 6. Ezen visszarendeződés révén Nietzsche lemondott ugyan a spekulatív-univerzalisztikus történelemfilozófia vigasztaló, teleologikus, tökéletesen bizonyos válaszairól; a történeti kontingencia relevanciájának megkérdőjelezéséröl viszont semmiképpen. 7. Ez utóbbi kérdéstől ugyanis többé már nem szabadulhatunk; még Nietzsche forradalmi történelemfilozófiája sem kerülheti el, hogy saját sematizmusainak, saját válaszainak engedelmeskednie kelljen.

${ }^{459}$ Ld. Deleuze (1999) 145-154. o. 
a tárgy megismerhetőként a számunkra. Emellett a tárgynak a mi hozzá való viszonyulásunk módján kell számunkra adódnia, tehát a létező tulajdonságaival kell rendelkeznie ahhoz, hogy tapasztalásunk idejében létezhessen. Heidegger szerint a transzcendenciára való képesség teszi lehetővé, hogy a pillanatnyi benyomások észleletekké formálódjanak (apprehenzió), azok sematikus kategóriák szerint rendeződjenek (reprodukció), végül pedig létrejöhessen a voltaképpeni megértés (rekogníció). Az appercepció szintetikus egysége Heideggernél temporalitása tekintetében analóg a Dasein egzisztenciális konstrukciójának egységével, a megismerés tehát már mindig is ontológia. Az ontológiai ismeret tárgya azonban mindig a „valami”, az „X”, tehát a „Semmi”; a reprezentációnak ellenben tárgyra van szüksége; azonban, mint fentebb láttuk, Heideggernél a Semmi esszenciálisan a Léthez mint olyanhoz tartozik. Így tehát a heideggeri interpretációban a transzcendentális tárgyban az emberi tapasztalat általános temporalitása egyszerre fejezi ki az emberi végességet, és az ember által megismerhető dolgok véges létezését. A temporalitás pedig, a tulajdonképpeniség vonatkozásában, semmi. Az időnek ez a láthatatlan, ám mégis mindenütt-jelenvaló „horizontja” jelöli ki az emberi megértés és létezés véges kereteit. ${ }^{460}$

Heidegger talán leghíresebb vitapartnere, Ernst Cassirer homlokegyenest eltérő álláspontot képvisel. Cassirer szerint a Kant-értelmezések két alapvető pozíciót vesznek fel: a pozitivista „kriticizmusét”, mely a kanti észkritikát ismeretelméletként értelmezi, illetve Heideggerét, aki szerint A tiszta ész kritikája metafizikai alapvetés, közelebbröl: fundamentálontológia. ${ }^{461}$ Cassirer szerint Heidegger „méltánytalanul” ítélt a „neokantiánus” tradícióról, sőt, mi több, nem is értette azt helyesen. Az ő értelmezésében Kant filozófiája kifejezetten nem kíván ontológia lenni, hiszen a metafizikai hagyománynak éppen azzal a tendenciájával akar leszámolni, mely a lét általánosságát veszi alapul, hogy aztán ebből mint tételezett Egészből kiindulva alkossa meg saját világnézetét. Cassirer szerint ugyanis Heidegger értelmezése épp a „kopernikuszi fordulat” lényegét, tudniillik a filozófiának a tudás objektivitásától annak szubjektivitása felé történő elfordulását nem veszi figyelembe. Az alapvető hiba ugyanis épp abban a hagyományosan elfogadott előfeltevésben van, hogy az objektivitás objektivitását, vagyis szükségszerüségét és általánosságát, a „létből” való részesedés garantálja. Kant az észkritikával azt kívánta bizonyítani, hogy a dolgok számunkra nem objektív módon vannakadva, hanem érzékelésünk és értelmünk médiumán keresztül,

\footnotetext{
${ }^{460}$ Vö. Charles M. Sherover: Heidegger, Kant and Time. Indiana UP, Bloomington - London, 1971, pp. 120130.

${ }^{461}$ Vö. Heidegger (2000) 21. o.
} 
„szubjektíve” adódnak. Cassirer itt Kant híres, 1772. február 21-i, Marcus Herzhez írott levelére hivatkozik, melyből legyen szabad szintén idéznünk:

A tiszta értelmi fogalmakat tehát nem az érzéki észleletekböl kell absztrahálni, $\mathrm{s}$ nem is a képzetek fogékonyságát fejezik ki az érzékek útján, hanem forrásuk ugyan a lélek természetében van, de nem az objektum alkotja őket, s nem is ők hozzák létre az objektumot. [...] Azt mondottam, az érzéki képzetek úgy ábrázolják a dolgokat, ahogyan megjelennek, az intellektuálisak úgy, ahogy vannak. Ám hogyan adódnak számunkra e dolgok, ha nem ama módon, ahogy bennünket afficiálnak, s ha az ilyen intellektuális képzetek belső tevékenységünkön alapulnak: honnét származik a képzetek összhangja a tárgyakkal, melyeket nem a tevékenység hoz létre $[\ldots] ?^{462}$

Cassirer leszögezi: maga a „transzcendentális” sem jelent mást Kantnál, mint azt a tudást, hogy megismerésünk csak a priori módon vonatkozhat a tapasztalat tárgyaira „transzcendentális” alatt pedig az a priori lehetséges szubjektív megismerést értjük. A filozófia „kopernikuszi fordulata” után a „metafizika”, mely tehát a fenti értelemben „transzcendentális”, többé már nem keresheti megalapozását az ontológia objektivitásában. ${ }^{463}$ Heidegger, mint láttuk, az ontológia fenomenológiai koncepciójában a Létet mint a létezőben fenoménként önmagán megmutatkozót és a logosz által megmutatkozni-hagyottat vizsgálja. Azonban ezen a ponton mintha megfeledkezne a transzcendencia legalapvetőbb mozgásáról, melynek révén az ész képessé válik meghaladni a puszta „dologi”, az „érzéki” kauzális szféráját. „Az értelem »végesnek« mondható, amennyiben sohasem ragadja meg az abszolút tárgyakat, még kevésbé hozza őket létre önmagából; ám »végtelen«, amennyiben »a föltételek szintézisének abszolút totalitása« tulajdonképpeni és lényegi föladatát alkotja." ${ }^{464}$ Amikor tehát Heidegger a transzcendentális

\footnotetext{
${ }^{462}$ Kant levele Marcus Herznek 1772. február 21-én. Ld. Immanuel Kant: „A fordulat levele.” Ford. Vidrányi Katalin. In: Világosság, 2004/6. 7-10. o.

${ }^{463}$ Vö. Ernst Cassirer: Kant élete és müvei. Ford. Mesterházi Miklós. Osiris, Bp., 2001, 153-170. o.

${ }^{464}$ Ernst Cassirer: „Kant és a metafizika problémája. Megjegyzések Martin Heidegger Kant-interpretációjához.” Ford. XY In: Martin Heidegger: Kant és a metafizika problémája. Ford. Ábrahám Zoltán, Menyes Csaba. Osiris - Gond, Bp., 2000, 379. o. Heidegger Kant-interpretációja kapcsán Cassirer alapvetően azt kifogásolja, hogy az a végességet emeli ki mint az emberlét és az emberi megismerés alapkarakterét, és arra mint fundamentálontológiai „tényre” fókuszál az észkritika értelmezésekor, minden egyéb vonatkozásban erre a fókuszpontra utalva vissza. Heideggernél túl nagy a hangsúly a „szemlélet puszta receptivitásán”, a „diszkurzív gondolkodás” általánosságán, mondja Cassirer, miközben a kanti intenciók egyértelmüvé teszik az „értelem spontaneitásának” kitüntetettségét. A létező heideggeri „egységének” megteremtésének feladatát Kantnál logikusan a transzcendentális esztétika és a transzcendentális logika értelmi egységét megteremtő transzcendentális sematizmus végzi el, mely ily módon a végesség egységébe zárja az emberi megismerést. Cassirer azonban, amellett, hogy elismeri a sematizmus-elmélet kiemelkedő jelentőségét Kantnál, felhívja a figyelmet a kanti szándék alapvető, az „érzéki” és az „érzékfeletti” megkülönböztetéséből fakadó kettősségére,
} 
képzelőerőt mint a megismerést a végességbe szintetizáló fakultást veszi figyelembe, akkor a „létező egészét” a végességként értett időbeliségbe zárja; ezzel pedig, Cassirer szerint, teljes mértékben figyelmen kívül hagyja a kanti gondolkodás eredendően dualisztikus jellegét. „Heideggernek jogában állt fundamentálontológiai álláspontjáról vitatni ezt a dualizmust, de nem kellett volna tagadnia és letagadnia. ${ }^{, 465}$ Mutatis mutandis, Cassirer azt veti Heidegger szemére, hogy, köznapi kifejezéssel élve, mintegy átesett a ló túloldalára a ,jobban értés” tekintetében. Heidegger szerint Kant filozófiája lényegében ontológia, ennek igazolása céljából állítja a sematizmus-fejezetet mindA tiszta ész kritikája, mind a teljes kanti rendszer középpontjába. Ez azonban, mondja Cassirer, nem pusztán öncélú, hanem konkrétan téves olvasat, hiszen a transzcendentális sematizmus nem magával az emberi létezéssel, pusztán az emberi tapasztalás lehetőségével és feltételeivel foglalkozik: nem a létezés, hanem a tapasztalás fenomenológiáját írja le. ${ }^{466}$

Úgy véljük, Heidegger Nietzsche-, illetve Kant-interpretációjának közös eredete a metafizika fundamentálontológiaként történő megalapozásának igénye. „Ugyanannak az örök visszatérése" Heidegger szerint annak kimondása, hogyan van a létező mint olyan összetétele tekintetében, a „hatalom akarása” pedig annak, hogyan van a létező egészként ebben az összetettségben. Az örök visszatérésben a létező egészként van, mely utóbbi a Lét alapvető

mely a végesség analitikáját is árnyalja. Heidegger értelmezésében ugyanis az emberi értelem végessége abban a korlátoltságban gyökerezik, mely tárgyait csak befogadni képes, de megteremteni nem. A Dasein a világot mint a Lét elé vetülő képeit érzékeli, és ez a viszony jelöli ki az emberi végesség legkonkrétabb határát. Kant azonban nem foglalkozik azzal, hogyan vannak a tárgyak önmagukban, kizárólag azzal, milyen módon és milyen mértékben képes az ember megismerni azokat. Azt tehát mégsem állíthatjuk, mondja Cassirer, hogy az ész semmilyen értelemben nem képes teremteni: az értelem teremtő ereje éppen annak spontaneitásában rejlik, ahogyan a maga számára elóállítja a dolgokat - a lét mint olyan teremtése Isten kiváltsága. Az ész kvázi „megparancsolja” az értelemnek a transzcendenciát, a kötöttségeken és meghatározottságokon való felülemelkedést - és éppen ezért nem lehet a korlátoltság értelmében időbeli. Az érzéki és az intelligibilis két világ, melyek közül az egyikben minden korlátolt, a másikban minden korlátlan: időtlen, sőt, idő-fölötti.

${ }^{465}$ Cassirer (2000) 386. o.

466 Heidegger egy szóval sem említi - állítja Cassirer -, hogy a sematizmus-tan voltaképpeni kifejtése a szintetikus alaptételekről szóló szakaszban történik, ahol is a sémák dedukciójának lehetősége kizárólag az a priori időmeghatározások révén adódik. Így tehát az idő a priori lehetőségfeltétele annak, hogy a tárgyak számunkra egyáltalán tárgyként adódhassanak, és mint ilyen, a kanti ismeretelmélet konstitutív eleme. Olybá tünik, mintha Heidegger azért emelte volna ki a sematizmus-fejezetet, és benne az időbeliségnek Kant által hiányosan kifejtett koncepcióját, mert számára ez jelentette Kant rendszerének lényegi elemét. Cassirer szerint a transzcendentális sematizmus éppen az érzéki meghaladásának lehetőségét, az érzékiből az érzékfelettibe való felemelkedés lehetőségét hivatott kifejezni; és hogy ez mennyire igaz, azt éppen a kategorikus imperatívusz fogalma és a kanti etika egésze teszi nyilvánvalóvá. A sematizmus törvényadás, de nem az érzéki, hanem az érzékfeletti világban; a feltétlen morális törvény feltétlensége éppen annak az érzékitől való függetlenségét jelenti. Cassirer konklúziója: Kantnál az érzéki és az érzékfeletti tökéletes összhangba kerülhet a véges emberi lényben - neki tehát, Heideggertől eltérően nincs miért „,szorongania”. (Vö. Cassirer [2000] 362-400. o.) Emellett ismét hivatkozhatunk Kant Herzhez írott levelére: „... elterveztem egy művet, mely körülbelül a következő címet viselhetné: Az érzékiség és az ész határai. Úgy gondoltam, ez két részből állna, egy elméletiből és egy gyakorlatiból. Az első két szakaszt tartalmaz. 1. A fenomenológia általában. 2. A metafizika, ám csupán természetes módszere szerint. A második rész ugyancsak két szakaszban. 1. Az érzés, ízlés és az érzéki kívánság általános elvei. 2. Az erkölcsiség alapjai.” (Ld. Kant [2004] 7. o.) 
karaktere, és amely a hatalom akarás révén lép az örök visszatérésbe, mely önmagában a folyamatos keletkezés ördögi körét futná. „Ugyanannak az örök visszatérése” mint folyamatos keletkezés [Werden] tehát a „hatalom akarása” révén tér vissza mindig ugyanakként, ti. Létként [Sein]. ${ }^{467}$ Heidegger konklúziója: „ugyanannak az örök visszatérése” képezi annak előfeltételét, hogy és ahogyan a sokaság és értelemnélküliség világa mégis a létező egységeként van - ahogyan a véges, mégis megértett létezés általában vett lehetőségét Kant alapozta meg. Ismételten le kívánjuk azonban szögezni, hogy semmiképpen nem azt állítjuk, hogy Heidegger egyik vagy másik esetben tévedett volna. Ellenkezőleg, azt feltételezzük, hogy értelmezéseiben pusztán azzal a szabadsággal élt, melyet a ,jobban értésnek” a „faktikus jelenvalólét” számára a hermeneutikai folyamat lezárhatatlansága révén adódó lehetőségével ő maga szavatolt a mindenkori interpretátor számára.

Ismét jeleznünk kell, hogy a „hatalom akarása” mint koncepció körüli bizonytalanságot nagyban elősegítette maga $A$ hatalom akarása címen kiadott kompiláció, melyet Elisabeth Förster-Nietzsche és Peter Gast igencsak megkérdőjelezhető szempontok alapján állított össze. A kritikai összkiadás egyik szerkesztője, Mazzino Montinari korábban már említett tanulmányában „emlékezett meg” elődei munkájáról, az általa jelzett eltérések közül most két olyat emelünk ki, melyek témánk szempontjából különösen problematikusnak tünnek. Annál is inkább így kell tennünk, mert maga Montinari, aki „fércmünek”, „tákolmánynak”468 tartja a kompilációt, külön felhívja a figyelmet arra, hogy az ,igazi” és „látszólagos” világ megkülönböztetése és az azzal kapcsolatos problémák ,a »Hatalom akarásá«-hoz készült ezt követő feljegyzések egyik fő motívumává válnak. Egy igazi, a látszólagossal szembenálló világba vetett hit Nietzsche szerint a jelenségeknek azt a komplexumát feltételezi, amit eleinte pesszimizmus, később nihilizmus, ettől kezdve pedig a dècadence névvel is illet." ${ }^{469}$ Ennek tudatában még inkább érthetetlen, vajon Förster és Gast milyen alapon dönthettek úgy, hogy a következő töredéket nem közlik a kompilációban:

[a »jelenségek« kifejezés ellen. NB.] Látszat, ahogy én értem, a dolgok igazi és egyetlen valósága - az, amelyhez az összes meglévő predikátum csak hozzájárul, és amit viszonylag legjobban még minden, tehát az ellentétes predikátumokkal is jelölhetünk. A szóval azonban nem fejezünk ki többet, mint annak nem kielégitö

\footnotetext{
${ }^{467}$ Hasonló álláspontot képvisel Josef Simon, aki szerint „Heidegger Nietzsche filozófiáját a metafizika eredetére és végére vonatkozó kérdéssel kapcsolta össze.” Vö. Josef Simon: „Welt auf Zeit. Nietzsches Denken in der Spannung zwischen der Absolutheit des Individuums und dem kategorialem Schema der Metaphysik." In: Krisis der Metaphysik. Ed. Günter Abel, Jörg Salaquarda. De Gruyter, New York - Berlin, 1989, s. 109-133.

${ }^{468}$ Montinari (1986) 101., illetve 103. o.

${ }^{469}$ U. ott 105 . o.
} 
mivoltát a logikai procedúrák és különbségtételek számára: az tehát »látszat« a »logikai igazság«-hoz viszonyítva - ami azonban maga is csak egy elképzelt világban lehetséges. Nem »látszat«-ot tételezek tehát a »valóság« ellenében, hanem megfordítva, a látszatot annak a valóságnak veszem, ami szembeszegül annak, hogy »igazságvilág«-gá változtassák. E valóság egy meghatározott neve »a hatalom akarása« lenne, nevezetesen belülről, nem pedig megfoghatatlan, cseppfolyós, Próteusz-természete alapján jelölve. ${ }^{470}$

Nietzsche A hatalom akarásának elökészítése idején visszatér ismeretelméleti kiindulópontjához, melynek körvonalait $A$ nem-morálisan fölfogott igazságról és hazugságról szóló írásban vázolta fel. Nem a „látszat” és a „valóság” áll tehát szemben egymással, hanem a „valóság” és az „igazság” - a valódi világ számunkra az, ami megjelenik; látszatról csak a logika beszélhet, amelynek szüksége van az ,igazság” fogalmára. A világ, amely a mi valóságunk az, ami természete szerint „,a hatalom akarása - „és semmi egyéb”. ${ }^{471}$ Nietzsche mellesleg nem sokkal korábban Afrikan Spirt idézi: „a tudat maga az, ami közvetlenül bizonyos: a gondolkodás létezését nem lehet tagadni, de még kétségbe vonni sem, mert ez a tagadás vagy ez a kétely ugyancsak a gondolkodás vagy a tudatosság állapotai, melynek megléte már önmagában is bizonyítja, hogy amit amazok tagadnak, az minden »értelem« velejárója." $" 472$

\section{2. e. Neokantianizmus, atom-elmélet és falszifikacionizmus}

Michael Steven Green egy, az örök visszatérés gondolatának jelentőségét vizsgáló tanulmányában a nietzschei filozófiát a neokantiánus sematizmus-kritika talaján álló falszifikacionista gondolkodásként aposztrofálja. ${ }^{473}$ Mint korábban, a második exkurzusban már említettük, Afrikan Spir sematizmus-kritikája értelmében az empirikus ítélet kanti elmélete inkoherens, ugyanis a tárgy és a róla alkotott képünk közti kapcsolat természetével nem képes kielégítően elszámolni. A „fundamentális antinómia” ugyanis, mint azt korábban már tárgyaltuk, Spirnél nem más, mint a lét és a keletkezés világa közötti különbségtétel.

\footnotetext{
${ }^{470}$ KSA 11.654, a szöveget Kiss Endre fordításában közöljük. Ld. Montinari (1986) 100-101. o.

${ }^{471}$ HA 1067. $\S$

${ }^{472}$ Spir (1873) I:28. „Das Bewußtsein ist sich selber unmittelbar gewiß: das Dasein des Denkens kann nicht geleugnet, noch bezweifelt werden, denn diese Leugnung oder dieser Zweifel sind eben selbst Zustände des Denkens oder des Bewußtseins, ihr eigenes Vorhandensein beweist also das, was sie in Abrede stellen, es benimmt ihnen folglich jede Bedeutung.“ (Az idézet Nietzschénél itt: KSA 11.640)

${ }^{473}$ Vö. Michael Steven Green: „Eternal recurrence in a Neo-Kantian context.” In: Kriterion. Vol. 54. No. 128. (2013) Online: http://www.scielo.br/scielo.php?pid=S0100-512X2013000200011\&script=sci_arttext
} 
Számunkra Green interpretációjának különösen két aspektusa érdekes. 1. Green értelmezésében a nietzschei filozófia lényegét tekintve falszifikacionizmus, amelyet Afrikan Spir gondolkodása inspirált, és amelynek értelmében a ,valóság” természete szerint folyamatos keletkezés, és mint ilyen, önmagában cáfolja a létezés különbözö elméleteit. Mindez összecseng „az idő atom-elméletének” az örök visszatérés közvetlen előzményeként történő interpretációjával, melyet korábban Whitlock és Crawford nyomán kíséreltünk meg felvázolni. Az örök visszatérés gondolatának tartalma a világ mint folyamatos keletkezés elgondolhatatlansága: a gondolkodás mint olyan eredendően hamisítás, amennyiben a folyamatos keletkezés csak a létezés kategóriáiban lehet elgondolható. 2. Spir és Nietzsche gondolatmenete azonban, mutat rá Green, egy alapvető tekintetben mégis különbözik: eltérő következtetésekre jutnak. Spir szerint az érzéki tapasztalás mindig a lét eredeti egységétől való elválasztottság tapasztalata; melytől szenvedünk. ${ }^{474}$ Azáltal, hogy a szenvedés révén az ember saját létezését a lét eredeti feltétlenségével és egységével szemben csökkent értéküként tapasztalja, a létezés keletkezéssel szembeni elsődlegességét ismeri el. Nietzsche ezzel szemben azáltal, hogy affirmálja a fájdalmat és az elégedetlenséget, épp ennek az ellenkezőjét állítja. Spir fenntartja e keletkezés realitását, mindössze annak a létezéssel szembeni másodlagosságát állítja, Nietzsche viszont a keletkezés kizárólagosságának tételezésével tagadja a létezést mint olyat. Míg tehát Spir falszifikacionista álláspontja szerint a valóság a folyamatos keletkezés, ez azonban meghamisítja a valóság „valódi” természetét, ami pedig nem más, mint a Lét feltétlen egysége, méghozzá a parmenidészi „Egy” értelmében, addig Nietzsche ennek pontosan az ellenkezőjét állítja. Szerinte a valóság természetéből adódóan maga a folyamatos keletkezés, melyet tehát éppen, hogy a lét kategóriáiban történő megragadás révén hamisítunk meg. Green értelmezésében az örök visszatérés gondolatának tulajdonképpen a következő kérdésre kell kielégítő magyarázattal szolgálnia: hogyan lehetséges bármilyen affirmáció a folyamatos változás kontextusában? Mit affirmálhatunk, ha a folyamatosan változó valóság természete szerint elgondolhatatlan? - Úgy véljük, ez az a kérdés, melynek megválaszolása segítségünkre lehet egyrészt Heidegger Nietzschekritikájának problematizálásakor, másrészt a deleuze-i interpretációval kapcsolatos polémiánk konkretizálásában.

Idézzük fel tehát „,az idő atom-elmélete” címen ismertté vált töredéket, még 1873-ból. Nietzsche ebben, Boscovich atom-elméletét alapul véve a következőket állítja: az idő csak térbeliként lehetséges, így a tér már mindig is időbeliként felosztott. Az idő-pontok erő-

\footnotetext{
${ }^{474}$ Vö. Spir (1873) I:214-215.
} 
középpontok, méghozzá a Boscovich-féle „materiális pont” értelmében - tehát azáltal vannak, hogy hatnak a többi tér/idő-pontra. Eközben minden pillanatban változáson mennek keresztül; az erő természeténél fogva folyamatban van, és soha nem ugyanaz; lényege a változás, és a változás egyet jelent az időbeliséggel; ez az ún. dinamikus világnézet lényege. Két egymással egybeeső pont között tehát nem lehetséges hatás; minden hatás actio in distans. Maga az idő sem folyamatos, mert nincs két egymással egybeeső időpillanat, az idő működési elve tehát szintén az actio in distans; a tér és az idő egyaránt diszkontinuum. Crawford azonban helyesen jegyezte meg, hogy Nietzsche értelmezésében az erö, maga is „materiális pont” lévén, folyamatosságában mégis pontszerü. Az erő tehát hatása tekintetében folyamatos, de maga ez a hatás egy diszkoninuus ugrás következménye, melynek révén az erö-középpontok [ti. a tér/idő-pontok] legyőzik a köztük lévő megszüntethetetlen távolságot. Az idő-pontok diszkontinuumát ugyanazek a pontok tér-pontokként tagolják; így az idő maga „telik”, ellenben a tér, a konstelláció tényének értelmében, mindig Ugyanakként tér vissza. Az örök visszatérés a tér/idő örök visszatérése, amely időként örök, és térként visszatérő. A „,materiális pontok” végtelen kombinálhatóságának lehetősége az „idő atom-elméletének” dinamikus erőtörvényével kiegészülve alátámasztja a hatalom akarása és az örök visszatérés gondolatpárjának „organikus”, vagyis a teleológia-kritika értelmében „célszerütlen” koncepcióját.

Whitlock szerint a Boscovich-féle atomelmélet tette lehetővé Nietzsche számára, hogy megfordítsa Spinoza panteizmusát azáltal, hogy megteremtette az ugyanannak örök visszatérése és a hatalom akarása tanításának elméleti előfeltételeit. Bár az „idő atomelméletét” tartalmazó töredéket Schlechta és Anders már 1962-ben közölték, Whitlock úgy véli, a Nietzsche-Boscovich hatástörténeti összefüggést a szakirodalom azóta sem vizsgálta kellő mélységben ${ }^{475}$ - ennek egyik oka pedig kétségtelenül az, hogy a sokáig egyeduralkodó Förster-Gast kiadás összeállításakor maga Peter Gast volt az, aki igyekezett csökkenteni Boscovich Nietzschére gyakorolt hatásának jelentőségét. Emlékezzünk vissza: Nietzsche éppen Gastnak említi 1882-ben, mekkora jelentőséget tulajdonít a dinamikus világnézetnek! $!^{476}$ A szerkesztők e „mulasztása” következtében egy újabb, mint látjuk,

\footnotetext{
475 Whitlock Schlechta és Anders munkája mellett a következő müveket említi: George J. Stack: Lange and Nietzsche. De Gruyter, Berlin - New York, 1983., Günter Abel: Nietzsche. Die Dynamik der Willen zur Macht und die ewige Wiederkehr. De Gruyter, Berlin, 1984., Babette E. Babich: Nietzsche's Philosophy of Science: Reflecting Science on the Ground of Art and Life. Routledge, New York, 1994. Az említettek közül Günter Abel volt az egyetlen, aki a Boscovich-Nietzsche és a Spinoza-Nietzsche relációk egymásahoz való viszonyát is vizsgálta.

${ }^{476}$ Ld. jelen írás 89. lj.
} 
alapvető fontosságú elemzési szempont veszett a feledés több évtizedes homályába. ${ }^{477}$ Azzal, hogy a két nietzschei alapgondolat közös eredetét a véges erő Boscovich-féle elméletében mutatja fel, a Boscovich-Nietzsche összefüggést hangsúlyozó megközelítés alapjában véve ellentmond Heidegger Nietzsche-interpretációjának. Nietzsche átvette Boscovichtól a véges erő gondolatát, a materiális pontokat azonban erő-középpontokká alakította, így konstruálva a teret az idő, az időt pedig a tér segítségével. Mindez tökéletes cáfolata Spinoza szubsztancialista metafizikájának, hiszen, mint láttuk, Boscovich elméletéből nem csak a szubsztancia, hanem a végtelen erő és a végtelen keletkezés lehetőségének tagadása is következik. Egészen pontosan, ugyan a szubsztancia tagadásából Boscovich következtetett az erő végességére, azonban a véges erőről a keletkezés végességére való következtetés, még ha indirekt formában is, de Spinozának köszönhető. Mindezek a belátások, állítja Whitlock, az örök visszatérés-gondolat közvetlen elözményének tekinthetők. Nietzsche számára tehát a mechanisztikus világnézet volt az a bizonyos utolsó lépés, amely szükségszerüen vezetett a dinamikus világnézet kialakulásához; ezt az átmenetet pedig a két említett gondolkodó, Boscovich és Spinoza tette lehetővé. Nietzsche 1884 második felében így ír:

Midőn saját, filozófiai genealógiámra gondolok, egyrészt korunk antiteleologikus, más néven spinozista mozgalmához érzem magam kapcsolódni, még azzal a különbséggel együtt is, hogy jómagam még a bennünk lévő »célt« és »akarást« is megtévesztőnek találom; másrészt a mechanisztikus mozgalomhoz (minden morális és esztétikai kérdés visszavezetése a fiziológiára, a fiziológiáé a kémiára, a kémiáé a mechanikára), még azzal az eltéréssel is, hogy én az »anyagra" gondolok, és Boscovichot olyan jelentőségü fordulópontnak tartom, amilyen Kopernikusz is volt; hogy én minden, a szellem önreflexiójából valókiindulást terméketlennek vélek, és az ösztönök vezérfonala nélkül nem bízom a kutatás sikerében. Nem a filozófia, mint dogma, hanem a kutatás előzetes szabályai. ${ }^{478}$

Míg tehát Boscovich elméletéből Nietzsche az erő és a keletkezés egyfajta cél nélküli végességére következtetett, addig a magát az erőt meghatározó belső akarat végtelenségének

\footnotetext{
${ }^{477}$ Erröl bővebben lásd: Whitlock (1996) pp. 203-206.

${ }^{478}$ KSA 11.266 „Wenn ich an meine philosophische Genealogie denke, so fühle ich mich im Zusammenhang mit der antiteleologischen, d. h. spinozistischen Bewegung unserer Zeit, doch mit dem Unterschied, daß ich auch »den Zweck« und »den Willen« in uns für eine Täuschung halte; ebenso mit der mechanistischen Bewegung (Zurückführung aller moralischen und aesthetischen Fragen auf physiologische, aller physiologischen auf chemische, aller chemischen auf mechanische) doch mit dem Unterschied, daß ich nicht an »Materie« glaube und Boscovich für einen der großen Wendepunkte halte, wie Copernicus; daß ich alles Ausgehen von der Selbstbespiegelung des Geistes für unfruchtbar halte und ohne den Leitfaden des Leibes an keine gute Forschung glaube. Nicht eine Philosophie als Dogma, sondern als vorläufige Regulative der Forschung."
} 
gondolatán keresztül a lehető legszorosabban kapcsolódik Spinoza affektus-elméletéhez. ${ }^{479}$ A két gondolatmenet együtt vezeti Nietzschét arra a következtetésre, hogy az anyag nem létezik, csak az erő, és hogy ez a világ, és benne a véges ember is a hatalom akarása - „és semmi más" ${ }^{480}$ Whitlock jól látja: még a perspektíva sem más, mint erő-középpont.

Nietzschénél, úgy tünik, minden egy irányba mutat: a végesség végtelenjébe; ,az új alapérzés: végleges mulandóságunk”, ${ }^{4} 1$ az „új világ-koncepció” pedig a következő:

\begin{abstract}
„A világ fennáll, nem pedig valami olyan, ami lesz, sem pedig, ami elmúlt. Vagy még inkább: lesz, és el is múlt, de sohasem szűnt meg keletkezni és elmúlni - e kettő révén tartja fenn magát. Önmagából él: ürüléke egyszersmind a tápláléka is. [...] Ha a világot meghatározott erőmennyiségként és erőcentrumok meghatározott számú sokaságaként kell elgondolnunk - és minden egyéb elképzelés homályosnak és haszontalannak bizonyult -, akkor ebből az következik, hogy a létezése nagy kockajátékában kiszámítható számú kombinációnak lesz alávetve. Végtelen időben minden lehetséges kombináció bekövetkezne egyszer, sőt, mi több, végtelen sokszor. És így minden kombináció és annak következő visszatérése között minden további lehetséges kombinációnak elő kellene állnia, és ezen kombinációk mindig ugyanabban a sorrendben kellene, hogy bekövetkezzenek, ez pedig abszolút azonos sorozatok körforgását jelentené: a világ mint körforgás, mely önmagát ismétli a végtelenségig, és amely a végtelenségig játssza játékát. Ez a koncepció nem egyszerüen mechanisztikus: mert ha az volna, akkor nem azonos esetek vég nélküli visszatérését eredményezné, hanem egyetlen végső állapotot. Mivel azonban a világ ezt sosem érte el, számunkra a mechanizmuson belül csak tökéletlen és pusztán ideiglenes hipotézis." ${ }^{482}$
\end{abstract}

Karl Popper The myth of the framework címü írásában a fizika és a metafizika viszonyának, a tudományelmélet egyik legfontosabb kérdésének kapcsán vizsgálja az anyag természetének

\footnotetext{
${ }^{479}$ Vö. Greg Whitlock: „Roger Boscovich, Benedict de Spinoza and Friedrich Nietzsche: the untold story.” In: Nietzsche-Studien 25. s. 200-220.

${ }^{480}$ Vö. HA 1027. §

${ }^{481} \mathrm{H} 49 . \S$

${ }^{482}$ KSA 13.374 sk. „Die Welt besteht; sie ist nichts, was wird, nichts, was vergeht. Oder vielmehr: sie wird, sie vergeht, aber sie hat nie angefangen zu werden und nie aufgehört zu vergehen - sie erhält sich in Beidem... Sie lebt von sich selber: ihre Excremente sind ihre Nahrung (...) Wenn die Welt als bestimmte Größe von Kraft und als bestimmte Zahl von Kraftcentren gedacht werden darf - und jede andere Vorstellung bleibt unbestimmt und folglich unbrauchbar - so folgt daraus, daß sie eine berechenbare Zahl von Combinationen, im großen Würfelspiel ihres Daseins, durchzumachen hat. In einer unendlichen Zeit würde jede mögliche Combination irgendwann einmal erreicht sein; mehr noch, sie würde unendliche Male erreicht sein. Und da zwischen jeder „Combination“ und ihrer nächsten „Wiederkehr“ alle überhaupt noch möglichen Combinationen abgelaufen sein müßten und jede dieser Combinationen die ganze Folge der Combinationen in derselben Reihe bedingt, so wäre damit ein Kreislauf von absolut identischen Reihen bewiesen: die Welt als Kreislauf der sich unendlich oft bereits wiederholt hat und der sein Spiel in infinitum spielt. Diese Conception ist nicht ohne weiteres eine mechanistische: denn wäre sie das, so würde sie nicht eine unendliche Wiederkehr identischer Fälle bedingen, sondern einen Finalzustand. Weil die Welt ihn nicht erreicht hat, muß der Mechanismus uns als unvollkommene und nur vorläufige Hypothese gelten.”
} 
problémáját. Mint mondja, a karteziánus hagyományban Descartes nyomán a kauzalitást érintkezés révén adódó hatásként, „lökésként” értelmezik; a mechanika alapelve, hogy nem lehetséges mozgás távoli pontok között. Leibniz elméletében a test kiterjedésként való, Arisztotelésztől származó értelmezése találkozik a kartezianizmus kauzalitás-felfogásával; nála a test az, ami képes ellenállni az erők hatásának: a test tehát taszítóerők által kitöltött tér. Leibniz teóriáját ezért tévedés lenne atomizmusként értelmezni, hiszen az atomok elmélete irreleváns a fő probléma, a kiterjedés kérdése tekintetében; a monászok elmélete tisztán metafizikai jellegü. Felmerül azonban a probléma, hogy egy, a leibnizi értelemben dinamikus rendszerben, melyben az erő nagysága a gyorsulással arányos, hogyan lehetséges a newtoni meghatározás szerint „rugalmatlan” testekként értett atomok közötti „lökés”. Ilyen körülmények között a „lökés” csak pillanatnyi, ugyanakkor véges gyorsulást jelenthet, amely azonban a végtelen erőmennyiségek tekintetében már egységnyi időn belüli végtelen gyorsuláshoz vezetne. Ha tehát, mondja Popper, igazolni kívánjuk a rugalmatlan atomok közti rugalmas „lökés” lehetőségét, magát az érintkezés általi hatás elvét kell feladnunk, és helyére a kis távolságon belüli hatásét állítanunk. Boscovich elméletének tudománytörténeti jelentősége tehát óriási. ${ }^{483}$

Míg Poppert inkább Boscovich elméletének ismeretelméleti-módszertani vonatkozásai érdekelték, addig Cassirer jóval „metafizikusabb” szempontokat vett figyelembe. ${ }^{484}$ Szerinte Boscovich, kétségtelen eredményei dacára, megrekedt azon az atomista hagyományon belül, melyet Démokritosz kezdett meg, és amelyet Nietzsche is folytatott, mikor az „érzékek előítéleteitől” való megszabadulást tűzte ki célul. Cassirer szerint az atomelméletek kezdettől fogva ugyanazon a problémán akadnak fenn: nevezetesen az energiamegmaradásén. Ha ugyanis az atom tökéletes és oszthatatlan egység, akkor az egymással való érintkezésben az atomok mindenképpen energiaveszteséget szenvednek; ha viszont nem ilyen az atom, akkor nem tekinthető szubsztanciális egységnek. A másik, nem kevésbé fontos probléma, mondja Cassirer, a folyamatosság kérdése, hiszen a sebességváltozás, amely két „szilárd” atom ütközésekor bekövetkezik, csak egyik nagyságból a másikba történő ugrásszerü, hirtelen átmenetként képzelhető el, hiszen mindkettőt a másik konkrét, véges mennyisége korlátozza.

\footnotetext{
${ }^{483}$ Vö. Karl R. Popper: The Myth of the framework. Routledge, London, 1994, pp.112-120. Popper ugyanitt, a 6. lábjegyzetben felhívja a figyelmet arra is, hogy bár Kant $A$ fizikai monadológia (1756) címet viselö harmadik disszertációjában már két évvel Boscovich természetfilozófiájának megjelenése (1758) előtt lefektette egy ilyen elmélet alapjait, az értekezést azonban a königsbergi egyetem visszautasította, Kant pedig később visszavonta az érintett téziseket; ezen felül a kanti koncepció Boscovichéhoz viszonyítva nagyon is vázlatos.

${ }^{484}$ A két álláspont különbségéröl lásd részletesen: Pietro Gori: „Boscovich's »philosophical meditations« in the history of contemporary thought.” In: Proc. Conferencence "Ruggiero Boscovich: astronomer, man of science and culture since 300 years from the birth". Ed. Giuseppe Pareschi. Memorie della Società Astronomica Italiana Supplementi. 2012. Vol. 75., pp. 282-292.
} 
Cassirer rámutat: mindkét ellentmondás abból az egyszerü tényből ered, hogy az atomokat, ezen eredetileg tisztán racionális gondolati konstrukciókat, olyan tulajdonságokkal ruházzák fel, melyeket az érzéki világ létezőinek analógiájára, ezen létezők tulajdonságaiból származtattak. Szerinte Boscovich a szubsztancializmust funkcionalizmussal helyettesítette, mikor az atom fogalmát puszta matematikai fogalommá redukálta. Míg azonban a hagyományos atomizmusban az atom anyag-forma egységének kostrukciós normáit egyedül a mechanika univerzális törvényei és alapelvei adhatják; a boscovichi elméletben a „materiális pontokat" kizárólag a pozíciójuk különbözteti meg egymástól, melyet a dinamikus akciók és reakciók rendszerében egymás számára határoznak meg. Az önálló és önazonos létezés (szubsztancializmus) helyét a „dinamikus együtt-létezés” (funkcionalizmus) veszi át, az eröpontok közti kölcsönös vonzásának és taszításának rendszerében. ${ }^{485}$ Annak dacára, hogy a „dinamikus szemléletben” rejlő funkcionalista tendencia a neokantianizmus számára elfogadhatatlan, a boscovichi elméletnek a szubsztancializmus kritikája kapcsán elért eredményeit maga Cassirer is elismeri.

Úgy véljük tehát, hogy Green jól látta: Spir elméletének voltaképpeni jelentősége abban áll, hogy számára az erő nem a változás oka, hanem a folyamatos keletkezés hajtóereje. Egy ilyen elképzelés ugyanis összecseng a boscovichi materiális pontok elméletével, melyek, mint láttuk, individuális erő-középpontok. Spir azonban azt állítja, minden olyan elmélet problematikus, amely kauzális gondolkodást feltételez, mert az összeférhetetlen a világ folyamatos keletkezésként való értelmezésével; hiszen a kauzalitás tételezése ismét csak a létezés keletkezéssel szembeni elsőbbségét hangsúlyozná - ez pedig, mondaná Heidegger, az ontológiai differencia elfelejtését jelentené. Ennek alapján tehát az egyedüli megoldás, ha felhagyunk a változás magyarázatára irányuló törekvéssel. Az örök visszatérés gondolata a spiri, „fundamentális antinómiából” levezetett konzekvens falszifikacionizmus fényében tehát a következöképpen értelmezendő: az örök visszatérésben a változás el van gondolva, amennyiben más változásokhoz kapcsolódik; de ahelyett, hogy ez a változás-folyamat a végtelenbe kulminálna, (ami a keletkezés és változás szférái közvetithetetlenségének elismerését jelentené), visszatér önmagába. Azzal, hogy a változást önmaga okaként és önmaga hatásaként mutatja fel, állítja Green Nietzschét idézve, ${ }^{486} a z$ örök visszatérés gondolata a lehetö legjobbanközelíti egymáshoz a keletkezést és a Létet. Ahogy Green maga

\footnotetext{
485 Vö. Ernst Cassirer: Substanzbegriff und Funktionsbegriff: Untersuchungen über die Grundfragen der Erkenntniskritik. Cassirer, Berlin, 1923, p. 157-159.

${ }^{486}$ Vö. HA 617, KSA 12:7[54] „Daß Alles wiederkehrt, ist die extremste Annäherung einer Welt des Werdens an die des Seins: Gipfel der Betrachtung."
} 
is utal rá, Heidegger éppen az ehhez hasonló kijelentések miatt állíthatta, hogy Nietzsche az örök visszatérés gondolata révén próbálta megalapozni az emberi végességet. Számunkra azonban elegendő oknak tünik a heideggeri interpretációban való kételkedésre Nietzsche saját megállapítása: az örök visszatérés a lehetö legközelebb viszi egymáshoz a keletkezést és a Létet - azaz kijelöli azt a határt, amit már nem lehet átlépni. Az örök visszatérés így az emberi végesség reprezentálhatatlan jellegének lehető legjobb reprezentációja - amely azonban ahhoz, hogy egyáltalán elgondolható legyen, önmagába kell, hogy visszatérjen. Vajon lehetséges-e ennél rettentőbb gondolat? Egyre valószínűbbnek tünik számunkra a feltételezés, hogy Heideggert és Deleuze-t ugyanaz vitte, ha szabad ezt mondanunk, „tévútra” Nietzsche filozófiájának értelmezésekor: az, tudniillik, amit utóbbi szándékosan hagyott kimondatlanul.

Azt gondoljuk, hogy amennyiben tehát Heidegger valóban itt, ezen a ponton értette félre Nietzschét, akkor a nietzschei gondolkodás, ismeretelméleti értelemben valóban egyfajta extrém falszifikacionizmusnak tekinthető. Feltételezzük, hogy Nietzsche gondolkodása hasonló ösvényen juthatott el a schopenhauerizmustól az örök visszatérés gondolatáig, mint amely Karl Poppert a Bécsi Kör verifikacionizmusától saját „kritikai racionalizmusához” vezette; a tendenciát pedig, amely ezt a hasonlóságot eredményezi és kifejezi, Popper szavaival „falszifikacionalista kriticizmusnak” nevezhetjük. Popper szerint a pozitivista filozófia nem képes számot adni a tudomány dinamikus karakteréről, mert kizárólag az igazolással, verifikációval éri be. A tapasztalás ugyanakkor nem igazolja, hanem cáfolja az elméletet, ezért a verifikacionizmus alapvetően hibás felfogás. Popper saját gondolkodását (melyet alapvetően a kanti kriticizmushoz tart hasonlónak) a filozófia öt, általa alapvetőnek tekintett alapvető irányultságával való viszonyában kifejezetten indeterminista, realista, racionalista gondolkodásnak tartja, a voluntarizmust és a nihilizmust pedig szánalomra méltó álláspontnak minősíti. ${ }^{487}$ A popperi falszifikacionizmus lényege, hogy mindig az adott elmélet esetleges hibáit keressük, az azt cáfolni képes eseményeket igyekezzünk előre jelezni, így a

\footnotetext{
${ }^{487}$ Vö. Karl R. Popper: Conjectures and refutations. The Growth of Scientific Knowledge. Basic Books, New York - London, 1962, p. 194. „We now have before us a list of five philosophical theories. First, determinism: the future is contained in the present, inasmuch as it is fully determined by the present. Second, idealism: the world is my dream. Third, irrationalism: we have irrational or supra-rational experiences in which we experience ourselves as things-in-themselves; and so we have some kind of knowledge of things-in-themselves. Fourth, voluntarism: in our own volitions we know ourselves as wills. The thing-in-itself is the will. Fifth, nihilism: in our boredom we know ourselves as nothings. The thingin-itself is Nothingness. So much for our list. I have chosen my examples in such a way that I can say of each one of these five theories, after careful consideration, that I am convinced that it is false. To put it more precisely; I am first of all an indeterminist, secondly a realist, thirdly a rationalist. As regards my fourth and fifth examples, I gladly admit--with Kant and other critical rationalists--that we cannot possess anything like full knowledge of the real world with its infinite richness and beauty. Neither physics nor any other science can help us to this end. Yet I am sure the voluntarist formula, 'The world is will', cannot help us either. And as to our nihilists and existentialists who bore themselves (and perhaps others), I can only pity them."
} 
falszifikálhatóság voltaképpen egy adott rendszer vagy elmélet „tesztelhetőségét” jelenti. Popper elmélete nem jelenti a metafizika elutasítását, mindössze a tudomány és a metafizika megkülönböztetését, melynek értelmében a tudományos állítások falszifikálhatóak, a metafizikaiak azonban nem. A racionalista verifikacionizmus bírálata azt jelenti, hogy nem fogadjuk el az értelmes és értelmetlen megkülönböztetését mint „demarkációs kritériumot” a tudományok tekintetében, helyette a falszifikálhatóságot tesszük meg ilyen feltételnek. ${ }^{488}$ Fontos megjegyeznünk, hogy évtizedekkel később, a kritikák hatására Popper beismeri: a falszifikálhatóság maga sem tekinthető végérvényesnek, ${ }^{489}$ ez azonban számunkra inkább erősíteni tünik az elmélet pozícióját. Amikor tehát a falszifikacionizmus az igazolhatóság kritériumát a „tesztelhetőségére” cseréli, ugyanazt a metafizikai előfeltevést bírálja, melyet, ahogy fentebb említettük, maga Nietzsche is problematikusnak tartott. „Ha így megtört az eddigi értékek zsarnoksága, és elpusztítottuk a »való világot«, az értékek új rendjének önmagától kell elkövetkeznie. [...] A látszólagos világ és a hazudott világ - az ellentét: utóbbit hívták eddig a »való világnak«, »igazságnak«, »Istennek«. Ezeket kell elpusztítanunk." ${ }^{490}$ Úgy véljük, hogy az eddigiek alapján Heidegger értelmezése, miszerint Nietzsche itt a saját, új „világrend” létrehozása iránti igényét jelentené be, egyre zavarbaejtőbbnek tünik. Figyelembe véve Nietzschének a „látszat” és a „valóság” hagyományos metafizikai megkülönböztetésével kapcsolatos határozott állásfoglalását, melynek jelentőségét a kanti sematizmussal szembeni polémia is jelzi, a Nietzsche által mondottakhoz érdemesebb a falszifikacionizmus szemszögéből közelítenünk. Ekkor a fentieket egész egyszerűen a következőképp érthetjük: a fennálló megszűnése mindig maga után vonja valami új keletkezését. Minden rendszer valamilyen értékrendet tükröz - épp ezért lehet bármilyen értékrend rendszer-alapító; hiszen ezzel mindössze annyit állítunk, hogy egy adott rendszeren belül minden részfolyamatot valamely meghatározott szabályszerüség irányít. Ha tehát megváltoztatjuk a szabályt, a rendszer elemei ugyanazok maradnak - de jelentésük megváltozik. Azzal, hogy Nietzsche tagadta a szubjektum-objektum megfelelés

\footnotetext{
${ }^{488}$ Vö. Karl R. Popper: The Logic of Scientific Discovery. Routledge, London - New York, 2002, pp. 3-26. illetve 57-73. Ebből következik Popper sajátos metafizikája, melynek lényege a valóság három szférára történő felosztása (,,a három világ elmélete”), melyek létükben függetlenek, de kapcsolatban állnak egymással. Az első fizikai tárgyak világa, a második a mentális-gondolati világ és a harmadik a gondolati tárgyak világa, a voltaképpeni ideális világ, melybe az ember-alkotta tudományos elméletek, müalkotások és intézmények egyaránt beletartoznak, és amelynek ki kell állnia a falszifikálhatóság mint demarkációs kritérium próbáját.

${ }^{489}$ Vö. Karl Popper: Realism and the Aim of Science. Routledge, London - New York, 1992, p. 185. „... no falsification can be absolute certain, owing to the fact that we can never be quite certain that the bacis states which we accept are true. (...) Take a basic statement or a finite set of basic statements. It remains forever an open question whether or not the statements are true: if we accept them as true we may have made a mistake. But no matter whether they are true or whether they are false, a universal law may not to be derived from them. Even if we knew for sure that they were true, a universal law could still not be derived from them."

${ }^{490}$ HA $461 . \S$
} 
lehetőségét (emlékezzünk vissza, még 1873-ban!), és hogy minden ilyen megfelelést, vagyis minden ,igazságot” metaforikusnak nyilvánított, ismeretelmélete véleményünk szerint határozottan falszifikacionista vonásokat mutat. Ugyanakkor azt is hozzá kell tennünk, hogy amíg Popper leszögezte: a metafizikával kapcsolatban nem alkalmazható a falszifikacionista kritérium, Nietzsche, aki a metafizikát mint erkölcsi világrendet kívánta átfogó kritika tárgyává tenni, ezen értékrend érték-tételező alapjának vonatkozásában éppen, hogy kívánatosnak, sőt, szükségesnek ítélte a fentiek értelmében vett „falszifikálást”. Ugyanitt jegyezzük meg azt is, hogy a „falszifikacionizmus” kifejezést Nietzsche ismeretelmélete kapcsán semmiképp sem abban az értelemben használjuk, mint például Maudemarie Clark, aki szerint az ,igazság” tagadása Nietzschénél a „,valóság” mint olyan falszifikációját, vagyis az ember-világ viszony abszolút bizonytalanságát jelentené; különösen, mivel Clark szerint mindennek oka, hogy Nietzsche végső soron elfogadta a kanti „magánvaló dolog” létezését. ${ }^{491}$ Nietzsche esetében nem egyszerüen korlátlan és végletes falszifikacionizmusról van szó, hanem a szubjektum-objektum megfelelés, a „helyes percepció” lehetőségének kétségbe vonásáról. Nietzsche mindenekelött annak lehetöségét tagadta tehát, hogy a szubjektum számára bármi is objekive adódhatna; ebben az értelemben pedig az „igazság” sem verifikációnak, sem falszifikációnak nem lehet tárgya. A metafora-teremtés lehetősége azonban minden, valóban „szabad” szellem számára adott.

\section{2. f. A differencia „radikális” elgondolhatatlansága: Jacques Derrida}

A falszifikacionizmus radikalizmusát talán csak a posztmoderné haladja meg; ez utóbbi értelmében ugyanis mindenfajta elmélet: korlátozás. Lyotard megfogalmazásában a posztmodern gondolkodás legáltalánosabb értelmében a „nagy elbeszélésekkel szembeni

\footnotetext{
${ }^{491}$ Vö. Maudemarie Clark: Nietzsche on Truth and Philosophy. Cambridge UP, Cambridge, 1990, pp. 63-93. Joshua Andersen hozzánk hasonlóan amellett érvel, hogy A nem-morálisan fölfogott igazságról és hazugságról több értelemben tekinthető „falszifikacionistának”, de ezek az aspektusok nem a Clark-féle falszifikacionizmustézist támogatják. A „falszifikáció” első szintje a hamisítás: annak feltételezése, hogy az ember minden dolgok mértéke lehet. Ezután következik a „maszkot öltés”: a látszat nem tévedés, hanem az életösztön megnyilvánulása. Éppen ez az életösztön diktálja, hogy megfeledkezzünk képzeteink érzéki eredetéről (ez a „grammatika tévedése”, melyre Nietzsche később is gyakran hivatkozik), arról tehát, hogy az érzéki eredetü, de a nyelv terminusaiba rendezett tapasztalatot nem a tényleges megfelelés, hanem a szociális ösztön ruházza fel értékkel; hogy tehát értékeink eredendően morális eredetủek - így tehát semmiképp sem objektívek. (Ld. Joshua Andersen: „Truth and Illusion beyond Falsification: Re reading On Truth and Lie in the Extra Moral Sense." In: Nietzsche-Studien 39. De Gruyter, Berlin - New York, 2010. pp. 255-281.)
} 
bizalmatlanságot”492 jelent. Meggyőződésünk, hogy Nietzsche támogatott volna egy ilyen típusú „gyanú-filozófiát”. Értekezésünknek és érvelésünknek ebben az utolsó szakaszában tehát egy ilyen értelemben „posztmodern” gondolkodó Nietzsche-értelmezését és saját, radikalitásában valóban minden határt eltörlő különbség-fogalmát szeretnénk az általunk paradigmatikusnak gondolt differencia-gondolkodásként, és par excellence reprezentációkritikaként felmutatni.

Mikor Derridát halála előtt nem sokkal arról kérdezték, lehet-e a dekonstrukciót a „kritikai szellem modern változatának” tekinteni, így válaszolt:

Igen, biztosan. A dekonstrukció ugyanakkor magát a kritika eszméjét is támadja. Nincs semmi kifogásom a kritikával szemben, sőt azt gondolom, hogy a lehető legmesszebb menően ösztönözni kell, de mindig van egy pillanat, amikor megkérdezem magamtól, honnan is jön. Röviden, a dekonstrukció nem redukálható a kritikára. Nem negatív, hanem az állító igen gondolata, a nagy nietzschei tradícióban. ${ }^{493}$

Derrida még magát a dekonstrukciót csak olyan alkalmakkor próbálta definiálni, amikor erre kifejezetten megkérték - és valljuk be, csak így volt következetes. A már említett interjúban például így fogalmaz:

„Elöször is, valami olyasmit kell elemezni, ami konstruált. Tehát nem természetes. Lehet az egy kultúra, egy intézmény, egy irodalmi szöveg, az értékek vagy fogalmak értelmezésének rendszere. Egyszóval constructum. Dekonstruálni nem annyi, mint rombolni. Nem negativ fellépés, hanemegy konstruált struktúra genealógiai elemzése, melyet rétegekre akarunk bontani. [...] Tulajdonképpen mindig is müködött, anélkül hogy tudomásunk

${ }^{492}$ Jean-François Lyotard: „A posztmodern állapot.” Ford. Bujalos István - Orosz László. In: A posztmodern állapot. Jürgen Habermas, Jean-François Lyotard, Richard Rorty tanulmányai. Szerk. Bujalos István, ford. Angyalosi Gergely et al. Századvég - Gond, Bp., 1993, 8. o. Alan D. Schrift a francia Nietzsche-kutatásból azokat a filozófusokat emeli ki, akiknek saját, legfontosabb témáit is a nietzschei gondolkodás ihlette; ilyenek szerinte Derrida, Foucault, Deleuze és Lyotard; az említett „közös témák” pedig a bináris gondolkodásmód kritikája, a hatalom és a tudás összefüggése, a keletkezés és a folyamatosság elsőbbsége a lét és az ontológia ellenében, kritériumok híján az ítélet szükségszerüsége. A fentiek közül, ahogyan Schrift is megjegyzi, Lyotard az, akit nem szokás ilyen egyértelmúen kapcsolatba hozni Nietzschével. Lyotard központi problémája, hogy a posztmodern perspektívából, mely nem fogadja el az átfogó világmagyarázatokat, hogyan lehetséges meghoznunk bármilyen, morális természetü döntést? A válasz a hatalom akarásának gondolatában rejlik, amely Lyotard szerint hasonlóan konstruált, mint a kanti Kritikának a képzelőerő konstitutív erejét tárgyaló gondolatmenete, azzal a különbséggel, hogy a hatalom akarása túllép az esztétikai dimenzió keretein, amennyiben ö maga a „hatás” mint olyan alapelve. Lyotard számára a nietzschei filozófia legnagyobb haszna kétségtelenül az „igazság”, és a belőle levezetett „kritérium” korábbi elméleteinek kritikája. (Vö. Alan D. Schrift: „Nietzsche's French legacy.” In: The Cambridge Companion to Nietzsche. Ed. Bernd Magnus, Kathleen M. Higgins. Cambridge UP, Cambridge, 1996, pp. 323-355.)

${ }^{493}$ Jacques Derrida: „Irásra vagyok ítélve.” Ford. Orbán Jolán. In: Jelenkor. 2005/10. 957-961. o. 
lett volna róla. Amióta például van esemény, a dekonstrukció ott van a levegőben. Az esemény nem tervezhető. Meglep, nyugtalanít, zavarba hoz. Az esemény a dekonstrukció." ${ }^{494}$

Derrida számára minden esemény, és minden esemény konstrukció, még maga a dekonstrukció is. A dekonstrukció egyedüli „elve” tehát az elvnélküliség, a definiálhatatlanság, sőt, maga a de-centrálás. Derrida úgy véli, minden struktúrának van egy középpontja, amely meghatározza a „struktúra játékának” szabályait, ezért annak elmozdításával (ami által egyszersmind megszünik középpontnak lenni) a struktúra „strukturálódási” folyamatát felszabadíthatjuk a középpont vonzása alól, ezzel pedig „megalapozatlanná”, veszélyessé - valódi ,játékká” tehetjük. Így tehát minden interpretáció mindig újabb interpretációra szorul, sőt megköveteli azt, hiszen a középpont nélküli struktúraként értett „egység” határai folyamatosan mozgásban vannak - tehát ő maga soha nem „ugyanaz”. Elmozdítása pillanatában azonban maga a középpont is egyfajta „nemhellyé” válik, magává az elmosódott határrá. Ez a folyamatosan elmozdulásban lévő „nemhely" [non-lieu] jelzi a különbözés kezdetét és befejezhetetlenségét. ${ }^{495}$

Derrida filozófiájának talán legismertebb, és kétségtelenül kulcsfontosságú terminusa az „el-különböződés” [diffèrance]. A kifejezést a francia „különbség” [diffèrence] szó írásképének megváltoztatásával nyerjük, a második „e” helyére „a”-t írva; a két szó fonetikailag semmiben sem különbözik, ugyanúgy ejtjük őket, azonban írva és olvasva ennek az egyetlen betünek a megváltoztatása jelentősen módosítja a jelentést. A ,differer” francia terminus jelentései közül a „különbözni” az ismertebb, a másnak lenni, a más-ként azonosíthatónak lenni értelmében; Derrida szerint a differencia, e-vel írva csak ezt a jelentést képes kifejezni, a differancia, a-val viszont a késleltetés, felfüggesztés, halogatás jelentéstöbbletét is hordozza. Az „el-különböződés” itt két betü, az 'e' és az 'a' között létrejövő „el-különbözés” mozgása, amely sem a beszédhez, sem az íráshoz nem tartozik, miközben azt az illúziót kelti, hogy a kettő különbözik. Az „el-különböződés” előbbi, mint a jelenlét és távollét metafizikai különbsége, amennyiben az eleve egy „el-különböződés” révén

\footnotetext{
${ }^{494}$ U. ott. Alan D. Schrift szerint Derrida az „eldönthetetlen” (ilyen például a „nyom”, a „khóra” vagy a „pótlék”, melyek nem konkrét meghatározások, talán még az „is-is”, vagy éppen „sem-sem” relációkban juthatunk hozzájuk a legközelebb) fogalmak segítségével voltaképpen magát a nyugati-metafizikus gondolkodást szeretné dekonstruálni. Vö. Schrift (1996) p. 328.

${ }^{495}$ Vö. Jacques Derrida: „A struktúra, a jel és a játék az embertudományok diskurzusában.” (ford. Gyimesi Tímea) In: Helikon, 1994/1-2. 21-34. o.
} 
lehetséges. ${ }^{496} \mathrm{Az}$ „el-különböződés” felold mindenfajta azonosságot, ezzel pedig nem csak az ellentmondás, hanem a megfelelés, vagyis a reprezentáció általában vett lehetőségét is kizárja. A kérdés az, mondja Derrida, milyen következményekkel jár annak feltételezése, hogy a lét „lényege”éppen az „el-különböződés” „el”-je?

Derrida úgy véli, Nietzsche és Freud gondolkodása nyomán vált valóban kétségessé a tudat önmagából adódó bizonyossága, és mindketten az „el-különböződés” motívumából indultak ki. Mindketten úgy vélték, a tudat erők harcának játéktere, amely erők azonban sosincsenek jelen - így a voltaképpeni cselekvés mindig „tudattalan”. Nietzschénél az erő differenciák és mennyiségek játékaként konstituálódik, mondja Derrida, ezért a nietzschei gondolkodás az általában vett azonosság-filozófia kritikáját jelenti. Míg Heideggernél a tudat még mindig egyfajta „önmagánál-lét”, Derrida úgy véli, mindenfajta nyelv, tehát maga a gondolkodás mint olyan, az „el-különböződés” révén konstituálódik és differenciálódik, a jelenlévő tehát soha nem tökéletesen önazonos, sokkal inkább „nyom”, amely jelenlétében valami másra vonatkozik, mint önmaga. A derridai interpretációban a nietzschei, örökké visszatérő „Ugyanaz” nem más, mint „maga az el-különböződés, [...] mint halasztó és kétértelmü átmenet az egyik differensből a másikba, az oppozíció egyik pontjából a másikba”. ${ }^{497} \mathrm{Az}$ így értett „differencia-gondolkodás” tehát a folymatos mozgásban-lét értelmében már mindig is ,aktív”.

A ,jelenlét metafizikájával” kapcsolatos derridai kritika lényege tehát, hogy a ,jelenlét” mint olyan - nincs; azonban, míg a heideggeri ontológiai differencia ,,anélkül tűnt el, hogy nyomot hagyott volna hátra", 498 az „el-különböződés” teljességgel a metafizika rendjén kívüliként igenis „van”; de éppen azáltal, hogy számunkra nincs. Ha tehát beszélni akarunk az „el-különböződésről”, azt csak a metafizika nyelvén tehetjük; azonban sem a beszéd, sem az „el-különböződés” nem szüntethető meg. Nem tagadhatjuk az ,elkülönböződés" létét, de be kell látnunk, hogy beszélni - bármiről is - csak a metafizika nyelvén tudunk. Az „el-különböződést” tehát nem kimondani, nem elgondolni, hanem „,igenelni kell [...], abban az értelemben, ahogyan Nietzsche nevetésként játékba hozta az igenlést. E nevetés és tánc óta, a minden dialektikától idegen igenlés óta merül fel kérdésként a nosztalgia másik arca, amit heideggeri reménynek fogok nevezni." ${ }^{499}$ Derrida maga is

\footnotetext{
${ }^{496}$ Vö. Jacques Derrida: „Az el-különböződés.” Ford. Gyimesi Tímea. In: Szöveg és interpretáció. Szerk: Bacsó Béla. Cserépfalvi, Bp., 1991, 43-63. o.

${ }^{497}$ U. ott 54-55. o.

${ }^{498}$ U. ott 59 . o.

${ }^{499}$ U. ott 62 . o.
} 
fontosnak tartja leszögezni: az „el-különböződés” nem azonos a heideggeri ontológiai differenciával, sőt nem is annak egy fajtája, hiszen Heideggernél az „esemény” voltaképpeni jelentősége abban állt, hogy az „,adomány adása” megtörténhessen - hogy a lét ,,jelenlevővé” válhasson. ${ }^{500} \mathrm{Az}$ „el-különböződés” tehát jelent negatív teológiát, hiszen kilép az ontoteológiaként értett filozófia keretei közül; a középpont nélküli struktúra játékterében tartva a gondolkodást. A középpont- és célnélküliségben egyetlen azonosság képzelhető el: a szükségszerűség és a véletlen azonossága. Nézetünk szerint tehát az „el-különböződés”: maga az örök visszatérés gondolatának „középpontja” helyén, a „nem-helyen” folyamatosan keletkező ,aktív differencia”.

Derrida szerint a logocentrizmus, a logosz, a szellem elsődlegességét hirdető ideológia összefonódik a prezentizmussal, az értelem tiszta és közvetítetlen jelenlétének elvével, ezt az összekapcsolódást fejezi ki a fonocentrizmus elve, amely a közvetítetlen belső hangnak az írással szembeni elsőbbségét nyilvánítja ki. A husserli fenomenológia hiányosságait tárgyaló $A$ hang és a fenomén címü írás első fejezetében így fogalmaz:

Két módon lehet eltörölni a jel eredendőségét, és különösen e két mozgás bizonytalanságára kell odafigyelnünk. Nagyon gyorsan és nagyon észrevétlenül mennek át egymásba. A jelet eltörölhetjük hagyományos módon, az intuíció és a jelenlét filozófiája módján. Ez úgy törli el a jelet, hogy másból származtatja, jelentéktelenné teszi a reprodukciót és a reprezentációt, egy puszta jelen utáni módosulást csinálva belőle. De mivel ez egy olyan filozófia - sőt, valójában a filozófia és a Nyugat történelme -, amely így ő maga hozta létre és fektette le a jel fogalmát, ezért a jel kezdettől fogva és értelmének legbelsejéig terjedően ennek a levezetésre és eltörlésre irányuló akaratnak a bélyegét hordja magán. Következésképpen, ha a klasszikus metafizika ellenében megpróbáljuk helyreállitani a jel eredendö voltát és nem származtatott jellegét, ezzel egy nyilvánvaló paradoxont teremtve, eltörlünk egy olyan jelfogalmat, amelynek egész története és egész értelme a jelenlét metafizikájának vállalkozásához tartozik. S ez a séma ugyanúgy érvényes a reprezentáció, az ismétlés, a különbség stb. fogalmaira is, ahogy az azokból kibontakozó minden rendszerre is. E séma mozgása ebben a pillanatban és még sokáig csak belülröl, egy bizonyos belsöben képes megdolgozni a metafizika nyelvét. Persze ez a munka már mindig is elkezdödött. Meg kellene ragadnunk, mi történik ebben a belsöben, ha majd a metafizika végét egyszer kimondjuk. ${ }^{501}$

Derrida azon meggyőződésének ad hangot, hogy a husserli fenomenológia, az „eidetikus redukció” minden szigora ellenére mégsem képes kivonni magát a ,jelenlét metafizikájának”

\footnotetext{
${ }^{500}$ Ld. u. ott Derrida jegyzetét.

${ }^{501}$ Derrida (2013) 65-66. o. (kiemelés tőlem, L. E.)
} 
hatása alól. Az „idealiter egység” Derrida szerint az „eleven jelen jelenléte”, ${ }^{502}$ de oly módon, hogy benne a jelenlét metafizikai tradícióján belül úgymond generációról generációra öröklődő „transzcendentális logosz” van jelen. ${ }^{503}$ (Ez nagymértékben összecseng az „ontoteológia” heideggeri elképzelésével.) Az idealitás teszi lehetővé az ismétlés egyáltalában vett lehetőségét, amennyiben biztosítja azt a jelenlétet, amelyben a tudat egyszerre van a tárgyánál és saját magánál. Derrida szerint a lényegi kérdés, melyet a husserli fenomenológia kapcsán fel kell tennünk, a következő: vajon az idealitás ily módon az „élet” lehetősége is-e egyben? Husserl fenomenológiája egyetlen területet hagy „lefedetlenül”, a „valódi” és az „,ideális” különbségét - és éppen ez az a terület, ahol az életet sejteni lehet.

[...] radikális különbség, amelynek semmi köze egyetlen más különbséghez sem; egy olyan különbség, amely ténylegesen nem különböztet meg semmit, amely nem választ külön egyetlen létezöt, egyetlen élményt, egyetlen meghatározott jelentést sem; mégis különbség, amely anélkül, hogy elváltoztatná, mégis megváltoztat minden jelet és amely egyedüli biztosítója a transzcendentális kérdés lehetőségének. Vagyis a szabadságnak magának. Alapvető különbség tehát, amely nélkül egyetlen különbségnek mint olyannak sem lenne se esélye, se értelme a világban megjelenni. ${ }^{504}$

Úgy véljük, Derrida az ontológiai fenomenológia-koncepció kritikájakor bukkan rá arra a problémára, amely azután egész későbbi gondolkodása központi helyét elfoglalja, tudniillik az emberi tudatnak ezen végső, radikális különbség megragadására való képtelenségére. Heideggertől eltérően azonban, ahelyett, hogy a Semmi lehetőségétől szorongana, Nietzschével együtt a veszélyesebb utat választja.

Ezzel kapcsolatban érdekes adalékkal szolgál Gianni Vattimo, akinek argumentációja a nietzschei és a heideggeri differencia-gondolkodás közti alapvető különbségről és annak okáról számunkra roppant meggyőző. Vattimo a következőképpen érvel: a differencia-

\footnotetext{
${ }^{502}$ U. ott 11 . o.

${ }^{503}$ Joanna Hodge kiválóan összegzi a problémát: Derrida azért tartja problematikusnak a fenomenológia husserli koncepcióját, mert az maga is az „,idea” kanti fogalmára épül. A kérdés tehát az, hogy vajon Kant és Husserl szükségszerüen gabalyodtak-e az „eredet értelmének” és az „értelem eredetének” paradoxonába, vagyis, hogy vajon feloldható-e az értelem és a gondolkodás általános „transzcendentális illúziója”. Ez ugyanis nem teszi lehetővé a „tiszta” eredet artikulálását, hiszen az redukció minden kísérlete éppen az eidosz, a lényega priori jellegén fut zátonyra. Ugyanis még az eidosz „omni-temporális” jelentése is egy olyan eredetre utal, ami mindig is eljövőben van, tehát már eleve nem egy eredet. Ezt a kezdeti sokféleséget Derrida az epikuroszi atomizmusra adott a nietzschei, illetve freudi válaszok terminusaiban tartja elgondolhatónak, és elgondolandónak. In: Joanna Hodge: Derrida on Time. Routledge, New York, 2007, pp. 49-66.

${ }^{504}$ Derrida (2013) 17. o.
} 
filozófiára már jóval azelőtt hatott Nietzsche, hogy tudatában lett volna ennek; maga a par excellence differencia-gondolkodás viszont értelmezhetetlen lenne Heidegger nélkül. Implicit módon már a Lét és idő keletkezésekor küszöbön áll a különbség kérdése, hiszen a tény, hogy a Lét értelmére irányuló kérdést fel kell tenni, egyúttal azt is jelenti, hogy a létezők felől nem adható rá kielégítő válasz. Vattimo szerint az ontológiai differencia Heidegger számára nem az alapot jelenti, hanem a voltaképpeni problémát, ezért a historicista és neokantiánus értelmezések egyaránt tévesek. A differencia heideggeri fogalma egyszerre fejez ki szubjektív és objektív genitivust, azaz, hogy a Lét objektivitása a létező szubjektivitásában nyilvánul meg, ily módon mindkettő a másik „birtokában” van. Az ontológiai differenciára való emlékezés tehát nem egyszerüen a Lét és a létező különbségének felismerése, hanem magának a differencia problémájának a felidézése, a birtokviszony szubjektív és objektív dimenziójának egyidejü figyelembe vételével. A kortárs francia differencia-filozófia, melynek központi témája Nietzsche, és amely a heideggeri differencia-gondolkodás terminusaiban pozicionálja saját magát, mégsem hajlandó elfogadni Heidegger Nietzsche-értelmezését; ennek oka pedig éppen a „differencia” fogalmának Heideggerétől eltérő értelmezése. Míg Heidegger Nietzschét nem is tekinti differencia-filozófusnak (lévén gondolkodása egyfajta „kifordított platonizmus”), a franciák felhívják a figyelmet, hogy Nietzsche már A tragédia születésében is „visszaemlékezik” arra a bizonyos elfeledett ontológiai differenciára. Vattimo szerint Nietzsche költői, metaforikus nyelvezete már eleve az ontológiai differencia nyelvét beszéli, hiszen már a „Dionüszosz” név használata is a metafizika terrénumán kívül helyezi a diskurzust. Nietzsche nyelvezete tehát eleve a differencia diskurzuson belüli jelentőségének felismeréséről, illetve működtetéséről árulkodik. A reprezentáció-kritika nézőpontjából Nietzsche semmiképp sem képekben „fejezi ki magát”; stílusa sokkal inkább az elmélet gyakorlatba történő átültetéséről tanúskodik. Ahogy láttuk is, a derridai „középpont nélküli struktúrában" a játék mindig más és más, de maga a struktúra mindig ugyanolyan marad: „,középpont-nélküli”, „el-különböződő”. Azonban a derridai „struktúra” nem egyenlő a „létező egészével”! Úgy tünik, mondja Vattimo, mintha Heidegger sokkal nagyobb hangsúlyt fektetett volna a „meghaladás” momentumára, mint maga Nietzsche; hiszen folyamatosan azzal érvel, hogy a differenciára való visszaemlékezés nem lehetséges, amíg az „egész” metafizikai kontextusában gondolkodunk. Az ontológiai differencia a Létnek magának az a különleges jellemzője, hogy az elrejtettségben marad, amint megjelenhetne; ez az ,,adottként eltitkolt" jelleg azonban a metafizika mint olyan legsajátabbja - és pontosan ebben az értelemben állíthatjuk, hogy a metafizika a Lét története. Ha azonban mindezt komolyan vesszük, és hozzátesszük a Lét Heidegger által is hangsúlyozott eseményjellegét, akkor 
felmerül a kérdés, hogy vajon a differencia szerkezetén belül a fentiekben jelzett genitivus pusztán objektíve, vagy objektíve is értendő. A metafizika ugyanis ekkor valóban a Lét története lenne, hiszen a Lét ekkor ténylegesen a metafizika történetéhez tartozna, és nem csak a metafizika vége felől tekintve, hanem annak meghaladása értelmében is. A metafizika meghaladásának lehetősége tehát nem csak, hogy a Lét, hanem az ontológiai differencia berekesztődését is jelentené. Vattimoban felmerül a kérdés: nem lehetséges, hogy Heidegger megérezte, hogy a metafizika végének mint a Lét valóságos felszámolásának elmélete nagyobb kárt okozna, mint ha pusztán az ontológiai differencia elfelejtéséről beszélne? Az előbbi esetben ugyanis az utóbbi többé már nem pusztán Lét és létező különbségének elfelejtését jelentené, hanem magának a különbség „eseményének” elfelejtését; az arról való elfeledkezést, miért is van a különbség egyáltalán. ${ }^{505}$

„A dekonstrukció mindenekelőtt a tisztelet és a szeretet gesztusa”,506 - mondta Derrida a már említett, halála előtt készített interjúban. Amikor valamit dekonstruálunk, a „másik” felé fordulunk a tisztelet és az elismerés aktusával - tehát az egyediség értelmében vett egységként tekintünk rá. Derrida azt veti Heidegger szemére, hogy mikor Nietzsche gondolatainak „egységéről” beszélt, azt nem magának Nietzschének, hanem a nyugati metafizika hagyományának mint egésznek tulajdonította. A dekonstrukció a szerző nevét, mint tulajdonnevet mindig egy gondolat nevének tekinti, ilyen értelemben tehát a „Kicsoda?” kérdésére az adott személy gondolkodásában, nem pedig a róla szóló biográfiai adatok rengetegében kell keresnünk a választ. Veszélyes módja ez az értelmezésnek, hiszen fennáll az esélye mind annak, hogy a személy eltűnik a maszkok sokaságában, mind annak, hogy Heiddeggerhez hasonlóan egyszerüen megszüntetjük a tulajdonnevet, mikor a gondolkodás tárgyából a név „lényegét” próbáljuk meghatározni. Heidegger oly mértékben irtózott az „életfilozófiától”, hogy végül magát Nietzschét is a ,jelenlét metafizikájának” terminusaiban gondolta el, egy adott gondolati tartalom képviselőjévé degradálta. Azonban, mondja Derrida, Nietzsche azt kívánta tőlünk: „váljunk kísérletekké!”; ${ }^{507}$ úgy vélte, a „,szabad szellem” élete

\footnotetext{
${ }^{505}$ Vö. Gianni Vattimo: The Adventure of Difference. Philosophy after Nietzsche and Heidegger. Trans. Cyprian Blamires, Thomas Harrison. Johns Hopkins UP, Baltimore, 1993, pp. 62-84.

${ }^{506}$ Derrida (2005) ???

${ }^{507}$ Ld. H 432. § „Kísérletező módon kell bánnunk a dolgokkal; hol gonosznak, hol jónak kell lennünk velük; igazságosan, majd szenvedélyesen, majd hűvösen kell viselkednünk velük szemben. [...] Mi, kutatók, mint minden hódító, felfedező, hajós és kalandor, a vakmerő moralitás emberei vagyunk, meg kell békülnünk azzal, ha egészében véve gonosznak tekintenek bennünket.”; illetve KSA 13.492 „Woran ich meines Gleichen erkenne. - Philosophie, wie ich sie bisher verstanden und gelebt habe, ist das freiwillige Aufsuchen auch der verwünschten und verruchten Seiten des Daseins. Aus der langen Erfahrung, welche mir eine solche Wanderung durch Eis und Wüste gab, lernte ich Alles, was bisher philosophirt hat, anders ansehn: - die verborgene Geschichte der Philosophie, die Psychologie ihrer großen Namen kam für mich ans Licht. »Wie viel Wahrheit erträgt, wie viel Wahrheit wagt ein Geist?« - dies wurde für mich der eigentliche Werthmesser. Der Irrthum ist
} 
folyamatos, önmagán való kísérletezés, így nem csak élete, hanem megismerése is - kísérleti jellegü. Ha tehát ezt komolyan vesszük, akkor az élet maga a megismerés kísérlete, és ekként már mindig egyszerre kívül és belül is kell lennie önmagán. Heidegger tehát maga is a logocentrizmus (vagyis az „ontoteológia”) büvkörében maradt. ${ }^{508}$ A ,szabad szellem” nem igazolni akarja magát, hanem a veszélyes, kockázatos életre mond igent, melyben folyamatosan próbára kell tennie önmagát, de szigorúan a falszifikáció értelmében; egy ilyen élet pedig maga is középpont nélküli struktúra, míg a metafizikáé „axiomatikus struktúra”, „különös kör [...] amely egyedülálló szöveget egyesítő gondolkodás, illetve végső fokon a lét, a lét megtapasztalásának egyedülálló neve körül gyülik egybe. [...] Talán ez az, amit a Nietzschék megkérdőjeleztek: a logosz legeinje, ${ }^{509}$ a logika összegyüjtése. ${ }^{, 510}$ Derrida szerint tehát Heidegger tévedett: Nietzsche nem tartozik, nem tartozhat a ,jelenlét metafizikájának” történetéhez, amely éppen ezt a „lefedetlen”, „el-különböződő” területet akarja kisajátítani, azonosságokban megragadni; már csak azért sem, mert Nietzsche metaforikus igazsága mindig elillanna az ilyen kisajátítások elől. De főként azért nem, mert a ,jelenlét metafizikája" nem ragadható meg az általa strukturált oppozicionális struktúrában - nem tudja ugyanis megelőzni önmagát. ${ }^{511}$ Így a metafizika „meghaladása” a heideggeri értelemben, és pontosan az ontológiai differencia radikalitása és eltörölhetetlensége miatt - nem is lehet lehetséges. Azért nem, mert nem áll fenn az analógia lehetőségét előfeltételező oppozicionális viszony a fizikai és a metafizikai, a reális és az ideális, a test és a lélek, vagy a látszat és a valóság között. Az ontológiai differencia azonban teljesen „elfelejteni” sem engedi magát így a metafizika beteljesítése, vagyis a jelenlét tökéletes reprezentáció-elmélete ugyanígy lehetetlen. Ebben áll a reprezentáció kegyetlensége - és az emberi létezésé is.

Derrida, Kant A filozófiában meghonosodott emelkedett hangnemröl címü írására reflektálva, ,apokaliptikus hangnemnek” nevezi azt a beszédmódot, amely a metafizikus gondolkodást jellemzi, és amely valamiféle, a fizikai világon túl rejtőző „titok” leleplezésének

eine Feigheit... jede Errungenschaft der Erkenntniß folgt aus dem Muth, aus der Härte gegen sich, aus der Sauberkeit gegen sich... Eine solche Experimental-Philosophie, wie ich sie lebe, nimmt versuchsweise selbst die Möglichkeiten des grundsätzlichen Nihilismus vorweg: ohne daß damit gesagt wäre, daß sie bei einem Nein, bei einer Negation, bei einem Willen zum Nein stehen bliebe. Sie will vielmehr bis zum Umgekehrten hindurch bis zu einem dionysischen Jasagen zur Welt, wie sie ist, ohne Abzug, Ausnahme und Auswahl - sie will den ewigen Kreislauf, - dieselben Dinge, dieselbe Logik und Unlogik der Knoten. Höchster Zustand, den ein Philosoph erreichen kann: dionysisch zum Dasein stehn -: meine Formel dafür ist amor fati..."

${ }^{508}$ Vö. Jacques Derrida: „Két kérdés aláírásokat értelmezve. (Nietzsche/Heidegger)” Ford. Somlyó Bálint, Szücs Tamás. In: Literatura. 1991/4. 322-335. o.

${ }^{509}$ A görög ,,legein” szó gyökere a görög „,lego” (beszélni), melynek proto-indoeurópai szótöve, a „,leg”, a beszéd és az összegyüjtés jelentésárnyalatával is rendelkezik.

${ }^{510}$ Derrida (1991) 332. o.

511 Vö. Jacues Derrida: „Èperons. Nietzsche stílusai.” Ford. Sajó Sándor. In: Athenaeum. 1992. I/3. A francia Nietzsche-recepció. 172-213. o. 
„apokaliptikus” lehetőségét sugallja. Kant rövid, de határozott hangú szövegében azt állítja, hogy a filozófia halálát bejelentő eszmefuttatások maguk siettetik annak bekövetkeztét, méghozzá a néha az ostobaságig misztikus hangnemük révén, mellyel minduntalan valami „titok” lappangását sejtetik. Derrida szerint a hangnem mindig ,apokaliptikus”, vagyis „eszkatologikus”, amennyiben a látszat ellentéteként tételezett valóságról mint a meglévőből kirekesztettről, azon „túliról” szól. Nem más ez, mondja, mint ,a fogalmak ugrása az elgondolhatatlanba". ${ }^{512}$ A kimondott és kimondatlan-kimondhatatlan (ti. az elgondolható és az elgondolhatatlan) közti határ illékonysága teszi igazán veszélyessé a beszédet és a gondolkodást; ugyanis az eszkatológia, az apokalipszis lehetősége valójában nem a hangnem függvénye, hanem magáé a beszédé, a gondolkodásé. Az apokalipszis azonban lényege szerint nem más, mint folyamatos önmagát-elhalasztás; így ,a katasztrófa itt talán maga az apokalipszis katasztrófája, fordulata és visszahajlása és vége, vég nélküli berekesztődés, vég nélküli vég." 513

A kegyetlenség színháza című rövid írásában Derrida Antonin Artaud színházkoncepcióját tárgyalja. ${ }^{514}$ Artaud vezérelve a következő: ,a világos gondolat - a színházban és másutt egyaránt - befejezett, tehát halott gondolat". ${ }^{515}$ A tökéletes ábrázolásra való törekvés tehát mindig az életet áldozza fel a szellem oltárán, a színháznak mégis erre kell törekednie Artaud ezért nevezi saját tervezetét, melyet egyébként kiáltványként fogalmazott meg, a „könyörtelen színház” tervének. Ha a müvészettől katarzist várunk, és ha a katartikus élményben önnön végességünkkel szembesülünk, akkor valóban: mi lehetne kegyetlenebb a tökéletes reprezentációnál? Vajon mi a rosszabb? Ha sikerül, vagy ha nem? Vajon nem a lehető legkegyetlenebb-e egy olyan gondolkodásmód, amelynek centrumában a kezdetektől fogva az erre irányuló törekvés áll? Vajon elképzelhető-e nagyobb tragédia annál, mint hogy az emberi gondolkodás sorsa, hogy a metafizika foglya maradjon? És vajon van-e nehezebb feladat a fogoly ember számára, mint hogy mégis azt kiáltsa: amor fati?

Úgy véljük, hogy az „el-különböződés” alapmozgása által a megfoghatatlanságban tartott derridai differencia-koncepció révén férkőzhetünk a lehetö legközelebb a nietzschei gondolkodás mélyén munkáló szándékok feltárásához. Természetesen érthetőek azok a Derridával szembeni aggályok, melyek értelmében a dekonstrukció voltaképpen nem más,

\footnotetext{
512 Derrida-Kant (1993) 51. o.

${ }^{513}$ U. ott 91 . o.

${ }^{514}$ Ld. Jacques Derrida: A kegyetlenség színháza. Paule Thévenin-nek. Ford. Farkas Anikó, Ivacs Anikó, et al. Online: http://www.literatura.hu/szinhaz/derrida.htm

${ }^{515}$ Antonin Artaud: „A Kegyetlen Színház.” Ford. Betlen Gábor. In: U. ő: A könyörtelen színház. Ford. Betlen Gábor. Gondolat, Bp., 1985, 99. o.
} 
mint a transzcendentális gondolkodásmód egy újabb változata, és ily módon maga is metafizikus. Ekkor azonban azt állítanánk, hogy a „metafizikus gondolkodás” kapcsán kizárólag az arisztotelészi logika szellemében tehetünk kijelentéseket: tudniillik azt kellene mondanunk, hogy egy gondolkodásmód vagy metafizikus, vagy nem, harmadik lehetőség vagy esetleges kompromisszum szóba sem jöhet. Mindez azonban már eleve feltételezi, hogy a „metafizikát” magát is „metafizikusan” vizsgáljuk, tehát a „létezőt mint létezőt” fogjuk vallatóra. De vajon mennyiben változtat a helyzeten, ha a kérdezés valami olyanra irányul, ami egyedül a nem-létezésben „van”? Ebben az esetben ugyanis semmiképp sem beszélhetnénk „metafizikáról”, de nem is tagadnánk azt. Ebben az esetben a metafizika nyelvén, melyen egyedül képesek vagyunk beszélni és gondolkodni, eleve csakis kérdéseket tehetünk fel. Ebben az értelemben ugyanis semmi sincs, hanem minden már volt és majd lesz is, és egyedül ez az örökké visszatérő kérdésesség az, ami mindig „Ugyanaz”. 


\section{Összegzés}

Az értekezés első részében azt állítottuk, az általunk ,aktív differenciaként” aposztrofált, önmagát minden pillanatban feloldó és e feloldásban egyszersmind újra is termelő, radikális különbség volt az az erő, amely már a Fátum és történelem ifjú szerzőjében gyanút ébresztett az értékek értékét illetően. Ez volt az a gyanakvás, amely nem engedte, hogy kitartson Kant és Schopenhauer mellett, és amely a látszat-valóság dualizmusát Apollón és Dionüszosz harmóniájában próbálta meg feloldani. Az „aktív” különbség ereje oldotta az „,igazságot” metaforákká, pluralitássá, perspektivikus struktúrává, és kényszerítette a „szabad szellemet” arra, hogy önmaga számára való kísérletté váljon úgy, hogy ebben a folyamatos keletkezésben többé már ne a Test és a Lélek elválasztottságában, hanem a „célszerütlen” organizmus egységében, minden pillanatban Önmaga legyen. A differenciának ez a megszüntethetetlen, felfüggeszthetetlen aktivitása révén az minden, ami: a „hatalom akarása és semmi egyéb”, mint a soha véget nem érő keletkezésben folyamatosan igenlő önmagátakarás. Az amor fati ennek a kegyetlen, ugyanakkor heroikus életnek az igenlése, melyre csak az embert fölülmúló ember képes, és amelynek az ezerarcú Dionüszosz lehet az egyedüli „istene”, Zarathustra pedig a prófétája. Az „aktív differencia” az a kimondhatatlan gondolat, ami kimondása pillanatában megszünteti magát, és amely az ember, a világ, az Élet „sorsaként” mégis folyamatos kérdésként jelenti be magát az örök visszatérésben.

A második részben először Heidegger Nietzsche-kritikájának főbb téziseit ismertettük; és csak mindezek után tartottuk elérkezettnek az időt arra, hogy az első rész exkurzusaiban már elöre jelzett hatástörténeti összefüggések részletes kibontására támaszkodva saját téziseink mellett érveljünk. Azok a törekvések, melyek a nietzschei gondolkodást a paradigmatikus differencia-filozófiaként igyekeznek igazolni ezzel egyszersmind azt is állítják, hogy Nietzschének igenis sikerült a metafizikai tradíció meghaladása. Gilles Deleuze számára például Nietzsche jelenti a valódi kritikai fordulatot a filozófiában, szerinte ugyanis az átfogó kritika igényével elsőként fellépő kanti filozófia éppen az érték értékének eredetét mulasztotta el megkérdőjelezni. Azonban, mint azt a nietzschei örök visszatérés-gondolat „szelektív ontológiaként” történő interpretációja is mutatja, Deleuze végső soron magát Nietzschét is az érték-központú filozófiai hagyományba zárta. Azzal ugyanis, hogy a nihilizmust a heideggeri-gadameri értelemben ${ }^{516}$ a metafizika önfelszámolásaként, magát a

\footnotetext{
${ }^{516}$ Vö. Gadamer (1997) 17-41. o.
} 
nietzschei filozófiát pedig ezen önfelszámoló tendencia konkrét betetőzéseként értelmezi, már eleve a „hermeneutikai körben”,517 tartja az általában vett értéktételezést mint olyat. A „hermeneutikai kör” pedig, mint láttuk, nem más, mint a „logosz legeinje”, vagyis az ontoteológia müködési elve. Deleuze-nél az aktivitás az önmagát akaró hatalom ön-élvezete önmagába záródó, a Lét mint középpont köré gyülő struktúra; a deleuze-i különbség-filozófia tehát a differenciának a számunkra túlságosan „gyenge”, „mérsékelt” koncepciójával dolgozik.

A nietzschei életmü differencia-gondolkodásként történő rekonstrukciójával tehát mi magunk sem azt kívántuk bizonyítani, hogy Nietzschének sikerült a metafizika meghaladása. Ellenkezőleg: arra próbáltunk rájönni, vajon mi lehet az oka annak, hogy „a” differenciafilozófiának mindezidáig nem sikerült egyetértésre jutnia ebben a kérdésben. Azt azonban nem állíthatjuk, hogy Nietzsche, úgymond, „,belül rekedt” volna a metafizikus tradíción. Jelen értekezés, mint értelmezési kísérlet, tehát egy olyan, harmadik lehetőség után kutatott, mely mégis „meghagyná jogaiban” nem csak a különbség-központú Nietzsche-olvasatokat, hanem magát a reprezentáció-kritikára épülő differencia-filozófiát is. Arra a következtetésre jutottunk, hogy amennyiben az értelmezés nem vet számot a nietzschei Kant-kritika voltaképpeni jelentőségével, vagyis amennyiben nem vesz tudomást a reprezentáció-kritika központi szerepével a teljes nietzschei gondolkodás tekintetében, nem beszélhetünk par excellence differencia-gondolkodásról. Ez esetben ugyanis éppen a differenciának az a nem egyszerűen destruktív, hanem a derridai értelemben „de-konstruktív” aspektusa nem jut kifejezésre, amely adifferenciát mint differenciát egyáltalában lehetővé teszi. Úgy tűnik tehát, hogy amíg a differencia-gondolkodás kimerül abban, hogy egyszerüen egyfajta univocitáselméletté degradálja az örök visszatérés gondolatát (ahogyan Heidegger és Deleuze tette), nem csak a nietzschei filozófiát, hanem önmagát is a metafizika „ontoteológiai” hagyományán belül tartja.

Az értekezés első része, mindezt figyelembe véve, megelégedett azzal, hogy megkísérelje oly módon rekonstruálni a nietzschei filozófiát, hogy abban lépten-nyomon a Nietzsche által implicit módon, ugyanakkor radikalitásában „elgondolt” differencia nyomait mutassuk ki - mégpedig az „aktív differencia” munkafogalmának bevezetésével, ami által mindvégig a gondolkodás folytonosságát, vagyis a derridai, azaz nem-heideggeri értelemben vett egységét tartottuk szem előtt. A látszólag önmagának ellentmondó állítás azonban csak

${ }^{517}$ IM 300. o. 
akkor nem ténylegesen inkonzisztens, amennyiben a heideggeri interpretáció, melynek értelmében a nietzschei gondolkodás az onto-teológia értelmében vett metafizika, nem igazolható. Többször hangsúlyoztuk, hogy távolról sem tévedéssel vádoltuk Heideggert; ez antagonisztikus ellentétben állt volna egy olyan kísérlettel, mely a nietzschei filozófiát szélsőségesen falszifikacionista jellegü metafizika-kritikaként kívánja értelmezni. Úgy véljük, hogy az örök visszatérés gondolatában kulmináló nietzschei æeuvre kapcsán egész egyszerüen nem az a helyes kérdés, hogy meghaladta-e vagy sem a metafizikát, hanem az, hogy amennyiben egyik válasz mellett sem szeretné elkötelezni magát, milyen egyéb lehetősége marad az értelmezőnek. E dilemmára vonatkozóan számunkra a reprezentáció-kritikára alapozott, tendenciózusan falszifikacionista, radikális differencia-filozófia kielégítő alternatívának tünik. Ennek értelmében tehát Nietzsche nem rekedt „belül” a metafizikán, de nem is haladt rajta „túl”; ehelyett olyan erejü kritikával lépett fel ellene, amely egészen odáig merészkedik, hogy minden kérdést feltegyen, ugyanakkor lemondjon a válaszokról. Az emberi létezés „végső” kérdései ugyanis természetüknél fogva megválaszolhatatlanok, de ugyanezen szükségszerüség révén mégis mindig „felmerülnek”. Az Übermensch feladata nem a válaszadás, hanem a megválaszolhatatlanság igenlése; a folyamatosan önmagát megkérdőjelező létezés pedig csak az örök visszatérés olyan struktúrájában lehetséges, amely a változáson kívül nem tủr meg magában semmi állandót.

A nietzschei filozófia reprezentáció-kritikán alapuló, szélsőségesen falszifikacionista differencia-gondolkodásként történő interpretációja során munkafogalmunkat, az „,aktív differenciát" a metafizika-kritika voltaképpeni lehetőségét megteremtő gondolkodásmód alapelemének tekintettük, amelynek ,lényege” éppen abban áll, hogy lehetetlenné tegye a statikus önazonosság, az abszolútumokban rögzített „,valóság” elgondolását. Ennyiben tehát nem beszélhetünk a metafizika meghaladására tett nietzschei kísérlet kudarcáról sem, hiszen amennyiben komolyan vesszük minden érték átértékelésének az életmű egészén végigvonuló szándékát, akkor újra meg újra vissza kell kanyarodnunk a folyamatos keletkezés és a metaforikus igazság korai müvekben kifejtett, egymással lényegileg összetartozó gondolataihoz. Ha azonban a hatalom akarása és az örök visszatérés dionüszoszi filozófiája szempontjából a fenti két belátás valóban konstitutív jelentőséggel bír, akkor elképzelhető, hogy az azokat inspiráló Kant-kritika vizsgálata nélkül a nietzschei gondolkodás rekonstrukciójára irányuló kísérletek eleve kudarcra volnának ítélve. Ahogyan Mihailo Durić fogalmaz, Nietzsche ,,alapvető gondolata a megfoghatatlanság peremén táncol”; ${ }^{518}$ a magunk

\footnotetext{
${ }^{518}$ Durić (1994) 69. o.
} 
részéről pedig azt gyanítjuk, hogy vele kapcsolatban eleve csak azoknak az értelmezési kísérleteknek lehet esélyük, melyek elegendő mozgásteret hagynak a számára; azoknak, amelyek Nietzschétől megtanulták, hogy végső szó nincs, csak első kérdés. 


\section{Függelék}

\section{KSA 7.575 / KGW III. 26[12]}

Bewegung in der Zeit

A $\quad$ B

Raumpunkt A wirkt auf Raumpunkt B und umgekehrt.

Dazu bedarf es einer Zeit, denn jede Wirkung hat einen Weg zurückzulegen.

Aufeinanderfolgende Zeitpunkte würden in einander fallen.

A trifft mit seiner Wirkung nicht mehr auf das B des ersten Momentes. Was heißt es nun: B existirt noch und ebenso A existirt noch, wenn sie sich treffen?

Das hieße vor [allem], A ist unverändert dasselbe in dem und jenem Zeitpunkte. Dann aber ist A keine wirkende Kraft, denn die kann nicht mehr dieselbe sein; denn das hieße, sie hätte nicht gewirkt.

Nehmen wir das Wirkende in der Zeit, so ist das in jedem kleinsten Zeitmomente Wirkende ein Verschiedenes.

Das heißt: die Zeit beweist das absolute Nichtbeharren einer Kraft.

Alle Raumgesetze sind also zeitlos gedacht, das heißt müssen gleichzeitig und sofort sein.

Die ganze Welt in einem Schlage. Dann aber giebt es keine Bewegung.

Die Bewegung laborirt an dem Widerspruch, daß sie nach Raumgesetzen construirt und durch Annahme einer Zeit wieder diese Gesetze unmöglich macht: d. h. zugleich ist und nicht ist.

Hier ist durch die Annahme zu helfen, daß entweder Zeit oder Raum $=0$ ist.

Nehme ich den Raum als unendlich klein, so werden alle Zwischenräume zwischen den Atomen unendlich klein, d. h. alle punktuellen Atome fallen zusammen in einen Punkt.

Da aber die Zeit unendlich theilbar ist, so ist die ganze Welt möglich rein als Zeitphänomen, 
weil ich jeden Zeitpunkt mit dem einen Raumpunkt besetzen kann, somit ihn unendliche Mal setzen kann. Man müßte sich somit als Wesen eines Körpers Zeitpunkte distinkt denken, d. h. den einen Punkt in bestimmten Zwischenräumen gesetzt. Zwischen jedem Zeitzwischenraum haben noch unendliche Zeitpunkte Platz: also könnte man sich eine ganze Körperwelt denken, alle aus einem Punkte bestritten, aber so, daß wir Körper in unterbrochene Zeitlinien auflösen.

Jetzt ist nur

ein reproduzirendes Wesen nöthig, welches frühere Zeitmomente neben den gegenwärtigen hält. Darin sind unsere Körper imaginirt.

Es giebt dann kein Nebeneinander, als in der Vorstellung.

Alles Nebeneinander wäre erschlossen und vorgestellt. Die Gesetze des Raumes wären sämmtlich construirt und verbürgten nicht das Dasein des Raumes. 
Die Zahl und die Art der Aufeinanderfolge jenes einen oft gesetzten Punktes macht dann den Körper aus.

Die Realität der Welt bestünde dann in einem verharrenden Punkte. Die Vielheit enstünde dadurch, daß es vorstellende Wesen gäbe, welche diesen Punkt in den kleinsten Zeitmomenten wiederholt dächten: Wesen, welche den Punkt auf verschiedenen Zeitpunkten als nicht identisch annehmen und jetzt diese Punkte gleichzeitig nehmen.

Übersetzung aller Bewegungsgesetze in Zeitproportionen.

Das Wesen der Empfindung bestünde darin, allmählich solche Zeitfiguren immer feiner zu empfinden und zu messen; die Vorstellung construirt sie als ein Nebeneinander und erklärt jetzt diesem Nebeneinander gemäß den Fortgang der Welt: reine Übertragung in eine andere Sprache, in die des Werdens.

Die Ordnung der Welt wäre die Regelmäßigkeit der Zeitfiguren: doch müßte man dann jedenfalls die Zeit mit einer constanten Kraft wirkend denken, nach Gesetzen, die wir uns nur aus dem Nebeneinander deuten können. Actio in distans temporis punctum.

An sich haben wir gar kein Mittel ein Zeitgesetz hinzustellen.

Wir hätten dann eine punktuelle Kraft, welche zu jedem späteren Zeitmomente ihrer Existenz eine Relation hätte, d. h. deren Kräfte in jenen Figuren und Relationen bestünden. In jedem kleinsten Moment müßte die Kraft verschieden sein: aber die Aufeinanderfolge wäre in irgendwelchen Proportionen und die vorhandene Welt bestünde in der Sichtbarwerdung dieser Kraft-Proportionen, d.h. Übersetzung ins Räumliche.

Gewöhnlich nimmt man in der atomistischen Physik in der Zeit unveränderliche Atom-Kräfte an, also őv $\tau \alpha$ im parmenideischen Sinne. Diese können aber nicht wirken.

Sondern nur absolut veränderliche Kräfte können wirken, solche die keinen Augenblick dieselben sind.

Alle Kräfte sind nur Funktion der Zeit.

1) Eine Wirkung von aufeinanderfolgenden Zeitmomenten ist unmöglich: denn zwei solche Zeitpunkte würden in einander fallen. Also ist jede Wirkung actio in distans, d. h. durch Springen. 
2) Wie eine Wirkung dieser Art in distans möglich ist, wissen wir gar nicht.

3) Schnell, langsam usw. in der ganzen Art dieser Wirkung. D. h. die Kräfte, als Funktionen der Zeit, äußern sich in den Relationen naher oder ferner Zeitpunkte, nämlich schnell oder langsam. Die Kraft liegt im Grade der Beschleunigung. Die allerhöchste Beschleunigung läge in der Wirkung eines Zeitmomentes auf das nächste, d. h. es wäre dann = unendlich groß.

Je größer die Langsamkeit, um so größer die Zwischenräume der Zeit, um so größer das distans.

Also Relation entfernter Zeitpunkte ist Langsamkeit: alle Langsamkeit ist natürlich relativ.

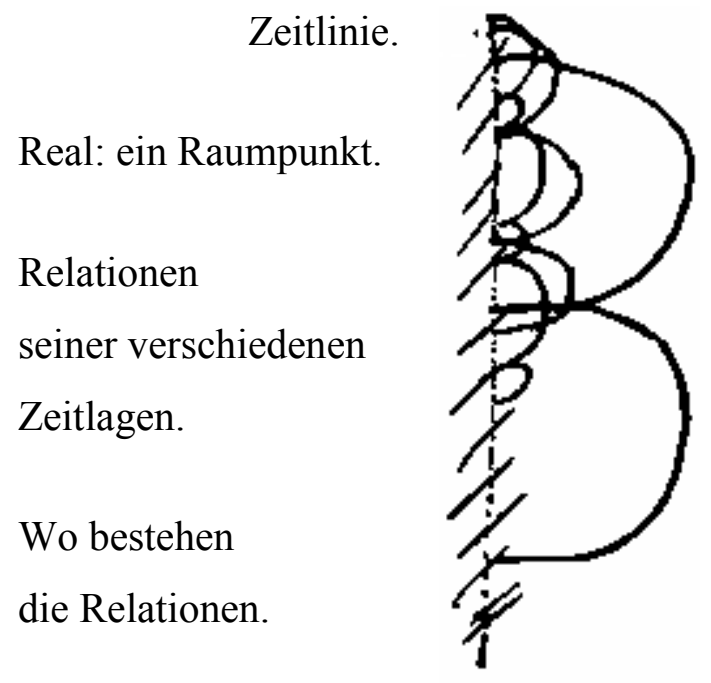

Keine Bewegung in der Zeit ist stetig.
Wir messen an etwas

Räumlichbleibendem

die Zeit und deshalb

setzen wir voraus,

daß zwischen

Zeitpunkt A und

Zeitpunkt B eine

stetige Zeit sei.

Die Zeit ist aber

gar kein continuum,

sondern es giebt nur

total verschiedene

Zeitpunkte, keine

Linie. Actio in distans.

Es ist nur von Zeitpunkten zu reden, nicht mehr von Zeit.

Der Zeitpunkt wirkt auf einen anderen Zeitpunkt, also dynamische Eigenschaften vorauszusetzen.

Zeitatomenlehre.

Es ist möglich, 1) die vorhandene Welt auf punktuelle Raumatomistik zurückzuführen,

2) diese wieder auf Zeitatomistik zurückzuführen,

3) die Zeitatomistik fällt endlich zusammen mit einer Empfindungslehre.

Der dynamische Zeitpunkt ist identisch mit dem Empfindungspunkt. Denn es giebt keine Gleichzeitigkeit der Empfindung. 


\section{Irodalomjegyzék}

\section{FRIEDRICH NIETZSCHE MÜVEI}

Nietzsche, Friedrich: Gesammelte Werke. Erster Band. Jugendschriften. 1858-1868. Musarion Verlag, München, 1922. (a továbbiakban MusA)

Nietzsche, Friedrich:Historisch-Kritische Gesammtsausgabe. Hg. Hans Joachim Mette, Karl Schlechta. C. H. Beck Verlag, München, 1934-40. (a továbbiakban BAW)

Nietzsche, Friedrich: Sämtliche Werke. Kritische Studienausgabe. Hg. Giorgio Colli, Mazzino Montinari. De Gruyter, Berlin - New York, 1982. (a továbbiakban KSA)

Nietzsche, Friedrich: Sämtliche Briefe. Kritische Studienausgabe. Hg. Giorgio Colli, Mazzino Montinari. De Gruyter, Berlin - New York, 1982. (a továbbiakban BVN)

A Nietzsche, Friedrich: Az Antikrisztus. Ford. Csejtei Dezső. Ictus, Szeged, 1993.

BA Nietzsche, Friedrich: Bálványok alkonya. Ford. Óvári Csaba. Attraktor, Máriabesnyő - Gödöllö, 2010.

DS Nietzsche, Friedrich: „David Strauss, a hitvalló és író.” In: Uő: Korszerütlen elmélkedések. Ford. Bognár Bulcsú, Csatár Péter. Atlantisz, Bp., 2004. 7-92. o.

EE Nietzsche, Friedrich: Emberi - túlságosan is emberi. Ford. Romhányi Török Gábor. Szukits, Szeged, 2000.

EH Nietzsche, Friedrich: Ecce homo. Ford. Horvath Géza. Göncöl, Bp., 2003.

FGTK Nietzsche, Friedrich: „Filozófia a görögök tragikus korszakában.” In:U. ő: Ifjúkori görög tárgyú írások. Vál. Tatár György, Ford. Molnár Anna. Európa, Bp., 1988.

H Nietzsche, Friedrich: Hajnalpirr: gondolatok a morális elöitéletekröl. Ford. Óvári Csaba. Attraktor, Máriabesnyő - Gödöllő, 2009.

HA Nietzsche, Friedrich: A hatalom akarása. Minden érték átértékelésének kisérlete. Ford. Romhányi Török Gábor. Cartaphilus, Bp., 2002. (a továbbiakban HA)

JR Nietzsche, Friedrich: Túl jón es rosszon. Egy eljövendö filozófia elöjátéka. Ford. Tatár György Ikon, Bp., 1995.

MG Nietzsche, Friedrich: A morál genealógiájához. Ford. Várhelyi Szabó László Comitatus, Veszprém, 1998.

NMIH Nietzsche, Friedrich: „A nem-morálisan fölfogott igazságról és hazugságról.” In: Athenaeum. 1992. I/3. A francia Nietzsche-recepció. 3-15. o. 
PE Nietzsche, Friedrich: Platón és elödei: elöadások és jegyzetek a görög filozófia kezdeteiről. Szerk. Hévizi Ottó. Ford. Kurdi Imre, Molnár Anna. Gond/Cura, Bp., 2007.

R Nietzsche, Friedrich: „Retorika.” Ford. XY In: Az irodalom elméletei. Szerk. Thomka Beáta Jelenkor, Pécs, 1997, 5-51. o.

RWB Nietzsche, Friedrich: „Richard Wagner Bayreuthban.” Ford. Zoltai Dénes In: Uo”: Korszerütlen elmélkedések. Ford. Bognár Bulcsú et al. Atlantisz, Bp., 2004. 93-177. o.

SN Nietzsche, Friedrich: „Schopenhauer mint nevelö.” Ford. Hidas Zoltán In: Uo”: Korszerütlen elmélkedések. Ford. Bognár Bulcsú et al. Atlantisz, Bp., 2004.179-265. o.

THK Nietzsche, Friedrich: „A történelem hasznáról es káráról.” Ford. Tatár György. In: Uő: Korszerütlen elmélkedések. Ford. Bognár Bulcsú et al. Atlantisz, Bp., 2004. 267-342. o.

TSZ Nietzsche, Friedrich: A tragédia születése avagy görögség és pesszimizmus. Ford. Kertész Imre. Európa, Bp., 1986.

ÚF Nietzsche, Friedrich: „Az új felvilágosodás”: jegyzetfüzetek az „Így szólott Zarathustra" keletkezésének idejéből. Ford. Kurdi Imre et al., szerk. Hévizi Ottó. Osiris, Bp.,2001.

VT Nietzsche, Friedrich: A vidám tudomány. Ford. Romhányi Török Gábor. Szukits, Szeged, 2003.

Z Nietzsche, Friedrich: Így szólott Zarathustra. Ford. Kurdi Imre. Osiris/Gond, Bp, 2001.

Nietzsche,Friedrich: „A szó és a zene”. Ford. Petra-Szabó Gizella. In: Kultusz és áldozat: a német esszé klasszikusai. Szerk. Salyámosy Miklós, ford. Bart István et al. Európa, Bp., 1981. 303-316. o.

Nietzsche, Friederich: Bálványok alkonya. Nietzsche kontra Wagner. Ford. Romhányi Török Gábor. Holnap, Bp., 2004.

Nietzsche, Friedrich: Ifjúkori görög tárgyú írások. Vál. Tatár György, ford. Molnár Anna. Európa, Bp., 1988.

Nietzsche, Friedrich: Müvelödési intézményeink jövőjéröl: hat nyilvános elöadás. Ford. Óvári Csaba. Attraktor, Máriabesnyő - Gödöllő, 2011.

Nietzsche, Friedrich: Válogatott levelei. 1861. január-1889. január. Ford., vál. Romhányi Török Gábor. Holnap, Bp., 2008.

Nietzsche, Friedrich: Versei. Ford. Csorba Győző et al., vál. Hajnal Gábor. Európa, Bp., 1989. 
Nietzsche, Friedrich: „Wagner esete. Zenészprobléma.” Ford. Romhányi Török Gábor. In: U. ő: Wagnerről és Schopenhauerről. Ford. Romhányi Török Gábor. Holnap, Bp., 2001. 7-42. o.

\section{FORRÁSOK}

Hegel, G. W. F.:A szellem fenomenológiája. Ford. Szemere Samu. Akadémiai Kiadó, Bp., 1973.

Heidegger, Martin: Identität und Differenz. Neske, Pfullingen, 1978.

Heidegger, Martin: Identity and Difference. Trans. Joan Stambaugh. Harper \& Row, New York - Evanston - London, 1969.

Heidegger, Martin: A metafizika alapfogalmai. Ford. Aradi László, Olay Csaba. Osiris, Bp., 2004.

Heidegger, Martin: „Bevezetés a »Mi a metafiziká?«-hoz.” Ford. Vajda Mihály. In: U. ő: „,...költöien lakozik az ember...” Válogatott irások. Szerk. Pongrácz Tibor, ford. Bacsó Béla et al. T-Twins - Pompei, Budapest - Szeged, 1994a, 171-190. o.

Heidegger, Martin: Kant és a metafizika problémája. Ford. Ábrahám Zoltán, Menyes Csaba. Osiris - Gond, Bp., 2000.

Heidegger, Martin: „... költőien lakozik az ember ...”Válogatott irások. Szerk. Pongrácz Tibor, Ford. Bacsó Béla et al. T-Twins - Pompeji, Budapest - Szeged, 1994.

Heidegger, Martin: Lét és idö. Ford. Vajda Mihály et al. Osiris, Bp, 2001. (a továbbiakban LI)

Heidegger, Martin: „Mi a metafizika?” Ford. Vajda Mihály. In: U. ő: „,...költőien lakozik az ember..."Válogatott irások. Szerk. Pongrácz Tibor, ford. Bacsó Béla et al. T-Twins Pompei, Budapest - Szeged, 1994b, 13-34. o.

Heidegger, Martin: Nietzsche. I-II. Neske, Pfullingen, 1961. (a továbbiakban NI)

Heidegger, Martin: Nietzsche. Volumes One and Two. Trans. David Farrell Krell. Harper \& Row, San Francisco, 1991.

Heidegger, Martin: Nietzsche. Volumes Three and Four. Trans. David Farrell Krell. Harper \& Row, San Francisco, 1991.

Heidegger, Martin: „Nietzsche metafizikája.” Ford. Sarankó Márta. In: EX Symposion. 1994d. Nietzsche-különszám. 42-54. o. 
Heidegger, Martin: „Nietzsche mondása: »Isten halott«.” Ford. Czeglédi András. In: U. ő: Rejtekutak. Ford. Ábrahám Zoltán et al. Osiris, Bp., 2006, 183-232. o.

Heidegger, Martin: Rejtekutak. Ford. Ábrahám Zoltán et al. Osiris, Bp., 2006.

Heidegger, Martin: „Utószó a »Mi a metafiziká?«-hoz.” Ford. Vajda Mihály. In: U. ő: „,...költőien lakozik az ember...” Válogatott írások. Szerk. Pongrácz Tibor, ford. Bacsó Béla et al. T-Twins - Pompei, Budapest - Szeged, 1994c, 105-116. o.

Kant, Immanuel: A tiszta ész kritikája. Ford. Kis János. Ictus, Szeged, 1996. (a továbbiakban TÉK)

Spinoza, Benedictus de: Etika. Ford. Szemere Samu. Osiris, Bp., 1997.

\section{FELHASZNÁLT IRODALOM}

Abel, Günter - Salaquarda, Jörg (eds.): Krisis der Metaphysik. De Gruyter, New-YorkBerlin, 1989.

Alföld, 1997/12.

Allison, David B.: „Recipes for Ruin.” In: International Studies in Philosophy. XXIII/2, pp. $35-54$.

Andersen, Joshua: „Truth and Illusion beyond Falsification: Re reading On Truth and Lie in the Extra Moral Sense.” In: Nietzsche-Studien 39. De Gruyter, Berlin - New York, 2010. pp. 255-281.

Andreas-Salomé, Lou: Nietzsche in seinen Werken. Insel Verlag, 1983.

Andreas-Salomé, Lou: „Visszaemlékezés.” Ford. Schleicher Dóra. In: EX Symposion. 1994. Nietzsche-különszám. 156-160. o.

Ansell-Pearson, Keith (ed.): Nietzsche and Modern German Thought. Routledge, LondonNew York, 1991.

Ansell-Pearson, Keith: „Nietzsche's Brave New World of Force Thoughts on Nietzsche's $1873 »$ Time Atom Theory« Fragment \& on the Influence of Boscovich on Nietzsche." In: Pli. The Warwick Journal of Philosophy. Vol. 9. 2000, pp. 6-35.

Artaud, Antonin: A könyörtelen színház. Ford. Betlen János. Gondolat, Bp., 1985.

Athenaeum,1992. I/3. A francia Nietzsche-recepció.

Babich, Babette (ed.): Heidegger \& Nietzsche. Rodopi, Amsterdam-New York, 2012. 
Bacsó Béla: „Mert nem mi tudunk...” Filozófiai és müvészetelméleti írások. Kijárat, Bp., 1999.

Bacsó Béla (szerk.): Szöveg és interpretáció. Cserépfalvi, Bp., 1991.

Bataille, Georges: „Nietzsche és a tilalmak áthágása.” Ford. Somlyó György. In: Athenaeum. 1992. I/3. A francia Nietzsche-recepció. 42-55. o.

Biczó Gábor: „A morál és az igazság »halála«.” In: Gond. 1999/18-19. 322-337. o. Online: http://www.c3.hu/ gond/tartalom/18-19/frabiczo.html

Biczó Gábor: A tragédia délelöttje. Az ifjú Nietzsche filozófiai perspektivizmusa. Osiris, Bp., 2000.

Biczó Gábor: „A »történeti lét« időstruktúrája Nietzsche korai bölcseletében.” In: Európa Nietzsche után. [Konferenciakötet, 2005] Online: http://filozofia.ektf.hu/koteteink/2005.html

Blanchot, Maurice: „Nietzsche és a töredékes írás” Ford. Ádám Anikó. In: Athenaeum. 1992. I/3. A francia Nietzsche-recepció. 56-77.o.

Blondel, Eric: „The Question of Genealogy.” In: Nietzsche, Genealogy, Morality. Essays On Nietzsche's „On The Genealogy of Morals”. Ed. Richard Schacht. California UP, BerkleyCalifornia, 1994, pp. 306-317.

Bolaños, Paolo: „Nietzsche, Spinoza, and the Ethological Conception of Ethics.” In: Minerva - An Internet Journal of Philosophy. Vol. 11. 2007. Online: http://www.minerva.mic.ul.ie/vol11/Deleuze.html

Boros Gábor (szerk.):Ész és szenvedély. Filozófiai tanulmányok a XVII-XVIII. századról. Ford. Barcza Katalin et al. Áron, Bp., 2002.

Boros Gábor: Spinoza és a filozófiai etika problémája. Atlantisz, Bp., 1997.

Boscovich, Roger Joseph: A Theory of Natural Philosophy. Trans. J. M. Child. Open Court Publishing Company, Chicago-London, 1922.

Brandenstein Béla: Nietzsche. Szent István Társulat, Bp., 2002.

Brezeale, Daniel: „Ecce Psycho: Remarks on the Case of Nietzsche.” In: International Studies in Philosophy. XXIII/2, pp. 19-33.

Breazeale, Daniel: „Nietzsche: The Untimely Meditations.” In: Introductions to Nietzsche. Ed. Robert B. Pippin. Cambridge, UP, 2002. pp. 67-90.

Brobjer, Thomas H.: „The Place and Role of »Der Antichrist« in Nietzsche's Four Volume Project »Umwerthung aller Werthe«.” In: Nietzsche-Studien 40. De Gruyter, Berlin, 2011. s. 262-273.

Bujalos István (szerk.): A posztmodern állapot. Jürgen Habermas, Jean-François Lyotard, Richard Rorty tanulmányai. Ford. Angyalosi Gergely et al. Századvég - Gond, Bp., 1993. 
Burnham, Douglas: Reading Nietzsche. An Analysis of „Beyond Good and Evil”. Acumen Publishing Ltd, Stocksfield, 2007.

Caputo, John D.: Against Ethics: Contributions to a Poetics of Obligation with Constant Reference to Deconstruction. Indiana UP, Bloomington, 1993.

Cassirer, Ernst: Kant élete és müvei. Ford. Mesterházi Miklós. Osiris, Bp., 2001.

Cassirer, Ernst: „Kant és a metafizika problémája. Megjegyzések Martin Heidegger Kantinterpretációjához.” Ford. XY In: Heidegger, Martin: Kant és a metafizika problémája. Ford. Ábrahám Zoltán, Menyes Csaba. Osiris - Gond, Bp., 2000, 362-400. o.

Cassirer, Ernst: Substanzbegriff und Funktionsbegriff: Untersuchungen über die Grundfragen der Erkenntniskritik. Cassirer, Berlin, 1923.

Caygill, Howard:„Affirmation and eternal return in the Free-Spirit Trilogy.” In: Nietzsche and Modern German Thought. Ed. Keith Ansell-Pearson. Routledge, London-New York, 1991, pp. 216-239.

Chitas, Eduardo - Losurdo, Domenico (hg.): Abstrakt und Konkret- Zwei Schlüsselkategorien des zeitgenössischen Denkens. Peter Lang, Frankfurt am Main/Wien, 2000.

Clark, Maudemarie - Leiter, Brian: „Nietzsche: Daybreak.” In: Introductions to Nietzsche. Ed. Robert R. Pippin. Cambridge, Cambridge UP, 2002, pp. 112-136.

Clark, Maudemarie: Nietzsche on Truth and Philosophy. Cambridge UP, Cambridge, 1990.

Crawford, Claudia: „Nietzsche's Overhuman: Creating on the Crest of the Timepoint.” In: Journal of Nietzsche Studies. Vol. 30. 2005, pp. 22-48.

Crawford, Claudia: The Beginnings of Nietzsche's Theory of Language. De Gruyter, Berlin, 1988.

Czeglédi András: „Egy »antinihilista« kísérlet hatása egy másikra.” In: Határ 4 (1995), 93124. o.

Czeglédi András (et al.): Ész, természet, történelem. Filozófiai tanulmányok. Áron, Bp., 2002.

Danto, Arthur C.: Nietzsche as Philosopher. Columbia UP, New York, 2005.

Danto, Arthur C.: „Some Remarks on The Genealogy of Morals.” In: Nietzsche, Genealogy, Morality. Essays On Nietzsche's „On The Genealogy of Morals”. Ed. Richard Schacht. California UP, Berkley, 1994, pp. 35-48.

Deleuze, Gilles: Abécédaire. (Interjú, rend. Pierre-André Boutang) Az általunk hivatkozott interjú-részlet helye: https://www.youtube.com/watch? $\mathrm{v}=\mathrm{mHYrxP-0 \textrm {ksU }}$, a szöveg angol fordítása online: https://terenceblake.wordpress.com/2013/08/17/english-transcript-ofdeleuze-on-joy/ 
Deleuze, Gilles: Difference and Repetition. Trans. Paul Patton. Columbia UP, New York, 1994.

Deleuze, Gilles - Guattari, Felix: „Mi a filozófia?” Ford. Pörczi Zsuzsanna, Takács Ádám. In: Nappali Ház. 1993/4. 59-65. o.

Deleuze, Gilles: Nietzsche és a filozófia. Ford. Moldvay Tamás. Gond - Holnap, Bp., 1999.

Deleuze, Gilles: Spinoza és a kifejezés problémája. Ford. Moldvay Tamás. Osiris - Gond, Bp., 2000.

De Man, Paul: „A trópusok retorikája. [Nietzsche.]” Ford. Vástyán Rita. In: Helikon. 1994/12. 36-47. o.

Derrida, Jacques: A hang és a fenomén. A jel problémája Husserl fenomenológiájában. Ford. Seregi Tamás. Kijárat, Bp., 2013.

Derrida, Jacques: „A filozófiában újabban meghonosodott apokaliptikus hangnemről.” Ford. Angyalosi Gergely. In: Jacques Derrida - Immanuel Kant: Minden dolgok vége. Ford. Angyalosi Gergely et al. Századvég, Bp., 1993, 34-93. o.

Derrida, Jacques: A kegyetlenség színháza. Paule Thévenin-nek. Ford. Farkas Anikó, Ivacs Anikó, et al. Online: http://www.literatura.hu/szinhaz/derrida.htm

Derrida, Jacques: „A struktúra, a jel és a játék az embertudományok diskurzusában.” Ford. Gyimesi Tímea. In: Helikon. 1994/1-2. 21-34. o.

Derrida, Jacques: „Az el-különböződés.” Ford. Gyimesi Tímea. In: Szöveg és interpretáció. Szerk. Bacsó Béla. Cserépfalvi, Bp., 1991, 43-63. o.

Derrida, Jacques: „Èperons. Nietzsche stílusai.” Ford. Sajó Sándor. In: Athenaeum, 1992. I/3. A francia Nietzsche-recepció. 172-213. o.

Derrida, Jacques: „Írásra vagyok ítélve.” Ford. Orbán Jolán. In: Jelenkor, 2005/10. 957-961. o.

Derrida, Jacques: „Két kérdés aláírásokat értelmezve. (Nietzsche/Heidegger)” Ford. Somlyó Bálint, Szücs Tamás. In: Literatura, 1991/4. 322-335. o.

Derrida, Jacques - Kant, Immanuel: Minden dolgok vége. Ford. Angyalosi Gergely et al. Századvég, Bp., 1993.

Durić, Mihailo: „Nietzsche filozófiaművészete.” Ford. XY In: EX-Symposion, 1994. Nietzsche-különszám. 63-71. o.

Európa Nietzsche után.[Konferenciakötet, Online: http://filozofia.ektf.hu/koteteink/2005.html

Ex-Symposion, 1994. Nietzsche-különszám. 
Filozófiai Figyelö, 1986/I.

Foucault, Michel: A fantasztikus könyvtár. Ford. Romhányi Török Gábor. Pallas-Attraktor, Bp., 1998.

Gadamer, Hans-Georg: „Dekonstrukció és hermeneutika.” Ford. XY In: Alföld, 1997/12. 1741. o. Online: http://epa.oszk.hu/00000/00002/00024/gadamer.html

Gadamer, Hans-Georg: Igazság és módszer. Ford. Bonyhai Gábor. Osiris, Bp., 2003.

Gadamer, Hans-Georg: „Szöveg és interpretáció.” Ford. Hévizi Ottó. In: Szöveg és interpretáció. (szerk.: Bacsó Béla) Cserépfalvi, Bp., 1991, 17-41. o.

Gadamer, Hans-Georg: „Zarathustra drámája.” Ford. Biczó Gábor. In: Gond, 1999/23-24. 720. o. Online: http://www.c3.hu/ gond/tartalom/23-24/fragadam.html

Gerhardt, Volker: Die Moral des Immoralismus. Nietzsches Beitrag zu einer grundlegung der Ethik." In: Krisis der Metaphysik. Ed. Günter Abel, Jörg Salaquarda. De Gruyter, NewYork-Berlin, 1989. s. 417-447.

Geuss, Raymond: „Nietzsche: The Birth of Tragedy.” In: Introductions to Nietzsche. Ed. Robert B. Pippin. Cambridge UP, Cambridge, 2002. pp. 44-66.

Gillespie, Michael Allen:,Nietzsche and the anthropology of nihilism.” In: Nietzsche-Studien 28. 1999, pp. 141-155.

Gond, 1999/18-19., illetve 1999/23-24.

Gori, Pietro: „Boscovich's »philosophical meditations" in the history of contemporary thought.” In: Proc. Conferencence „Ruggiero Boscovich: astronomer, man of science and culture since 300 years from the birth". Ed. Giuseppe Pareschi. Memorie della Società Astronomica Italiana Supplementi. 2012. Vol. 75., pp. 282-292.

Green, Michael Steven: „Eternal recurrence in a Neo-Kantian context.” In: Kriterion, Vol. 54. No. 128. (2013) Online: $\quad$ http://www.scielo.br/scielo.php?pid=S0100$\underline{512 X 2013000200011 \& \text { script }=\text { sci arttext }}$

Green, Michael Steven: Nietzsche and the Transcendental Tradition. Illinois UP, UrbanaChicago, 2002.

Hanshe, Rainer J. (comp.): Nietzsche's Library. Online: http://www.nietzschecircle.com/Pdf/NIETZSCHE_S_LIBRARY.pdf

Helikon, 1994/1-2.

Heller Ágnes: „Mit számít, kinek beszél?” In: Gond, 1999/23-24. 158-171. o. Online: http://www.c3.hu/ gond/tartalom/23-24/fraheller.html

Himmelmann, Beatrix (hg.): Kant und Nietzsche im Wiederstreit. De Gruyter, Berlin, 2005. 
Hodge, Joanna: Derrida on Time. Routledge, New York, 2007.

Hollingdale, J. R.: „Rövid Nietzsche-életrajz.” Ford. XY In: EX-Symposion, 1994. Nietzschekülönszám. 2-9. o.

Holmi, 2004/10.

Horstmann, Rolf-Peter: „Nietzsche: Beyond Good and Evil.” In: Introductions to Nietzsche. Ed. Robert R. Pippin. Cambridge UP, Cambridge, 2002. pp. 178-198.

International Studies in Philosophy, Volume 23, Issue 2, 1991.

Janaway, Christopher: „Nietzsche, the self, and Schopenhauer.” In: Nietzsche and Modern German Thought. Ed. Keith Ansell-Pearson. Routledge, London - New York, 1991, pp. 119142.

Jaspers, Karl: Nietzsche: Einführung in das Verständnis seines Philosophierens. De Gruyter, Berlin - Leipzig, 1974.

Jelenkor,2005/10.

Journal of the History of Ideas, Vol. 9, No. 4. Oct. 1948.

Journal of Nietzsche Studies, Vol. 30. 2005.

Kant, Immanuel: „A filozófiában újabban meghonosodott előkelő hangnemről.” Ford. Nyizsnyánszki Ferenc. In: Derrida, Jacques - Kant, Immanuel: Minden dolgok vége. Ford. Angyalosi Gergely et al. Századvég, Bp., 1993.

Kant, Immanuel: „A fordulat levele (1972).” Ford. Vidrányi Katalin. In: Világosság. 2004/6. 7-10. o.

Kaufmann, Walter: „Nietzsche's Admiration of Socrates.” In: Journal of the History of Ideas. Vol. 9, No. 4. Oct. 1948.

Kinlaw, Jeffery: „Heidegger on Nietzsche's Word and Overcoming Ontotheology.” In: Heidegger \& Nietzsche. Ed. Babette Babich et al. Rodopi, Amsterdam-New York, 2012. pp. 59-76.

Klossowski, Pierre: „Nietzsche, a sokistenhit és a paródia.” Ford. Szántó F. István. In: Athenaeum. 1992. I/3. A francia Nietzsche-recepció. 78-104. o.

Kofman, Sarah: „Bevezető az Ecce homo olvasásához” Ford. Somlyó Bálint. In: Athenaeum, 1992 I/3. A francia Nietzsche-recepció. 214-241.o.

Köhler, Joachim: Friedrich Nietzsche és Cosima Wagner: az alávetettség iskolája. Ford. Romhányi Török Gábor. Holnap Kiadó, Budapest, 2005.

Kriterion, Vol. 54. No. 128. (2013) 
Kunszt György: Nihil és ámen. (Nietzsche-reflexiók.) Gond/Palatinus, Bp., 2002.

Lacoue-Labarthe, Philippe: „Történelem és mimézis.” Ford. Betegh Gábor. In: Athenaeum, 1992 I/3. A francia Nietzsche-recepció. 242-264. o.

Land, Nick: „Art as insurrection: the question of aesthetics in Kant, Schopenhauer, and Nietzsche." In: Nietzsche and Modern German Thought. Ed. Keith Ansell-Pearson. Routledge, London-New York, 2002. pp. 240-256.

Lange, F. A.:Geschichte des Materialismus und Kritik seiner Bedeutung in der Gegenwart. (1866) Neudruck in 2 Bänden: Suhrkamp, Frankfurt am Main, 1974.

Leibniz, G. W.: „Monadológia.” In: U. ő: Válogatott filozófiai irásai. Ford. Endreffy Zoltán et al. Európa, Bp., 1986.

Lessing, Theodor: African Spir's Erkenntnislehre. Münchow, Giessen, 1900.

Literatura, 1991/4.

Lord, Beth: „Deleuze and Kant.” In: The Cambridge Companion to Deleuze. Ed. Daniel W. Smith, Henry Somers-Hall. Cambridge UP, New York, 2012, pp. 82-101.

Lyotard, Jean-François: „A posztmodern állapot.” Ford. Bujalos István - Orosz László. In: A posztmodern állapot. Jürgen Habermas, Jean-François Lyotard, Richard Rorty tanulmányai. Szerk. Bujalos István, ford. Angyalosi Gergely et al. Századvég/Gond, Bp., 1993, 7-145. o.

Magnus, Bernd - Higgins, Kathleen M. (eds.): The Cambridge Companion to Nietzsche. Cambridge UP, Cambridge, 1996.

May, Simon: On the Genealogy of Morality. A Critical Guide. Cambridge UP, Cambridge, 2011.

May, Simon: „Why Nietzsche is still in the morality game." In: On the Genealogy of Morality. A Critical Guide. Ed. Simon May. Cambridge UP, Cambridge, 2011. pp. 78-100.

Minerva - An Internet Journal of Philosophy, Vol. 11. 2007. Online: http://www.minerva.mic.ul.ie/vol11/index.html

Montinari, Mazzino: „Nietzsche hagyatéka 1885-től 1888-ig avagy a szövegkritika és A hatalom akarása.” Ford. Kiss Endre. In: Filozófiai Figyelő, 1986/I. 94-113. o.

Montinari, Mazzino: Nietzsche lesen. De Gruyter, Berlin-New York, 1982. $\rightarrow$ TSZi letét

Moore, Gregory: Nietzsche, Biology and Metaphor. Cambridge UP, Cambridge, 2004.

Moreau, Pierre-Francois: „A spinozizmus mint szenvedélyek politikája.” Ford. Boros Gábor. In: Ész és szenvedély. Filozófiai tanulmányok a XVII-XVIII. századról. Ford. Barcza Katalin et al. Áron, Bp., 2002. 189-200. o

Nappali Ház, 1993/4. 
Negri, Antonio: The Savage Anomaly. The Power of Spinoza's Metaphysics and Politics. Trans. Michael Hardt. Minnesota UP, Minneapolis-Oxford, 1991.

Nehamas, Alexander: Nietzsche: Life as Literature. Harvard UP, Cambridge-Massachusets, 1985.

Nehamas, Alexander: „Nietzsche: Writings from the early notebooks.” In: Introductions to Nietzsche. Ed. Robert B. Pippin. Cambridge, UP, 2002, pp. 17-43.

Nietzsche-Studien 2., 25., 26., 28., 38., 39., 40.

Pareschi, Giuseppe (ed.): Proc. Conferencence „Ruggiero Boscovich: astronomer, man of science and culture since 300 years from the birth". Memorie della Società Astronomica Italiana Supplementi. 2012. Vol. 75.

Patton, Paul (ed.): Between Deleuze and Derrida. Continuum International Publishing, 2003.

Pippin, Robert B. (ed.): Introductions to Nietzsche. Cambridge, UP, 2002.

Pippin, Robert B.: „Morality as Psychology, Psychology as Morality: Nietzsche, Eros, and Clumsy Lovers." In: Nietzsche's Post-Moralism. Essays on Nietzsche's Prelude to Philosophy's Future. Ed. Richard Schacht. Cambridge, UP, 2001, pp. 79-99.

Pli. The Warwick Journal of Philosophy, Vol. 9. 2000.

Plótinosz:Az Egyröl, a szellemröl és a lélekröl - válogatott írások. Ford. Horváth Judit, Perczel István. Európa, Bp., 1986.

Popper, Karl R.:Conjectures and refutations. The Growth of Scientific Knowledge. Basic Books, New York - London, 1962.

Popper, Karl R.:Realism and the Aim of Science. Routledge, London - New York, 1992.

Popper, Karl R.:The Logic of Scientific Discovery. Routledge, London - New York, 2002.

Popper, Karl R.:The Myth of the framework. Routledge, London, 1994.

Psychiatria Hungarica, 2012/6. 27. évf.

Ricoeur, Paul: Fenomenológia és hermeneutika. Ford. Mezei Balázs. Kossuth, Bp., 1997.

Safranski, Rüdiger: Nietzsche. Szellemi életrajz. Ford. Györffy Miklós. Európa, Bp., 2002.

Salaquarda, Jörg: „Der Antichrist.” In: Nietzsche-Studien 2. De Gruyter, Berlin, 1973, s. 91136.

Salyámosy Miklós (szerk.): Kultusz és áldozat: a német esszé klasszikusai. Ford. Bart István et al. Európa, Bp., 1981.

Schacht, Richard: Nietzsche. Routledge, London-New York, 1983. 
Schacht, Richard: „Nietzsche: Human, All Too Human.” In: Introductions to Nietzsche. Ed. Robert R. Pippin. Cambridge UP, Cambridge, 2002, pp. 91-111.

Schacht, Richard (ed.): Nietzsche's Post-Moralism. Essays on Nietzsche's Prelude to Philosophy's Future. Cambridge, UP, 2001.

Schlechta, Karl - Anders, Anni: Friedrich Nietzsche: Von den verborgenen Anfängen seines Philosophierens. F. Frommann, Stuttgart-Bad Cannstatt, 1962

Schreiner Dénes: „A müvészet szerepe Nietzsche kultúrkritikájában” In: Czeglédi András et al.: Ész, természet, történelem. Filozófiai tanulmányok. Áron, Bp., 2004. 77-107.o.

Schröder, Winfired: Moralischer Nihilismus. Radikale Moralkritik von den Sophisten bis Nietzsche. Reclam, Stuttgart, 2005.

Shapiro, Gary: „Fesztivál, karnevál és paródia a Zarathustra negyedik könyvében.” Ford. Kis Gábor. In: Gond, 1999/23-24. 172-189. o. Online: http://www.c3.hu/ gond/tartalom/2324/frashapiro.html

Sherover, Charles M.: Heidegger, Kant and Time. Indiana UP, Bloomington-London, 1971.

Schrift, Alan D.: „Nietzsche's French legacy.” In: The Cambridge Companion to Nietzsche. Ed. Bernd Magnus, Kathleen M. Higgins. Cambridge UP, Cambridge, 1996, pp. 323-355.

Simon, Josef: „Welt auf Zeit. Nietzsches Denken in der Spannung zwischen der Absolutheit des Individuums und dem kategorialem Schema der Metaphysik." In: Krisis der Metaphysik. Ed. Günter Abel, Jörg Salaquarda. De Gruyter, New York - Berlin, 1989, s. 109-133.

Smith, Daniel W.: „Deleuze and Derrida, Immanence and Transcendence: Two Directions in Recent French Thought." In: Between Deleuze and Derrida. Ed. Paul Patton, John Protevi. Continuum International Publishing, 2003, pp. 47-63.

Smith, Daniel W. (ed.): The Cambridge Companion to Deleuze. Cambridge UP, New York, 2012 .

Sommer, Andreas Urs: „Sieben Thesen zur Geschichtsphilosophie bei Kant und Nietzsche.” In: Kant und Nietzsche im Wiederstreit. Hg. Beatrix Himmelmann. De Gruyter, Berlin, 2005. 217-242.

Soromenho-Marques, Viriato:,Ontological Nihilism. How Hegel was read by Nietzsche.” In: Abstrakt und Konkret - Zwei Schlüsselkategorien des zeitgenössischen Denkens. Hg. Eduardo Chitas, Domenico Losurdo. Peter Lang, Frankfurt am Main/Wien, 2000, s. 141-148.

Spir, Afrikan: Denken und Wirklichkeit: Versuch einer Erneuerung der kritischen Philosophie. J. G. Findel, Leipzig, 1873.

Stack, Gregory J.:Lange and Nietzsche. De Gruyter, New York, 1983. 
Stambaugh, Joan: „Introduction.” In: Heidegger, Martin: Identity and Difference. Trans. Joan Stambaugh. Harper \& Row, New York-Evanston-London, 1969. pp. 8-18.

Stambaugh, Joan: The Problem of Time in Nietzsche. Trans. John F. Humphrey. Bucknell UP, Lewisburg, 1987

Tatár György: Az öröklét gyürüje. Gondolat, Bp., 1989.

Tényi Tamás: Nietzsche és a pszichológia. Pécs, PTE, 2007.

Tényi Tamás: „The madness of Dionysus -- six hypotheses on the illness of Nietzsche.” In: Psychiatria Hungarica, 2012/6. 27. évf. 420-425. o.

Thomka Beáta (szerk.): Az irodalom elméletei. Jelenkor, Pécs, 1997.

Ullmann Tamás: „Az örök visszatérés imperatívusza.” In: Holmi, 2004/10. 1275-1286. o.

Valadier, Paul: „Dionüszoszt a Megfeszítettel szemben.” Ford. F. Zs. In: EX Symposion, 1994. Nietzsche-különszám. 139-145. o.

Vattimo, Gianni: The Adventure of Difference. Philosophy after Nietzsche and Heidegger. Johns Hopkins UP, Baltimore, 1993.

Venturelli, Aldo: Kunst, Wissenschaft und Geschichte bei Nietzsche. De Gruyter, Berlin, 2003.

Világosság, 2004/6.

Whitlock, Greg: „Examining Nietzsche's »time atom theory« fragment from 1873.” In: Nietzsche Studien 26. De Gruyter, 1997. pp. 350-360.

Whitlock, Greg: „Roger Boscovich, Benedict de Spinoza and Friedrich Nietzsche: the untold story.” In: Nietzsche-Studien 25. s. 200-220.

Williams, Robert R.: In: Tragedy, Recognition, and the Death of God. Studies in Hegel and Nietzsche. Oxford, UP, 2012.

Winteler, Reto: „Nietzsches Antichrist als (ganze) Umwerthung aller Werthe. Bemerkungen zum »Scheitern« eines »Hauptwerks«.” In: Nietzsche-Studien 38. De Gruyter, Berlin, 2009, 229-245.

Wyschogrod, Edith: Saints and Postmodernism: Revisioning Moral Philosophy. Chicago UP, Chicago-London, 1990. 